
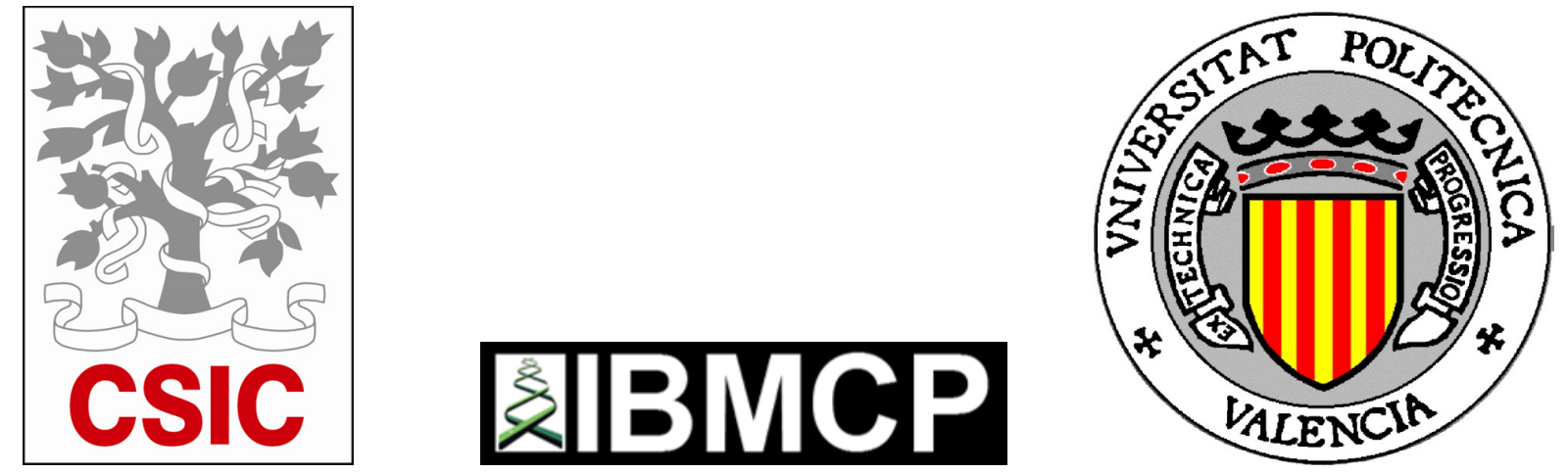

Relación entre el silenciamiento de RNA y la patogénesis inducida por un viroide con replicación nuclear

Memoria presentada por

GERMÁN EUGENIO MARTÍNEZ ARIAS

para optar al grado de

DOCTOR EN BIOTECNOLOGÍA

Directores

Profesor VICENTE PALLÁS BENET

Doctor GUSTAVO GERMÁN GÓMEZ

Julio 2011 

Don Vicente Pallás Benet, Doctor en Ciencias Biológicas, Profesor de Investigación del Consejo Superior de Investigaciones Científicas en el Instituto de Biología Molecular y Celular de Plantas (Universidad Politécnica de Valencia-Consejo Superior de Investigaciones Científicas) de Valencia.

Don Gustavo Germán Gómez, Doctor en Genética, Investigador Postdoctoral en el Instituto de Biología Molecular y Celular de Plantas (Universidad Politécnica de Valencia-Consejo Superior de Investigaciones Científicas) de Valencia.

CERTIFICAN: que Don Germán Eugenio Martínez Arias, Ingeniero Agrónomo por la Universidad Politécnica de Valencia, ha realizado bajo su dirección el trabajo que con título "Relación entre el silenciamiento de RNA y la patogénesis inducida por un viroide con replicación nuclear" presenta para optar al grado de Doctor en Biotecnología.

Y para que así conste y produzca los efectos oportunos donde proceda, firman el presente certificado en Valencia, a de Julio de 2011. 



\section{Agradecimientos}

Se atribuye a Cervantes el refrán: "de bien nacido es ser agradecido". Como pretendo ser un bien nacido, me siento en la obligación de agradecer la participación en esta tesis doctoral de un gran número (relativo) de personas.

En primer lugar tengo que, y quiero, agradecer a Vicente Pallás y a Gustavo Gómez el darme la oportunidad de poder realizar la tesis doctoral en su laboratorio. La tesis no es un camino fácil, ni muchas veces es el trabajo con el mejor horario o sueldo, pero es un camino por cuyo tránsito creo que he aprendido algunas cosas y gran parte de la culpa la tienen ellos.

Una parte de estos agradecimientos tan importante como para Vicente y Gustavo va para mis compañeros de laboratorio. Desde los postdoctorales Fede, Jesus, Toni y Mari Carmen, pasando por los predoctorales Ainhoa (ya post), Ana y Marta, hasta las técnicos de laboratorio Lorena Corachan y Lorena Latorre, todos han sido una parte muy importante de este trabajo. Hemos pasado más buenos que malos momentos juntos, (además de muchas horas... la mayor parte de estos 5 años) dentro y fuera del laboratorio. Voy a echar de menos todos esos momentos en cuanto cruce el charco.

No menos importante es la participación en esta tesis doctoral de Cesar Llave y de Livia Donaire. Gracias a ellos se han podido llevar a cabo los capítulos III, IV y V de la presente tesis. Solo esto sirve como ejemplo de la importante colaboración que hemos mantenido. Pero seguramente, estos capítulos son la parte menos importante de la colaboración dado que conocerles, valorar la tremenda humildad de los dos y poder ampliar mi mente como proyecto de investigador en su laboratorio ha sido una experiencia invaluable. La estancia en su laboratorio del CIB en Madrid ha sido una de los mejores momentos de esta tesis. Además al resto de integrantes del grupo: Fran, Fátima, Alberto, Meme, Anita, Gema y Llucia, así como a Paco Tenllado, les tengo un gran aprecio por el maravilloso tiempo que pasé con ellos.

La otra gran parte de los agradecimientos va para los "sufridores en silencio", esto es, mi familia. Sin mis padres que me han enseñado el incalculable valor del esfuerzo y el trabajo y que siempre me han apoyado y animado en este periodo doctoral, estoy seguro de que esta tesis habría sido mucho más costosa de terminar. Mis hermanas Elena y Clara, a las que he visto encauzar sus caminos (al menos educativos) durante este tiempo, son también una parte muy importante de los agradecimientos. Es reconfortante llegar a casa creyéndose uno un investigador (creyendo que le salen rayos de las orejas, como decía Jaime Sabines) y encontrarse con que uno solo es un peatón ... y gracias.

También parte del agradecimiento de ese descenso a lo mundano se lo debo a mis amigos. A Vicente, al cual conozco desde hace 27 años (¿tanto?), a Carol, Javi, Isidro, Eva, Sttef, Fernando, Israel, Daniel y Marco, os debo mucho más de lo que podéis creer (y no solo económicamente).

A medio camino entre los amigos y los compañeros de trabajo se encuentran mis compañeros del IBMCP a los cuales les debo (seguro que también dinero) pero además un gran agradecimiento. En ellos he encontrado además de similares motivaciones, las mismas ganas e ilusión por aprender, la mirada del naufrago como decía Ortega y Gasset: Javi, Ricardo, Jorge, Mari Ángeles y Patricia. 
A la gente de los laboratorios de Ricardo Flores: Selma, Emilio, Alberto, Marcos y Sonia; de Santiago Elena: Nico y Jasna y de José Antonio Daros: Jorge y Fernando. A todos ellos, y en especial al propio Ricardo Flores les debo muchos consejos y momentos. Ricardo ha sido un ejemplo para mi personal y científicamente durante todo este tiempo. Me siento muy orgulloso de que además me haya escrito una carta de referencia para mi futuro postdoctoral.

Debo agradecer también a todos mis compañeros de la primera promoción del Master en Biotecnología Celular y Molecular de Plantas: Paz, Bernardo, Ana Cristina, Gaetano, Javi, Carol y Eva. Pasamos un montón de tardes juntos, que he echado de menos en muchos momentos.

A la gente del Centro de Genómica del IVIA con los que empecé esta carrera científica: Paco Legaz, Manolo Talón, Chema Colmenero, Kiko Tadeo, Javier Brumós, Javier Agustí, Fernando Andrés, Miguel Ángel Naranjo y Ángel Boix. Es un placer mantener vuestra amistad durante tanto tiempo e incluso ahora, que la mayoría están lejos de Valencia.

También debo agradecer a Jaime Cebolla, Jaime Prohens y Alejandro Atarés la rapidez con la que se pudo solucionar el problema con respecto a los problemas administrativos previos a la lectura de esta tesis. Así mismo agradezco al personal de administración de la Universidad Politécnica de Valencia, y en especial al jefe de la unidad administrativa de doctorado Miguel Granell León, la rápida solución que dieron a los problemas que había generado mi matrícula.

Estoy seguro de que se me olvida un montón de gente a la que agradecer en esta tesis. Les pido disculpas a todos lo que olvido. No es intencionado, es solo mala memoria. 


Por. 

ABREVIATURAS..............................................................................................................

RESUMEN

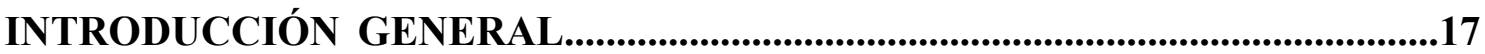

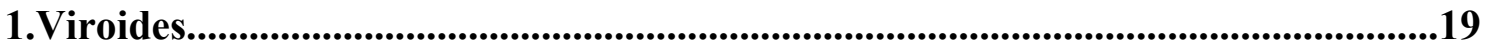

1.1 Características generales..................................................................................19

1.2. Localización subcelular y replicación de los viroides.....................................22

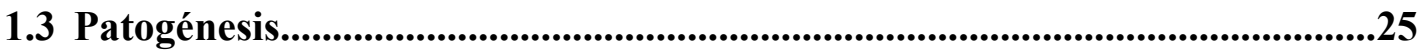

1.3.1. Patogénesis mediada por el RNA viroidal per se

1.3.2. Patogénesis mediada por silenciamiento de RNA

1.3.3. El viroide del enanismo del lúpulo (HSVd)

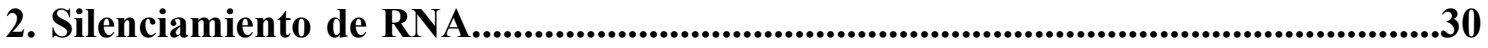

2.1 Características básicas del silenciamiento de RNA en plantas......................30

2.2 Componentes principales de la maquinaria de silenciamiento.....................32

2.2.1 Dicer-Like

2.2.2 Argonauta

2.2.3 RDRs

2.3. Las distintas rutas del silenciamiento de RNA en plantas. 35

2.3.1 Micro RNAs (miRNAs)

2.3.2 trans-acting siRNAs

2.3.3 siRNAs asociados a transcritos naturales antisentido (nat-siRNAs)

2.3.4 siRNAs heterocromáticos (hc-siRNAs)

2.4. El movimiento sistémico de la señal de silenciamiento de RNA...................44

3. Interrelacion entre patogénesis y silenciamiento de RNA.................................46

3.1. El silenciamiento de RNA y la patogénesis inducida por agentes infecciosos no viroidales

3.1.1 Acumulación de sRNAs derivados del patógeno

3.1.2 sRNAs endógenos con expresión alterada por patógenos

3.2 La relación entre silenciamiento de RNA y la patogénesis inducida por viroides

3.2.1 Los viroides inducen la acumulación de sRNAs derivados de su genoma

3.2.2 Características y biogénesis de los vd-sRNAs 
3.2.3 Efecto de los vd-sRNAs sobre las moléculas viroidales

3.2.4 Los vd-sRNAs y su relación con la patogénesis

JUSTIFICACIÓN Y OBJETIVOS

CAPÍTULOS.

Capítulo I: Analysis of symptoms developed in Nicotiana benthamiana plants expressing dimeric forms of Hop stunt viroid... . .65

Capítulo II: Viroid-induced symptoms in Nicotiana benthamiana plants are dependent on RDR6 activity

Capítulo III: High-throughput sequencing of Hop stunt viroid-derived small RNAs from cucumber leaves and phloem 105

Capítulo IV: High-throughput sequencing, characterization and detection of novel and conserved cucumber miRNAs. .135

Capítulo V: miRNA-mediated regulatory networks affected by Hop stunt viroid infection and prediction of endogenous targets for viroid-derived sRNAs. 


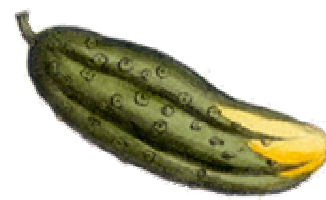

Abreviaturas 
ADFVd: Apple dimple fruit viroid. Viroide del fruto picado del manzano.

AGO: Argonaute protein. Proteina Argonauta.

AGVd: Australian grapevine viroid. Viroide australiano de la vid.

ASBVd : Avocado sunblotch viroid. Viroide del manchado solar del aguacate.

ASSVd: Apple scar skin viroid. Viroide de la piel cicatrizada de la manzana.

C: Central domain. Dominio central.

CAP (extremo): Cap. Caperuza o casquete del RNA mensajero.

CBLVd: Citrus bent leaf viroid. Viroide de la hoja curvada de los cítricos.

CbVd-1: Coleus blumei 1 viroid. Viroide 1 del coleus blumei.

CbVd-2: Coleus blumei 2 viroid. Viroide 2 del coleus blumei.

CCCVd: Coconut cadang cadang viroid. Viroide del cadang-cadang del cocotero.

CChMVd: Chrysanthemum chlorotic mottle viroid. Viroide del moteado clorótico del crisantemo

CCR: Central conserved region. Región central conservada.

cDNA: Complementary DNA. DNA complementario.

CEVd: Citrus exocortis viroid. Viroide de la exocortis de los cítricos.

CLSY: Chromatin remodeling. Remodelador de la cromatina.

CLVd : Columnea latent viroid. Viroide latente de columnea.

CMV: Cucumber mosaic virus. Virus del mosaico del pepino.

cRNA: Copy RNA. RNA copia.

CSVd: Chrysanthemum stunt viroid. Viroide del enanismo del crisantemo.

CtiVd: Coconut tinangaja viroid. Viroide del tinangaja del cocotero.

CVd-III: Citrus III viroid. Viroide III de los cítricos.

CVd-IV : Citrus IV viroid. Viroide IV de los cítricos.

DCL: Dicer-like RNase III. RNasa de tipo III dicer-like.

DNA: Deoxyribonucleic acid. Acido desoxiribonucleico. 
DRD: Defective in RNA-directed methylation. Defectivo en metilación mediada por RNA.

DRM: Domain rearranged methyltransferase protein. Metiltransferasa DRM.

dsRBD: Double-stranded RNA binding domain. Dominio de unión a RNA bicatenario. dsRNA: Double stranded RNA. RNA bicatenario.

DUF283: Domain of unknown function 283. Dominio de función desconocida 283.

ELVd: Eggplant latent viroid. Viroide latente de la berenjena.

ETI: Effector-triggered immunity. Inmunidad inducida por efectores.

GFP: Green fluorescence protein. Proteina verde fluorescente.

GTP: Guanosine 5'-triphosphate. Guanosina-5'-trifosfato.

GUS: Beta-glucuronidase. Beta glucuronidasa.

GYSVd-1: Grapevine yellow speckle 1 viroid. Viroide 1 del moteado amarillo de la vid.

GYSVd-2: Grapevine yellow speckle 2 viroid. Viroide 2 del moteado amarillo de la vid.

HC-pro: Viral helper component-protease. Proteasa del componente ayudante viral.

hc-siRNAs: Heterochromatic small interfering RNAs. Pequeños RNAs interferentes heterocromáticos.

His: Histidine. Histidina.

HLVd: Hop latent viroid. Viroide latente del lúpulo.

HST: HASTY.

HSVd : Hop stunt viroid. Viroide del enanismo del lúpulo.

IrVd-1: Iresine 1 viroid. Viroide 1 de iresine.

IsiRNAs: Long small interfering RNAs. Pequeños RNAs interferentes largos.

MIR : Primary micro RNA coding gene. Gen que codifica para un miRNA primario.

miRNA*: Micro RNA complementary strand. Hebra complementaria del miRNA.

miRNA: Micro RNA. micro RNA

MPVd: Mexican papita viroid. Viroide de la papita mejicana. 
mRNA: Messenger RNA. RNA mensajero.

NAT: Natural antisense transcripts. Transcritos naturales antisentido.

nat-siRNAs: Natural antisense small interfering RNAs. Pequeños RNAs interferentes naturales antisentido.

NRPD1b: Nuclear DNA-dependent RNA polymerase IV b subunit. Subunidad b de la RNA polimerasa nuclear dependiente de DNA IV.

nts: Nucleotides. Nucleótidos.

ORMV: Oilseed rape mosaic virus. Virus del mosaico de la colza.

P: Pathogenic domain. Dominio patogénico.

P-C (grupo): Plum-citrus phylogenetic group. Grupo filogenético ciruelo-cítricos.

PCVd: Pear blister canker viroid. Viroide de los chancros pustulosos del peral.

PIWI: P-element induced wimpy testis. Elemento P inductor de testículos "cobardicas".

PLMVd: Peach latent mosaic viroid. Viroide del mosaico latente del melocotonero.

pre-miRNA: Pre-micro RNA. pre micro RNA

pri-miRNA: Primary micro RNA. micro RNA primario

PSTVd: Potato spindle tuber viroid. Viroide del tuberculo fusiforme de la patata.

PTGS: Post-transcriptional gene silencing. Silenciamiento génico postranscripcional.

PTI: PAMP-triggered induced immunity. Inmunidad inducida por patrones de moléculas asociadas a patógenos.

PVY: Potato Y virus. Virus Y de la patata.

rDNA: Ribosomal DNA. DNA ribosomal.

RDR: $R N A$ dependent RNA polymerase. Polimerasa de RNA dependiente de RNA.

RISC: RNA-induced silencing complex. Complejo inductor del silenciamiento de RNA.

RNA pol IV: $R N A$ polymerase $I V$. RNA polimerasa IV.

RNA : Ribonucleic acid. Acido ribonucleico.

RNA-pol II: $R N A$ polymerase II. Polimerasa de RNA II. 
SGS: Supressor of gene silencing. Supresor del silenciamiento génico.

siRNA: Small interfering RNA. Pequeño RNA interferente

sRNA: Small RNA. Pequeño RNA

ssRNA: Single stranded RNA. RNA monocatenario.

TAS (loci): Trans-acting small interfering RNA gene loci. Loci de un gen que produce pequeños RNAs interferentes con actividad en trans.

ta-siRNA o tasiRNA: Trans acting small interfering $R N A$. Pequeño RNA interferente con actividad en trans.

TASVd: Tomato apical stunt viroid. Viroide del enanismo apical del tomate.

TCDVd: Tomato chlorotic dwarf viroid. Viroide del enanismo clorótico del tomate.

TCH: Terminal conserved hairpin. Horquilla terminal conservada.

TCR: Terminal conserved region. Región terminal conservada.

TEV: Tobacco etch virus. Virus del grabado del tabaco.

TGS: Transcriptional gene silencing. Silenciamiento génico transcripcional.

TL: Left terminal domain. Dominio terminal izquierdo.

TMV: Tobacco mosaic virus. Virus del mosaico del tabaco.

ToMV: Tomato mosaic virus. Virus del mosaico del tomate.

TPMVd: Tomato planta macho viroid. Viroide de la planta macho del tomate.

TR: Right terminal domain. Dominio terminal derecho.

TRV: Tobacco rattle virus. Virus del cascabeleo del tabaco.

TuMV: Turnip mosaic virus. Virus del mosaico del nabo.

U257A: Nucleotidic change $U$ by $A$ in position 257. Cambio nucleotídico en la posición 257, U por A.

UTR: Untranslated region. Región no traducible.

V: Variable domain. Dominio variable.

vdsRNAs: Viroid small RNAs. Pequeños RNAs viroidales.

vsRNAs: Viral small RNAs. Pequeños RNAs virales. 
XRN4: Exoribonuclease 4. Exoribonucleasa 4. 


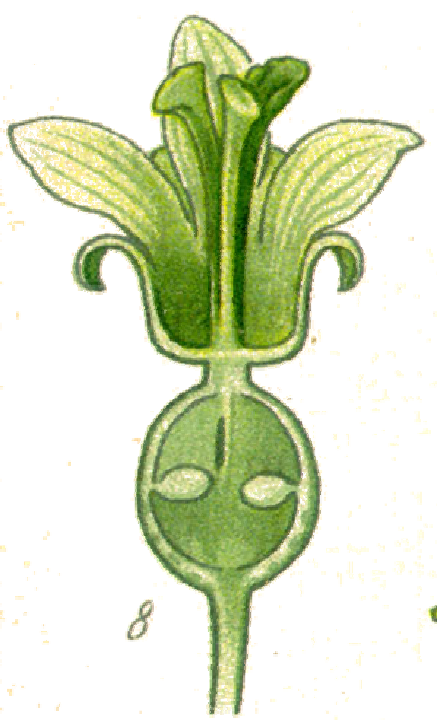

Resumen 
Los viroides son los patógenos de plantas conocidos con menor complejidad biológica. En los últimos años han sido descritos como agentes infecciosos de un gran numero de especies (tanto herbáceas como leñosas) de interés agronómico. Su estudio, aparte del interés agro-económico que puede reportar, resulta atractivo por el hecho de que representa el modelo más simple para estudiar las interacciones entre patógenos de RNA y sus huéspedes. Como estos organismos no poseen capacidad descrita para codificar proteínas, todas las fases de su ciclo vital, así como la respuesta patogénica inducida durante su infección, son estrictamente dependientes de su interacción con factores del huésped. La visión clásica del proceso de patogénesis viroidal asume que las alteraciones inducidas en la planta durante la infección son consecuencia de la competencia huésped-patógeno por factores celulares implicados en la transcripción, el movimiento célula a célula y/o el movimiento sistémico del viroide. Sin embargo, una serie de resultados obtenidos en estudios previos sugieren que posiblemente la respuesta de silenciamiento de RNA del huésped frente a estos patógenos sea la responsable del proceso de patogénesis asociado con la infección viroidal. En el presente trabajo se ha tratado de estudiar la relación entre dicho mecanismo de silenciamiento de RNA y la patogénesis viroidal (en concreto de HSVd).

El primer paso, reflejado en el Capítulo 1 de esta tesis, fue el caracterizar las alteraciones en el desarrollo inducidas por HSVd en plantas transgénicas de $N$. benthamiana. En regla general, el análisis de las alteraciones fenotípicas en plantas de $N$. benthamiana que expresaban formas diméricas de HSVd confirmó su similitud con los síntomas asociados a la infección del viroide en sus huéspedes naturales, justificando en consecuencia emplear el sistema HSVd/Nicotiana benthamiana como modelo para el estudio del proceso de patogénesis inducido por los viroides nucleares.

Ante la serie de resultados contradictorios que existían en la literatura sobre la implicación del silenciamiento de RNA en la patogénesis viroidal, consideramos que era necesario aportar nuevas evidencias que permitieran arrojar luz sobre esta relación de una manera directa, esto es, estudiando la interacción entre componentes fundamentales de la maquinaria de silenciamiento de RNA y los viroides. Para realizar este análisis (capítulo 2) estudiamos 2 variables que afectan al silenciamiento de RNA: una bioquímica, la actividad RDR6, y otra ambiental, la temperatura. Los resultados nos indican que en la interacción HSVd-N.benthamiana la expresión de síntomas es un proceso ligado al silenciamiento de RNA mediado por RDR6 e independiente de los niveles de acumulación del patógeno en la planta, aportando la primera evidencia 
experimental directa sobre la existencia de una estrecha relación entre la patogénesis viroidal y el silenciamiento de RNA específico de viroides, que había sido previamente sugerida por diversos autores.

Con la finalidad de profundizar en la biogénesis de los vd-sRNAs llevamos a cabo un experimento de secuenciación masiva de vd-sRNAs en dos tejidos diferentes de Cucumis sativus (huésped natural para HSVd), hoja y exudado floemático. Estos datos, expuestos en el capítulo 3, indican que los vd-sRNAs se originan por la acción jerarquizada de diversas DCLs sobre un dsRNA complementario generado a partir de un precursor lineal y no de la molécula madura. Además, los datos de la librería generada a partir de sRNAs derivados de exudado floemático indican una distribución diferencial de tamaño y secuencia en este tejido.

Pese a todos los reportes existentes acerca de cómo diversos patógenos afectan el balance de miRNAs en la planta, no existían estudios dedicados a analizar en profundidad como el proceso de infección viroidal altera los niveles este tipo de reguladores en el huésped. Teniendo en cuenta que, además, no habían sido caracterizados en esta especie, nuestro primer objetivo fue realizar un inventario de los sRNAs endógenos de pepino así como una caracterización de los miRNAs encontrados y sus potenciales precursores (capítulo 4). Con esta caracterización, disponíamos de un marco de referencia para poder analizar las alteraciones en este grupo de riboreguladores asociadas al proceso infeccioso inducido por HSVd (capítulo 5). Los resultados obtenidos nos permitieron identificar 4 tipos diferentes de alteraciones inducidas por el HSVd durante la infección: a) alteración del perfil general de sRNAs, siendo la familia de 21 nts la de mayor acumulación en planta infectada, b) represión y sobrexpresión de un grupo de miRNAs, c) expresión diferencial en planta infectada de un grupo de miRNAs específicos de pepino, y d) alteración en la eficiencia de procesamiento de los miRNAs de planta enferma en general. Finalmente, concluimos con el análisis bioinformático de la capacidad de los vd-sRNAs de regular la expresión de genes endógenos de la planta. En su gran mayoría los potenciales targets coinciden con genes relacionados con procesos de desarrollo, metabolismo de proteínas, respuesta a estrés, regulación de la trascripción, biogénesis celular, etc. Esto permite especular sobre la existencia de una relación directa en la regulación negativa de algunos de estos genes mediada por los vd-sRNAs y los síntomas comúnmente observados en una planta infectada. 
Els viroids són els patògens vegetals coneguts amb menor complexitat biològica. En els últims anys han sigut descrit com a agents infecciosos d'un gran numere d'espècies (tant herbàcies com llenyoses) amb interés agronòmic. El seu estudi a banda de l'interés agre-econòmic que pot reportar, resulta atractiu pel fet que representa el model més simple per a estudiar les interaccions entre patògens de RNA i els seus hostes. Com aquesto organismes no posseïxen capacitat descrita per a codificar proteïnes, totes les fases del seu cicle vital, així com la resposta patogènica induïda durant la seua infecció, són estrictament dependent de la seua interacció amb factors de l'hoste. La visió clàssica del procés de patogènesi viroidal assumix que les alteracions induïdes en la planta durant la infecció són conseqüència de la competència hostepatogen per factors cel·lulars implicats en la transcripció, el moviment cèl·lula a cèlllula i/o el moviment sistèmic del viroid. No obstant això una sèrie de resultats obtinguts en estudis previs suggerixen que possiblement la resposta de silenciament de RNA de l'hoste enfront d'estos patògens siga la responsable del procés de patogènesi associada amb la infecció viroidal. En el present treball s'ha tractat d'estudiar la relació entre el dit mecanisme de silenciament de RNA i la patogènesi viroidal (en concret del HSVd).

El primer pas, reflectit en el capítol 1 d'esta tesi, va ser el caracteritzar les alteracions en el desenvolupament induïdes per HSVd en plantes transgèniques de $\mathrm{N}$. benthamiana. En regla general, l'anàlisi de les alteracions fenotípiques en plantes de $N$. benthamiana que expressaven formes dimériques de HSVd va confirmar la seua similitud amb els símptomes associats a la infecció del viroid en els seus hostes naturals, justificant en conseqüència emprar el sistema HSVd/Nicotiana benthamiana com a model per a l'estudi del procés de patogènesi induïda pels viroids nuclears.

Davant de la sèrie de resultats contradictoris que existien en la literatura sobre la implicació del silenciament de RNA en la patogènesi viroidal, considerem que era necessari aportar noves evidències que permeteren fer llum sobre esta relació d'una manera directa, açò és, estudiant la interacció entre components fonamentals de la maquinària de silenciament de RNA i els viroids. Per a realitzar esta anàlisi (capítol 2) estudiem 2 variables que afecten el silenciament de RNA: una bioquímica, la RDR6 i una altra ambiental, la temperatura. Els resultats mostrats en este capítol indiquen que en la interacció HSVd-N.benthamiana l'expressió de símptomes és un procés estrictament lligat al silenciament de RNA mediat per RDR6 i totalment independent dels nivells d'acumulació del patogen en la planta, aportant la primera evidència experimental directa sobre l'existència d'una estreta relació entre la patogènesi viroidal i 
el silenciament de RNA específic de viroids, que havia sigut prèviament suggerida per diversos autors.

Amb la finalitat d'aprofundir en la biogènesi dels vd-sRNAs, dada que ens oferix un retrat més exacte sobre que components de la maquinària de silenciament i les formes precursores del viroid que podrien estar implicats en la producció de vd-sRNAs, duem a terme un experiment de seqüenciació massiva de vd-sRNAs en dos teixits diferents de Cucumis sativus (hoste natural per al HSVd), fulla i exsudat floematic. Estes dades, exposade en el capítol 3, indiquen que els vd-sRNAs s'originen per l'acció jerarquitzada de diverses DCLs sobre un dsRNA complementari generat a partir d'un precursor lineal i no de la molècula madura. A més, les dades de la llibreria generada a partir de sRNAs derivats d'exsudat floematic, indiquen una distribució diferencial de grandària i seqüència en este teixit.

A pesar de tots els reports existents sobre com diversos patògens afecten el balanç de miRNAs en la planta, no existien estudis en profunditat dedicats a analitzar en profunditat com el procés d'infecció viroidal altera els nivells este tipus de RNA reguladors en l'hoste. Tenint en compte que a més, no havien sigut caracteritzats en esta espècie, el nostre primer objectiu va ser realitzar un inventari dels sRNAs endògens de cogombre així com una caracterització dels miRNAs trobats i els seus potencials precursors (capítol 4). Amb aquesta caracterització, disposàvem d'un marc de referència per a poder analitzar les alteracions en este grup de ribo-reguladores associades al procés infecciós induït per HSVd (capítol 5). Els resultats obtinguts ens van permetre identificar 4 tipus diferents d'alteracions induïdes per HSVd durant la infecció: a) alteració del perfil general de sRNAs, sent la família de 21 nts la de major acumulació en planta infectada, b) repressió i sobreexpressió d'un grup de miRNAs, c) expressió diferencial en planta infectada d'un grup de miRNAs específics de cogombre, i d) alteració en l'eficiència de processament dels miRNAs de planta infectada en general. Finalment, concloem amb l'anàlisi bioinformàtica d'un dels aspectes fonamentals de la hipòtesi de patogènesi viroidal mediada per silenciament de RNA, l'estudi de la capacitat dels vd-sRNAs de regular l'expressió de gens endògens de la planta. En la seua gran majoria els potencials targets coincidixen amb gens relacionats amb processos de desenrotllament, metabolisme de proteïnes, resposta a estrés, regulació de la transcripció, biogènesi cel·lular, etc. Açò permet especular sobre l'existència d'una relació directa en la regulació negativa d'alguns d'estos gens mediada pels vd-sRNAs i els símptomes comunament observats en una planta infectada. 
Viroids are exclusively plant pathogens with the lowest biological complexity. In the last years they have been reported as infectious agents on a broad number of species (herbaceous and woody) of agricultural interest. Their study, apart from the agro-economic interest that it could report, is interesting by the fact that it is the simpliest model to study the interactions between RNA pathogens and their hosts. As viroids genome does not codify for proteins, all the steps of their life cycle are strictly dependents on the interaction with host factors. The classical point of view of the viroid pathogenic process asumes that the alterations induced in the plant are consequence of the competence host-pathogen for the cellular factors that have a role in the transcription, cell to cell movement or the systemic movement of the viroid. Nevertheless some new results suggest that the host RNA silencing activation against these pathogens is the responsible of the pathogenic process asociated with viroid infection. On this thesis we have studied the relationship between the RNA silencing mechanism and the viroid pathogenesis (concretely the induced by HSVd).

The first step (chapter 1) was the characterization of the developmental alterations induced by the HSVd on transgenic Nicotiana benthamiana plants, that were transformed with a construction that carried a dimerico form of this viroid. In a general view, the analysis of the phenotipic alterations on N.benthamiana-HSVd2x transgenic plants, confirmed their similarity with the symptoms asociated on natural hosts with viroid infection, what lead us to justify our system (N.benthamiana-HSVd2x transgenic plants) as a model to study the pathogenic process induced by nuclear viroids.

Facing a series of contradictory results in the literature about the involvement of RNA silencing on viroid pathogesis, we considered that it was necesary to carry a direct approach in order to study the interaction between main factors of the RNA silencing machinery and viroids.

To carry this analysis (chapter 2) we studied 2 variables that were previously reported to affect RNA silencing: a biochemical variable, RDR6, and an enviromental variable, temperature. The results shown on this chapter point to RNA silencing mediated by RDR6 as the main contributor to symptom expression on the interaction HSVd-N.benthamiana, that, moreover, is independent of the pathogen accumulation levels. This is the first direct experimental evidence about the existence of a close relationship between viroid pathogenesis and viroid specific RNA silencing, that was previously suggested by several authors. 
One of the questions that arrise from chapter 2 is which could be the RNA silencing RDR6 dependent pathway responsible for the pathogenic process of nuclear viroids. Several observations lead us to propose that the pathogenic process induced by viroids may be asociated with the trans-acting siRNAs (tasiRNAs) biogenesis pathway.

With the aim of getting deeper on vd-sRNAs biogénesis, which will offer a much exact portrait about which components of the silencing machinery and which viroid form could be implied in the production of vd-sRNAs, we carried a vd-sRNAs masive sequencing on two different Cucumis sativus (a HSVd natural host) tissues, leaf and phloem exudate. This data, shown on chapter 3, indicate that vd-sRNAs are originated as the result of the jerarquic action of different DCL proteins agains a dsRNA generated from a linear precursor and not from the mature form. Moreover, the phloem library vd-sRNA data showed that there is a differential distribution in terms of size and sequence on this tissue.

Although previous reports about how diverse pathogens change the miRNA levels in plants, there were not deep studies about the effect of viroid infection over this kind of RNA regulators in their hosts. Keeping in mind that, moreover, miRNAs hasn't been descrived in Cucumis sativus, our first step was the description of the endogenous sRNA repertoire and the characterization of the miRNAs and their precursors (chapter $4)$.

Once determined the characteristics of Cucumis sativus endogenous sRNAs, we had a reference to analyze their alterations asociated with the infectious process induced by HSVd (chapter 5). Our results lead us to identify 4 different kinds of alterations induced by HSVd infection: a) sRNA general profile alteration, being the $21 \mathrm{nts}$ size class the most accumulated on infected plant, b) repression and over-expression of some miRNAs, c) differential expression of specie-specific miRNAs on infected plants and d) alteration of the fidelity of procesing precission of miRNAs on infected plants.

Finally we conclude the thesis with a bioinformatic analysis of one of the main features of the viroid pathogenesis RNA silencing related hypothesis, the potentiallity of vd-sRNAs to regulate endogenous gene expression on plants. Potential targets are mainly related with developmental processes, protein metabolism, stress response, transcription regulation, cellular biogenesis etc. This allow us to speculate about the existence of a direct relationship of the negative regulation of some of these genes mediated by vd-sRNAs and the sympthoms observed on infected plants. 


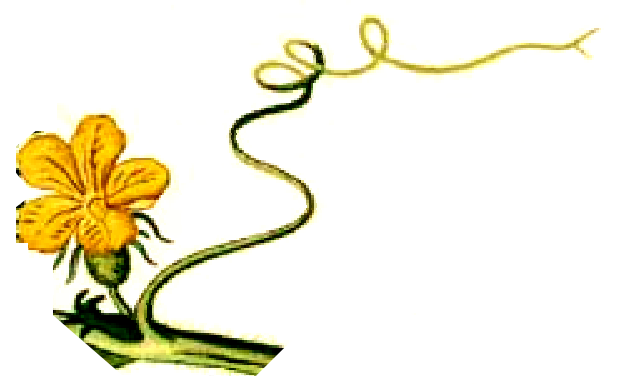

Introducción 


\section{Viroides}

\subsection{Características generales}

Los viroides son el peldaño inferior de la escala biológica. Poseen un genoma pequeño de RNA (246 a $401 \mathrm{nt}$ ) de simple cadena, circular, muy estructurado y sin capacidad de codificar proteínas. Estos RNAs son patógenos exclusivos de plantas y están obligados a interaccionar con la maquinaria metabólica de sus huéspedes para poder infectarlos (Diener, 2001; Flores et al., 2005; Ding, 2009). Su gama de hospedadores comprende un restringido número de especies tanto monocotiledóneas como dicotiledóneas de importancia agrícola, por lo que su impacto económico es potencialmente alto aunque difícilmente cuantificable.

El descubrimiento de los viroides estuvo asociado a la elucidación del agente causal de la enfermedad del tubérculo fusiforme de la patata (PSTVd) primero (Diener y Raymer, 1967; Diener, 1971a) y de la exocortis de los cítricos después (Semancik y Weathers, 1972). En ambos casos se determinó que dichos agentes causales no eran de naturaleza viral sino que presentaban las propiedades de un RNA de bajo peso molecular. Casi simultáneamente, se describió el viroide del enanismo del crisantemo (CSVd) (Diener y Lawson, 1973). Hasta el momento se han caracterizado biológica y molecularmente 30 especies de viroides y numerosas variantes de secuencia de las mismas (Flores et al. 2005, Tabla 1), que se han clasificado en dos familias: Pospiviroidae, cuya especie tipo es PSTVd (Gross et al., 1978), y Avsunviroidae, cuya especie tipo es el viroide del manchado solar del aguacate (ASBVd) (Symons, 1981).

Los viroides de la familia Pospiviroidae se caracterizan por poseer una región central conservada (central conserved region, CCR) (figura 1), así como por su replicación y localización nuclear. Los miembros de la familia Avsunviroidae, que no poseen estos motivos conservados, se replican y acumulan en el cloroplasto y sus RNAs de ambas polaridades se autocortan a través de estructuras ribozimáticas de cabeza de martillo (figura 2).

Los viroides nucleares (familia Pospiviroidae) adoptan una estructura en varilla con cinco dominios (Keese y Symons, 1985) que incluyen el central (C) conteniendo la CCR y flanqueado por los dominios patogénico $(\mathrm{P})$ y variable $(\mathrm{V})$, y los dos dominios terminales derecho (TR) e izquierdo (TL), este último conteniendo a su vez una región terminal conservada (terminal conserved region, TCR) o una horquilla terminal conservada (terminal conserved hairpin, TCH) (figura 1). 


\begin{tabular}{|c|c|c|c|c|}
\hline Abreviatura & Especie & Género & Familia & Tamaño (nts) \\
\hline PSTVd & Viroide del tubérculo fusiforme de la patata & Pospoviroid & Pospiviroidae & $356,359,360$ \\
\hline TCDVd & Viroide del enanismo clorótico del tomate & " & " & 360 \\
\hline TPMVd & Viroide de la planta macho del tomate & " & " & 360 \\
\hline MPVd & Viroide de la papita mejicana & " & " & $359-360$ \\
\hline CEVd & Viroide de la exocortis de los cítricos & $"$ & $"$ & $370-375$ \\
\hline CSVd & Viroide del enanismo del crisantemo & " & " & 354,356 \\
\hline TASVd & Viroide del enanismo apical del tomate & " & $"$ & 360,363 \\
\hline IrVd-1 & Viroide 1 de iresine & $"$ & $"$ & 370 \\
\hline CLVd & Viroide latente de columnea & " & " & $370,372,373$ \\
\hline HSVd & Viroide del enanismo del lúpulo & Hostuviroid & " & 297-303 \\
\hline CCCVd & Viroide del cadang-cadang del cocotero & Cocadviroid & $"$ & 246,247 \\
\hline CTiVd & Viroide del tinangaja del cocotero & " & " & 254 \\
\hline HLVd & Viroide latente del lúpulo & " & $"$ & 256 \\
\hline CVd-IV & Viroide IV de los cítricos & " & $"$ & 284 \\
\hline ASSVd & Viroide de la piel cicatrizada de la manzana & Apscaviroid & " & 329,33 \\
\hline CVd-III & Viroide III de los cítricos & " & " & 294,297 \\
\hline ADFVd & Viroide del fruto picado del manzano & " & " & 306 \\
\hline GYSVd-1 & Viroide 1 del moteado amarillo de la vid & " & " & 366,368 \\
\hline GYSVd-2 & Viroide 2 del moteado amarillo de la vid & " & $"$ & 363 \\
\hline CBLVd & Viroide de la hoja curvada de los cítricos & " & " & 318 \\
\hline PCVd & Viroide de los chancros pustulosos del peral & " & $"$ & 315,316 \\
\hline AGVd & Viroide australiano de la vid & $"$ & " & 369 \\
\hline CbVd-1 & Viroide 1 del coleus blumei & Coleviroid & " & 248,251 \\
\hline CbVd-2 & Viroide 2 del coleus blumei & " & " & 301 \\
\hline CbVd-3 & Viroide 3 del coleus blumei & $"$ & " & $361,362,364$ \\
\hline ASBVd & Viroide del manchado solar del aguacate & Avsunviroid & Avsunviroidae & $246-250$ \\
\hline PLMVd & Viroide del mosaico latente del melocotonero & Pelamoviroid & " & $335-338$ \\
\hline CChMVd & Viroide del moteado clorótico del crisantemo & " & " & 399 \\
\hline ELVd & Viroide latente de la berenjena & Elaviroid & " & $333-335$ \\
\hline
\end{tabular}

Tabla1. Clasificación de los viroides caracterizados molecularmente (adaptado de Flores et al., 2005). Los viroides se agrupan en dos familias, Pospiviroidae y Avsunviroidae, que contienen cinco y tres géneros respectivamente. Las especies tipo de cada género están señaladas en negrita. Se señalan en la tabla la abreviatura del nombre del viroide en inglés, su traducción al castellano, y el tamaño en nucleótidos de las especies descritas. 
El tipo de CCR, junto con la presencia o ausencia de los motivos TCR y TCH, son criterios de clasificación de los miembros de esta familia (Flores et al., 2005). Aunque los primeros análisis asignaron una función a cada dominio, la situación real no es tan simple. Por ejemplo, la expresión de síntomas asociada al dominio P parece estar controlada por determinantes discretos situados en los dominios TL, P, V y TR (Sano et al., 1992).

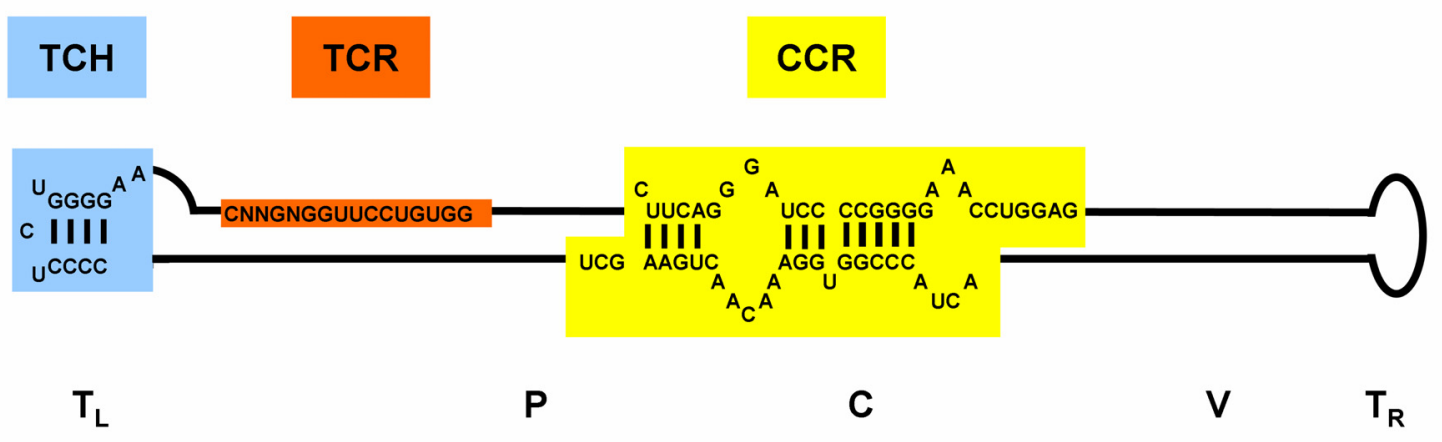

Figura 1. Representación esquemática de la estructura secundaria de tipo varilla propuesta para los viroides del género Pospiviroid de la familia Pospiviroidae. En la parte inferior se indica la localización aproximada de los dominios centra $(\mathrm{C})$, patogénico $(\mathrm{P})$, variable $(\mathrm{V})$, terminal izquierdo (TL) y terminar derecho (TR). Los nucleótidos que forman las regiones conservadas TCH, TCR y CCR se representan con nucleótidos señalados en negro sobre fondo azul, rojo y amarillo respectivamente.

Otra característica interesante de los viroides es su compleja estructura secundaria, consecuencia de la alta autocomplementariedad de sus secuencias. Todas las secuencias viroidales tienen un elevado contenido de G+C (mayor del 50\%) a excepción de ASBVd donde solamente es del 38\%. El uso de programas informáticos para realizar cálculos termodinámicos ha facilitado la predicción de la estructura secundaria de mínima energía que pueden adoptar estos RNAs. En general, los modelos estructurales predichos contienen tramos apareados intermolecularmente alternados con pequeños bucles desapareados, lo que otorga a los RNAs viroidales una estructura que se denomina en forma de varilla, cuasi-varilla o ramificada (esta última exclusiva de algunos miembros de la familia Avsunviroidae).

Si bien la predicción termodinámica no tiene por qué reflejar la situación in vivo, existen evidencias (como por ejemplo la comprobación de la estructura de PSTVd in vitro) que refuerzan la validez de estos modelos estructurales (Sogo et al., 1973; Sanger et al., 1976). Es interesante señalar que esta compleja estructura secundaria debe ser 
extremadamente importante in vivo, ya que tanto la introducción en PSTVd de deleciones que alteran su estructura secundaria (Wassenegger et al., 1994) como la aparición de repeticiones naturales en otros miembros de la familia Pospiviroidae (Randles et al., 1982; Semancik et al., 1994; Fadda et al., 2003), conducen a la aparición de variantes de secuencia que preservan su estructura de tipo varilla.

Por otra parte el análisis de variantes naturales de secuencia de PLMVd (Ambros et al., 1998, 1999; Pelchat et al., 2000; Malfitano et al., 2003; Rodio et al., 2006; Mandic et al., 2008; Hassan et al., 2009) y del viroide del moteado clorótico del crisantemo (CChMVd) (Navarro y Flores, 1997; de la Peña et al., 1999; de la Peña y Flores, 2002) han permitido observar diversas covariaciones y mutaciones compensatorias acordes con la adopción de una estructura ramificada, predicha para distintos miembros de la familia Avsunviroidae.

Los viroides no derivan de los virus actuales ni de degeneraciones de ellos ya que no tienen similitud de secuencia con estos y sus características biológicas y moleculares son profundamente diferentes. Se ha propuesto que deriven de plásmidos, intrones o elementos transponibles (Diener, 1981; Diener, 1989); sin embargo, la presencia de ribozimas de cabeza de martillo en algunos de ellos ha conducido a considerarlos como fósiles moleculares derivados de los primeros replicones que aparecieron en la Tierra, teóricamente compuestos de RNA, la única biomolécula conocida capaz de almacenar información genética y expresar actividad catalítica (Diener, 1989).

\subsection{Localización subcelular y replicación de los viroides:}

Las primeras aproximaciones al estudio de la localización subcelular de los viroides, se realizaron mediante técnicas de centrifugación diferencial. Estos experimentos sugirieron que la acumulación de PSTVd y otros viroides similares era nuclear (Diener, 1971b; Semancik et al., 1976) y que la de ASBVd era cloroplástica (Mohamed y Thomas, 1980). Posteriormente, el uso de técnicas de hibridación in situ con sondas fluorescentes y microscopía confocal confirmó la localización nuclear para PSTVd, CCCVd y CEVd (Harders et al., 1989; Bonfiglioli et al., 1996) y demostró que PSTVd y CCCVd se localizaban específicamente en el nucleolo. Aproximaciones de este tipo con miembros de la familia Avsunviroidae permitieron determinar que ASBVd y PLMVd acumulaban especificamente en el cloroplasto (Lima et al., 1994; Bussiere et al., 1999). 

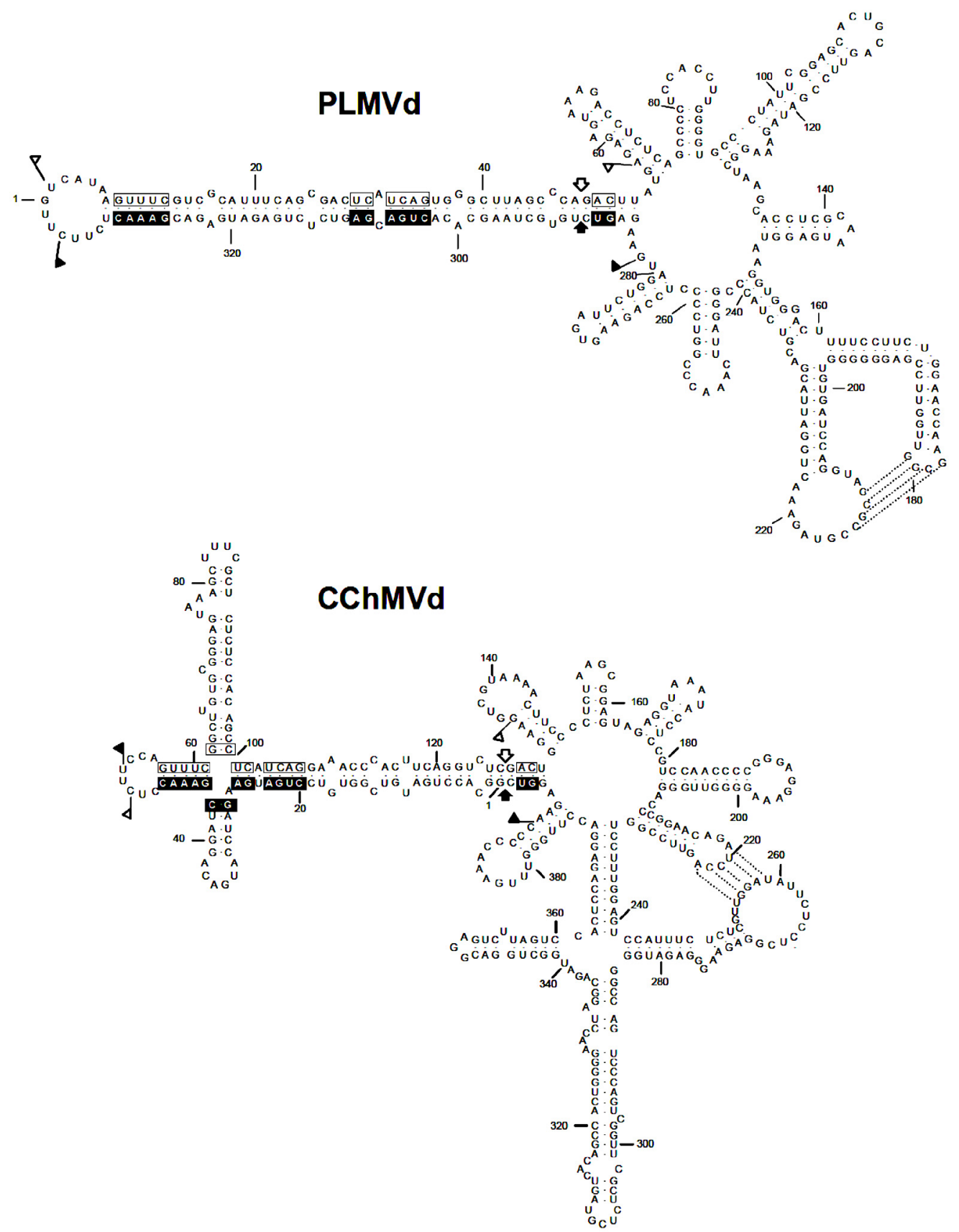

Figura 2. Representación de la estructura secundaria de tipo cuasi-varilla y ramificada para PLMVd y CChMVd, de la familia Avsunviroidae. Los nucleótidos estricta o altamente conservados se representan en recuadros con fondo negro y blanco para las polaridades positiva y negativa respectivamente. La interacción terciaria del tipo kissing-loops se representa con líneas discontinuas.

Diversos estudios han puesto de manifiesto que en la replicación de los viroides no existe ninguna fase mediada por DNAs (Branch y Dickson, 1980; Zaitlin et al., 1980). Sin embargo, se han descrito intermediarios de RNA tanto para viroides nucleares (Grill y Semancik, 1978) como cloroplásticos (Daros et al., 1994; Bussiere et al., 1999; Delgado et al., 2005). Estas observaciones, sumadas a la naturaleza circular de su genoma, han llevado a postular que la replicación de los viroides ocurre mediante 
un mecanismo de círculo rodante, con intermediarios de RNA. Este modelo contempla la existencia de dos variantes, asimétrica y simétrica, para la replicación de los viroides de ambas familias, respectivamente (Branch y Robertson, 1984; Ishikawa et al., 1984; Hutchins et al., 1985). Una descripción más detallada acerca de la evolución del modelo de replicación de los viroides puede encontrarse en las excelentes revisiones realizadas por Flores et al (2005) y Tsagris et al., (2008).

Una visión simplificada de este proceso (figura 3) nos muestra que en la variante asimétrica (familia Pospiviroidae) el RNA monomérico circular más abundante (arbitrariamente denominado de polaridad positiva) actúa como molde para la síntesis (mediada por RNAPol-II) de oligómeros de polaridad complementaria, que a su vez sirven como molde para una segunda transcripción RNA-RNA.

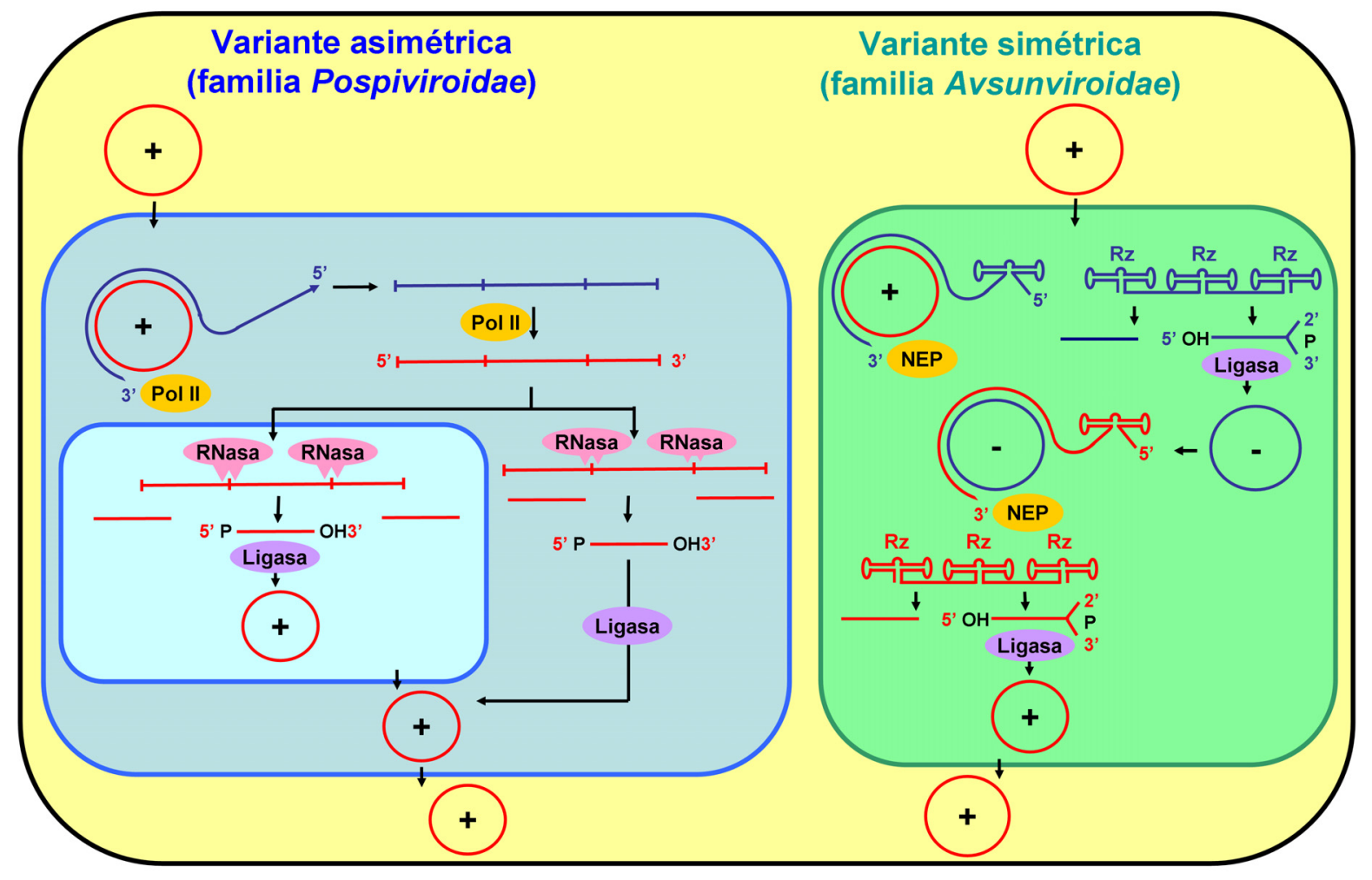

Figura 3. Mecanismo de círculo rodante con intermediarios de RNA propuesto para la replicación de los viroides (adaptado de Flores et al., 2005). En la parte izquierda se representa la variante asimétrica con un único círculo rodante seguida por los miembros de la familia Pospiviroidae en el núcleo. En la parte derecha se representa la variante simétrica con dos círculos rodantes seguida por los miembros de la familia Avsunviroidae en el cloroplasto.

Los multímeros de polaridad positiva resultantes de esta segunda transcripción son cortados en fragmentos de longitud unitaria y posteriormente circularizados por factores del huésped que continúan aún sin identificar. Los miembros de la familia Avsunviroidae siguen la variante simétrica, donde los multímeros de polaridad (-) 
resultantes de la trascripción del RNA circular monomérico de polaridad $(+)$ son procesados a formas circulares monoméricas que sirven de molde para la segunda parte del ciclo de replicación, simétrica a la primera. Una diferencia sustancial en la familia Avsunviroidae es que el corte necesario para generar las formas de longitud unitaria ocurre autocatalíticamente por la acción de las ribozimas de cabeza de martillo que pueden formar los RNAs de ambas polaridades.

\subsection{Patogénesis}

Los viroides infectan a una gran variedad de cultivos de importancia económica: patata, tomate, pepino, lúpulo, cocotero, viñedo, melocotonero, manzano, peral, ciruelo, cítricos, aguacate, crisantemo y coleo. Algunos viroides, como HSVd, poseen una amplia gama de huéspedes naturales mientras que otros, como los pertenecientes a la familia Avsunviroidae, suelen estar restringidos a un único huésped. La transmisión de los viroides en la naturaleza se produce principalmente por vía mecánica $\mathrm{y}$, en menor medida, a través de semilla o polen. Un caso excepcional es el de TPMVd, que es transmitido por pulgones bajo unas condiciones ecológicas muy específicas. Cabe destacar que la reproducción vegetativa de algunas especies agrícolas ha ayudado a que estas contengan una compleja mezcla de distintos viroides.

Los efectos de los viroides sobre sus huéspedes son diversos. Pueden causar su muerte (como es el caso de CCCVd sobre su huesped natural, cocotero) o afectar a un nivel menos dramático a hojas, tallos, corteza, flores, frutos, semillas u órganos de reserva o a nivel macroscópico produciendo retrasos en la aparición de hojas, flores y frutos. También afectan al patrón de crecimiento y por tanto al desarrollo vegetativo. Fenotípicamente todas estas afecciones son generalmente indistinguibles de los síntomas de algunas infecciones virales. En general, los síntomas inducidos por viroides son más evidentes en plantas sometidas a altas temperaturas y altas intensidades lumínicas. Por lo tanto, sus efectos son mayores en huéspedes restringidos a zonas tropicales o subtropicales.

Una de las cuestiones más intrigantes de la biología de los viroides es la relacionada con el proceso de patogénesis. Es realmente notorio que un RNA "desnudo" y sin capacidad de codificar proteínas pueda sobrevivir a la maquinaria de defensa de la célula huésped y desencadenar un proceso patogénico. En este sentido, y si bien en los últimos años se han realizado multiples esfuerzos para descifrar las bases moleculares 
del proceso infeccioso, los mecanismos por los cuales los viroides inducen la aparición de síntomas en la plantas huésped están aún lejos de ser elucidados.

Durante mucho tiempo se ha aceptado que la competencia por los factores celulares implicados en la transcripción, el movimiento célula a célula y/o el movimiento sistémico serían suficientes para desencadenar el proceso patogénico en la planta. De ser esto cierto, cabría esperar una relación directa entre el título del viroide y la intensidad de síntomas observados en el huésped. Sin embargo, esta situación no constituye la regla general observada en los procesos de patogénesis inducidos por viroides, lo que arroja serias dudas acerca de la validez o generalidad de este modelo (Tabler y Tsagris, 2004; Flores et al., 2005; Owens y Hammond, 2009). El paisaje que se dibuja por tanto en la patogénesis inducida por viroides es mucho más complejo, pudiendo abarcar procesos tales como la desregulación (a nivel transcripcional) de genes endógenos de la planta y/o la inducción de modificaciones traduccionales de los productos génicos. Este proceso podría estar mediado por la interacción directa del RNA-viroidal con factores (RNAs o proteínas) del huésped, o alternativamente por la relación/interferencia del ciclo replicativo del viroide con la maquinaria de silenciamiento de RNA de la planta (Wang et al., 2004; Ding, 2009; Owens y Hammond, 2009).

\subsubsection{Patogénesis mediada por el RNA viroidal per se}

La idea de que la interacción directa del viroide con factores del huésped regula la inducción de síntomas está basada en trabajos que demuestran que existen variaciones nucleotídicas en la secuencia del viroide asociadas con alteraciones en la intensidad de la repuesta patogénica. Por ejemplo, se ha observado que PSTVd y CEVd tienen una virulencia dependiente de cambios nucleotídicos en el dominio P (Schnolzer et al., 1985; Visvader y Symons, 1985; 1986). Además del dominio P, los dominios TL y C también están involucrados en la producción de síntomas (Sano et al., 1992; Qi y Ding, 2003). Por otra parte, incluso un solo cambio nucleotídico puede determinar el nivel de los síntomas producidos. Este es el caso del ASBVd, donde una inserción entre los nucleótidos 115 y 118 es responsable de la variación en la sintomatología (Schnell et al., 2001). PSTVd y HSVd también ven afectada su patogenicidad por cambios nucleótidicos simples en su secuencia (Qi y Ding, 2003; Serra et al., 2008). 


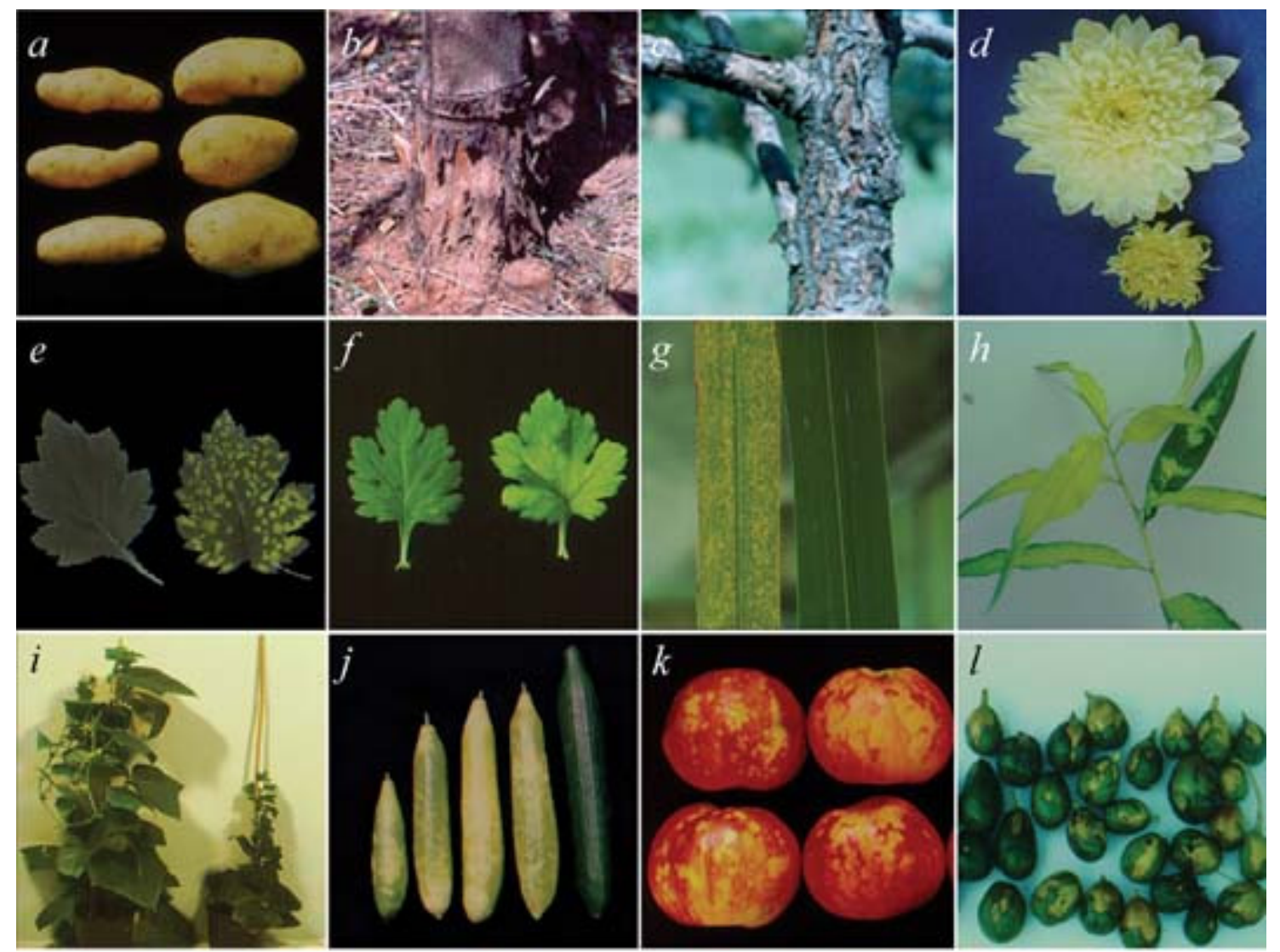

Figura 4. Ejemplos de sintomatología viroidal sobre distintos huéspedes. a) Sintomatología de PSTVd sobre tubérculos de patata (izquierda) comparados con controles sanos (derecha). b) Sintomatología ocasionada por CEVd sobre un patrón de naranjo trifoliata. c) Síntomas de PBCVd sobre peral A20. d) y e) Flores y hojas de una planta de crisantemo infectada con CSVd junto a sus controles sanos (flor superior y hoja izquierda). f) Efectos del CChMVd sobre hoja de crisantemo (derecha) junto a su control sano (izquierda). g) Efectos de CCCVd sobre hojas de coco (izquierda) comparadas con un control sano (derecha). h) Cálico (clorosis extrema) inducida por PLMVd en melocotonero. i) y j) Acortamiento de entrenudos y sintomatología en fruto, causadas por HSVd sobre plantas de pepino junto a control sano (planta izquierda y fruto derecho). k)Efecto de ASSVd sobre frutos de manzano. 1) Sintomatología de ASBVd sobre aguacates (Adaptado de Flores et al. 2005).

En el caso de PSTVd, el cambio nucleotídico U257A es una mutación espontánea en plantas transgénicas para el cDNA de este viroide en tabaco (Zhu et al., 2002). La mutación no afecta a la estructura secundaria o terciaria, ni al nivel de replicación ni a su distribución tisular. Sin embargo, los síntomas estaban relacionados con un menor crecimiento celular, correlacionado positivamente con la inhibición de la expresión del gen LeExp2, una expansina relacionada con el crecimiento en órganos jóvenes (Qi y Ding, 2003; Zhong et al., 2006).

Por lo que respecta a los miembros de la familia Avsunviroidae, cabe destacar que el proceso patogénico inducido por PLMVd está asociado a la inserción extra de un motivo en forma de horquilla de 12-13 nts en el dominio TL (Malfitano et al., 2003). 
Los síntomas típicos de este viroide son una clorosis extrema, con regiones totalmente albinas. Se ha demostrado que en estas regiones los cloroplastos están afectados en su desarrollo (Rodio et al., 2006) y en el procesamiento de precursores de los RNAs ribosomales del cloroplasto. Estos resultados fueron considerados por los autores como indicadores de una afección directa a la maquinaria de traducción cloroplástica mediada por el RNA viroidal (Rodio et al., 2007).

\subsubsection{Patogénesis mediada por silenciamiento de RNA}

El descubrimiento de que la replicación de PSTVd en tomate inducía la acumulación de pequeños RNAs derivados del viroide (Papaefthimiou et al., 2001) puso de manifiesto la posibilidad de que existiese una estrecha relación entre el proceso de infección viroidal y el silenciamiento de RNA. Estudios posteriores demostraron que este tipo de RNAs reguladores estaban asociados también a procesos patogénicos inducidos por miembros de la familia Avsunviroidae (Martinez de Alba et al., 2002) y a interacciones entre viroides con diferentes huéspedes. Estas observaciones indicaban que los viroides actuaban durante el proceso infeccioso como inductores del mecanismo de silenciamiento de RNA. En este contexto se postuló que los sRNAs derivados del viroide podrían mimetizarse con microRNAS endógenos y de esa manera afectar la expresión de distintos genes de la planta, ocasionado alteraciones fenotípicas expresadas como síntomas (Wang et al, 2004). En el apartado 3 de la introducción de esta tesis se ofrece un análisis más profundo de la interacción entre silenciamiento de RNA y patogénesis inducida por viroides.

\subsubsection{El viroide del enanismo del lúpulo (HSVd)}

El viroide del enanismo del lúpulo es el único miembro del género Hostuviroid perteneciente a la familia Pospiviroidae. El tamaño de su genoma varía de los 297 a los 303 nts. Es el viroide que tiene un mayor número de huéspedes naturales debido a su amplio número de variantes. Fue identificado por primera vez en Japón en los años 70 como agente causal de un severo enanismo en plantas de lúpulo (Sasaki y Shikata, 1977). Posteriormente ha sido descrito en multitud de huéspedes como pepino, vid, cítricos, melocotonero, peral, ciruelo (Shikata, 1990), albaricoquero (Astruc et al., 1996) y almendro (Cañizares et al., 1999). La infección causada por HSVd parece permanecer latente en algunos de sus huéspedes como vid y albaricoquero (Shikata, 1990; Astruc et al., 1996; Polivka et al., 1996) mientras que en otros causa importantes síntomas que 
ocasionan daños económicos en los cultivos que infecta como es el caso del enanismo en lúpulo (Shikata, 1990), la enfermedad del moteado del fruto de ciruelo y melocotonero (Sano et al., 1989) y la cachexia en cítricos (Diener et al., 1988). En campo, su transmisión ocurre principalmente por daño mecánico e injertos (Sano, 2003).

Los primeros análisis filogenéticos (Hsu et al., 1995) y de homología de secuencia (Shikata, 1990) indicaron que los aislados de HSVd podían separarse en tres grupos: tipo ciruelo (plum-type), tipo lúpulo (hop-type) y tipo cítrico (citrus-type). El hecho de que estos grupos fueron obtenidos con secuencias de aislados derivados de diferentes huéspedes llevó a la idea de que esta discriminación por grupos podría representar una especificidad de determinantes de secuencia o fuera requerida para su replicación específica de huésped. Posteriormente, análisis filogenéticos más detallados de las secuencias disponibles junto con otras nuevas procedentes de aislados de Prunus (Kofalvi et al., 1997) llevaron a una redefinición del agrupamiento de variantes de HSVd. Pese a que existía un sesgo con respecto a la presencia de ciertas secuencias y/o estructuras para algunos huéspedes, no se encontraron determinantes específicos de huésped. Además, este análisis reveló que posiblemente un cierto número de aislados podría haber derivado de eventos de recombinación y que, de hecho, el grupo tipo lúpulo podría ser el resultado de recombinaciones entre los grupos tipo ciruelo y cítrico (grupo P-C) (Kofalvi et al., 1997). La mayoría de las variantes de secuencias en albaricoquero se agrupan en el grupo tipo ciruelo o en uno de los grupos recombinantes menores (Amari et al., 2001). La observación de que un gran número de nuevas variantes de secuencia se agrupen en el grupo recombinante $\mathrm{P}-\mathrm{C}$ indica que estas variantes de secuencia son más frecuentes de lo que se pensaba. Las dos variantes de secuencia en almendro pertenecerían también al grupo tipo ciruelo. No obstante, ninguna variante de secuencia de albaricoquero o almendro pertenecen al tipo cítrico (Cañizares et al., 1999).

El análisis de la distribución geográfica de las secuencias de albaricoquero revelaron que la mayoría de las variantes marroquíes tienen relación filogenética con las variantes españolas, mientras que las variantes griegas de albaricoquero son más cercanas a las variantes alemanas encontradas en vid (Pallás et al., 2003). Lo que sugiere dos orígenes geográficos distintos para estos dos grupos de aislados procedentes de albaricoquero. Finalmente, la mayoría de las variantes de secuencia encontrados en Chipre se agrupan dentro del grupo recombinante P-C, lo que sugeriría que otras variantes de HSVd derivaron de un evento de recombinación intra-específica. 


\section{Silenciamiento de RNA}

El término silenciamiento de RNA engloba una serie de eventos por los cuales la expresión de uno o más genes se inhibe o suprime por el efecto de una molécula de RNA antisentido. El descubrimiento de que un RNA podía actuar como elemento regulador de los genomas eucariotas ha supuesto la última revolución en el campo de la biología molecular. La importancia de este mecanismo quedó plasmada en el premio Nobel en medicina o fisiología del año 2006 otorgado a Andrew Fire y Craig C. Mello, por el descubrimiento de este proceso en el organismo modelo Caenoharbditis elegans (Fire et al., 1998).

Este descubrimiento refuerza la hipótesis que propone que el RNA fue la base de la vida en la Tierra, cumpliendo el doble papel de almacenador pasivo de información y de catalizador activo de proceso bioquímicos. Con el aumento de la cantidad y complejidad de información genética, el RNA fue sustituido por el DNA (más estable) como molécula almacenadora mientras que las proteínas asumieron la labor enzimática (Bagasra y Prilliman, 2004; Vaucheret, 2006). Así, el RNA parecía aparentemente relegado a mero intermediario como traductor de la información almacenada en el DNA. Sin embargo, los últimos descubrimientos sobre silenciamiento de RNA han puesto de manifiesto que es un actor principal en procesos fundamentales como la preservación de la integridad del genoma, la defensa antiviral y la regulación del desarrollo (Vaucheret, 2006; Voinnet, 2008; Ruiz-Ferrer y Voinnet, 2009).

\subsection{Características básicas del silenciamiento de RNA en plantas}

En plantas, el silenciamiento de RNA engloba una serie de procesos que actúan a nivel transcripcional (transcriptional gene silencing, TGS) o postranscripcional (posttranscriptional gene silencing, PTGS). Ambos procesos tienen en común el reconocimiento específico de secuencias de DNA o RNA por pequeñas moléculas de RNA (small RNAs, sRNAs). Este mecanismo regulador está conservado en los cuatro reinos eucariotas y sus funciones son diversas: mantenimiento de la estabilidad del genoma (Vaucheret, 2006; Liu et al., 2010), regulación de procesos del desarrollo (Chen, 2009) y defensa frente a ácidos nucleicos invasores (Ruiz-Ferrer y Voinnet, 2009).

El silenciamiento se induce por la presencia de RNAs bicatenarios (dsRNA) de diverso origen o RNAs monocatenarios (ssRNAs) con una alta estructura secundaria (hairpins) que son procesados en moléculas de RNAs bicatenarias de entre 18 y $25 \mathrm{nts}$ (sRNAS) por RNasas de tipo III denominadas en plantas Dicer-Like (DCLs). Los 
sRNAs generados por la acción de DCL poseen dos nucleótidos protuberantes en los extremos 3' en ambas cadenas. Una RNA helicasa separa ambas cadenas de sRNAs y una de ellas es reclutada en un complejo inductor del silenciamiento (RNA-induced silencing complex, RISC), que contiene una proteína Argonauta (AGO) con actividad RNasa H, además de otros componentes. Una vez ensamblado, RISC es guiado por el sRNA hasta un RNA mensajero (mRNA) de secuencia complementaria (diana) al que este complejo se une induciendo la inhibición de su traducción o su degradación. En el TGS, este complejo efector es guiado hasta un DNA de secuencia complementaria al cual se une, induce su metilación y bloquea su transcripción, participando en la formación de la heterocromatina.

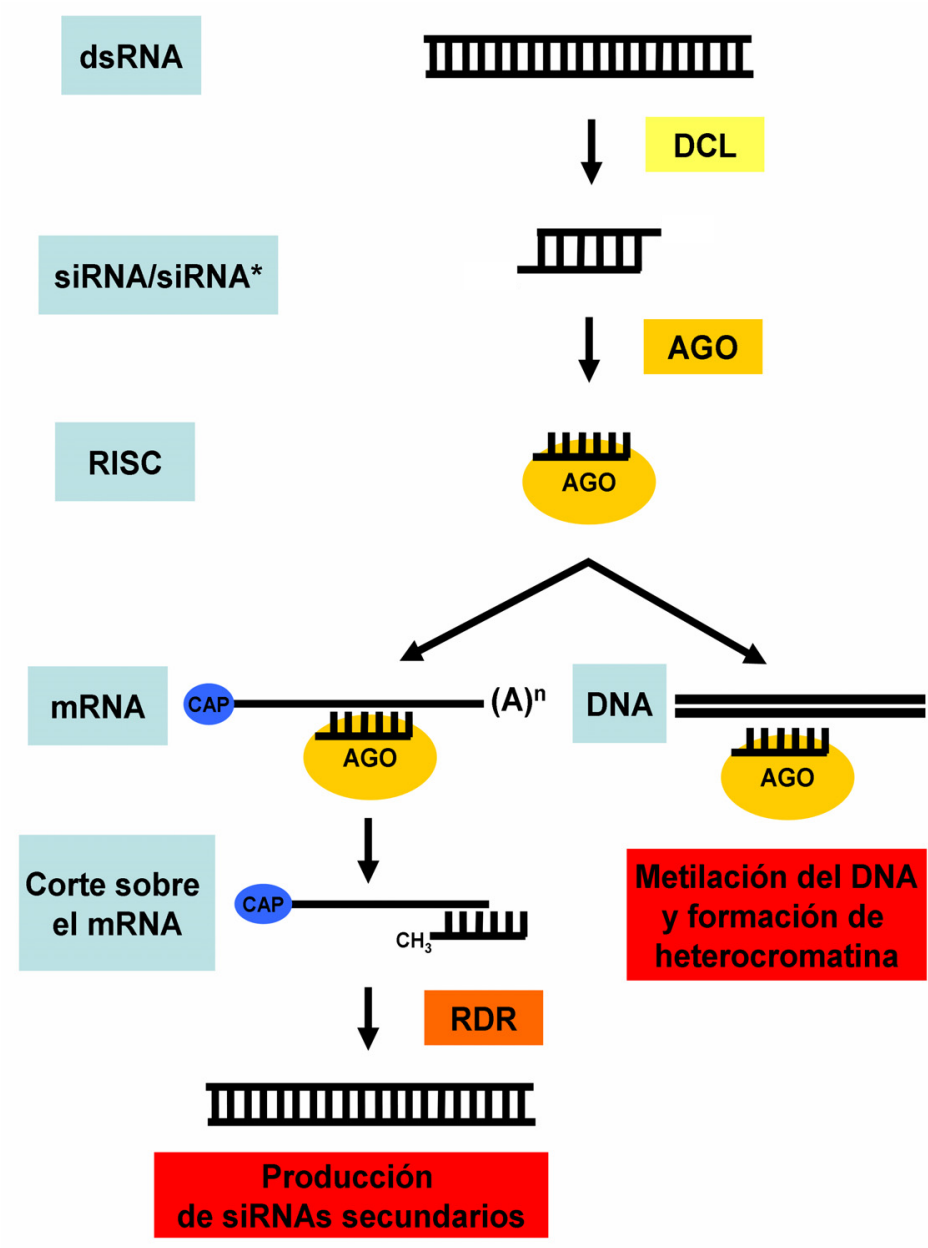

Figura 5. Esquema básico del proceso de silenciamiento de RNA. La maquinaria de silenciamiento de RNA se inicia con un dsRNA que es digerido por DCL en moléculas de sRNAs. Estos sRNAs son cargados e $n$ c o m p l e jos denominados RISC cuyo componente principal es una proteina AGO. Estos complejos tienen dos posibles destinos: Cortar un mRNA de secuencia homóloga al siRNA, inhibiendo así su traducción; o bien actuar sobre el DNA metilando la citosina o $1 \mathrm{as}$ histonas y form a n d o 1 a heterocromatina.

La respuesta de silenciamiento puede amplificarse mediante la síntesis de nuevos dsRNAs por la acción de una RNA polimerasa celular dependiente de RNA (RNA-dependent RNA polymerase, RDR) que utiliza como molde los ssRNAs generados tras el corte por el complejo RISC o sobre otros ssRNAs aberrantes. Estos dsRNAs son entonces procesados por DCL para generar los denominados sRNAs secundarios. 


\subsection{Componentes principales de la maquinaria de silenciamiento}

\subsubsection{Dicer-Like}

Las enzimas Dicer-Like descritas hasta el momento en plantas, son endoribonucleasas de tipo III que procesan de manera jerárquica dsRNA y pri-miRNA en sRNAs bicatenarios de entre 18 y 25 nts, con dos nucleótidos libres en 3'. El término Dicer fue acuñado por Emily Bernstein, una estudiante del grupo de Greg Hannon que descubrió la actividad "cortadora" (to dice en inglés) de esta enzima sobre dsRNAs (Bernstein et al., 2001). Como regla general (plantas, insectos, protozoos y hongos como Neurospora crassa o Magnaporthe oryzae) las DCLs conforman pequeñas familias génicas compuestas por 2, 4 o 5 miembros. Por contrapartida solamente se ha descrito una proteína Dicer en vertebrados, nematodos, Schizosaccharomyces pombe y Chlamydomonas reinhardtii (Liu et al., 2009).

Las proteínas DCLs contienen 6 tipos de dominios: DEAD box, helicasa-C, DUF283, PAZ, RNasa III y dsRBD (Margis et al., 2006) (Figura 6). Los dominios PAZ, RNasa III y dsRBD actúan en la unión y la digestión del dsRNA. El dominio PAZ se encuentra directamente conectado al dominio RNasa IIIa por una hélice alfa y puede unirse específicamente al final de un dsRNA con dos bases libres en 3' (Macrae et al., 2006) o a un ssRNA (Kini y Walton, 2007). Se ha propuesto (Zhang et al. 2004) que Dicer actuaría por la dimerización intramolecular de sus dos dominios RNasa III. El dominio RNasa III se une directamente a la caja PIWI de las proteínas AGO. El dominio dsRBD discrimina entre distintos sustratos de RNA y la consiguiente incorporación de complejos efectores (Margis et al., 2006). El dominio DUF283 parece estar relacionado con la selección de la hebra que será cargada en RISC (Dlakic, 2006). El tamaño de sRNA generado por las diferentes DCLs viene determinado por la longitud y el ángulo de la hélice alfa que conecta los dominios PAZ y RNasa III (Macrae et al., 2006).

En Arabidopsis thaliana se han descrito cuatro proteínas DCL (DCL1-4), con distintas funciones (Xie et al., 2004; Dunoyer et al., 2005; Moissiard et al., 2007; Mlotshwa et al., 2008). DCL1 está asociada a la producción de miRNAs, pero también actúa en la producción de sRNAs derivados de repeticiones invertidas. Las otras tres DCLs están involucradas en distintas rutas de producción de sRNAs. DCL2 genera sRNAs derivados de transcritos antisentido naturales en cis y también está involucrada en la defensa antiviral (jerarquizada por DCL4). DCL3 genera sRNAs implicados en la 
modificación de la cromatina. Finalmente, DCL4 está involucrada en el metabolismo de los tasiRNAs, el silenciamiento postranscripcional y la defensa antiviral (Deleris et al., 2006).

a. DEAD box Helicase C dsRNA bind PAZ RNase III RNase III2 dsrm

b.

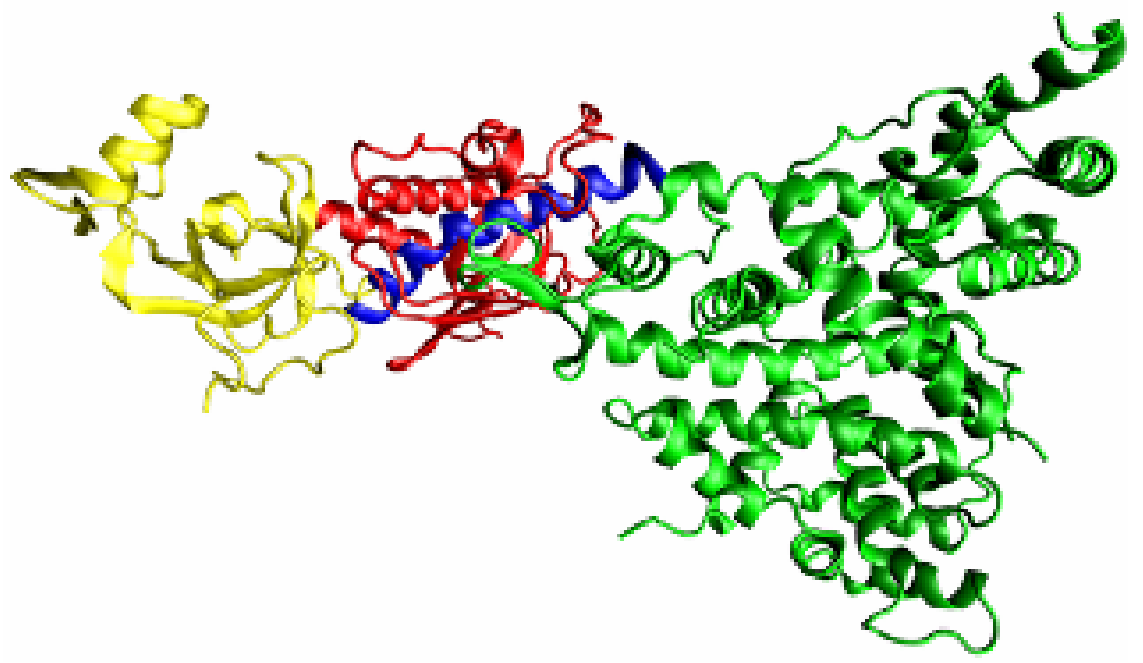

Figura 6. Dominios y estructura de las proteinas Dicer. a) Los seis dominios de las proteinas Dicer. En azul se resalta la helice alfa que existe entre los dominios PAZ y RNasa III, y que determina el tamaño de corte de Dicer. b) Estructura tridimensional de la proteina Dicer de Giardia intestinalis. En amarillo se resalta el dominio PAZ, en azul la hélice conectora, en verde los dominios RNasa III dimerizados, actores del corte de los dsRNA en siRNAs y en rojo el dominio dsrBD, encargado de discriminar entre distintos sustratos de RNA

\subsubsection{Argonauta}

Las proteínas Argonauta (AGO) son el componente catalítico del RISC. El nombre Argonauta les fue acuñado por la similitud del mutante en Arabidopsis thaliana para AGO1 con un pequeño calamar del género Argonauta, y sustituyó a la anterior denominación de Slicer (de to slice, rebanar en inglés) ya que no todas las proteínas AGO promovían el corte de sus mRNAs diana. El término AGO engloba a proteínas de entre 90 y $100 \mathrm{kDa}$, con un dominio variable $\mathrm{N}$-terminal y unos dominios conservados en C-terminal: MID, PIWI y PAZ. El dominio MID une el fosfato presente en 5' del sRNA, mientras que el dominio PAZ reconoce el extremo 3' (Tolia y Joshua-Tor, 2007; Hutvagner y Simard, 2008). El dominio PIWI adopta una estructura plegada similar a la de las RNasas $\mathrm{H}$ y tiene actividad endonucleolítica, contenida en un sitio activo que contiene el dominio Asp-Asp-His (Lin et al., 2010; Rivas et al., 2005). Algunas proteínas AGO cortan sus mRNAs diana en el centro de la secuencia del sRNA o miRNA que contienen en el complejo RISC. No todas las proteínas AGO tienen esta actividad de corte. En Arabidopsis thaliana, por ejemplo, de las 10 proteínas AGO descritas solo 3 (AGO1, AGO4 y AGO7) poseen capacidad de corte confirmada. 
a.

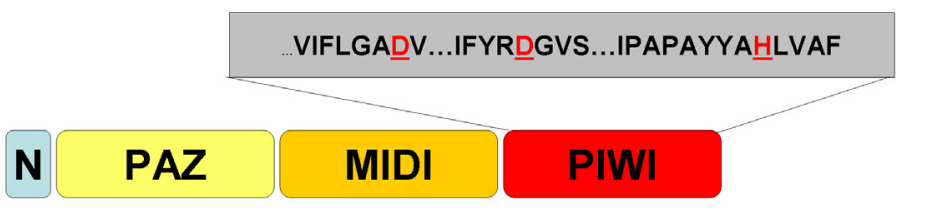

b.

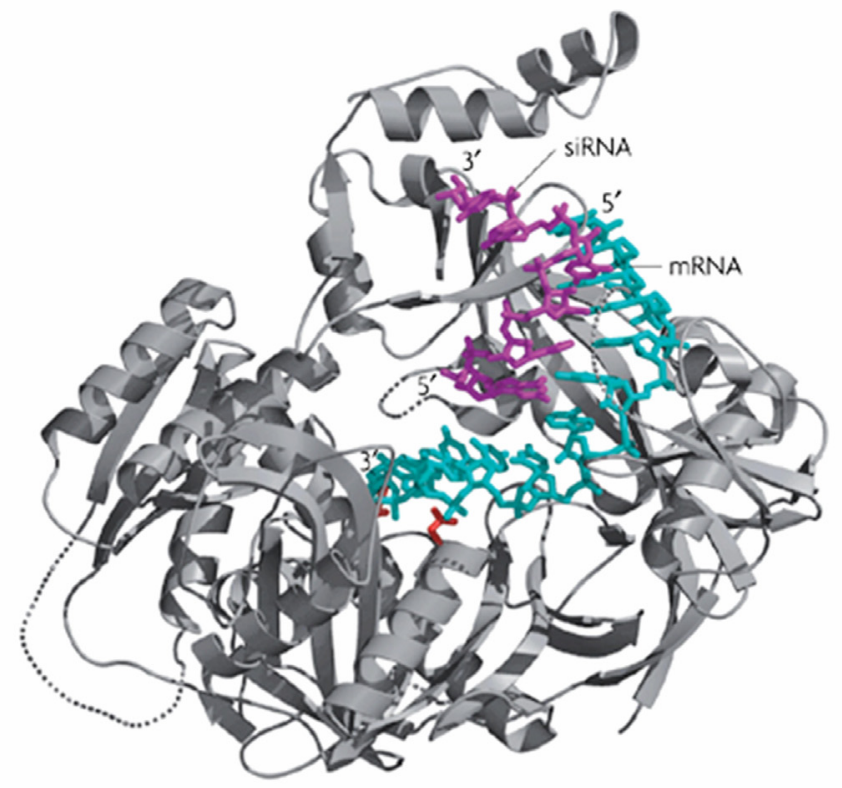

Figura 7. Dominios y estructura de las proteinas AGO. a) Dominios de las proteinas AGO. Se resalta en el cuadro gris la presencia del motivo DDH en el dominio PIWI. b) E $\mathrm{s} t \mathrm{r} \mathrm{u}$ c $\mathrm{t}$ u r a tridimensional de la proteina $\mathrm{AGO}$ de Pyrococcus furiosus. La parte 3' del siRNA (morado) y parte de un mRNA (azul) han sido superpuestos en el modelo. Los residuos activos de PIWI se resaltan en rojo.

\subsubsection{RDRs}

Las enzimas RNA polimerasas dependientes de RNA (RDR) constituyen el centro del mecanismo de amplificación del silenciamiento de RNA y son las responsables de que el inicio del silenciamiento por pequeñas cantidades de moléculas efectoras sea persistente. Estas polimerasas actúan sobre RNAs derivados de virus, transposones, y otros RNAs percibidos por la célula como aberrantes o extraños (Voinnet, 2008). Estudios in vitro con RDRs purificadas a partir de tomate (RDR1) y Arabidopsis (RDR6), demostraron que estas enzimas catalizan la síntesis de un RNA copia (cRNA) a partir de un ssRNA o de un ssDNA, pero no a partir de un dsRNA o un dsDNA (Schiebel et al., 1993; Curaba y Chen, 2008). Las RDRs actúan de forma independiente de secuencia y son muy procesivas. Inician la síntesis de RNAs totalmente complementarios a partir del extremo 3' de sus moldes que permanecen unidos, formando dsRNAs largos in vitro.

Todas las RDRs de plantas comparten una gran homología con la porción Cterminal de RDR2, la cual es suficiente para sus funciones in vitro (Makeyev y Grimes, 2004). El genoma de Arabidopsis thaliana codifica seis RDRs, 3 de las cuales (RDR3a, RDR3b y RDR3c) comparten un motivo aminoacídico DFDGD en el dominio catalítico, 
el cual define un grupo filogenético. Por contra, RDR1, RDR2 y RDR6 comparten el motivo catalítico DLDGD canónico en C-terminal (Wassenegger y Krczal, 2006). Los efectos de las RDRs están íntimamente ligados a las funciones de DCL y AGO. Por ejemplo, la amplificación del PTGS inducido por transgenes y virus por RDR6 requiere de la actividad de DCL4 y AGO1 (Mourrain et al., 2000) mientras que el TGS de transposones y repeticiones en el núcleo por RDR2 necesita de la actividad de DCL3 y AGO4 (Dalmay et al., 2000).

\subsection{Las distintas rutas del silenciamiento de RNA en plantas}

Existen distintas rutas de silenciamiento de RNA en plantas y todas constan de 4 pasos evolutivamente conservados: 1) inducción del silenciamiento por un RNA de doble cadena (dsRNA), 2) procesamiento de dicho dsRNA en moléculas de sRNAs de entre 18 y 25 nucleótidos (nt), 3) metilación 2'-O del sRNA y finalmente 4) incorporación en el complejo efector que se asocia con un RNA o DNA con una homología total o parcial (Ruiz-Ferrer y Voinnet, 2009) (figura 8). Los dsRNAs efectores pueden derivar directamente de la replicación viral, de repeticiones invertidas, de la transcripción convergente de transgenes y transposones o de loci endógenos con una alta estructura secundaria que forman estructuras tipo hairpin. De forma alternativa, el dsRNA puede sintetizarse por la acción de alguna de las RNA polimerasas (RDR1-6) a partir de mRNAs aberrantes (o procedentes del corte por miRNAs) o de transcritos producidos por la RNA pol IV (Brodersen y Voinnet, 2006; Chapman y Carrington, 2007; Ruiz-Ferrer y Voinnet, 2009). En Arabidopsis, el dsRNA se procesa en duplos de sRNAs de un tamaño determinado dependiendo cual de las 4 DCLs actúe. DCL1 genera sRNAs de entre 18 y 21 nts, DCL2 de 22 nts, DCL3 de 24 nts y DCL4 de 21. Este corte es facilitado por 1 de las 5 proteínas de unión a dsRNA (HYL1, DRB2-5) que interaccionan directamente con DCL. Tras este corte los extremos 3' de los sRNAs (extremos con dos nucleótidos no apareados) son O-metilados en 2' por la metiltransferasa HEN1, lo cual los protege de la degradación o de la oligouridilación. Estos duplos de sRNAs estabilizados pueden tener dos destinos: 1) ser retenidos en el núcleo para actuar sobre la cromatina o 2) ser exportados al citoplasma por un homólogo de la exportina-5, HASTY (HST) para iniciar el PTGS. Una de las dos hebras se incorpora a RISC que escaneará la célula buscando ácidos nucleicos de secuencia complementaria sobre los que ejecutará su función que podría ser: 1) corte endonucleolítico en el centro del híbrido sRNA-diana, 2) represión de la traducción 
mediante mecanismos todavía desconocidos y 3) metilación del residuo citosina del DNA o de las histonas con la ayuda de la subunidad b de la Pol IV (NRPD1b) (Baulcombe, 2004; Herr y Baulcombe, 2004; Chapman y Carrington, 2007; Brodersen et al., 2008; Xie y Qi, 2008; Jamalkandi y Masoudi-Nejad, 2009; Ruiz-Ferrer y Voinnet, 2009).

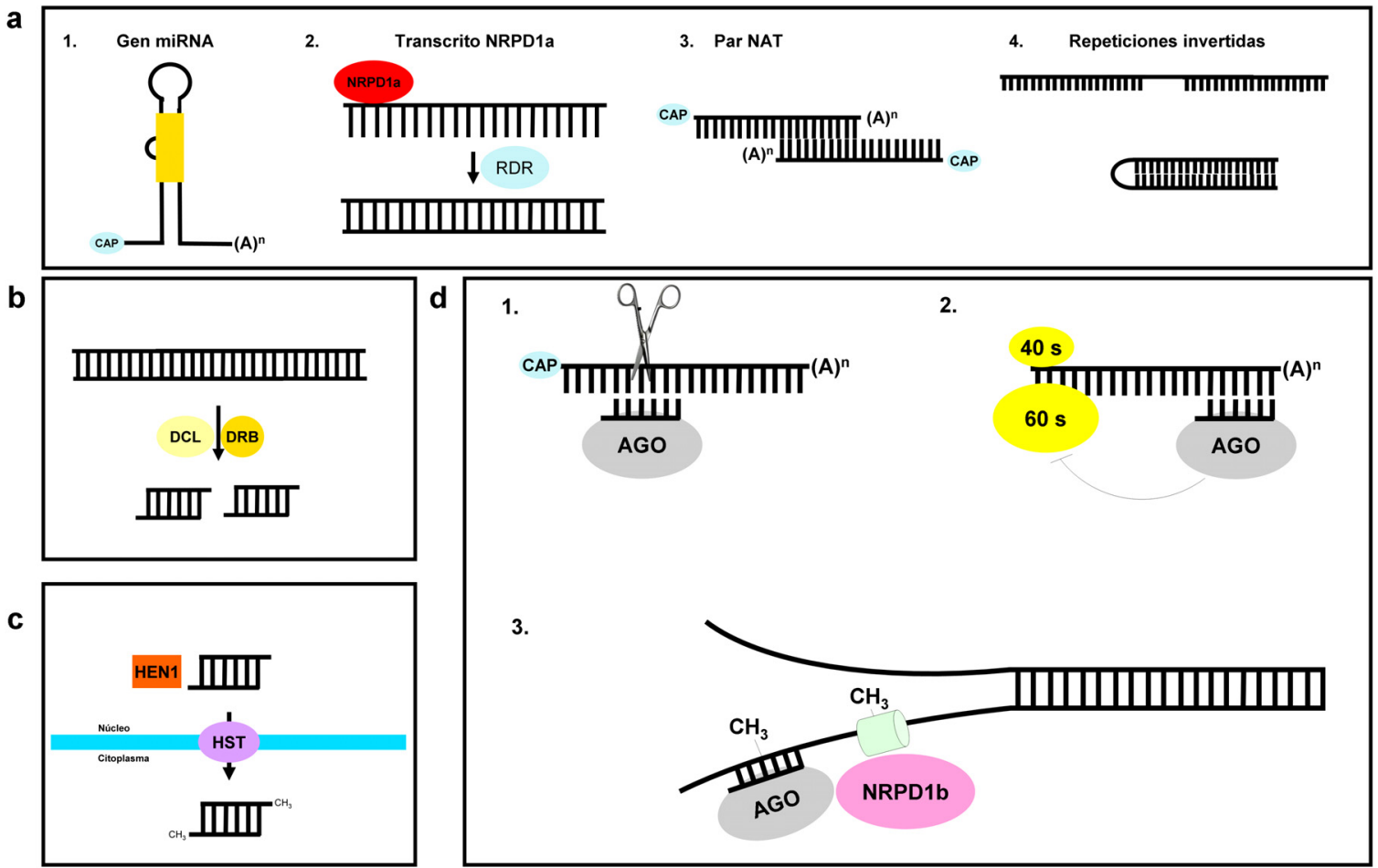

Figura 8. Esquema de los cuatro pasos conservados en la producción de pequeños RNAs. En el bloque a), se representa los distintos orígenes de un RNA de doble cadena: 1) gen de micro RNA, 2) transcrito de la NRPD1a o la RNA polimerasa II amplificado por alguna de las 6 RNA polimerasas RNA dependientes, 3) par de genes NAT que tienen una región de homología entre las que forman un RNA de doble cadena y 4) transcritos con repeticiones invertidas que forman un hairpin. El bloque b) representa la producción de sRNAs por el procesamiento de dicho dsRNA mediante la enzima Dicer-Like acompañada por una proteína de unión a RNA de doble cadena (DRB). El bloque c) representa la metilación de dichos sRNAs producidos en el paso anterior por HEN1 y su exportación al citoplasma desde el núcleo por HST. Finalmente, en el bloque d se representa los distintos destinos de los sRNAs una vez cargados en el complejo efector del silenciamiento (RISC) cuya proteína principal es Argonauta (AGO). Estos destinos pueden ser: 1) corte de mensajeros homólogos en secuencia al sRNA, 2) inhibición de la traducción por mecanismos aun desconocidos y 3) metilación del residuo citosina o de las histonas del DNA (adaptado de Ruiz-Ferrer y Voinnet, 2009).

A pesar de que se ha asumido que el silenciamiento ocurre exclusivamente en el citoplasma, evidencias recientes sugieren que también podría darse en el núcleo en procesos en los que las dianas endógenas no pueden ser reguladas por el PTGS citoplásmico (Hoffer et al., 2011).

Además, en algunos casos, esta interacción sRNA-mRNA diana puede dar lugar a la producción de sRNAs secundarios. En estos casos, el mRNA diana procesado por 
DCL se convierte en dsRNA por RDRs. Este dsRNA es seguidamente procesado por DCL para producir sRNAs secundarios (Allen et al., 2005). No todas las interacciones activan la producción de estos sRNAs. Recientes trabajos señalan que la producción de sRNAs secundarios se inicia únicamente por miRNAs y sRNAs exclusivamente de 22 nts (Cuperus et al., 2010; Chen et al., 2010).

Los avances en las técnicas de secuenciación masiva y clonado de sRNAs han revelado que el set de sRNAs de Arabidopsis se encuentra ampliamente dominado por microRNAs (miRNAs) y por pequeños RNAs interferentes (siRNAs) identificados como ta-siRNAs, nat-siRNAy hc-siRNAs (Rajagopalan et al., 2006; Fahlgren et al., 2007).

\subsubsection{Micro RNAs (miRNAs)}

A diferencia de la mayoría de los siRNAs que actúan en cis sobre el RNA del que derivan (autosilenciamiento), los miRNAs son pequeños RNAs endógenos que ejercen su acción sobre genes distintos de los que proceden (heterosilenciamiento) (Bartel, 2004; Vaucheret, 2006). Los miRNAs Lin-4 y let-7 de C. elegans fueron los primeros en ser descritos, a partir de un análisis de mutantes deficientes en el desarrollo larvario (Lee et al., 1993; Reinhart et al., 2000). El análisis de las secuencias precursoras de estos miRNAs determinó que provenían de un RNA con un apareamiento imperfecto de aproximadamente unos $70 \mathrm{nts}$. Además, el sRNA de $21 \mathrm{nt}$ que producía tenia una complementariedad parcial con la región 3' no traducida (UTR) del mensajero que reprimían (Ambros, 2004; Bartel, 2004; Du y Zamore, 2005; Kim, 2005a, 2005b). El descubrimiento de estos miRNAs sentó las bases para que otros laboratorios clonaran otros sRNAs de entre 21 y 24 nts en distintos organismos. Todos los sRNAs que tenían las características de lin-4 y let-7 (derivados de precursores parcialmente plegados en una estructura tipo horquilla distintos del mRNA sobre el que ejercen su efecto) fueron denominados a nivel colectivo como miRNAs.

En plantas los miRNAs tienen un tamaño que oscila entre 19-25 nts y desempeñan un importante papel biológico al regular funciones tan diversas como el control del desarrollo de la hoja y la flor (Aukerman y Sakai, 2003; Emery et al., 2003; Kidner y Martienssen, 2003; Palatnik et al., 2003; Chen, 2004; Juarez et al., 2004a, 2004b; Baker et al., 2005; Guo et al., 2005), la formación y desarrollo de raíces laterales (Rhoades et al., 2002; Chen, 2005; Zhang et al., 2006), y la respuesta a estreses abióticos tan diversos como salinidad y frío (Sunkar y Zhu, 2004), sequía (Zhao et al., 
2007) o luz ultra-violeta (UV) (Zhou et al., 2007). En general las dianas de los miRNAs incluyen a una gran variedad de factores de transcripción, factores del metabolismo de sRNAs, componentes de la ruta de degradación de proteínas mediada por ubiquitina, genes de resistencia y transcritos no codificantes (Jones-Rhoades y Bartel, 2004; Allen et al., 2005; Rajagopalan et al., 2006; Fahlgren et al., 2007).

La biogénesis de los miRNAs de plantas es ligeramente diferente de la de animales. En ambos reinos los precursores son RNAs transcritos por la RNA polimerasa II (Pol II) en una estructura llamada miRNA primario (pri-miRNA), con extremo cap y poliadenilado. Este pri-miRNA forma una estructura secundaria parcialmente plegada que es procesada para dar lugar a una estructura precursora tipo horquilla (pre-miRNA) de la que serán escindidos los duplex de miRNAs (Kim, 2005b) (figura 9).

A diferencia de lo que ocurre en plantas, los miRNAs de animales suelen estar agrupados en regiones del genoma concretas y son cotranscritos como RNAs policistrónicos (Ambros, 2004; Bartel, 2004; Du y Zamore, 2005; Kim, 2005b; Zhang et al., 2008; Voinnet, 2009). Además, en animales los brazos del pri-miRNAs son cortados por la acción de la RNasa III Drosha, liberando el pre-miRNA que es transportado al citoplasma por Exp5 y cortado por la RNasa III Dicer que libera el duplo de miRNAs (que normalmente se nombra como miRNA/miRNA*) y que tiene dos nucleótidos libres en sus extremos 3', al igual que los duplos de siRNAs. Drosha y Dicer en animales son asistidas en el proceso de corte por proteínas de unión a dsRNA específicas, como por ejemplo Pasha y Loquacious en Drosophila (Ambros, 2004; Bartel, 2004; Du y Zamore, 2005; Kim, 2005). La hebra del duplo con el apareamiento nucleotídico más débil en 5' es seleccionada como miRNA maduro (miRNA en el par miRNA/miRNA*) y cargada en el complejo RISC, mientras que la otra hebra (miRNA*) es degradada (Tomari et al., 2004).

En plantas la estructura genómica de los miRNAs es diferente. Provienen mayoritariamente de precursores individuales y tienen promotores individuales (aunque puede ser que la presencia de miRNAs agrupados en regiones del genoma dependa de la especie, como ocurre en soja) (Zhang et al. 2008; Voinnet 2009). La secuencia de los genes que dan lugar a los miRNAs (genes MIR) comienzan habitualmente con una adenosina localizada $40 \mathrm{nts}$ aguas abajo de una secuencia similar a una TATA box (Xie et al., 2005a). La longitud del pre-miRNA (70-100 nts) suele ser por lo general más larga que en animales. Su biogénesis es también algo diferente: DCL1 tiene las dos funciones (Drosha y Dicer) y actúa en el núcleo (Park et al., 2002; Reinhart et al., 2002; 
Papp et al., 2003; Kurihara y Watanabe, 2004). DCL1 interactúa con HYL1 y la proteína $\mathrm{C} 2 \mathrm{H} 2$ dedos de zinc SERRATE (SE) en unos centros de procesamiento nucleares denominados cuerpos D o cuerpos $\mathrm{SmD} 3 / \mathrm{SmB}$, donde se lleva a cabo la conversión de pri-miRNA a pre-miRNA (Kurihara et al., 2006; Fang y Spector, 2007). La proteína nuclear de unión a RNA DDL, parece actuar también a este nivel, interaccionando con DCL1 para estabilizar el pri-miRNA, aunque su acción parece extenderse a la biogénesis de miRNAs (Yu et al., 2008). El duplo miRNA/miRNA* es metilado por HEN1 (Han et al., 2004; Vazquez et al., 2004; Hiraguri et al., 2005; Yu et al., 2005) y este duplo estabilizado o el miRNA maduro son exportados entonces al citoplasma mediante un ortólogo de EXP5 (HST) (Park et al., 2005) aunque la acumulación de algunos miRNAs no se ve afectada en mutantes $h s t$ por lo que estos deben de ser exportados de alguna manera alternativa (tal vez asociados a AGO1) o tal vez actúen en el núcleo sobre pre-miRNAs como ocurre con el miR162 sobre mRNAs parcialmente cortados de DCL1 en Arabidopsis (Xie et al., 2003; Park et al., 2005). También existen profundas diferencias en el modo de acción entre los miRNAs de plantas y animales, ya que mientras la mayoría de los miRNAs animales reprimen transcripcionalmente sus dianas (desestabilizando la acumulación de mRNAs) (Bagga et al., 2005; Lim et al., 2005), los miRNAs de plantas guían el corte por AGO1 de sus mRNAs diana (Llave et al., 2002; Kasschau et al., 2003).

Es importante destacar que el corte del mRNA diana no es propiedad exclusiva de plantas, ya que por ejemplo el miR196 de ratón procesa el corte del mRNA de HoxB8 presumiblemente por el alto grado de homología entre ambos (Yekta et al., 2004). Normalmente los miRNAs animales forman híbridos imperfectos con su mensajero homólogo en un núcleo central de unos 9-12 nts localizado en múltiples lugares de su región UTR 3'. Este requerimiento poco exigente de homología hace más versátil su acción, pudiendo un solo miRNA tener docenas de dianas.

El miRNA maduro se carga en AGO1 por la unión de su extremo 3' al dominio PAZ. El complejo RISC dirigido por el miRNA busca a su mRNA homólogo mediante un mecanismo de escaneo de helicasa y este mRNA es cortado entre la base 10 y 11 desde el extremo 5' del miRNA (Kidner y Martienssen, 2005). Los fragmentos del mRNA resultantes tras el corte son degradados por la 5'-3' EXORIBONUCLEASE4 (XRN4) en el citoplasma. AGO1 no solamente mediaría el corte del mRNA homólogo al miRNA si no que también reprimiría su traducción (Brodersen et al., 2008). 


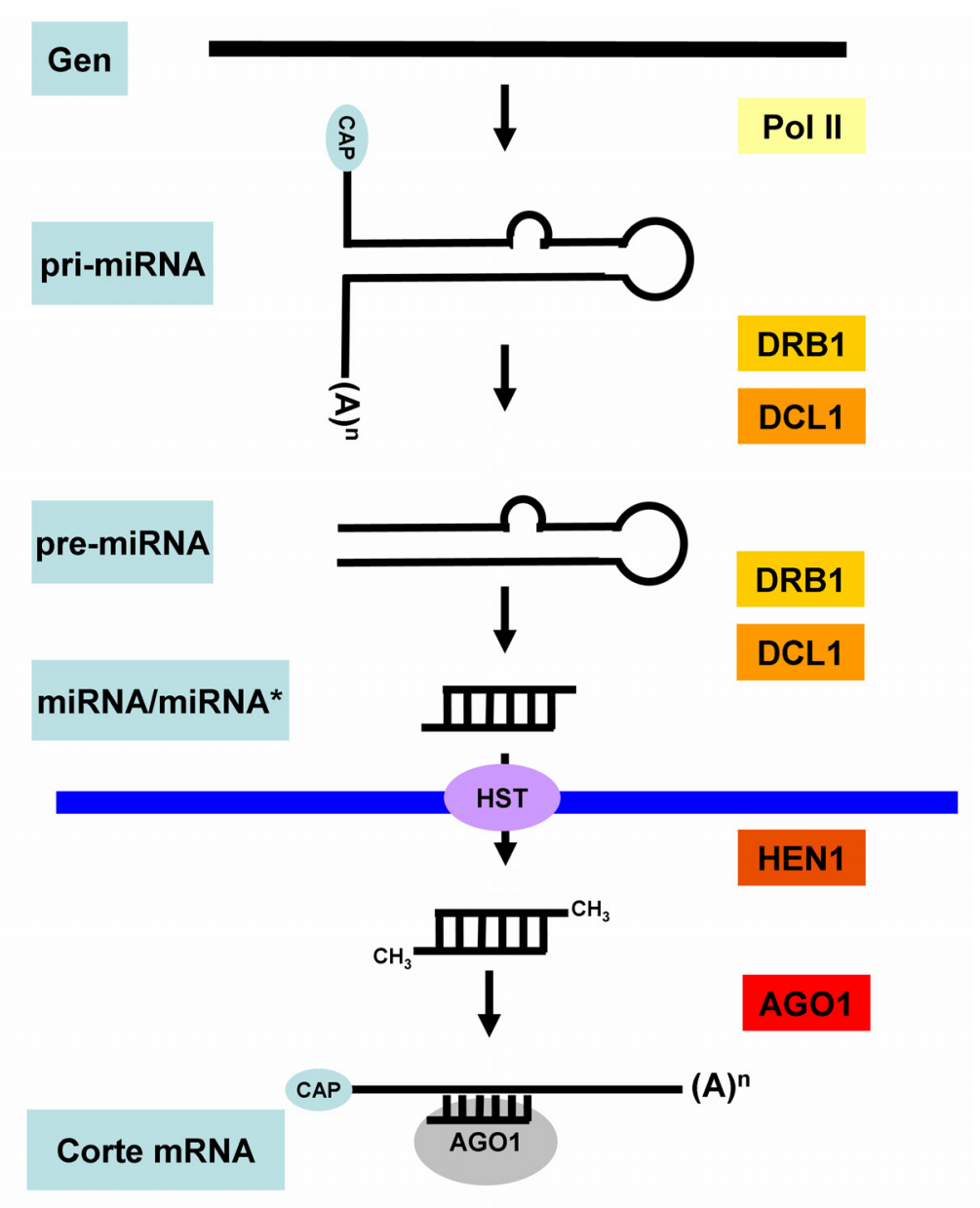

Figura 9. Esquema de la ruta de producción de miRNAs. Los genes de miRNAs tienen promotores individuales. Son transcritos por la RNA polimerasa II (Pol II) en una estructura denominada miRNA primario (primiRNA), que tiene extremo cap y una cola poliadenilada. Este pri-miRNA tiene una estructura secundaria que forma parcialmente un hairpin. De este pri-miRNA es escindido primeramente el precursor de miRNA, y posteriormente el duplo miRNA/miRNA* por la acción de DCL1 junto con DRB1. Este duplo es metilado y exportado al citoplasma donde es cargado en RISC preferencialmente por AGO1 para ejercer su acción sobre un RNA mensajero con una secuencia homóloga a dicho miRNA.

\subsection{2 trans-acting siRNAs}

Los trans-acting siRNAs (ta-siRNAs), al igual que los miRNAs, provienen de loci génicos definidos (loci TAS) sintetizados por la misma maquinaría de la ruta que interviene en la biogénesis de los miRNAs (Vaucheret, 2006). Los genes TAS se transcriben en largos RNAs primarios que no codifican proteínas y cuya única función es ser los precursores de la producción de ta-siRNAs (Peragine et al., 2004; Vazquez et al., 2004; Allen et al., 2005).

La biogénesis de los ta-siRNAs se inicia con la transcripción mediada por la Pol II de los genes TAS. Los RNA generados a partir de los genes TAS son reconocidos y cortados por miRNAs específicos, generando un transcrito aberrante que es reconocido por el complejo RDR6/SGS3 para formar un RNA de doble cadena. Este dsRNA es posteriormente cortado secuencialmente por DCL4 generando un set de siRNAs de 21 nts en fase, a los que se denomina ta-siRNAs (Peragine et al., 2004; Vazquez et al., 2004; Gasciolli et al., 2005; Yoshikawa et al., 2005). Si bien en general se acepta que 
este proceso ocurre en el núcleo (ya que RDR6 y DCL4 tienen localización nuclear), existen evidencias que ponen en duda que la biogénesis de los ta-siRNAs esté restringida exclusivamente a este orgánulo (Hiraguri et al., 2005; Luo y Chen, 2007).

Una vez generados, los ta-siRNAs son reclutados por RISC y median en el silenciamiento de distintos mRNAs, la mayoría de ellos relacionados con el desarrollo de la planta (Peragine et al. 2004; Vazquez et al. 2004) (figura 10).

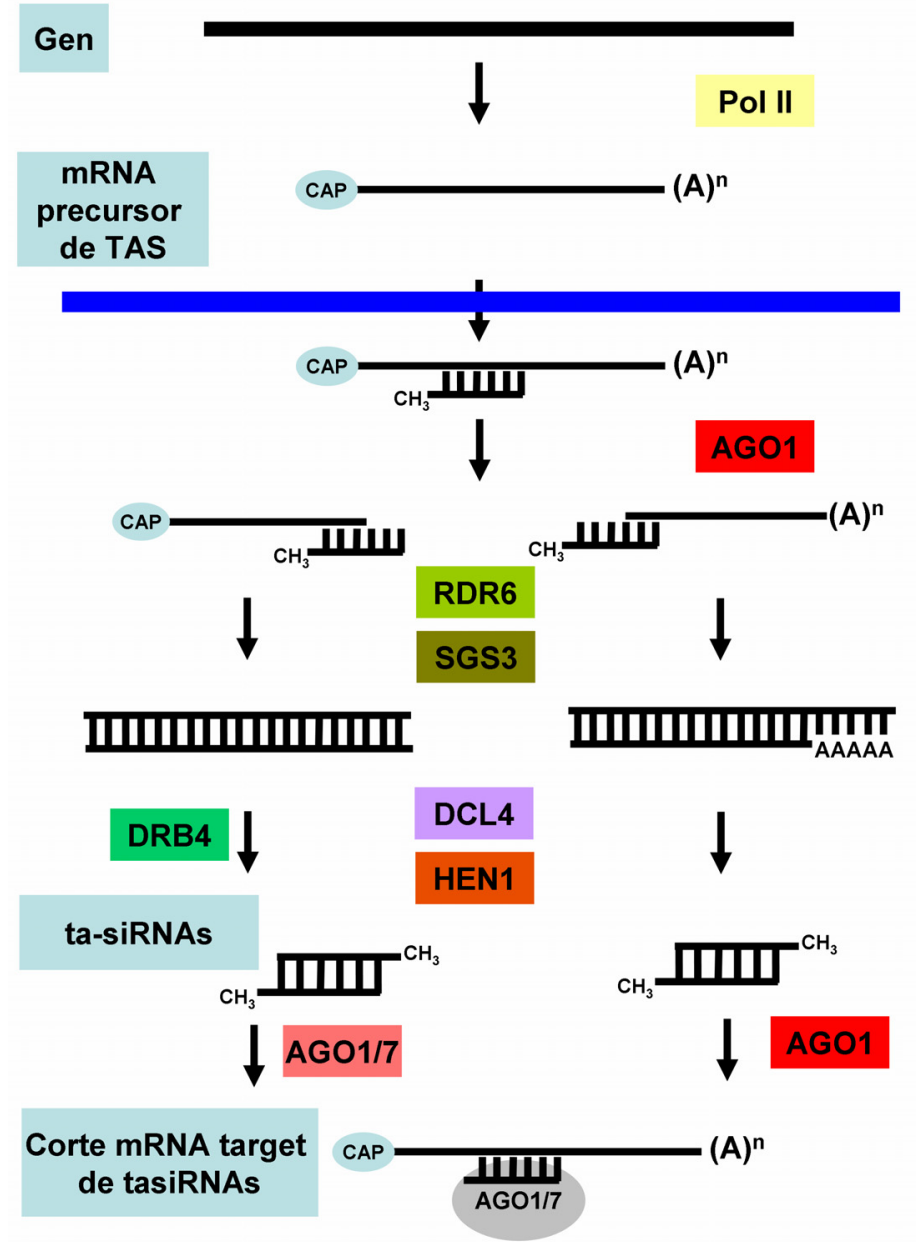

Figura 10. Esquema de la ruta de producción de tasiRNAs. Los ta-siRNAs son sintetizados por la misma maquinaria que los miRNAs. Los genes TAS no codifican proteínas y su unica función conocida es la producción de ta-siRNAs. Los transcritos de los genes TAS contienen dianas de miR N s específicos. Al ser cortados por la acción de AGO1, el transcrito cortado es convertido en un dsRNA por la acción de RDR6 junto con SGS3, tanto la parte que contenía el extremo CAP como la que contenía la cola poliA. Este dsRNA es cortado por DCL 4 produciendo ta-siRNAs en fase de 21 nts. Algunos de estos ta-siRNAs son cargados en algún complejo RISC que actúan sobre algunos mensajeros (totalmente distintos de los genes TAS).

El término trans-acting les fue acuñado por este motivo, sus mRNAs diana son totalmente diferentes tanto en secuencia como en origen al de los genes TAS. En Arabidopsis thaliana se han identificado 8 loci TAS que se agrupan en 4 familias (TAS1-4) (Peragine et al., 2004; Vazquez et al., 2004; Allen et al., 2005; Gasciolli et al., 2005; Xie et al., 2005b; Yoshikawa et al., 2005; Rajagopalan et al., 2006). Las dianas de estos ta-siRNAS son genes que codifican para factores de transcripción de respuesta a auxinas (ARF3-4), proteínas de la familia de repeticiones de pentatricopeptidos (PPR), factores de transcripción MYB y proteínas de función desconocida (Adenot et al., 2006; Fahlgren et al., 2006; Garcia et al., 2006; Rajagopalan et al., 2006). 


\subsection{3 $\mathrm{siRNAs}$ asociados a transcritos naturales antisentido (nat-siRNAs)}

Los transcritos naturales antisentido (NATs) se originan a partir de genes endógenos de la planta, codificantes o no, que comparten una complementariedad de secuencia con otros RNAs. Hay dos subclases cis-NATs y trans-NATs, dependiendo de si la hebra complementaria se encuentra en el mismo locus (cis) o en otro locus del genoma (trans). Los cis-NATs suelen tener una gran complementariedad entre las hebras sentido y antisentido, mientras que los trans-NATs suelen tener una complementariedad no perfecta (Jin et al., 2008).

La biogénesis de los nat-siRNAs se produce en dos fases: una fase de iniciación y una de refuerzo. En la fase de iniciación el dsRNA formado por los transcritos cisantisentido (uno constitutivamente expresado y el otro expresado en respuesta a algún tipo de estrés) es procesado en nat-siRNAs primarios por DCL1 o DCL2. Estos natsiRNAs primarios actúan sobre el transcrito que se expresa de forma constitutiva. La siguiente fase empieza en ese momento, de manera similar a como ocurre con los tasiRNAs (a excepción de la necesidad en la síntesis de nat-siRNAs de la Pol IVa). El transcrito cortado es convertido en dsRNA por la acción del complejo RDR6/SGS3 y procesado por DCL1 para producir un set de siRNAs en fase, nat-siRNAs secundarios. Estos nat-siRNAs secundarios actúan sobre el transcrito constitutivo silenciándolo (figura 11).

El genoma de Arabidopsis contiene al menos mil genes que podrían tener una configuración en antisentido cis (Borsani et al., 2005). Los dos casos estudiados están relacionados uno con estrés abiótico por salinidad (Borsani et al., 2005) y el otro por estrés biótico inducido por una infección bacteriana (Katiyar-Agarwal et al., 2006). La ruta de los nat-siRNAs podría funcionar como un mecanismo de adaptación o protección frente a estreses tanto bióticos como abióticos (Xie y Qi, 2008).

\subsection{4 siRNAs heterocromáticos (hc-siRNAs)}

Los siRNAs heterocromáticos o siRNAs asociados a repeticiones (hc-siRNAs) son siRNAs de 23-25 nts asociados a secuencias genómicas repetitivas tales como transposones, retroelementos, rDNA, repeticiones centroméricas o regiones metiladas del DNA y son con diferencia los sRNAs más abundantes en plantas (Hamilton et al., 2002; Lippman y Martienssen, 2004; Kasschau et al., 2007). 


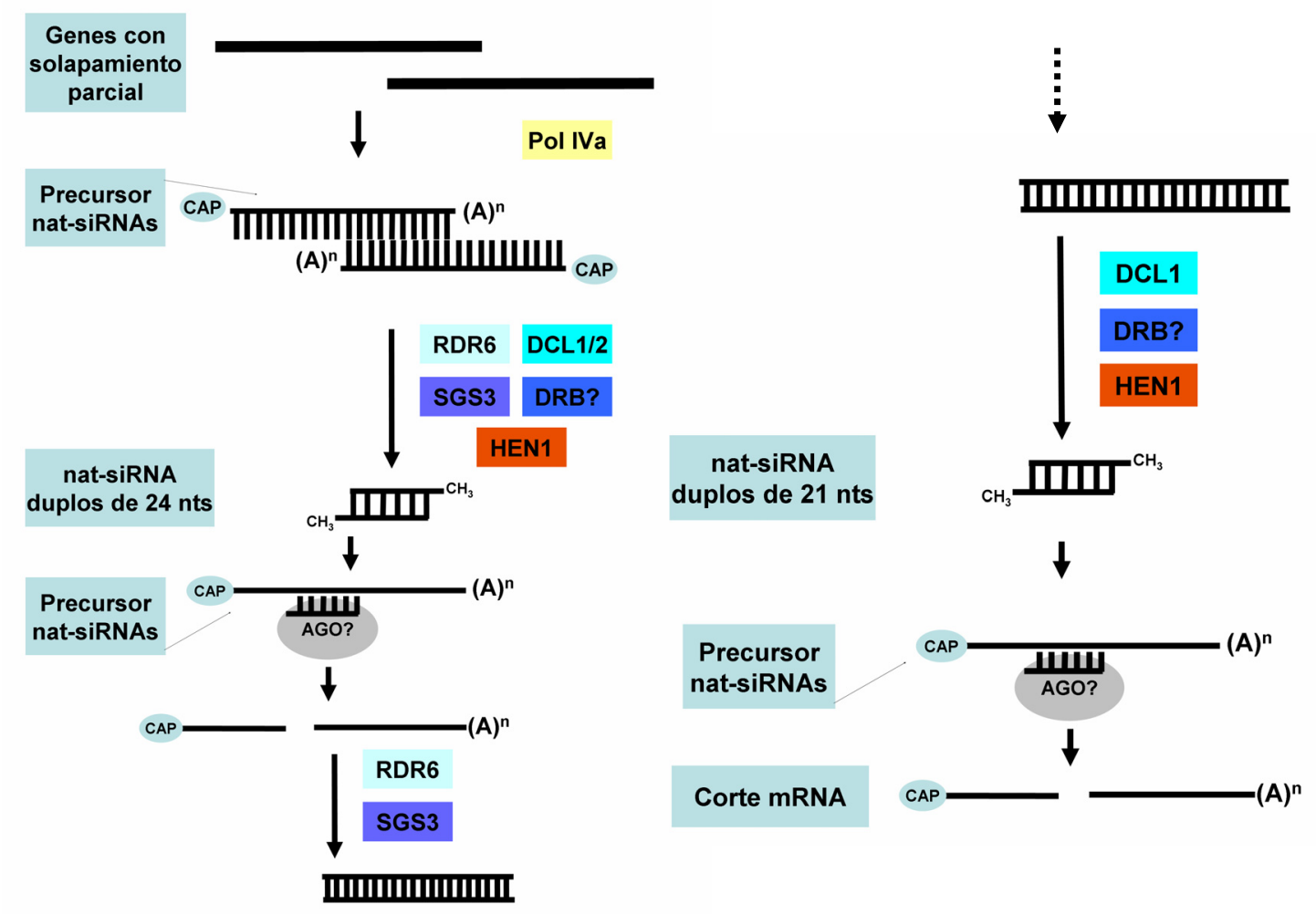

Figura 11. Esquema de la ruta de producción de nat-siRNAs. Los pares NAT son genes endógenos de la planta (codificantes o no) que comparten complementariedad de secuencia. Uno es endógeno y el otro normalmente se expresa asociado a algún tipo de estrés. Su biogénesis se produce en dos fases: 1) iniciación, en la cual el precursor de los nat-siRNAs es procesado por DCL2 o DCL1 en duplos de 21 nts que actúan sobre el gen que se expresa de manera no constitutiva.; 2) refuerzo, el transcrito cortado es amplificado por RDR6 ayudada por SGS3 para formar un dsRNA que es cortado en fase por DCL1 para formar nat-siRNAs secundarios que actúan sobre el transcrito constitutivo silenciándolo.

La biogénesis de estos hc-siRNAs se lleva a cabo en estructuras nucleolares similares a cuerpos de Cajal, e involucra a la Pol IV, la cual parece sintetizar transcritos de RNA no codificantes a partir de loci metilados. También requiere a RDR2, CLSY y DCL3 en su biosíntesis (Hamilton et al., 2002; Xie et al., 2004; Herr et al., 2005; Lu et al., 2005; Onodera et al., 2005). Los hc-siRNAs son cargados en AGO4 o AGO6 para actuar metilando el residuo citosina del DNA o las histonas, uniéndose a transcritos nacientes no codificantes sintetizados por la Pol V y reclutando a diversos factores como DRM2 (una metiltransferasa de novo), DRD1 (un miembro de la SWI2-SNF2 familia de proteínas remodeladora de la cromatina) y DMS3 (una proteína de función desconocida involucrada en el mantenimiento estructural de los cromosomas) (Hamilton et al., 2002; Xie et al., 2004; Herr et al., 2005; Lu et al., 2005; Onodera et al., 2005; Xie y Qi, 2008) (figura 12). 


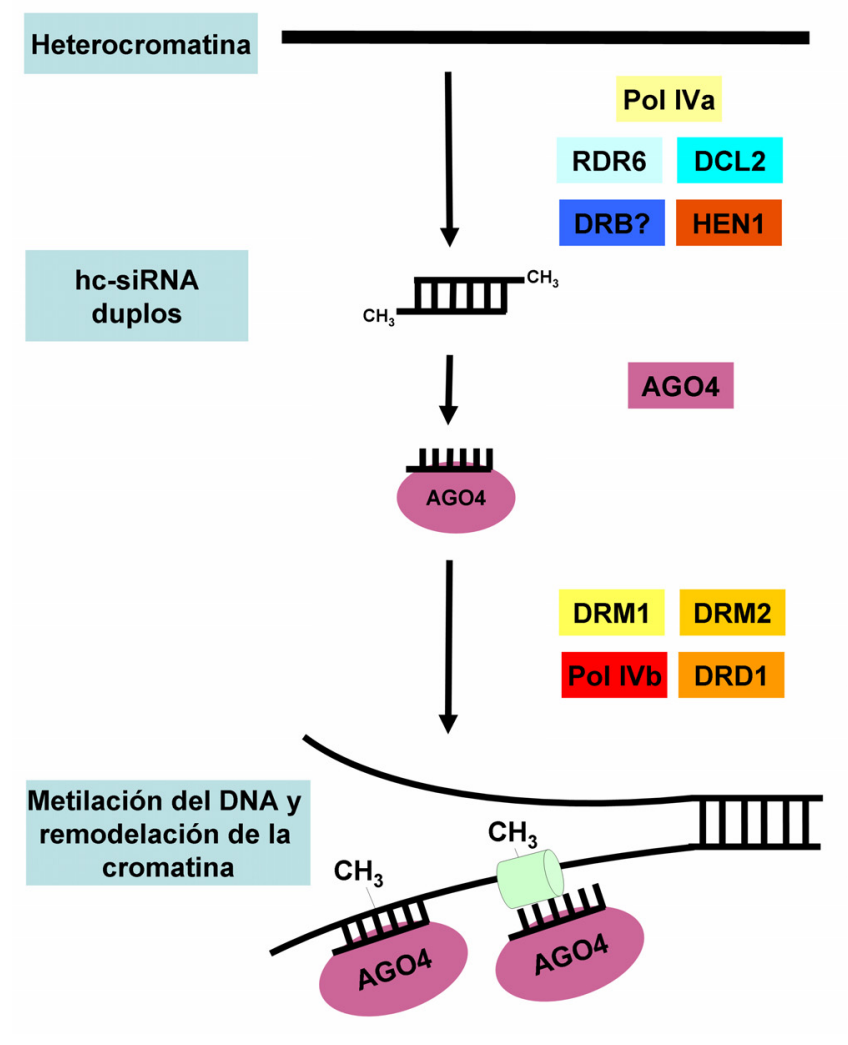

Figura 12. Esquema de la ruta de producción de siRNAs heterocromáticos. Estos siRNAs son producidos a partir de secuencias genómicas repetidas. Se producen por la acción conjunta de la Pol IVa, RDR6, DCL2, DRB y HEN1. Estos siRNAs formados son cargados en AGO4 o 6 y actúan metilando la citosina o las histonas, uniéndose a transcritos nacientes no codificantes sintetizados por la Pol V y recrutando a diversos miembros como DRM2, DRD 1 y D M S 3 .

\subsection{EI movimiento sistémico de la señal de silenciamiento de RNA}

En plantas en general y en algunos organismos en particular (C. elegans) el silenciamiento de RNA no es un evento aislado celularmente. En estos organismos el inicio del silenciamiento en una célula induce el silenciamiento de la misma secuencia en las células circundantes o incluso en todo el organismo.

En plantas, el movimiento sistémico de la señal de silenciamiento fue demostrado por primera vez en Nicotiana benthamiana y Nicotiana tabacum (Palauqui et al., 1997; Voinnet y Baulcombe, 1997). Este silenciamiento era específico de secuencia tanto para un transgén de una secuencia endógena (Palauqui et al., 1997) como exógena (Voinnet et al., 1998). Esta señal también ha sido confirmada en experimentos con injertos, permitiendo una clara separación entre tejido productor de la señal y tejido receptor de distinta naturaleza (Kalantidis, 2004). En plantas se han descrito tres tipos distintos de movimiento de la señal de silenciamiento: corto alcance, silenciamiento local extensivo y sistémico (Kalantidis et al., 2008; Dunoyer et al., 2010b).

La señal de silenciamiento transmisible tanto local como sistemicamente tiene un patrón característico similar al observado para el movimiento viral a través de la planta (Fernandez-Calvino et al. 2011; Pallás et al. 2011). Esta señal se mueve a través 
de los plasmodesmos entre células y por el floema desde tejido fuente hasta tejido sumidero (Voinnet et al., 1998).

Inicialmente se propusieron las proteínas RDR6 y SGS3 como componentes básicos de la transmisión de esta señal (Mourrain et al., 2000; Himber et al., 2003; Schwach et al., 2005). Sin embargo, trabajos posteriores empleando mutantes rdr6 demostraron que la señal de silenciamiento era capaz de moverse 10-15 células más allá del límite del floema. Esta señal era dependiente de DCL4, por lo que se propuso que los sRNAs de 21 nucleótidos asociados a ésta, constituían la señal de silenciamiento (Dunoyer et al., 2005). El modelo resultante proponía que los sRNAs primarios producto de DCL4 formados en células acompañantes eran capaces de moverse 10-15 células fuera del floema, pero requerían la acción de RDR6 para amplificar dicha señal al resto de la hoja. No obstante, este modelo no excluía la posibilidad que otro tipo de RNAs móviles (dsRNAs o RNAs aberrantes) generados en el sitio de inducción del silenciamiento y procesados por DCL4 en las células receptoras de la señal sistémica, pudieran estar involucrados en este fenómeno.

No obstante, la posibilidad de que sean los siRNAs la señal móvil de silenciamiento es una hipótesis que tiene tanto argumentos tanto a favor como en contra. A favor existen argumentos potentes: siempre han sido asociados al silenciamiento, su tamaño es suficiente para promover el silenciamiento específico de secuencia y moverse a través de los plasmodesmos (Mlotshwa et al., 2002). Además, los siRNAs son suficientes para promover el silenciamiento in vitro en Drosophila (Elbashir et al., 2001), cultivos celulares de mamíferos y C. elegans (Caplen et al., 2001; Elbashir et al., 2001). En contra, juega la evidencia de que el supresor del silenciamiento viral helper component-proteinasa (HC-pro) elimina por completo la producción de siRNAs en plantas transgénicas silenciadas para el gen GUS, eliminando el silenciamiento de GUS, pero que al ser usadas como patrón, todavía conserva la capacidad de generar una señal sistémica que induce el silenciamiento de GUS en las plantas injertadas (Mallory et al., 2001).

En un trabajo reciente se ha propuesto que la señal móvil podría estar constituida por siRNAs de doble cadena (Dunoyer et al., 2010b). En este trabajo, los autores rescatan el movimiento de corto alcance desde el floema de la señal de silenciamiento en mutantes $d c l 4$ que expresan DCL4 especificamente en las células acompañantes del floema. Además, usando la técnica de transformación por bombardeo, demuestran que los duplos de sRNAs son capaces de moverse célula a célula y dirigir el silenciamiento 
postranscripcional de los transcritos diana. En otro trabajo paralelo (Molnar et al., 2010), se indica no obstante que posiblemente sean siRNAs de cadena simple la molécula móvil a través del floema. En este trabajo usan microinjertos en raíces mutantes para $d c l 2 d c l 3 d c l 4$, sobre tallos que generan siRNAs para la GFP. La detección de siRNAs derivados del transgén para la GFP en las raíces mutantes indica que estos siRNAs pueden viajar largas distancias a través de la vasculatura en las raices injertadas. Tanto siRNAs primarios como secundarios, de 21-24 nts, se detectaron poniendo de manifiesto que los siRNAs derivados de todas las DCLs son potencialmente móviles. Como además utilizan técnicas de secuenciación masiva, con las que detectan la misma preferencia de acumulación de una hebra del duplo de siRNAs tanto en la raíz como en el tallo, los autores indican que este paso preferencial de una hebra se produce de forma previa a la entrada al floema, y que por tanto la especie móvil a través de la vasculatura es un siRNA de simple cadena que debe moverse unido a AGO u otro complejo proteico. Por otra parte la demostración de movimiento sistémico de ciertos miRNAs (Pant et al., 2008) así como de siRNAs heterocromáticos que se transportan hasta el núcleo reproductivo para reprogramar epigeneticamente el gametofito masculino (Slotkin et al., 2009), sugiere la existencia de una compleja red reguladora coordinando la señalización de este fenómeno.

\section{Interrelación entre patogénesis y silenciamiento de RNA}

Como se ha señalado previamente, el silenciamiento de RNA es una ruta implicada en funciones tanto de defensa frente a ácidos nucleicos invasores como de regulación del desarrollo de la planta. Consecuentemente, y de manera general, la interacción entre planta y patógeno induce la activación de la maquinaria del silenciamiento de RNA a dos niveles: 1) mediante la producción de sRNAs derivados del genoma del patógeno y 2) alterando el patrón de sRNAs celulares causando la modificación de la expresión de reguladores o efectores de las rutas de defensa del hospedador (Ruiz-Ferrer y Voinnet, 2009). Por tanto, cabe esperar una estrecha interrelación entre silenciamiento de RNA y patogénesis (Llave, 2010).

En este apartado se pretende, luego de revisar los antecedentes entre silenciamiento y procesos infecciosos inducidos por distintos patógenos vegetales no viroidales, reseñar y puntualizar las evidencias que sustentan la idea de que el proceso de patogénesis inducido por los viroides podría estar estrechamente relacionado con el mecanismo de silenciamiento de RNA. 


\subsection{EI silenciamiento de RNA y la patogénesis inducida por agentes infecciosos no viroidales}

\subsubsection{Acumulación de sRNAs derivados del patógeno}

Frente a una infección viral las plantas responden induciendo la destrucción de RNAs relacionados con el genoma viral y los genomas virales contrarrestan esta respuesta codificando potentes proteínas supresoras del silenciamiento (Lindbo et al., 1993; Anandalakshmi et al., 1998; Brigneti et al., 1998; Kasschau y Carrington, 1998; Llave et al., 2000). En consecuencia, el éxito de una infección viral depende de un balance entre la respuesta compatible y de defensa del hospedador (Maule et al., 2002). De entre todos los mecanismos celulares de defensa frente a virus, el silenciamiento de RNA es sin duda el más complejo, actuando tanto sobre el genoma del hospedador como sobre el genoma viral (Dunoyer y Voinnet, 2005; Ding y Voinnet, 2007; Llave, 2010).

Los virus activan la maquinaria de silenciamiento a través de la formación de dsRNA viral que puede tener distintos orígenes: 1) formado por las RNA polimerasas virales, 2) apareamiento de las hebras positiva y negativa del virus y 3) apareamiento imperfecto dentro de la propia hebra de simple cadena viral (ssRNA) (Ding y Voinnet, 2007). Además, tres RDRs tienen efecto antiviral a través de su implicación en la producción de vsRNAs, posiblemente por su implicación en la formación de la hebra complementaria negativa (Diaz-Pendon et al., 2007; Donaire et al., 2008; Qi et al., 2009). Los vsRNAs formados tras una infección viral tienen un tamaño comprendido entre 20 y $25 \mathrm{nts}$ y provocan el autosilenciamiento del propio genoma viral (Ding y Voinnet, 2007; Pantaleo et al., 2007). Aunque múltiples AGOs deben de estar presuntamente implicadas en la defensa viral (Zhang et al., 2006) solamente dos (AGO2 y AGO5) han sido implicadas directamente en la unión de vsRNAs (Takeda et al., 2008). El potencial regulador de estas moléculas podría estar relacionado con interacciones funcionales con transcritos del hospedador con grados de homología posiblemente no perfectos, como ocurre con los miRNAs animales (Moissiard y Voinnet, 2006; Qi et al., 2009).

La biogénesis de vsRNAs forma parte de las rutas de formación de siRNAs dependientes de DCL endógenas de plantas (Xie et al., 2004; Gasciolli et al., 2005; Yoshikawa et al., 2005; Bouche et al., 2006). En Arabidopsis DCL4, DCL2 y DCL3 actúan de manera jerárquica para producir vsRNAs de 21,22 y 24 nts respectivamente. 
La inmunidad antiviral depende de los vsRNAs de 21 nts procesados por DCL4, y por DCL2 que actúa en ausencia de DCL4 (Blevins et al., 2006; Bouche et al., 2006; Deleris et al., 2006; Fusaro et al., 2006; Diaz-Pendon et al., 2007; Donaire et al., 2008). Los vsRNAs de $23 \mathrm{nts}$ podrían estar relacionados con la percepción de la señal de silenciamiento a distancia (Brosnan et al., 2007; Diaz-Pendon et al., 2007). Las regiones genómicas de las cuales derivan estos vsRNAs son diversas como han demostrado distintos estudios tanto con virus de RNA como de DNA (Szittya et al., 2002, 2010; Chellappan et al., 2004; Molnar et al., 2005; Moissiard y Voinnet, 2006; Ho et al., 2007; Donaire et al., 2008, 2009; Qi et al., 2009; Coetzee et al., 2010). En teoría, los dsRNAs formados por características intrínsecas de estructura secundaria de las moléculas virales o por sus intermediarios replicativos generaría vsRNAs primarios, en contraste con los vsRNAs secundarios que se formarían por la acción de las RDRs endógenas del huésped (cuya actividad se estimula ante la presencia de RNAs sin controles de calidad como el extremo cap o la cola poliA). En este sentido se ha demostrado que RDR6 y RDR1 (y también los cofactores SDE3 y SGS3) tienen un papel antiviral (Rajagopalan et al., 2006; Diaz-Pendon et al., 2007; Donaire et al., 2008). RDR2 también es necesaria para el silenciamiento de virus de DNA y del virus del cascabeleo del tabaco (TRV) (Raja et al., 2008).

Este complicado escenario de producción de vsRNAs (figura 13) a partir de distintos precursores de dsRNA (ssRNA viral, intermediario replicativo de dsRNA, ssRNA viral amplificado por RDRs) hace difícil distinguir cuales son los verdaderos vsRNAs (primarios o secundarios) importantes en la defensa antiviral. Es posible además que sea cada interacción específica huésped-virus la que cambie el escenario (Ruiz-Ferrer y Voinnet, 2009; Llave, 2010).

\subsection{2 sRNAs endógenos con expresión alterada por patógenos}

Las defensas de plantas contra bacterias, hongos y oomicetos pueden estar asociadas a la inmunidad inducida por patrones de moléculas asociadas a patógenos (PTI) o a la inmunidad inducida por efectores (ETI). En trabajos previos se ha demostrado que existe una estrecha relación entre ETI y la ruta de silenciamiento de RNA mediada por RNAs antisentido (Katiyar-Agarwal et al., 2006). En este trabajo se demuestra que el nat-siRNA/ATGB2 se induce específicamente por el reconocimiento del efector AvrPt2 de Pseudomonas syringae por la proteína de resistencia de Arabidopsis (R) RPS2. Este nat-siRNA deriva del solapamiento parcial del gen de una 
proteína similar a Rab2 de unión a GTP pequeña (ATGB2) y del gen de una proteína similar a repeticiones de pentatricopéptidos (PPRL) expresada constitutivamente y parece requerir la inducción transcripcional causada por ATGB2 a través de un mecanismo que involucra a la proteína de membrana NDR1. La biogénesis de natsiRNAATGB2 requiere de DCL1, HYL1, HEN1, RDR6, SGS3 y la subunidad NRPD1a de la RNA Pol IV.

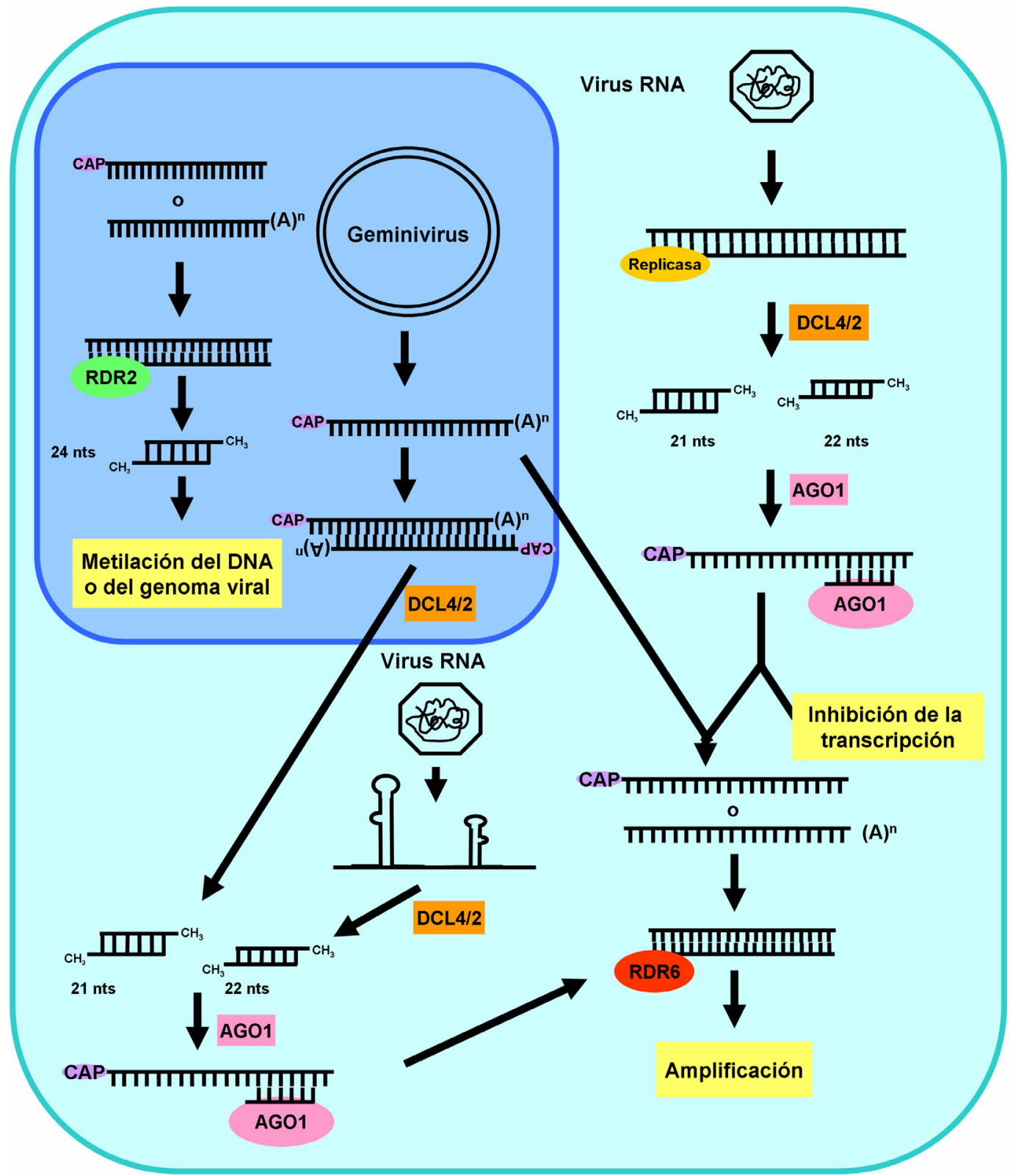

Figura 13. El silenciamiento antiviral en Arabidopsis thaliana. Esquema de los procesos conocidos de actuación del silenciamiento génico en defensa antiviral en A.thaliana. Los vsRNAs primarios pueden tener distintos orígenes. En el caso de virus de RNA por procesamiento sobre su intermediario replicativo o su ssRNA. La producción de vsRNAs secundarios se produce a través de la amplificación del transcrito viral cortado por los vsRNAs primarios o por los restos de estos que carecen de controles de calidad. Finalmente los vsRNAs derivados de virus de DNA provienen de la transcripción de estos o de sus ssRNAs exportados al citoplasma. Cabe señalar que hay un proceso de metilación que sufren estos virus en el núcleo (Adaptado de Ruiz-Ferrer y Voinnet, 2009). 
También se ha demostrado que un siRNA atípico en su tamaño (denominados largos [1siRNAs] de 39-40 nts) se acumula en Arabidopsis por estreses bióticos. Este 1sRNA (lsRNA-1) es específico de la resistencia mediada por RPS2 y su biogénesis también depende de un par de transcritos NAT en los cuales la inducción del transcrito de una kinasa similar a un receptor (RLK) requiere la activación por RPS2 por el efector bacteriano AvrPt2. El otro transcrito que forma el par NAT es la región 3'-UTR del transcrito antisentido RAP (Katiyar-Agarwal et al., 2007). El proceso de biogénesis del lsRNA-1 se completa por la acción de DCL4, AGO7 y NRPD1b.

En lo que a miRNAs respecta, el miRNA 393 (miR393) de Arabidopsis fue el primer sRNA implicado en la respuesta PTI bacteriana por Pseudomonas syringae. El transcrito de este miRNA se induce por el péptido PAMP derivado de la flagelina, flg22, y reprime la señalización por auxinas (Navarro et al., 2006). Además del miR393, otros tres miRNAs parecen sobre-expresarse en plantas infectadas por bacterias: miR160, miR167 y miR825 (Fahlgren et al., 2007). La sobre-expresión de este mismo miRNA, miR393, se ha relacionado también con la infección de una raza oncogénica de Agrobacterium tumefaciens (Pruss et al., 2008). Además, en tumores inducidos por esa misma raza, se sobre-acumula tanto el miR393 como el miR167. Otro miRNA, miR398, se reprime como consecuencia de la infección por dos razas de Pseudomonas syringae avirulentas (cada una con el efector avrRpm1 y avrRpt2) pero permanece sin alteración por la infección de la raza virulenta Pst DC3000 (Jagadeeswaran et al., 2009).

Alteraciones en los niveles de miRNAs endógenos de plantas se han asociado también a distintas infecciones virales. El análisis de las variaciones en la población de miRNAs en plantas de Nicotiana benthamiana infectadas por 5 virus diferentes (TMV, virus del mosaico del tomate [ToMV], virus del grabado del tabaco [TEV], virus Y de la patata $[\mathrm{PVY}]$ y virus $\mathrm{X}$ de la patata $[\mathrm{PVX}]$ ) demostró que el proceso infeccioso inducía la acumulación de los miRNAs 156, 160, 164, 166, 169 y 171 (Bazzini et al., 2007). Esta alteración en los niveles de acumulación de los distintos miRNAs era independiente de la actividad supresora del silenciamiento viral, sugiriendo que los virus analizados podrían explotar la vía de los miRNAs para inducir en la planta infectada alteraciones asociadas al proceso de patogénesis (Bazzini et al., 2007). De manera similar, se ha descrito que dos miRNAs, bra-miR158 y bra-miR1885, se sobreexpresan en plantas de Brassica rapa infectadas por el virus del mosaico del nabo (TuMV). La sobre-expresión de estos miRNAs resultó además ser muy específica ya 
que ni la infección por el virus del mosaico del pepino (CMV), el virus del mosaico del tabaco (TMV) o el hongo Sclerotinia sclerotiorum afectaron a los niveles de estos dos miRNAs. La predicción de la diana de bra-miR1885 revela que es un miembro de la clase TIR-NBS-LRR de proteínas de resistencia a enfermedades (He et al., 2008). Recientemente se ha descrito un incremento en el nivel de actividad transcripcional del promotor del miRNA 164 a en una infección con el virus del mosaico de la colza (ORMV) (Bazzini et al., 2009) . La infección con CMV de plantas de tomate también induce la acumulación de una serie de miRNAs $(162,164,165$ y 168) que es específica de la cepa viral (Cillo et al., 2009). Por último, cabe destacar que recientemente se ha demostrado por primera vez la interacción entre un vsRNA de 22 nucleótidos derivado del genoma del RNA satélite Y del virus del mosaico del pepino (CMV) con su diana, el RNA mensajero de la subunidad I de la Mg protoporfirín quelatasa del huésped natural de CMV Nicotiana tabacum (Shimura et al., 2011; Smith et al., 2011).

\subsection{La relación entre silenciamiento de RNA y la patogénesis inducida por viroides}

Al igual que para el resto de funciones, los viroides son estrictamente dependientes de su interacción con factores del huésped para inducir síntomas. Los mecanismos implicados en la patogénesis viroidal son en general desconocidos. Originalmente se propuso que la simple competencia por los factores celulares implicados en la transcripción, el movimiento célula a célula y/o el movimiento sistémico podrían ser la clave de este proceso. Sin embargo, la falta de evidencias experimentales que sustenten este supuesto, ha ido restando credibilidad a esta idea (Conejero, 2003; Tabler y Tsagris, 2004; Flores et al., 2005; Owens y Hammond, 2009). Ante este hecho emerge un paisaje mucho mas complejo para la patogénesis viroidal que involucra principalmente las desregulación de la expresión génica de la planta inducida por la interacción entre el RNA viroidal y factores o procesos metabólicos del huésped (Ding, 2009). En este escenario y ante la evidencia de que los viroides son inductores del silenciamiento de RNA, emerge con cada vez mas fuerza la idea de que el proceso de patogénesis asociados a las infecciones viroidales podría estar total o parcialmente relacionado con este mecanismo regulador mediado por RNAs. En este sentido cabe destacar que una de las primeras aproximaciones de las relaciones viroidehuésped orientada hacia su relación con el silenciamiento de RNA condujo al descubrimiento del proceso de metilación de DNA mediada por RNA (Wassenegger et al., 1994). 


\subsubsection{Los viroides inducen la acumulación de sRNAs derivados de su genoma.}

Mediante estudios de hibridación una extensa serie de trabajos demostraron que las infecciones ocasionadas por viroides miembros de ambas familias (Pospiviroidae y Avsunviroidae) estaban asociados a la presencia de sRNAs de origen viroidal (vdsRNAs). Pequeños RNAs del tamaño esperado, (entre 20 y 25 nts) y derivados del patógeno fueron detectados en distintas especies vegetales infectadas por PSTVd (Itaya et al., 2001; Papaefthimiou et al., 2001), PLMVd (Martinez de Alba et al., 2002), CChMVd (Martinez de Alba et al., 2002), ASBVd (Markarian et al., 2004), CEV (Markarian et al., 2004) y HSVd (Gomez and Pallas, 2007). Estos estudios aportaron las primeras evidencias que sugerían que los viroides inducían en la planta huésped una respuesta relacionada al silenciamiento de RNA.

\subsubsection{Características y biogénesis de los vd-sRNAs.}

Los vd-sRNAs detectados en las plantas infectadas, presentaban el tamaño típico de los sRNAs procesados por DCLs, entre 20 y 24 nts (Itaya et al., 2007; Machida et al., 2007; Martin et al., 2007; St-Pierre et al., 2009), y además (al menos en el caso de los sRNAs derivados del CEVd), poseían un grupo fosfato en su extremo 5' y estaban metilados en su extremo 3' (Martin et al., 2007). Estas evidencias, si bien sugerían de manera indirecta la participación de DCLs en la generación de los vd-sRNAs, no permitían identificar de manera inequívoca a los componentes de la maquinaria de silenciamiento de RNA implicados en la biogénesis de vd-sRNAs.

Teniendo en cuenta que la planta modelo en biología molecular de plantas, Arabidopsis thaliana, no es huésped natural ni experimental de ningún viroide, lo que impide el uso de mutantes defectivos para las distintas DCLs, la caracterización de los componentes implicados en la biogénesis de los vd-sRNAs pasaba necesariamente por el clonado y secuenciación de estos sRNAs.

Las primeras aproximaciones en este sentido realizadas mediante técnicas convencionales de secuenciación a baja escala si bien permitieron comenzar a definir el mapa poblacional de los vd-sRNAs generaron datos confusos e incluso algunas veces contradictorios sobre los factores implicados en su biogénesis. En este sentido la caracterización de los sRNAs derivados de PSTVd confirmaron que los vd-sRNAs tenían un tamaño comprendido entre 20 y 24 nts, indicando que todas las DCLs estarían implicadas en su producción (Itaya et al., 2007; Machida et al., 2007). Un rango de 
tamaño similar (20-24 nts) se describió para los sRNAs derivados del CEVd, con una acumulación mayoritaria de vd-sRNAs de 21 y 22 nts, lo que sugería una acción preponderante de DCL1/DCL4 y de DCL2 (Martin et al., 2007). Por último, en el caso de infecciones con PLMVd la mayoría de vd-sRNAs recuperados fueron de $21 \mathrm{nts}$ lo que podía interpretarse como producidos principalmente por DCL1 o DCL4 (St-Pierre et al., 2009). Es importante destacar, que en todos los casos los autores reconocían la posibilidad de que los datos obtenidos pudieran estar sesgados por artefactos en los métodos de secuenciación empleados (a baja escala) y coincidían en sugerir el empleo de aproximaciones más sensibles y masivas (sistemas de secuenciación masiva) para poder confeccionar una mapa más exacto de la diversidad y representatividad de los sRNAs asociados al proceso de infección por viroides.

Si bien en ese momento el conocimiento sobre los factores celulares implicados en la biogénesis de los vd-sRNAs era limitado, cabe destacar que la situación era aun peor cuando lo que se trataba de determinar cual de las formas biológicas del viroide actuaba como precursor principal de los vd-sRNAs. Los viroides maduros son moléculas circulares con una alta estructura secundaria, por lo que podrían comportarse como dsRNAs y potenciales sustratos de DCL. No obstante, también podrían serlo sus intermediarios replicativos o la amplificación de éstos por la acción de RDRs celulares.

En estudios previos se había demostrado que las formas maduras de PSTVd y ASBVd eran resistentes a la actividad de DICER humana (Chang et al., 2003). Sin embargo, existían evidencias de que regiones estructuradas del RNA genómico de PLMVd y PSTVd, incubados con extractos de germen de trigo y de Arabidopsis respectivamente, podían actuar como sustratos de una o mas DCLs (Landry y Perreault, 2005; Itaya et al., 2007). Esta suma de resultados contradictorios aportaba más confusión que claridad a la situación. Por otra parte, los resultados obtenidos por secuenciación convencional de vd-sRNAs, no ayudaban de ninguna manera a resolver este problema. Estudios iniciales con PSTVd y CEVd sugerían que los vd-sRNAs derivaban principalmente de forma maduras debido a la acumulación principal de vdsRNAs de secuencia positiva (Itaya et al., 2007). Sin embargo, un trabajo publicado simultáneamente describía que la mayoría de los vd-sRNAs asociados a la infección con PSTVd eran de polaridad negativa lo cual indicaría que derivarían de la cadena negativa de los intermediarios replicativos (Machida et al. 2007). Además, todos estos trabajos coincidían en sugerir una preferencia en la actividad de DCL en ciertas regiones del RNA viroidal tal vez relacionado con una mayor estructura secundaria de las mismas. 
Así, estos datos dibujan un difuso retrato sobre la biogénesis de vd-sRNAs en la que teóricamente podrían darse diversas situaciones (figura 14). Por una parte, en los miembros de la familia Pospiviroidae, las moléculas maduras del viroide podrían ser sustrato de DCL4/DCL2 para dar lugar a vd-sRNAs primarios en su tránsito por el citoplasma. Pero también los intermediarios replicativos o la molécula madura podrían dar lugar a estos vd-sRNAs en el núcleo por la acción de DCL1. También podría ocurrir que los vd-sRNAs primarios fueran usados como cebadores sobre los intermediarios replicativos de simple cadena, ser amplificados en el citoplasma por RDR6 y usar los dsRNAs como sustratos para las DCLs citoplásmicas. Los vd-sRNAs derivados de los miembros de la familia Avsunviroidae deberían derivar necesariamente de la acción de DCLs citoplásmicas, ya que no se han descrito DCLs con localización cloroplástica.

\subsubsection{Efecto de los vd-sRNAs sobre las moléculas viroidales.}

Por analogía a lo que ocurre con los virus de plantas, cabría esperar que los vdsRNAs actuaran como verdaderos siRNAs guiando a RISC para degradar los RNAs viroidales. Este resultó ser otro aspecto controvertido del ciclo de vida de los viroides con trabajos aportando resultados contradictorios y polarizados en un sentido y otro de esta teoría.

Algo que queda totalmente claro es que a pesar de la acumulación de vd-sRNAs, los viroides son capaces de acumularse en altas cantidades en la planta infectada (Itaya et al., 2001). En un principio, esta observación se relacionó con su alta tasa de replicación, una compartimentalización en orgánulos celulares aislados de la maquinaria de silenciamiento o por asociación con proteínas del huésped (Chang et al., 2003; Vogt et al., 2004; Flores et al., 2005). No obstante, los últimos descubrimientos parecen apuntar en la dirección de que las formas maduras del viroide serían resistentes a la degradación mediada por silenciamiento de RNA (Wang et al., 2004; Gomez y Pallas, 2007; Itaya et al., 2007; Elena et al., 2009). Esta repuesta de los viroides al silenciamiento podría estar basada en dos situaciones distintas : 1) el viroide es susceptible al corte por DCLs pero resistente a la degradación por RISC, gracias a su compacta estructura secundaria o 2) los vdsRNAs no son funcionales silenciando al RNA viroidal (Ding, 2009).

Los viroides, al contrario que los virus, no codifican ninguna proteína inhibidora del silenciamiento. En consecuencia, diversos estudios sugieren que al igual que lo observado en ciertos virus animales (Gitlin et al., 2005; Westerhout et al., 2005) su 
estructura secundaria sería resistente a la degradación mediada por RISC (Wang et al., 2004; Elena et al., 2009; Gomez et al., 2009). Esta sugerencia ha sido demostrada para PSTVd (Itaya et al., 2007) y para HSVd (Gomez y Pallas, 2007). Además, plantas de tomate infectadas con PSTVd se recuperan en estados tardíos de la infección, pero no obstante siguen acumulando PSTVd en gran cantidad (a diferencia de lo que ocurre en virus). Curiosamente las hojas recuperadas de la infección acumulan mayor cantidad de vd-sRNAs de 24 nts, mientras que en estadíos tempranos de la infección se acumulan en mayor cantidad los de $21 \mathrm{nts}$ (Machida et al., 2007).

Respecto a la falta de actividad de los vd-sRNAs se ha demostrado que sRNAs derivados de PSTVd son activos en la degradación de secuencias de RNA introducidas artificialmente con secuencias diana para esos vd-sRNAs (Vogt et al., 2004) y que secuencias derivadas de PSTVd, alteran el desarrollo de plantas de tomate simulando la sintomatología de una infección viroidal (Wang et al., 2004).

Recientemente Gomez y Pallás (2007), han utilizado una construcción delatora (secuencia de HSVd fusionada a la GFP) y plantas de Nicotiana benthamiana transgénicas para HSVd (que acumulan formas maduras del viroide y vd-sRNAs) para estudiar el efecto de los sRNAs derivados de HSVd sobre el genoma del viroide. Cuando el transcrito delator es expresado transitoriamente sobre el fondo $\mathrm{Nb} / \mathrm{HSVd}$ se observó que los vd-sRNAs inducían la degradación de las secuencias homólogas de HSVd sin estructura secundaria fusionadas en el gen delator. Sin embargo, en este ambiente con la actividad de silenciamiento específico contra HSVd, las formas maduras del viroide son capaces de escapar del silenciamiento, salir de la célula, traslocarse sistémicamente e inducir la infección en injertos no transgénicos.

Si bien estos resultados sustentan la idea de que los vd-sRNAs son funcionales y que la capacidad de los viroides de evadir el silenciamiento reside en su compacta estructura secundaria, un par de estudios publicados (Carbonell et al., 2008; Schwind et $a l ., 2009)$ recientemente generan controversia al respecto. En uno de estos trabajos se describe que la expresión transitoria de altas concentraciones de dsRNA de PSTVd, CEVd y CChMVd en plantas inhibe la infección viroidal en sus estadíos iniciales de manera específica de secuencia (Carbonell et al., 2008). Por otra parte, se ha descrito que plantas transgénicas que expresan constitutivamente una secuencia tipo horquilla de PSTVd muestran una resistencia parcial a una infección por PSTVd (Schwind et al., 2009). No obstante, en estos trabajos no se ha demostrado que esta interferencia en el 
proceso de infección estuviera relacionada con la susceptibilidad de las formas maduras de los viroides al silenciamiento de RNA.

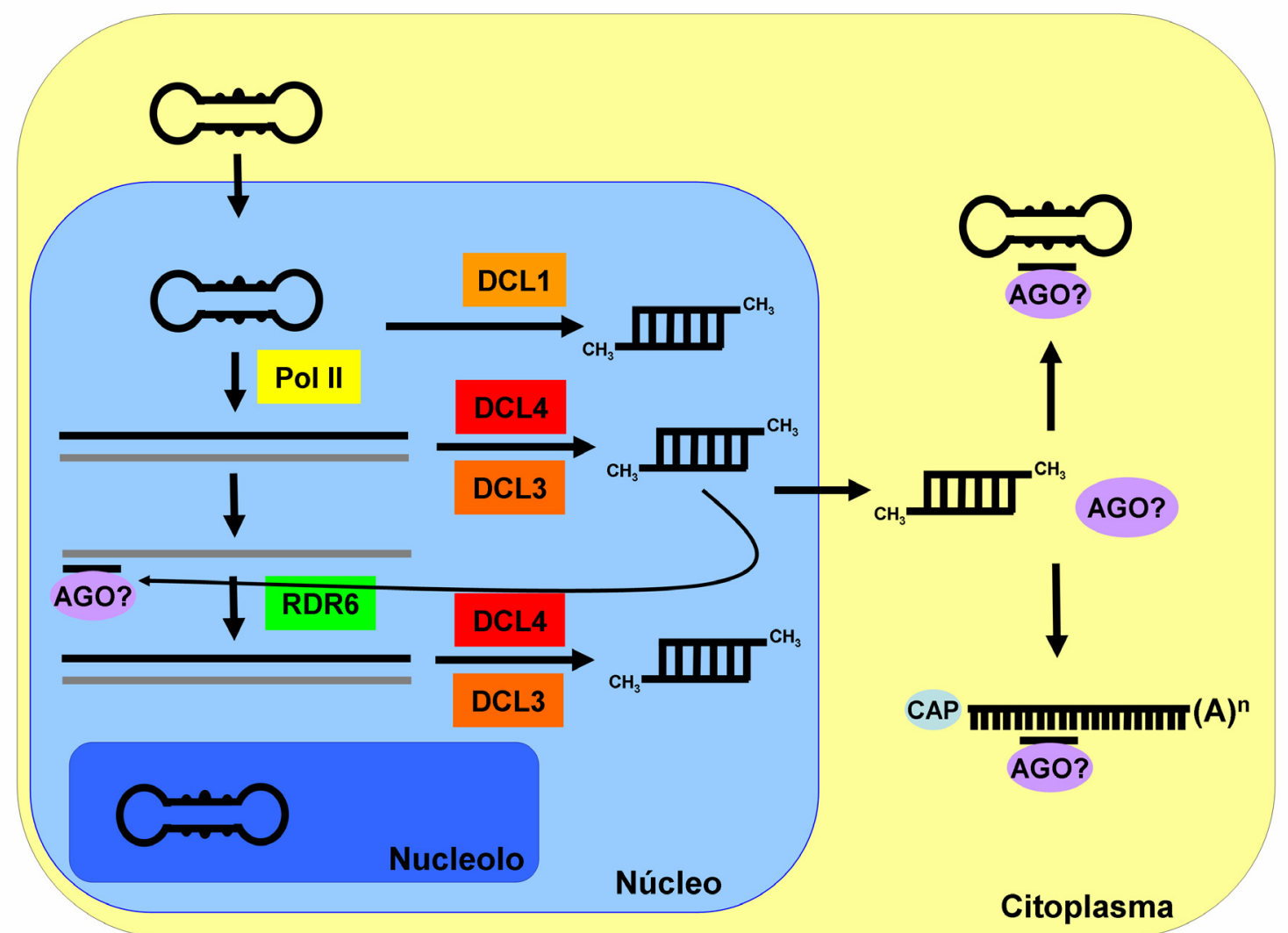

Figura 14. Distintas posibles rutas para explicar la producción de vd-sRNAs en los viroides de la familia Pospiviroidae. Los datos actuales no pueden explicar ninguna ruta en exclusividad. El viroide podría ser efecto de múltiples DCLs. Podría explicarse tanto la producción de vd-sRNAs a partir de la molécula madura, intermediarios replicativos, o la amplificación por RDR6 de un ssRNAviroidal. El destino de los vdsRNAs podría ser tanto su acción a modo de miRNAs contra un mRNA endógeno como sobre la propia molécula viroidal.

\subsubsection{Los vd-sRNAs y su relación con la patogénesis.}

Considerando las infecciones de origen viral, la relación entre el proceso de patogénesis y los sRNAs derivados de la molécula viral puede explicarse por dos vías distintas. Por una parte, en el caso de los virus de plantas que codifican supresores del silenciamiento, por la interacción de estas proteínas reguladoras con las rutas de producción de miRNAs y sRNAs endógenos claves para el desarrollo del huésped (Kasschau et al., 2003), o bien, en el caso de los virus de DNA de animales por la acción específica de ciertos miRNAs codificados en su genoma sobre algunos mRNAs celulares (Cullen, 2006).

Teniendo en cuenta estos antecedentes, se ha propuesto que análogamente a lo que ocurre con miRNAs derivados de los genomas de virus animales, los vd-sRNAs podrían actuar como miRNAs o algún otro tipo de sRNA endógeno y dirigir la 
degradación o inhibir la traducción de mRNAs del huésped, causando la aparición de síntomas (Papaefthimiou et al., 2001; Conejero, 2003; Markarian et al., 2004; Wang et al., 2004). Otra alternativa a considerar es que los vd-sRNAs podrían dirigir la metilación de regiones de DNA del huésped y alterar la expresión de ciertos genes (Pelissier y Wassenegger, 2000).

En este sentido se ha demostrado que durante el proceso infeccioso PSTVd y ASBVd acumulan vd-sRNAs de forma proporcional a la sintomatología que inducen (Itaya et al., 2001; Markarian et al., 2004). Por otra parte, un elegante estudio realizado en tomate muestra que la expresión de síntomas en plantas transgénicas que expresan repeticiones invertidas incompletas de PSTVd está correlacionada con la producción de siRNAs, mientras que no se detectan síntomas ni se acumulan siRNAs en plantas transgénicas que expresan una construcción control con repeticiones directas (Wang et al., 2004). Además, se ha descrito recientemente que plantas de Nicotiana benthamiana con actividad RDR6 silenciada no eran capaces de desarrollar síntomas de infección viroidal a pesar de acumular formas maduras viroidales de HSVd en gran cantidad, pero no vd-sRNAs (Gomez et al., 2008). Sin embargo, no se observó relación entre patogénesis y actividad de RDR6 en plantas de $N$. benthamiana infectadas con una variante particular de PSTVd (Di Serio et al., 2010). La observación de que los niveles de acumulación de vd-sRNAs inducidos por cepas sintomáticas y asintomáticas de PSTVd y CChMVd son similares (Papaefthimiou et al., 2001; Martinez de Alba et al., 2002) sumada a que durante la infección por CEVd no se detectan alteraciones en un reducido grupo de miRNAs de tomate (Martin et al., 2007) constituyen evidencias circunstanciales opuestas a la vinculación de los vd-sRNAs con la patogénesis. 


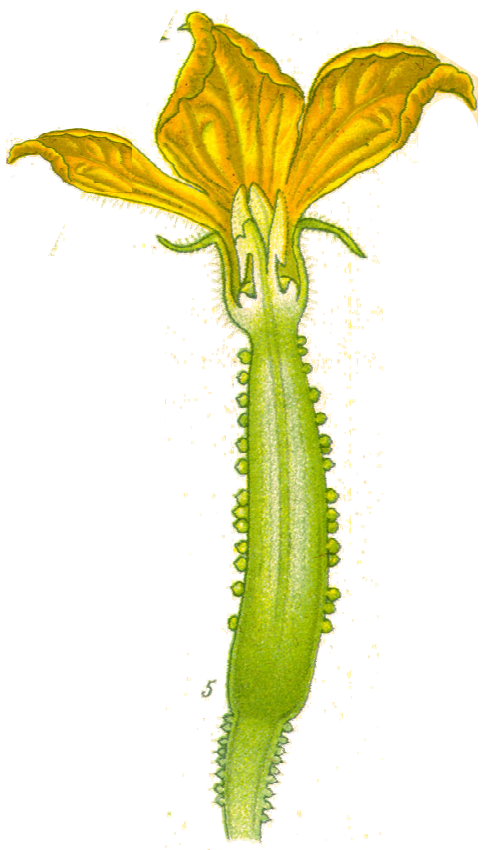

Justificación y Objetivos 
Los viroides son patógenos exclusivos de plantas ubicados en el peldaño basal de la complejidad biológica. Su genoma está compuesto por un RNA de entre 200-400 nts (10 veces menor que el virus de RNA más pequeño) que carece de capacidad demostrada de codificar proteínas. En consecuencia, son estrictamente dependientes de interacciones con factores de la planta para completar su ciclo "vital". Sus huéspedes comprenden una restringida gama de especies de importancia agrícola tanto monocotiledóneas como dicotiledóneas, por lo que su impacto económico es potencialmente alto aunque difícilmente cuantificable.

Pese a todo lo avanzado en su conocimiento, el proceso por el cual estos RNAs de pequeño tamaño interfieren con la maquinaria celular para inducir la expresión de síntomas en la planta infectada es desconocido. Históricamente la interacción entre el RNA genómico del viroide con un factor celular (un RNA o una proteína) ha sido la interpretación más plausible para explicar sus efectos patogénicos. No obstante, esta interpretación es incapaz de resolver cuestiones tales como la falta de correlación entre titulo de viroide y la gravedad de síntomas y aún mas importante tras muchos años de investigación, no se ha descrito ningún factor del huésped que interaccionando con el viroide pueda ser responsable de las alteraciones inducidas durante la infección. Ante la incapacidad de este tipo de interpretaciones de explicar de manera global los mecanismos de patogénesis inducida por viroides, ha emergido en los últimos años una corriente de opinión (basada en un numero cada vez mayor de evidencias experimentales) que postula que posiblemente el silenciamiento de RNA desempeñe un importante papel en la patogénesis y la evolución viroidal.

Al igual que ocurre con los virus de plantas, se ha demostrado que los viroides activan la maquinaría de silenciamiento del huésped, puesto que plantas infectadas acumulan pequeños RNAs derivados del genoma viroidal (vd-sRNAS). Estos vdsRNAs presentan el tamaño típico de los pequeños RNAs originados por Dicer-like (DCL) (entre 20 y 24 nts), y además tienen un grupo fosfato en su extremo 5' y están metilados en su extremo 3'. No obstante, se desconoce con exactitud cuales son los componentes específicos de la maquinaria de silenciamiento responsables de su biogénesis y cual es la molécula precursora de estos sRNAs.

Las formas maduras del los viroides son moléculas circulares con una compleja estructura secundaria, pudiendo por lo tanto comportarse como RNAs de doble cadena (dsRNAs) potenciales sustratos de DCL. No obstante, podrían también serlo sus formas replicativas o la amplificación de estas por la acción de RNA polimerasas dependiente 
de RNA (RDRs) celulares. Conocer estos factores implicados en la biogénesis de los vd-sRNAs pasa necesariamente por llevar a cabo ensayos de clonación y secuenciación de sRNAs. Los primeros ensayos de este tipo a baja escala, han permitido obtener datos confusos y contradictorios sobre el proceso de biogénesis de los vd-sRNAs.

El viroide del enanismo del lúpulo (HSVd) es un viroide nuclear miembro de la familia Pospiviroidae con un genoma de entre 297 y 303 nucleótidos. Este patógeno ha sido descrito en una amplia gama de especies vegetales como lúpulo, pepino, vid, cítricos, melocotonero, peral, ciruelo, almendro, granado y albaricoquero. En algunos de estos huéspedes su infección parece estar latente (vid, albaricoquero), mientras que en otros casos induce desórdenes específicos como enanismo (lúpulo, pepino), manchado del fruto (ciruelo y melocotonero) y cachexia (cítricos).

El objetivo global del presente trabajo de tesis doctoral ha sido llevar a cabo un estudio pormenorizado de las interacciones existentes entre el fenómeno de silenciamiento de RNA y el proceso infeccioso de HSVd en el huésped natural (Cucumis sativus) y en el sistema modelo (Nicotiana benthamiana) con la idea fundamental de determinar si este mecanismo regulador de la expresión génica está implicado en el proceso de patogénesis inducido por los viroides en la planta huésped.

Para ello se plantearon los siguientes subobjetivos:

1- Analizar las alteraciones fenotípicas (síntomas) inducidas por el RNA genómico de HSVd expresado a partir de un transgen en el modelo $N$. benthamianaHSVd.

2- Estudiar las relaciones existentes entre el proceso de patogénesis inducido por HSVd y la maquinaria de silenciamiento de RNA en plantas de $N$. benthamiana.

3- Caracterizar mediante técnicas de secuenciación masiva los pequeños RNAs derivados de HSVd (vd-sRNAs) producidos durante un proceso de infección en un huésped natural (Cucumis sativus).

4- Analizar la distribución diferencial de vd-sRNAs en distintos tejidos (hoja y floema) de plantas de pepino infectadas con HSVd.

5- Determinar las alteraciones inducidas por la infección de un miembro de la familia Pospiviroidae en las vías endógenas de silenciamiento de RNA de la planta huésped, empleando el modelo pepino-HSVd. 


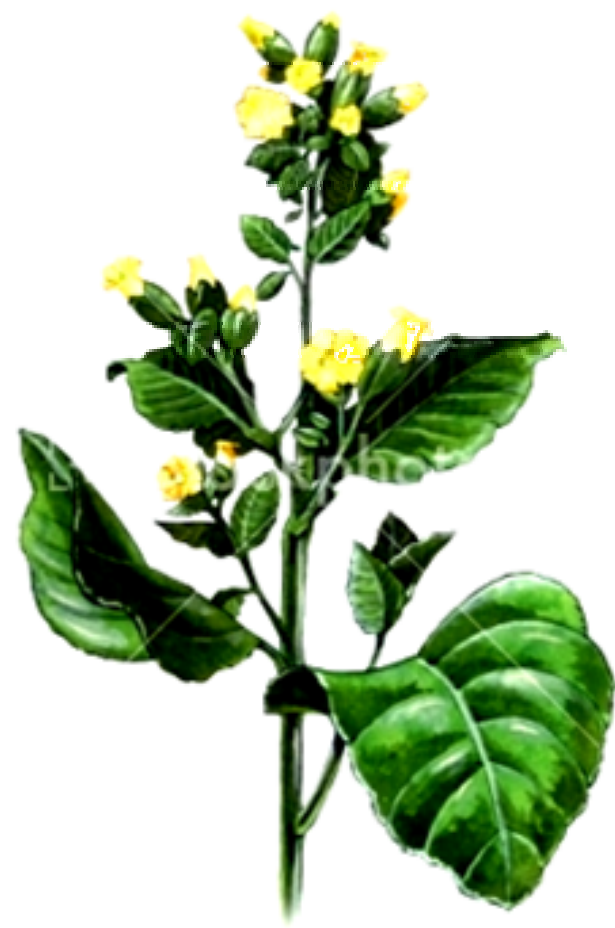

Capítulos 
Capítulo I 


\section{Analysis of symptoms developed in Nicotiana benthamiana plants}

expressing dimeric forms of Hop stunt viroid.

G.Martínez, V.Pallás and G.Gómez

Instituto de Biología Molecular y Celular de Plantas (IBMCP). UPV-CSIC, Avda. de los Naranjos, s/n, 46022, Valencia, Spain.

Journal of Plant Pathology 90 (1), 121-124 (2008). 
The intimate host-pathogen interactions can result in pathogenesis, depending on the host species, pathogen variants and environmental conditions. When this interrelation is referred to viroids, a group of "sui generis" sub-viral agent, the interdependence with the host factors reaches its maximum level. Viroids are plant pathogens whose genomes are composed of a small (250-400 nt) single-stranded circular RNA molecule that do not have protein coding capacity but are able to replicate in susceptible host plants (Ding \& Itaya, 2007; Flores et al. 2005; Tabler \& Tsagris, 2004). Viroid species are classified into two families, Pospiviroidae and Avsunviroidae (Flores et al. 1998). Viroids in the family Pospiviroidae contain a central conserved region $(\mathrm{CCR})$ in their RNA molecule and replication takes place in the nucleus. On the other hand, members of the family Avsunviroidae lack CCR, replicate in the chloroplast and are able to self-cleave through hammerhead ribozymes (Flores \& Pallás, 2006). Given that, viroids have no ability to encode any pathogen-specific proteins, their propagation and associated pathogenesis processes are fully dependent on the host biochemical machinery. This interaction would activate a sequence of poorly understood events that are expressed as visible symptoms (Flores et al. 2005). How these pathogenic RNAs interact with cellular factors to modify host development and physiology is an essential question about the viroid-induced pathogenesis. The most typical symptoms induced by these pathogenic RNAs are associated to deterioration in the growing (stunting) and the flowering (Sano, 2003), usually characterized by shortening of internodes length, reduced flower and leaf size and fruit alterations (Amari et al. 2001; Diener et al. 1988; Sano et al. 1989; Semancik et al. 1988; Shikata et al. 1990).

The Hop stunt viroid (HSVd) is a typical Pospiviroidae, with CCR and without hammerhead self-cleavage that belongs to the genus Hostuviroid. Variants of HSVd have been identified in several crops in which they may cause diseases or replicate as latent infections (Amari et al. 2007, Astruc et al. 1996; Kofalvi et al. 1997; Shikata, 1990). However, attempts to transmit by conventional inoculation $\mathrm{HSVd}$ to $N$. benthamiana, one of the most common model plants to study plant-pathogens interactions, have failed. Recently we have reported that $N$. benthamiana possess the machinery for processing HSVd and the cellular factors required for its long distance translocation, emerging as an important instrument to perform plant-viroid interaction studies (Gómez \& Pallás, 2006). In addition, it was described that the presence of biological forms of HSVd could be associated to development alterations. 
In the present work we have characterized the pathogenesis effects associated to the presence of HSVd in $N$. benthamiana plants, specifically the growing and flowering alterations since these characters represent the most frequent disorders produced by HSVd in naturally infected plants.

To address this question we used transgenic $N$. benthamiana plants expressing a dimeric form of HSVd $(H S V d-N b)$ that have the capability to cleave and circularize the viroid RNA (Gomez \& Pallas, 2006). Two lines of $H S V d-N b$ plants (lines 6 and 8) were first germinated and maintained for 4 weeks in climate chambers at $20^{\circ} \mathrm{C}$ and later on moved to a glasshouse at $28^{\circ} \mathrm{C}$ under standard humid conditions with supplementary illumination to maintain a 16-h daylight period (hereafter all data will be referred to the incubation at $28^{\circ} \mathrm{C}$ ). These are the optimal conditions for the expression of HSVdinduced symptoms in natural hosts. Twelve $H S V d-N b$ plants accumulating similar level of monomeric circular and linear HSVd-forms were used in each experiment with three different repetitions. The different physiological parameters were measured at 4, 8, 12 , 16,20 and 25 days after incubation at $28^{\circ} \mathrm{C}$.

The $H S V d-N b$ plants showed visible symptoms at 8 days after incubation at $28^{\circ} \mathrm{C}$. A moderate stunting was observed in the $H S V d-N b$ plants compared with the untransformed $N$. benthamiana plants (Figure 1A). The stunting was more pronounced at later stages of the incubation (compare days 6 and 23 in Figure 1A) and correlated to a short length of the stem internodes. Although the stunting was more evident in the $H S V d-N b$ line 6 , both transgenic lines showed a marked stunting representing the $72 \%$ of the untransformed plant height at 25 days (Figure 1A and B). Nicotiana benthamiana plants transformed with empty vector and used as controls to discard transgene effects showed normal development (data no shown).

Another characteristic symptom related to HSVd infection is the alteration of the flowering processes that triggers deficiencies in the fruit quality and seeds viability (Singh et al. 2003). To determine if the HSVd induces similar symptoms in $N$. benthamiana, we analyzed different aspects of the flowering process as the appearance of the first flower or the number of flowers/fruits per plant (Figure 2). The flowering of transgenic plants was delayed 7 days in comparison to the control plants, independently of the transgenic line analyzed (Figure 2A). The analysis of the amount of flowers and fruits revealed a negative effect of the presence of HSVd-RNA. The total amount of flowers at 10, 17 and 24 days after the initiation of the flowering corresponded 
respectively to $12 \%, 21 \%$ and $45 \%$ of the control plants (Figure $2 \mathrm{~A}$ ), indicating no only a delay in the flowering but also a significant reduction of the flower quantity.

A

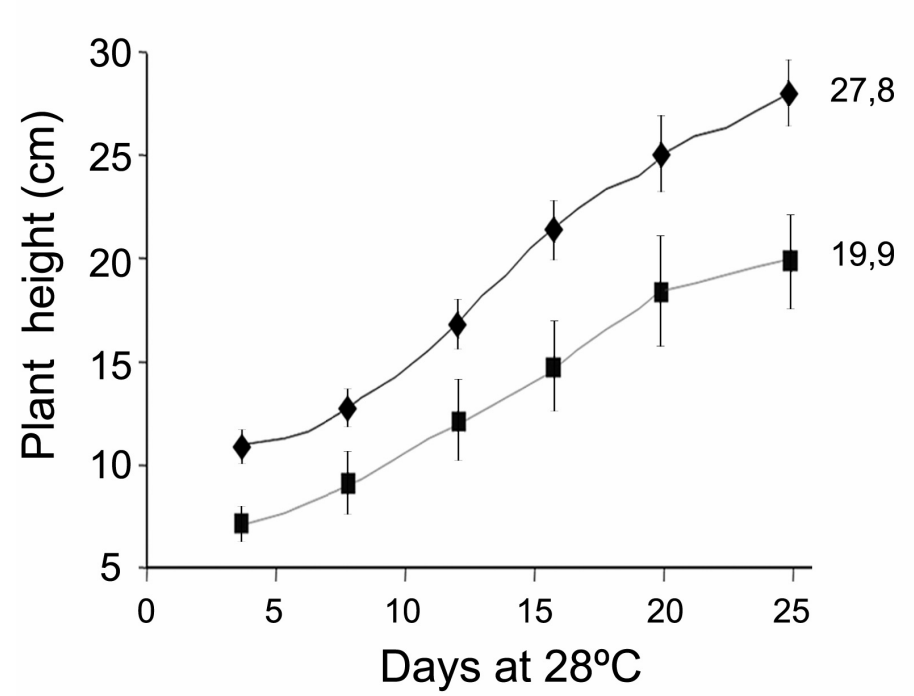

B

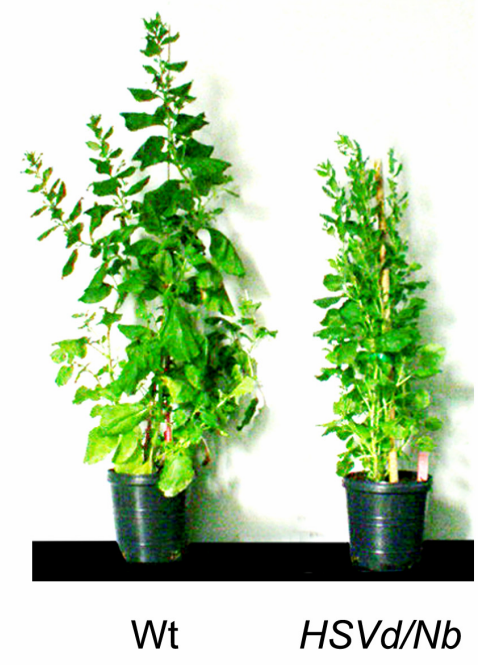

Figure 1: Influence of HSVd on the dynamics of $N$. benthamiana growth.

A) Effects of HSVd biological forms on the development of two lines of transgenic $N$. benthamiana plants $H S V d / N b-6$ (匹) and $\mathrm{HSVd} / \mathrm{Nb}-8(\boldsymbol{\Delta})$. Plant height was measured at 4, 8, 12, 16, 20 and 25 days after incubation at $28{ }^{\circ} \mathrm{C}$. Untransformed $N$. benthamiana $(\downarrow)$ used as growing control. At 23 days, the plant size of $H S V d-N b$ plants corresponded to $72 \%(19.9 \mathrm{~cm})$ of the untransformed plants $(27.8 \mathrm{~cm})$. B) General symptoms induced by HSVd in a representative transgenic $N$. benthamiana plant compared with an untransformed control at 30 days.

A

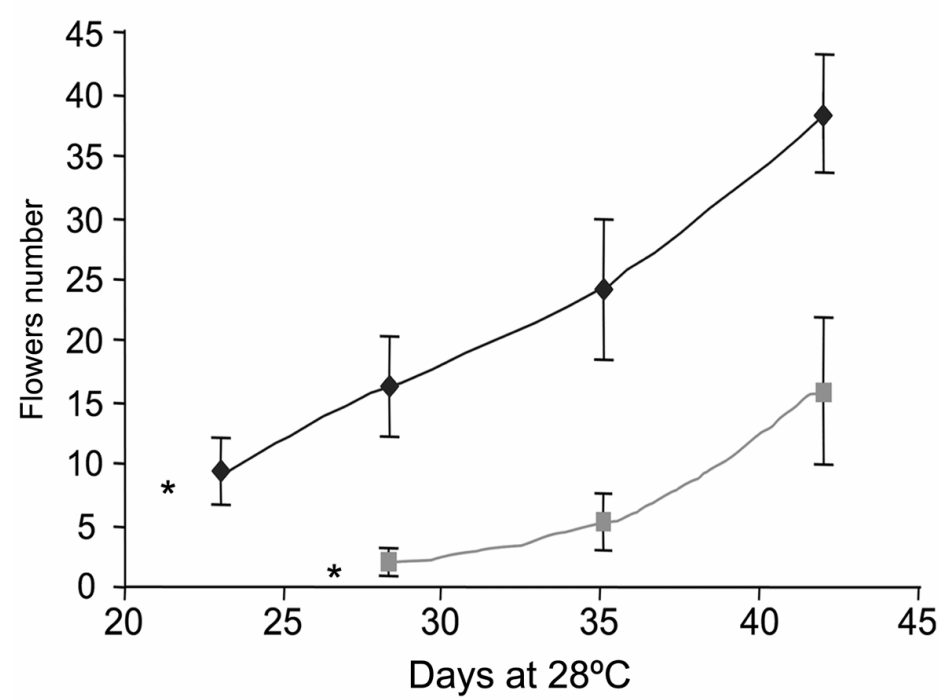

B

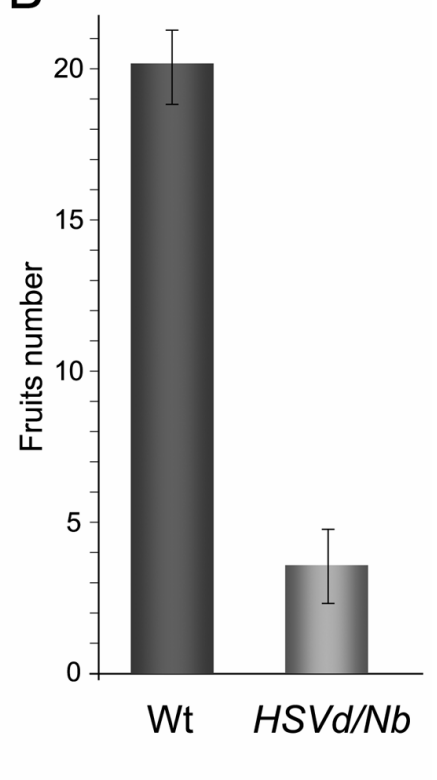

Figure 2: Analysis of flowering process in $H S V d / \mathrm{Nb}$ plants.

A) The flowers number of two lines of $H S V d / N b$ plants ( $)$ and untransformed controls ( $)$ was counted at 3, 10, 17 and 24 days after flowering commence (*) in control plants. In $H S V d / N b$ plants, the flowering beginning was delayed 7 days compared with untransformed $N$. benthamiana. B) The fruits number was determined after 60 days at $28^{\circ} \mathrm{C}$. The amount of fruit in $\mathrm{HSVd} / \mathrm{Nb}$ plants was $16 \%$ of the untransformed controls. 
A reduction of the flower size is another morphological character observed in HSVd natural infections in hop (Sano, 2003) or cucumber plants (Van Dorst \& Peters, 1974). The flower length of each $H S V d-N b$ transgenic lines was measured at the beginning of ripening process after 60 days at $28^{\circ} \mathrm{C}$. Sixty flowers of each transgenic line and untransformed $N$. benthamiana control were analyzed in this assay. The flowers of the $H S V d-N b$ plants were characterized by reduced petal and fruits size (Figure 3A) that represented $81 \%$ of the untransformed control (Figure 3B), resembling the observed in HSVd natural infections. Furthermore, the development of the $\approx 50 \%$ of affected flowers aborted before the ripening, resulting in a severe decrease of the fruit number (Figure 2B). As consequence of flowering and fruit alterations the seeds production was reduced in number and quality (data no shown). This decrease of fertility in $H S V d-N b$ plants was previously reported (Gómez \& Pallás, 2006).
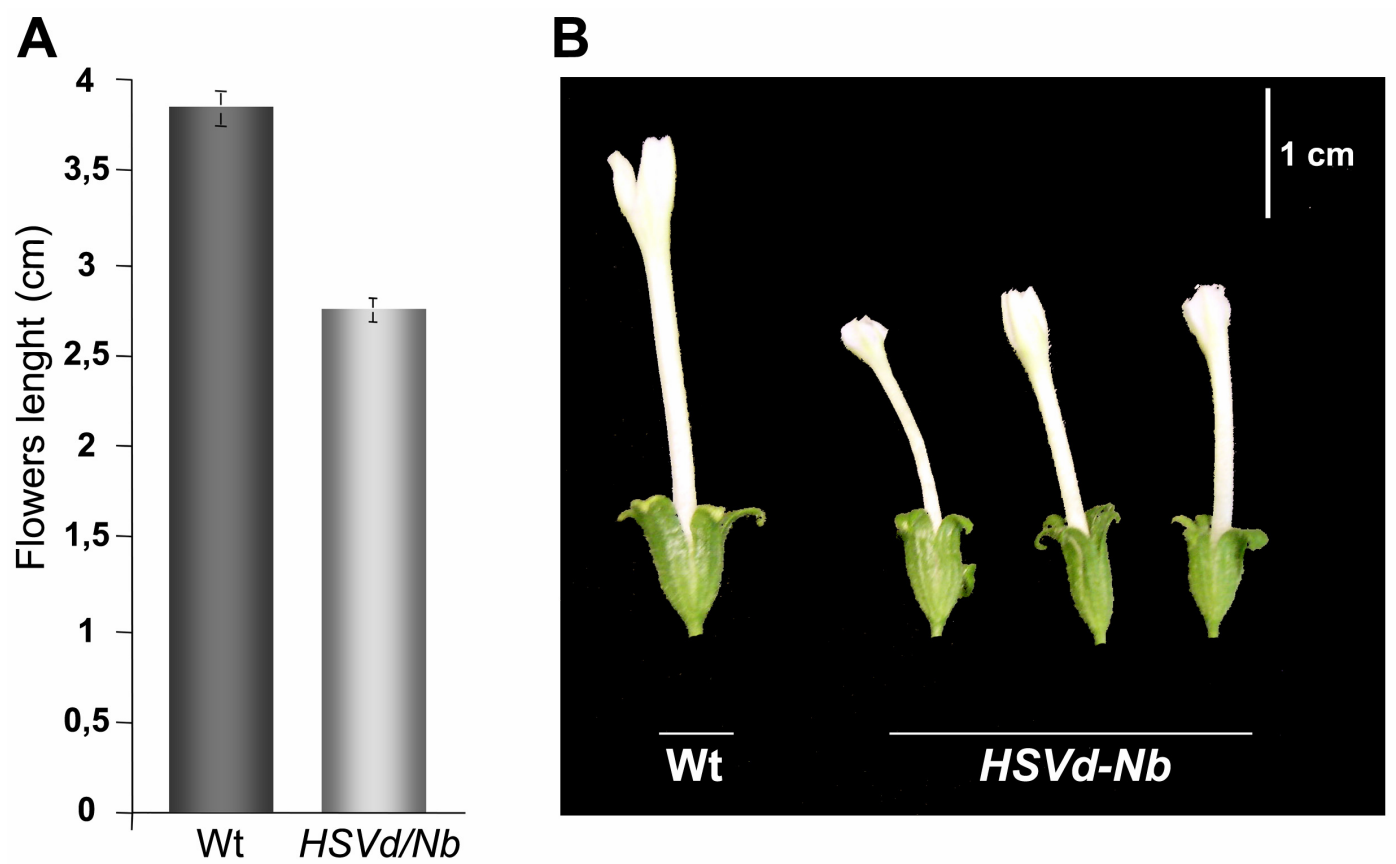

Figure 3: Effects of HSVd on the flower development in N. benthamiana plants.

A) The flower length of the two lines of $H S V d / N b$ plants was measured at the beginning of ripening process after 60 days at $28^{\circ} \mathrm{C}$, and compared with flowers of untransformed $N$. benthamiana plants. The $H S V d / \mathrm{Nb}$ flowers represented approximately the $80 \%$ of the control plants. B) General aspect of representative symptomatic flowers of $H S V d / N b$ plants compared with a control flower.

The obtained results indicate that the accumulation of HSVd mature forms (circular and linear) in transgenic $N$. benthamiana correlate with a "pathogenic" process characterized by stunting and a slight decrease in leaves size. This growing disorder is followed by the strong alteration of flower development and reduced fertility. The 
symptoms observed in $\mathrm{HSVd}-\mathrm{Nb}$ plants are coincident with the most common disorders induced by HSVd in their natural hosts (Diener et al. 1988; Sano et al. 1989; Semancik et al. 1988; Shikata et al. 1990). Apparently, the pathogenic processes associated to the accumulation of biological forms of HSVd in transgenic $N$. benthamiana mimic the disorders in unidentified metabolic pathways induced by conventional HSVd infection.

Although the mechanism of viroid-induced pathogenesis has not been clarified yet, different hypotheses have been proposed to explain this situation. The more attractive idea involves the specific host-mRNA degradation mediated by viroidinduced RNA silencing (Wang et al. 2004). This hypothesis has been reinforced by recent works demonstrating the ability of two members of the Pospiviroidae family, Potato spindle tuber viroid (PSTVd) and HSVd, to simultaneously elicit and resist this plant defense mechanism in tomato (Itaya et al. 2007) and N. benthamiana (Gómez \& Pallás, 2007) plants. In addition, the $H S V d-N b$ lines analyzed herein accumulated HSVd-specific siRNAs (Gómez \& Pallás, 2007). In any case, the model HSVd-N. benthamiana will be an attractive system where both RNA silencing and HSVd induced pathogenesis processes take place, providing a valuable tool to study the specific hostviroid interactions involved in the pathogenesis physiology.

\section{ACKNOWLEDGMENTS}

We thank Dr. J.A. Sanchez-Navarro for their valuable contribution in the critical reading of the manuscript. This work was supported by grant BIO2005-07331 from the Spanish granting agency DGICYT and by grant GV05-238 from the Generalitat Valenciana. G. Martinez is the recipient of a doctoral fellowship granted by MEC and G. Gomez of a contract from the CSIC. 


\section{REFERENCES}

Amari, K., Gómez, G., Myrta, A., Di Terlizzi, B., \& Pallás, V. (2001). The molecular characterization of 16 new sequence variants of Hop stunt viroid reveals the existence of invariable regions and a conserved hammerhead-like structure on the viroid molecule. Journal of General Virology, 82, 953-962.

Amari, K., Ruiz, D., Gómez, G., Sánchez-Pina, M.A., Pallás, V., \& Egea, J. (2007). An important new apricot disease in Spain is associated with Hop stunt viroid infection. European Journal of Plant Pathology, 118, 173-181.

Astruc, N., Marcos, J., Macquaire, G., Candresse, T., \& Pallás, V. (1996). Studies on the diagnosis of hop stunt viroid in fruit trees: Identification of new hosts and application of a nucleic acid extraction procedure based on non-organic solvents. European Journal of Plant Pathology, 102, 837-846.

Diener, T., Smith, D., Hammond, R., Albanese, G., La Rosa, R., \& Davino, M. (1988). Citrus B viroid identified as a strain of hop stunt viroid. Plant Disease, 72, 691-693.

Ding, B. \& Itaya, A. (2007). Viroid: A useful model for studying the basic principles of infection and RNA biology. Molecular Plant-Microbe Interactions, 20, 7-20.

Flores, R., Randles, J.W., Bar-Joseph, M., \& Diener, T. (1998). A proposed scheme for viroid classification and nomenclature. Archives of Virology, 143, 623-629.

Flores, R., Hernández, C., Martínez de Alba, A., Daròs, J.A., \& Di Serio, F. (2005). Viroids and viroid host interactions. Annual Review of Phytopathology, 43, 117-139.

Flores, R. \& Pallás, V. (2006). Viroids. (In Khan, J. A. and Dijkstra, J., eds, Handbook of Plant Virology). New York: The Haworth Press, Inc. pp, 93-104.

Gómez, G. \& Pallás, V. (2004). A long-distance translocatable phloem protein from cucumber forms a ribonucleoprotein complex in vivo with Hop stunt viroid RNA. Journal of Virology, 78, 10104-10110.

Gómez, G. \& Pallás, V. (2006). Hop stunt viroid is processed and translocated in transgenic Nicotiana benthamiana plants. Molecular Plant Pathology, 7, 511-517.

Gómez, G. \& Pallás, V. (2007). Mature monomeric forms of Hop stunt viroid resist RNA silencing in transgenic plants. The Plant Journal, In press.

Itaya, A., Zhong, X., Bundschuh, R., Qi, Y., Wang, Y., Takeda, R., Harris, A.R., Molina, C., Nelson, R.S., \& Ding, B. (2007). A structured viroid RNA Is substrate for DicerLike cleavage to produce biologically active small RNAs but is resistant to RISCmediated degradation. Journal of Virology, 81, 2980-2994.

Kofalvi, S.A., Marcos, J.F., Canizares, M.C., Pallas, V., \& Candresse, T. (1997). Hop stunt viroid (HSVd) sequence variants from Prunus species: evidence for recombination between HSVd isolates. Journal of General Virology, 78, 3177-3186.

Sano, T., Hataya, T., Terai, Y., \& Shikata, E. (1989). Hop stunt viroid strains from dapple fruit disease of plum and peach in Japan. Journal of General Virology, 70, 1311-1319.

Sano, T. (2003). Hop stunt viroid. In: Viroids. A. Hadidi, J. Randles, J. Semancik \& R. Flores (Eds.). pp 207-213. St Paul, USA: Science Publisher. 
Semancik, J., Roistacher, C., Rivera-Bustamante, R., \& Durán-Vila, N. (1988). Citrus cachexia viroid, a new viroid of citrus: Relationship to viroids of the exocortis disease complex. Journal of General Virology, 69, 3059-3068.

Shikata, E. (1990). New viroids from Japan. Seminars in Virology, 1, 107-115.

Singh, R.P., Ready, K.F., \& Nie, X. (2003). Biology. In: Viroids. A. Hadidi, J. Randles, J. Semancik \& R. Flores (Eds.). pp 30-48. St Paul, USA: Science Publisher

Tabler, M. \& Tsagris, M. (2004). Viroids: petite RNA pathogens with distinguished talents. Trends in Plant Science, 9, 339-348.

Van Dorst, H.H \& Peters, D. (1974). Some biological observations on pale-fruit viroidincited disease of cucumber. Netherlands Journal of Plant Pathology, 80, 85-96.

Wang, M.B., Bian, X.Y., Wu, L.M., Liu, L.X., Smith, N.A., Isenegger, D., Wu, R. M., Masuta, C., Vance, V.B., Watson, J.M., Rezaian, A., Dennis, E.S., \& Waterhouse, P.M. (2004). On the role of RNA silencing in the pathogenicity and evolution of viroids and viral satellites. Proceedings of the National Academy of Sciences, USA. 101, 275-3280. 
Capitulo II 


\title{
Viroid-induced symptoms in Nicotiana benthamiana plants are dependent on RDR6 activity
}

Gustavo Gómez, Germán Martínez and Vicente Pallás

Instituto de Biología Molecular y Celular de Plantas (IBMCP). UPV-CSIC, Avda. de los Naranjos, s/n, 46022, Valencia, Spain.

Plant Physiology 148, 414-423 (2008)

\begin{abstract}
Viroids are small self-replicating RNAs that infect plants. How these noncoding pathogenic RNAs interact with hosts to induce disease symptoms is a long-standing unanswered question. Recent experimental data have led to the suggestive proposal of a pathogenic model based on the RNA silencing mechanism. However, evidence of a direct relation between key components of the RNA silencing pathway and symptom expression in infected plants remains elusive. To address this issue, we used a symptomatic transgenic line of Nicotiana benthamiana that expresses and processes dimeric forms of Hop stunt viroid (HSVd). These plants were analyzed under different growing temperature conditions and were used as stocks in grafting assays with the rdr6i-Nb line, in which the RNA-dependent RNA polymerase 6 (RDR6) is constitutively silenced. Here, we show that the symptom expression in $\mathbf{N}$. benthamiana plants is independent of HSVd accumulation levels but dependent on an active state of the viroid-specific RNA silencing pathway. The scion of rdr6i-Nb plants remained asymptomatic when grafted onto symptomatic plants, despite an accumulation of a high level of mature forms of HSVd, indicating the requirement of RDR6 for viroid-induced symptom production. In addition, the RDR6 requirement for symptom expression was also observed in wild-type $\mathrm{N}$. benthamiana plants mechanically infected with HSVd. These results provide biological evidence of the involvement of the viroid-specific RNA silencing pathway in the symptom expression associated with viroid pathogenesis.
\end{abstract}




\section{INTRODUCTION}

One of the most intriguing and still unsolved topics in the study of pathogenhost interactions is how these agents, in their way to suppress host defense, cause undesirable pathological effects. Pathogens recruit host routes/factors to self-perpetuate within the invaded cell and to translocate to neighbouring groups of cells. Plant viruses have the potential to use from 5 to 30 viral origin proteins to accomplish these functions whereas viroids, the smallest known infectious agents in plants, must take advantage of their structurally informative circular RNA molecule to do so (Hull, 2002; Tabler and Tsagris, 2004; Daròs et al., 2006; Ding and Itaya, 2007). In view of the recent picture emerging with the non-coding RNAs as key components of the regulation mechanisms of developmental and defense processes, viroids have become one of the most productive tools to unravel some of the fundamental principles of life processes (Ding and Itaya, 2007).

Viroid genomes consist of a single-stranded, covalently closed circular, noncoding, and non- encapsidated RNA, ranging from 246 to 401 nucleotides long (Tabler and Tsagris, 2004; Flores et al., 2005; Flores and Pallás, 2006; Daròs et al., 2006; Ding and Itaya, 2007). The search of plant-cell components involved in the regulation of biological processes of viroid diseases has allowed to identify different host factors involved in viroid replication (Daròs and Flores, 2002) and movement (Owens et al., 2001; Gómez and Pallás, 2001 and 2004; Gómez et al., 2005). Despite intensive research however, the basic question as to how these pathogenic RNAs alter, when they do, the host development and physiology to induce disease symptoms remains unanswered.

It has long been accepted that the genomic RNA acts as the primary pathogenic effector via a direct interaction between specific viroid motifs and cellular factors (Diener, 1999; Flores et al., 2004 and 2005). However, the identification of a group of small RNAs that regulate the host and non-host gene expression in eukaryotes has led to a new hypothesis based on the viroid pathogenesis possibly being mediated by the interference of specific host-mRNA expression via viroid-induced RNA silencing (Papaefthimiou et al., 2001; Conejero, 2003; Markarian et al., 2004; Wang et al., 2004).

RNA silencing is a sequence-specific RNA-inactivation mechanism described in diverse eukaryotes that guides gene regulation, chromatin modification and defense against viruses (Baulcombe, 2002; Vogt et al., 2004; Brodersen and Voinnet, 2006; 
Ding and Voinnet, 2007). These different biological processes share three biochemical characteristics: (i) formation of double-stranded RNA (dsRNA); (ii) processing dsRNAs to 20-26 nt small RNAs (sRNAs) and (iii) inhibitory action of sRNAs on complementary RNA or DNA (Brodersen and Voinnet, 2006). The sRNAs, the central molecules of the RNA silencing pathway, are broadly classified into microRNAs (miRNAs) and small interfering RNAs (siRNAs), which have similar chemical structures but differ in their function and mode of biogenesis. Production of both types of sRNAs depends on the activity of RNase III-type enzymes known as Dicer (Llave et al., 2002; Brodersen and Voinnet, 2006; Vaucheret, 2006; Ding and Voinnet, 2007).

In plants, a RNA-dependent RNA polymerase (RdRp), initially identified as RDR6, was shown to be essential for post transcripcional gene silencing (PTGS) induced by sense transgene (S-PTGS) and by some viruses (VIGS), but not required for inverted repeat dsRNA-induced PTGS (IR-PTGS) (Dalmay et al., 2000, Mourrain et al., 2000; Vance and Vaucheret, 2001). RDR6 is also involved in the transitivity phenomenon (Vaistij et al., 2002). Transitivity can be explained as the transition of primary siRNAs to secondary siRNAs that serves as an amplification mechanism of the initial RNA-silencing reaction (Brodersen and Voinnet, 2006) and accounts for their systemic spreading (Himber et al., 2003; Schwach et al., 2005). Accumulation of secondary siRNAs during PTGS of exogenous nucleic acids, including many viruses and transgene transcripts, is dependent on RDR6 in A. thaliana plants. In addition, RDR6 is functionally involved in the biogenesis of trans-acting siRNAs (tasiRNAs) (Allen et al., 2004; Peragine et al., 2004, Vazquez et al., 2004) and natural antisense transcript siRNAs (natsiRNAs) (Brodersen and Voinnet, 2006; Chapman and Carrington, 2007). Consequently, diverse small RNA pathways in plants have an RDR6 requirement.

The RNA silencing is also affected by environmental factors, especially temperature. High temperatures are frequently associated with enhanced RNA silencing activity, whereas low temperatures inhibit this regulatory mechanism (Szittya et al., 2003; Qu et al., 2005).

Increasing evidence indicates that viroid genomic RNA and/or their replicative intermediates are inductors and potential targets of RNA silencing (Martinez de Alba et al., 2002; Vogt et al., 2004; Wang et al., 2004; Gómez and Pallás, 2007; Itaya et al., 2007; Martin et al., 2007). Moreover, it has been recently demonstrated that mature forms of Potato spindle tuber viroid (PSTVd) and Hop stunt viroid (HSVd), can 
simultaneously elicit and resist this plant defense mechanism in tomato (Itaya et al., 2007) and Nicotiana benthamiana (Nb) (Gómez and Pallás, 2007) plants, respectively. Interestingly, these results have provided a unified picture in which these non-coding RNAs are inductors, potential targets, and evaders of RNA silencing at the same time (Wang et al., 2004; Ding and Itaya, 2007; Gómez and Pallás, 2007; Itaya et al., 2007).

The possibility that viroid-induced RNA silencing could be associated with the symptom expression in infected plants was originally suggested by Papaefthimiou et al (2001). This idea was reinforced by the observation that the symptoms severity in Gynura aurantiaca plants infected with Citrus exocortis viroid (CEVd) correlated with CEVd-specific siRNAs accumulation but not with the viroid titer (Markarian et al., 2004). Later, Wang et al., (2004) showed that transgenic tomato plants expressing a hairpin construct of a partial length sequence of PSTVd accumulated specific siRNAs and developed symptoms similar to those of PSTVd infection. Authors suggested that RNA silencing plays an important role in the pathogenesis and evolution of these subviral RNAs. Based on these findings, they proposed that the viroid-specific siRNAs might function like miRNAs to down-regulate the expression of physiologically important host genes and induce disease-associated symptoms by means of RNA silencing pathway (Wang et al., 2004). In addition, there have been recent reports showing that high levels of PSTVd-specific siRNAs were associated with the expression of strong symptoms in $\mathrm{Nb}$ plants after biolistic infection (Matoušek et al., 2007). Even though the involvement of viroid-specific RNA silencing is currently accepted as a plausible explanation for viroid-induced pathogenesis (Tabler and Tsagris, 2004; Ding and Itaya, 2007), biological evidences of a direct correlation between the viroid-specific RNA silencing pathway and symptom expression are scarce.

We reasoned that if the symptoms developed by a viroid infection are mediated by RNA silencing, then the following predictions should be fulfilled: $i$ ) the inhibition of the RNA silencing activity would be associated with the decrease in the symptoms severity and ii) infected plants with deficiencies in the RNA silencing pathway would either be asymptomatic or show a reduction in the severity of symptoms. In an attempt to validate these predictions, we used a symptomatic transgenic line of $N$. benthamiana $(H S V d-N b)$ expressing and processing a dimeric HSVd-RNA into the biologically active monomeric circular and linear forms (Gómez and Pallás, 2006). In these plants, the mature forms of the HSVd could resist the HSVd-induced RNA silencing-mediated degradation; whereas the identical full-length HSVd sequences fused to the mRNA 
GFP could not. Consequently, the HSVd-GFP construct could be used as a reporter of the HSVd-specific RNA silencing activity (Gómez and Pallás, 2007). The HSVd-Nb plants were analyzed under different growth temperature conditions and used as stocks in grafting assays with the $r d r 6 i-N b$ line, in which the Nb-RDR6 is constitutively silenced (Schwach et al., 2005). In addition, HSVd-agroinoculation assays were performed in $\mathrm{Wt}-\mathrm{Nb}$ and $r d r 6 i-\mathrm{Nb}$ plants, to analyze the interrelation between RNA silencing and pathogenesis in a conventional infection. The findings presented in this paper demonstrate that, in $N b$ plants, the symptoms induced by viroid infection are dependent on RDR6 activity, a key component of diverse RNA silencing pathways, and their severity is associated with efficient viroid-specific RNA silencing activity.

\section{RESULTS}

\section{The HSVd-symptom expression is dependent on the temperature but independent on the accumulation levels of HSVd mature forms}

Stunting was recently observed as the most characteristic symptom induced by the expression of a dimeric form of HSVd in four independent transgenic lines of HSVd-Nb plants (Gómez and Pallás, 2006; Martinez et al., 2008). Thus, this phenotypic character was selected to determine symptoms intensity. To test whether the HSVdinduced symptoms in $\mathrm{Nb}$ are temperature dependent, $H S V d-N b$ plants were grown at different temperatures $\left(28^{\circ} \mathrm{C}, 20^{\circ} \mathrm{C}\right.$ and $\left.14^{\circ} \mathrm{C}\right)$, and symptoms were evaluated as severe, moderate or null.

Striking differences in symptom expression were observed. As Figure 1A shows, the average height of $H S V d-N b$ plants at $28^{\circ} \mathrm{C}$ was severely reduced, as the plant height of the $W t-N b$ plants at 50 days post-incubation (dpi) was only 60\% (Figure 1B). Stunting was moderate in the $H S V d-N b$ plants incubated at $20^{\circ} \mathrm{C}$ (Figure 1A), representing $80 \%$ of the height of controls plants on average (Figure 1B). On the other hand, although the plants which were incubated at $14^{\circ} \mathrm{C}$ presented a slight reduction in growth (11-14\% on average) at 30-35 dpi (Figure 1B), the $H S V d$-induced stunting in relation to controls was absent at 50 dpi (Figure 1A and 1B). These results indicate that, as observed for the naturally infected hosts, the HSVd-induced symptoms in $\mathrm{HSVd}-\mathrm{Nb}$ are temperature dependent being severe at high temperatures and decrease at low temperatures until they eventually disappear. 
To check whether the variation in the symptoms severity observed in the $H S V d$ $\mathrm{Nb}$ plants grown at different temperatures was associated with alterations at the level of accumulation of the viroid, we analyzed the levels of $\mathrm{HSVd}$ in plants incubated at $28^{\circ} \mathrm{C}$, $20^{\circ} \mathrm{C}$ and $14^{\circ} \mathrm{C}$.
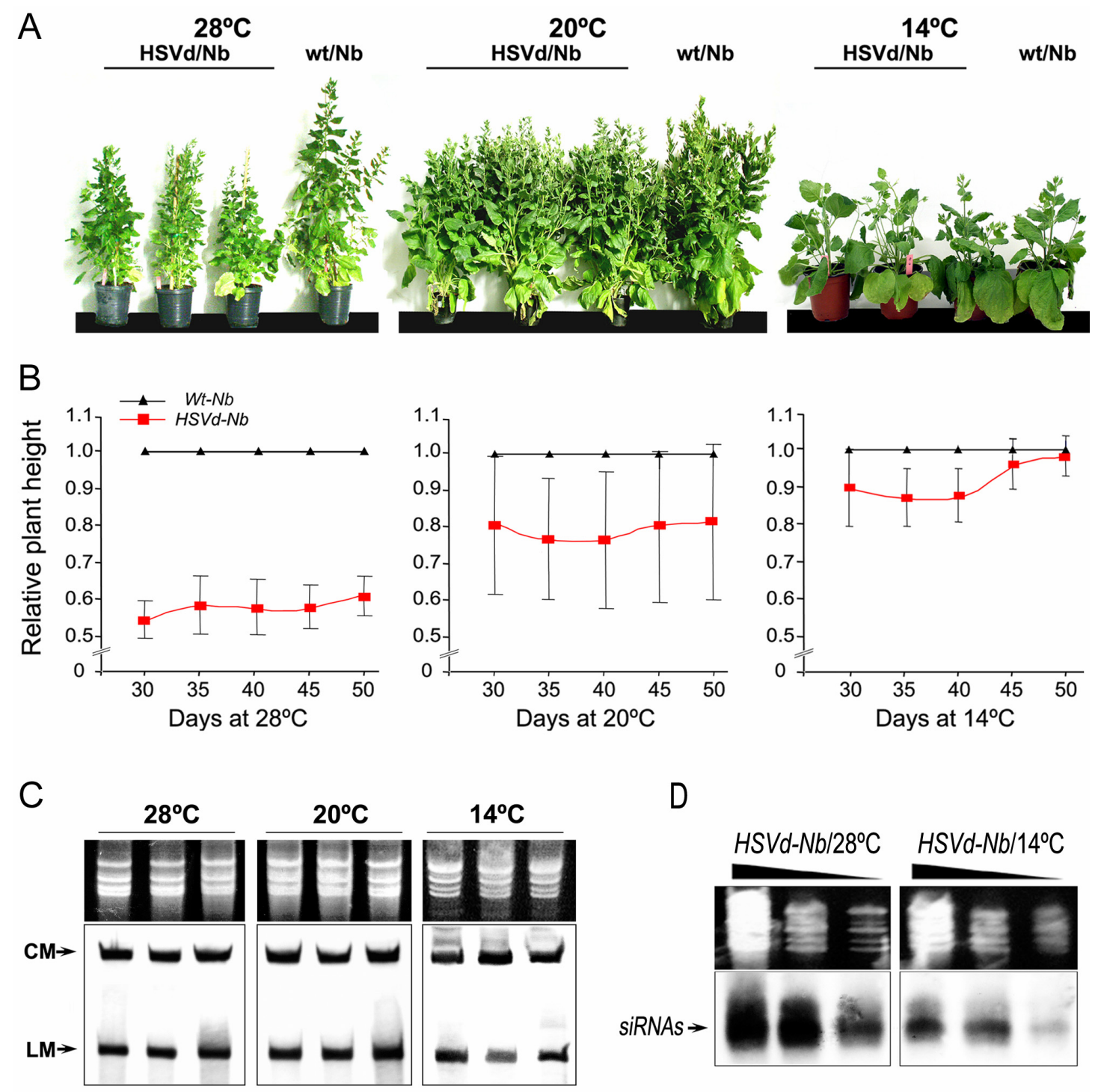

Figure 1. Symptoms induced by HSVd in transgenic $N$. benthamiana plants ( $H S V d-N b)$. (A) $H S V d-N b$ plants grown 50 days at $28^{\circ} \mathrm{C}, 20^{\circ} \mathrm{C}$ and $14^{\circ} \mathrm{C}$, compared with an untransformed control kept under the same growing conditions. (B) Influence of the temperature on the dynamics of $H S V d-N b$ growth. The relative height of ten $H S V d-N b$ plants was measured at $30,35,40,45$ and 50 days after incubation at $28^{\circ} \mathrm{C}, 20^{\circ} \mathrm{C}$ and $14^{\circ} \mathrm{C}$. Bars indicate standard deviations values between the 10 analyzed plants. (C) Northern blot assays of total RNA from 3 different $H S V d-N b$ plants grown at $28^{\circ} \mathrm{C}, 20^{\circ} \mathrm{C}$ and $14^{\circ} \mathrm{C}$. The levels of circular (CM) and linear (LM) monomeric forms of HSVd were kept constant at the different temperatures. (D) Small-RNA enriched RNAs were extracted from three-pooled $H S V d$ $\mathrm{Nb}$ plants maintained at $28^{\circ} \mathrm{C}$ (symptomatic) and $14^{\circ} \mathrm{C}$ (asymptomatic) respectively. The RNAs were diluted $1 / 1,1 / 5$ and $1 / 25$ and analyzed by Northern blot assays to detect HSVd-specific siRNAs. RNAs were quantified by spectrometry and their concentration equalled. $E t B r$ stained gels are shown as RNA load controls (in C and D).

They respectively presented severe, moderate or null stunting. Hybridization assays revealed that HSVd circular and linear monomeric forms accumulated at similar 
levels in $\mathrm{Nb}$ plants at the tested temperatures (Figure 1C), indicating that the differences observed in symptoms intensity in the $H S V d-N b$ incubated at $28^{\circ} \mathrm{C}$, when compared with the plants incubated at $20^{\circ} \mathrm{C}$ and $14^{\circ} \mathrm{C}$, are independent of $\mathrm{HSVd}$ accumulation levels. Interestingly, hybridization assays revealed a reduction of the HSVd-specific siRNAs concentration in the asymptomatic $H S V d-N b$ plants grown at $14^{\circ} \mathrm{C}$ when compared with the symptomatic $H S V d-N b$ plants grown at $28^{\circ} \mathrm{C}$ (Figure 1D), suggesting a possible association between the HSVd-specific siRNAs level and viroidinduced symptoms.

\section{Low temperatures affect the $H S V d$ RNA-induced RNA silencing}

It was previously demonstrated that the defense pathway mediated by RNA silencing was inhibited at low temperatures in diverse plant-virus interactions (Szittya et al., 2003). Therefore, we went on to determine whether the lack of symptoms in the $H S V d-N b$ plants grown at $14^{\circ} \mathrm{C}$ could be associated with alterations in the HSVd RNAinduced RNA silencing pathway.

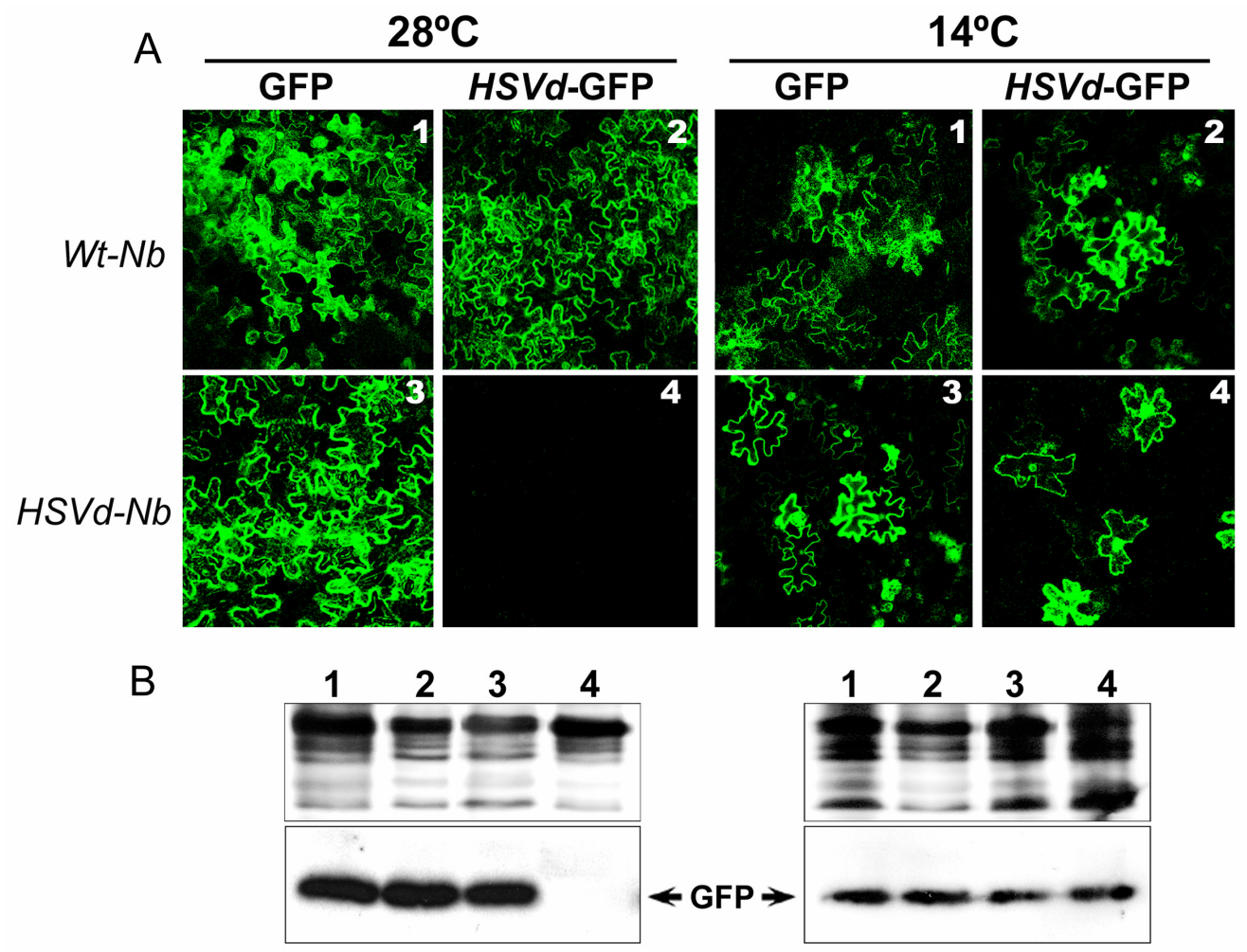

Figure 2. The HSVd-GFP expression is not suppressed in asymptomatic $H S V d-N b$ plants grown at $14^{\circ} \mathrm{C}$. (A) $W t-N b$ and $H S V d-N b$ plants, kept at $28^{\circ} \mathrm{C}$ (left) and $14^{\circ} \mathrm{C}$ (right) were agroinfiltrated with the HSVd-GFP reporter. As observed in (A, panel 4 left), the reporter expression is suppressed in symptomatic $H S V d-N b$ plants incubated at $28^{\circ} \mathrm{C}$. In contrast, when the silencing reporter was infiltrated in the asymptomatic $\mathrm{HSVd}$ - $\mathrm{Nb}$ incubated at $14^{\circ} \mathrm{C}$ (panel 4 right) GFP fluorescence was similar to that observed in the control plants. (B) Detection of HSVd-GFP reporter by Western blot analysis of total proteins extracted from the agroinfiltrated $\mathrm{Wt}-\mathrm{Nb}$ and $H S V d-\mathrm{Nb}$ plants. Silver staining gels are shown as protein load controls. 
To test this possibility, agroinfiltration assays using an HSVd-GFP reporter (Gómez and Pallás, 2007b), were carried out in the $H S V d-N b$ plants incubated at $28^{\circ} \mathrm{C}$ (symptomatic) and $14^{\circ} \mathrm{C}$ (asymptomatic). Consistent with previous results (Gómez and Pallás, 2007), the expression of the HSVd-GFP reporter was suppressed in the HSVd$\mathrm{Nb}$ plants incubated at $28^{\circ} \mathrm{C}$, but not in the $W t-N b$ control plants which indicates an HSVd-specific RNA silencing activity in the symptomatic $H S V d-N b$ plants incubated at $28^{\circ} \mathrm{C}$ (Figure 2A, 2B, left). In contrast, when the reporter was infiltrated in the asymptomatic $H S V d-N b$ plants incubated at $14^{\circ} \mathrm{C}$, the GFP gene was not suppressed and the fluorescence level was similar to that observed in control plants (Figure 2A, 2B, right). These results demonstrate that plants grown under conditions in which RNA silencing is less efficient did not develop any symptoms at all, whereas plants grown under conditions where RNA silencing was active, underwent severe stunting. These results establish a strong correlation between the activity level of the viroid-specific RNA silencing and the symptom expression.

\section{The expression of HSVd-induced symptoms depends on RDR6 activity}

It has been recently demonstrated that the reduced expression of the $N b-R D R 6$ results in hypersusceptibility to some viruses (Schwach et al., 2005). In addition, $\mathrm{Nb}$ RDR6 has been mechanistically implicated in transitive silencing and diverse small RNAS pathways (Brodersen and Voinnet, 2006; Chapman and Carrington, 2007). To investigate whether the symptomatology observed in infected plants is related to the viroid-induced RNA silencing pathway, we examined the symptom development in transgenic rdr6i-Nb grafted onto $\mathrm{HSV}-\mathrm{Nb}$ plants.

We reasoned that if RDR6-dependent RNA silencing pathways mediates the viroid pathogenesis HSVd would infect the silence-defective $r d r 6 i$-scions without developing the characteristic symptoms. Conversely, in the $W t$-scions, the HSVdinfection would develop the characteristic pathogenic effects. To test this prediction, the scion length was monitored and measured at 30 and 45 days after grafting (dag).

$W t$-scions showed moderate stunting at $17 \mathrm{dag}$, whereas $r d r 6 i$-scions did not (Supplemental figure1). Size reduction was more pronounced (44\% of the size of the corresponding rdr6i-scions) at later stages of the incubation, as observed in Figure 3B, that represents the average length of $W t-N b$ and $r d r 6 i-N b$ scions at 30 dag. Severe stunting in the $W t$-scions was observed at $45 \mathrm{dag}$, representing $32 \%$ of the size of the rdr6i-scions on average (Figure $3 \mathrm{~A}$ and $3 \mathrm{~B}$ ). Moreover, the leaves of $W t$-scions 
presented a considerable size reduction and chlorosis followed by necrosis when compared with the normal development of the $r d r 6 i$-scions grafted onto identical stocks (Figure 3A and Supplemental figure 2 and 3). Consistently with previous results (Gómez and Pallás, 2006), the sequence of the HSVd RNA isolated from scion tissue was identical to the HSVd sequence present in the stock (data no shown).

To test whether the presence or absence of symptoms observed in scions was associated with a differential concentration of the viroid, we analyzed the levels of HSVd in symptomatic $W t-N b$ and asymptomatic $r d r 6 i-N b$ scions. Hybridization assays revealed that the HSVd accumulated at similar levels in both scion types (Figure 3C), demonstrating that the viroid-induced symptoms observed in the infected $\mathrm{Wt}-\mathrm{Nb}$ scions are dependent on the RDR6 activity, but not on the HSVd accumulation level. Furthermore, a significant reduction of the siRNAs concentration in the asymptomatic $r d r 6 i$-scions when compared with the symptomatic $W t$-scions was observed (Figure 3D) reinforcing the possible association between the HSVd-specific siRNAs level and viroid-induced symptoms. In order to obtain additional evidence of the relation between HSVd-specific RNA silencing and the symptom expression, we analyzed the accumulation of HSVd-specific siRNAs and HSVd mature forms in the HSVd-Nb (stocks) and $r d r 6 i-N b$ (scions) plants. The difference in siRNAs accumulation was also observed when the rdr6i-scions were compared to $H S V d-N b$ stocks, even though the viroid titer in the two sources was similar (Figure 3E). The observation that the levels of mature forms of HSVd were similar in asymptomatic scion and symptomatic stocks (Figure 3E) indicates that the symptoms observed in infected $\mathrm{Nb}$ plants are also independent of HSVd accumulation levels in the grafts assays. To further discard that HSVd-transgene derived transcripts could influence the observed differences, we performed an alternative experiment using $\mathrm{Wt}-\mathrm{Nb}$ and $r d r 6 i-\mathrm{Nb}$ plants infected by mechanical agro-inoculation of HSVd-RNA, a recently described efficient method to induce PSTVd (Carbonell et al., 2008) and HSVd (Flores et al, personal communication) infection in $\mathrm{Nb}$ plants. Inoculated $\mathrm{Wt}-\mathrm{Nb}$ plants showed moderate stunting at 25 days post inoculation (dpi) compared with no inoculated controls, whereas inoculated $r d r 6 i-N b$ plants did not (data no shown). Size reduction was more significant at 30 and 45 dpi, representing $81 \%$ of the size of the uninoculated controls on average (Figure 4A and Supplemental figure 4). Both, the stunting and leaf reduction size were induced by HSVd in the infected $W t-N b$ plants as well as in the 
$H S V d-N b$ plants, indicating that the symptomatic phenotype described in the HSVd-Nb plants was consequence of a viroid-induced pathogenesis process.

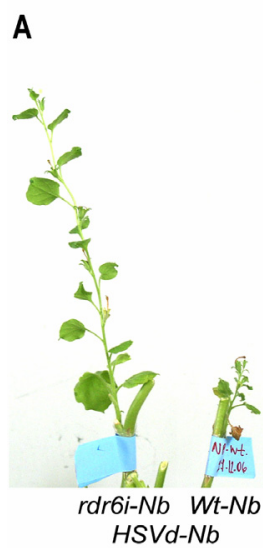

B

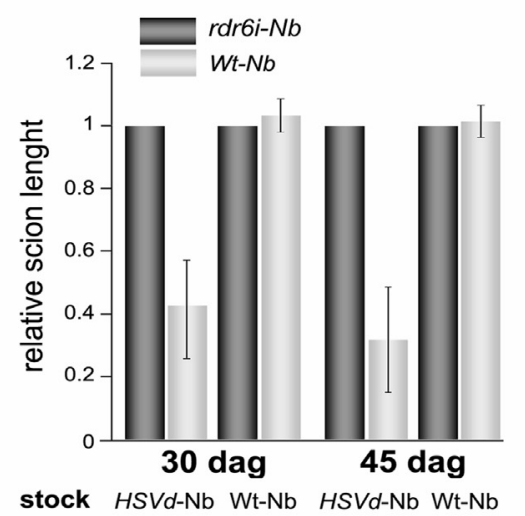

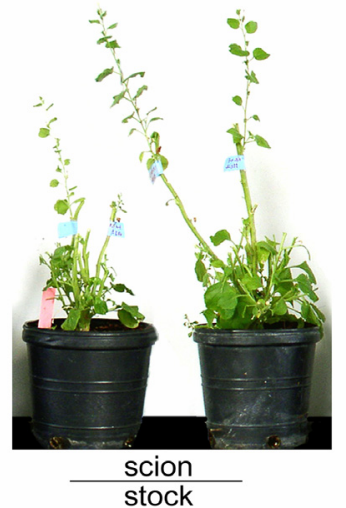

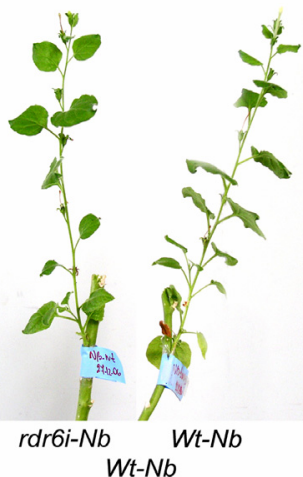

C
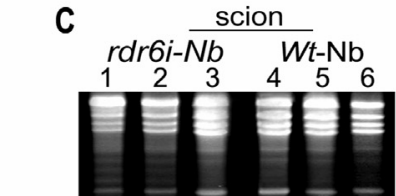

$\mathrm{CM}$

LM
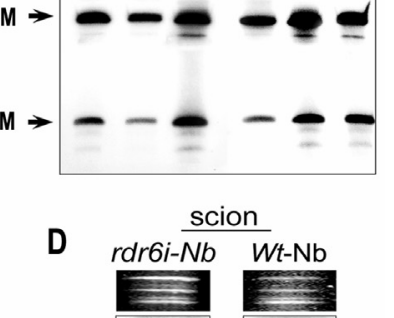

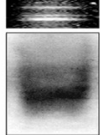

Figure 3. Effects of the HSVd accumulation in $\mathrm{Wt}-\mathrm{Nb}$ and $r d r 6 i$ $\mathrm{Nb}$ plants. Two week-old $\mathrm{Wt}-\mathrm{Nb}$ and $r d r 6 i-N b$ scions were grafted onto symptomatic transgenic $H S V d$ - $N b$ stocks, and kept at $28^{\circ} \mathrm{C}$. (A central panel) General symptoms induced by HSVd in a representative $W t-N b$ scion compared with an $r d r 6 i-N b$ scion grafted onto identical $H S V d-N b$ stock at 45 days after grafting (dag). The left and right panels show a magnified image of the grafts. (B) Relative length of $W t$ $\mathrm{Nb}$ and $r d r 6 i-N b$ scions grafted onto $\mathrm{Wt}-\mathrm{Nb}$ and $\mathrm{HSVd}-\mathrm{Nb}$ plants. The scion length was measured at 30 and 45 dag. Bars in columns indicate standard deviations values between six analyzed samples. (C) Total RNAs were extracted from three different scions at $45 \mathrm{dag}$ and analyzed by Northern blot assays. The HSVd-RNA circular (CM) and linear (LM) monomeric forms levels are significantly similar in symptomless $r d r 6 i-\mathrm{Nb}$ (lanes 1-3) and symptomatic $W t$ $\mathrm{Nb}$ scions (lanes 4-6). (D) SmallRNA enriched RNAs were extracted from three pooled $r d r 6 i$ $\mathrm{Nb}$ and $\mathrm{Wt}-\mathrm{Nb}$ scions at $45 \mathrm{dag}$. The RNAs were analyzed by Northern blot assays, to detect HSVd specifics siRNAs. (E) Total RNAs and small-RNA enriched RNAs were extracted from three pooled $r d r 6 i-N b$ scions and their respective $H S V d-N b$ stocks at 45 dag. The RNAs were diluted $1 / 1$, $1 / 5$ and $1 / 25$ and analyzed by Northern blot assays, to detect mature forms and specifics siRNAs of HSVd. RNAs were quantified by spectrometry and their concentration equalled. $E t B r$ stained gels are shown as RNA load controls (in C, D and E)

The slightly differences in stunting intensity between HSVd-infected $\mathrm{Nb}(\approx$ $80 \%$ of the control) and $H S V d-N b$ plants $(\approx 60 \%$ of the control) maintained at the same temperature can be explained by considering that in transgenic plants the HSVd-RNA input is constitutively provided from the first development stage. Thus, the symptom expression is enhanced in comparison with a conventional pathogenesis processes. 
To check whether the lack of symptoms in the $r d r 6 i-N b$ plants was related with alterations in the accumulation of the HSVd, we analyzed the levels of viroid in inoculated plants. Hybridization assays shown that HSVd accumulated at similar levels in both $\mathrm{Wt}-\mathrm{Nb}$ and $\mathrm{rdr} 6 \mathrm{i}-\mathrm{Nb}$ plants (Figure 4B), indicating that in a conventional pathogenic process the symptom expression is also independent of HSVd accumulation levels but dependent on the RDR6 activity.

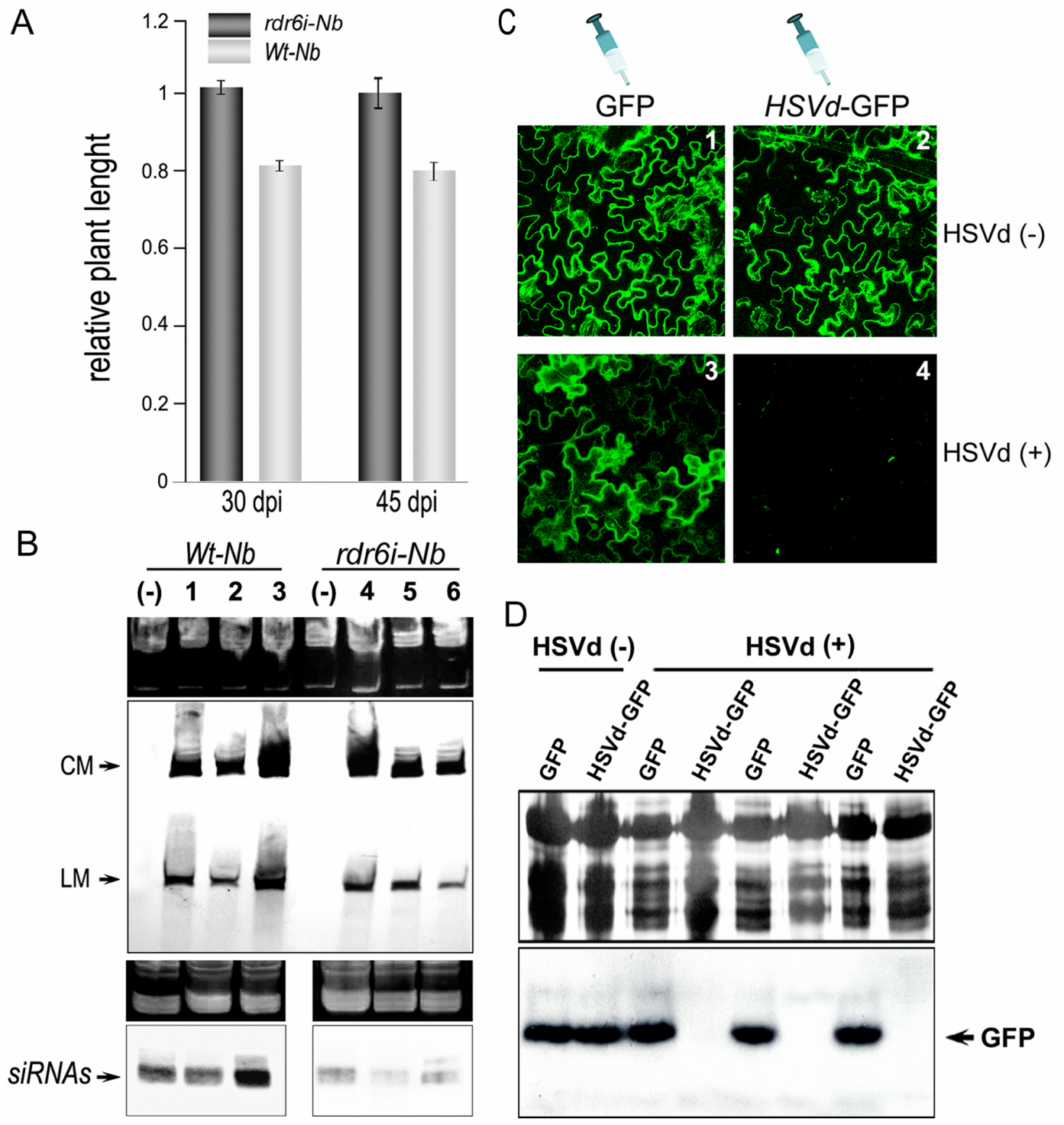

Figure 4. Influence of HSVd on the growing of mechanically infected $\mathrm{Nb}$ plants compared with non-inoculated controls. (A) The relative height with respect to mock-inoculated control, of six $\mathrm{Wt}-\mathrm{Nb}$ and six $r d r 6 i-N b$ HSVdinfected plants was measured at 30 and 45 days post inoculation (dpi). Bars indicate standard deviations values between the analyzed plants. (B) Total RNAs and small-RNA enriched RNAs were extracted from three different symptomatic $\mathrm{Wt}-\mathrm{Nb}$ plants (lanes 1-3) and symptomless $r d r 6 i-\mathrm{Nb}$ plants (lanes 4-6) at 45 dpi and analyzed by Northern blot assays to detect mature forms (upper) and specific siRNAs (lower) of HSVd. RNAs were quantified by spectrometry and their concentration equalled. EtBr stained gels are shown as RNA load controls (C) HSVd-infected $W t-N b$ plants were agroinfiltrated with the HSVd-GFP reporter. As observed in panel 4, the reporter expression is suppressed in symptomatic HSVd-infected $W t-N b$ plants. (D) Detection of HSVd-GFP reporter by Western blot analysis of total proteins extracted from the three HSVd-infected $\mathrm{Wt}-\mathrm{Nb}$ plants. Silver staining gels are shown as protein load controls. 
In coincidence with the results described in the grafting assays, a significant reduction of the HSVd-specific siRNAs concentration was observed in the asymptomatic $r d r 6 i-N b$ when compared with the symptomatic $\mathrm{Wt}$ - $\mathrm{Nb}$ plants (Figure 4B, lower). Next, we went on to determine, by means of agroinfiltration assays, whether the HSVd RNA-induced RNA silencing pathway is active in the infected $N b$ plants. Consistent with the results observed in $H S V d-N b$ plants, the expression of the HSVdGFP reporter was suppressed in the infected $W t-N b$, but not in the uninoculated control plants (Figure 4C and 4D). These results indicate an HSVd-specific RNA silencing activity in the symptomatic $N b$ plants, reinforcing the strong correlation between the activity level of the viroid-specific RNA silencing and the symptom expression observed in the $H S V d-N b$ plants.

\section{DISCUSSION}

Since the discovery of the PSTVd (Diener, 1971), viroids have always been puzzling exceptions to the rules that have been commonly accepted for other plant pathogenic RNAs (Tabler and Tsagris, 2004; Daròs et al., 2006; Flores and Pallás, 2006; Ding and Itaya, 2007). Their genome consists of a naked RNA characterized by the absence of any functional open reading frame. In the "viroid world" however, noncoding does not signify non-functional. Thus, a viroid contains the sufficient genetic information to establish infection in susceptible hosts. Very little information is currently known as to how these sui generis RNAs elicit the pathogenic process.

An emergent view in viroid research links RNA silencing pathway with viroid pathogenesis (Papaefthimiou et al., 2001; Conejero, 2003; Markarian et al., 2004; Wang et al., 2004). Much of the evidence that supports this association is based on the observation of a positive correlation among the levels of small RNAs, the hallmarks of the RNA silencing mechanisms, and symptoms severity (Itaya et al., 2001; Papaefthimiou et al., 2001; Markarian et al., 2004; Matoušek et al., 2007). However this correlation is not fulfilled in some viroid-host combinations (Papaefthimiou et al., 2001; Markarian et al., 2004; Sano and Matsuura, 2004), which raises significant doubts about this attractive hypothesis. The most robust evidence linking RNA silencing and viroid pathogenesis is the observation made by Wang et al (2004) by which tomato plants expressing hairpin RNAs, derived from PSTVd, developed symptoms similar to those of PSTVd infection. Nonetheless, direct evidence of the 
involvement of the RNA silencing pathway in viroid pathogenesis has not yet been reported. Here we present solid evidence that RDR6 must be active for a characteristic pathogenic response due to viroid infection. $N b$ plants that accumulate high levels of HSVd but have a reduced RDR6 expression or that were grown under environmental conditions in which RNA silencing pathway is less efficient did not develop the characteristic stunting induced by the HSVd.

Low temperature has been previously demonstrated to inhibit the RNA silencing-mediated defense (Szittya et al., 2003; Chellappan et al., 2005; Qu et al., 2005). Thus, we analyze the symptom expression in the $H S V d-N b$ plants growing at different temperatures. The $H S V d-N b$ plants kept at $28^{\circ} \mathrm{C}$, which is the optimal temperature for RNA silencing in (Szittya et al., 2003; Chellappan et al., 2005; Qu et $a l ., 2005)$, presented the characteristic symptoms previously described in $\mathrm{Nb}$ plants expressing HSVd (Gómez and Pallás, 2006; Martinez et al, 2008). This phenotypic character was reduced in the $H S V d-N b$ plants kept at $20^{\circ} \mathrm{C}$ and $14^{\circ} \mathrm{C}$ until it eventually disappeared (Figure 1A and 1B), temperatures at which the RNA silencing-based defense has been shown to have a diminished activity in $N b$ plants (Szittya et al., 2003; Qu et al., 2005). Interestingly, the accumulation of circular and linear forms of HSVd was similar in the plants growing at the three different temperatures (Figure 1C). This indicates that the symptoms observed in the $H S V d-N b$ plants growing at $28^{\circ} \mathrm{C}$ do not correlate with HSVd accumulation. These results are in accordance with previous reports showing that, in general, symptoms severity was not correlated with accumulation levels of viroid RNAs (Schnölzer et al., 1985; Gruner et al., 1995; Gora et al., 1996; Rodio et al., 2006). In addition, the symptom expression in Gynura aurantiaca plants infected with CEVd was associated with a specific temperaturesensitive response without any alteration to viroid sequences or structures (Skoric et al., 2001). Although these findings demonstrate a direct relation between temperature and symptoms intensity, irrespectively of genomic HSVd-RNA accumulation, they do not provide evidence to support the involvement of RNA silencing in the viroid-associated pathogenesis process.

The first suggestion showing that the lack of symptom expression in the HSVd$\mathrm{Nb}$ plants grown at lower temperatures should be related to deficiencies in the RNA silencing-based pathway was provided by the results obtained after transitory expression of an HSVd-GFP reporter in the $\mathrm{HSVd}-\mathrm{Nb}$ plants. This reporter was normally expressed in the $H S V d-N b$ plants at $14^{\circ} \mathrm{C}$ (Figure 2A and $2 \mathrm{~B}$ ), indicating that 
the HSVd-specific RNA silencing was inhibited or severely affected in these asymptomatic plants, whereas the reporter was suppressed in symptomatic plants. In addition, a significant reduction in the HSVd-specific siRNAs level was observed in the asymptomatic $H S V d-N b$ plants. These results show a clear association between symptom expression and the activity of the HSVd-specific RNA silencing pathway. However, the possibility that low temperatures would block the direct interaction between the HSVd and cellular factors that serve as targets for symptom expression, cannot be ruled out.

The most robust evidence supporting the involvement of RNA silencing in the expression of HSVd symptoms was provided by the findings obtained in the grafting assays using $H S V d-N b$ plants as stocks, and $\mathrm{Wt}-\mathrm{Nb}$ or $r d r 6 i-\mathrm{Nb}$ plants as scions. Here we demonstrate that the infected $r d r 6 i-N b$ scions were unable to develop HSVdcharacteristic symptoms under identical growing temperature conditions (Figure 3A and $3 \mathrm{~B})$. The symptomless phenotype of the infected $r d r 6 i-N b$ scions contrast with the severe stunting observed in the infected $\mathrm{Wt}-\mathrm{Nb}$ scions grafted onto identical $\mathrm{HSVd}-\mathrm{Nb}$ stocks. Remarkably, this RDR6-dependence to viroid-induced symptoms development was also observed in $\mathrm{Wt}$-Nb plants infected by HSVd-agroinoculation (Figure 4A). Interestingly, while the symptomatic $N b$ plants presented a significant amount of HSVd-specific siRNAs, the symptomless $r d r 6 i-N b$ did not.

Taking into account that the $r d r 6 i-N b$ plants down-regulated the expression of an enzyme playing a key role in S-PTGS and transitive RNA silencing pathway, and that the biogenesis of tasiRNAs and nat-siRNAs is RDR6 dependent, we propose that the asymptomatic phenotype exhibited by these infected plants is a direct consequence of deficiencies in the RNA-mediated silencing mechanism. Interestingly, the accumulation of biological forms of the viroid molecule in RNA silencing-deficient host plants that would not develop symptoms was previously suggested to be a requisite for the pathogenicity model based on the RNA silencing pathway (Tabler and Tsagris, 2004).

An intriguing question that emerges from our results is which of the RDR6dependent pathways could be associated to the expression of viroid-induced symptoms. Several remarkable observations prompt us to speculate that the pathogenic process induced by the viroid-infection could be a consequence of an interference in the regulatory pathway involving tasiRNAs biogenesis, possibly due to fortuitous matches between HSVd-derived siRNAs and the $N$. benthamiana genome. The existence in the 
Nicotiana genus database of sequences presenting a high similarity to specific regions of the HSVd sequence (Supplemental Table 1) is in agreement with this idea. Indeed, both tasiRNA precursors and HSVd-RNA replication-intermediates are nuclear noncoding RNAs dependent on the RNA-Polymerase II activity (Peragine et al., 2004; Allen et al., 2005; Flores et al., 2005). In addition, it has been suggested that tasiRNAs could regulate transcription factors involved in growth, development and flowering in Arabidopsis plants (Remington et al., 2004; Allen et al., 2005; Adenot et al., 2006), resembling the morphological alterations associated to HSVd-infection in diverse hosts (Diener et al., 1988; Shikata, 1990; Martinez et al., 2008). The potential involvement of other relevant players in this regulatory pathway would shed light on the role of the RDR6 in viroid pathogenesis.

In short, our results demonstrate the requirement of RDR6 activity, a key factor in diverse RNA silencing pathways, for the production of viroid-induced symptoms, reinforcing the emergent view that the viroid-specific RNA silencing-based pathway modulates the symptom expression in infected plants (Papaefthimiou et al., 2001; Conejero, 2003; Markarian et al., 2004; Wang et al., 2004 ).

\section{MATERIALS AND METHODS}

\section{Plant material}

The HSVd-transgenic $N$. benthamiana (line $H S V d-N b / 6$ ), expressing and correctly processing dimeric $(+)$ HSVd-cDNA, has been previously described (Gómez and Pallás, 2006). Seeds of $r d r 6 i-N b$ were kindly provided by Dr. D. Baulcombe (Sainsbury Laboratory, John Innes Centre, Norwich, UK). The plants were grown at $28^{\circ} \mathrm{C}$ under natural light with supplementary illumination to maintain a 16-h light period. For temperature treatment, plants were grown in climate boxes (Versatile Environmental Test Chambers; Sanyo, Tokyo, Japan) under a 16-h light $\left(50 \mu \mathrm{E} \mathrm{m} \mathrm{m}^{-2}\right)$ and 8 -h dark regime at $14^{\circ} \mathrm{C}$ and $20^{\circ} \mathrm{C}$.

\section{RNA extraction and Northern blot analysis}

Total RNA was extracted using the TRI reagent (SIGMA, St. Louis, MO, USA) according to the manufacturer's instructions. Briefly, $250 \mathrm{mg}$ of leaves from $\mathrm{Nb}$ plants were ground in $2 \mathrm{ml}$ of TRI reagent, $400 \mu \mathrm{l}$ of chloroform was then added and the sample was vigorously vortexed, followed by centrifugation. The supernatant was 
recovered and the total RNAs were precipitated with isopropanol and resuspended in 50 $\mu l$ of sterile water. The total RNAs preparations were quantified by spectrometry and their concentration was equalled. To analyze the mature forms of HSVd by Northern blot analysis, $1.5 \mu \mathrm{g}$ of the total RNA preparations were electrophoresed under denaturing conditions in a 5\% polyacrylamide gel, $0.25 \times$ TBE, $8 \mathrm{M}$ urea (Pallás et al., 1987). The RNA was blotted to nylon membranes (ROCHE Diagnostics GmbH, Manneiheim, Germany), and hybridized as previously described (Gómez and Pallás, 2007).

To analyze the small RNAs, total nucleic acids were extracted from $4 \mathrm{~g}$ of leaves as previously described. The pellets obtained were used as starting material to purify the small RNAs $(<200 \mathrm{nt}$ ) enriched for siRNA using miRACLE (miRNA isolation Kit, STRATAGENE) according to the manufacturer's instructions. Equal amounts of small RNAs (25 $\mu \mathrm{g})$ were loaded onto $20 \%$ polyacrylamide gel, $0.25 \mathrm{x} \mathrm{TBE}$, $8 \mathrm{M}$ urea. The RNA was transferred to nylon membranes (ROCHE Diagnostics GmbH, Manneiheim, Germany). Hybridization was performed at $32.5^{\circ} \mathrm{C}$ for $14-16 \mathrm{~h}$, using a Digoxigenin-labelled negative strand-specific HSVd-RNA as a probe. The membrane was washed with $2 \mathrm{x} \mathrm{SSC}, 0.1 \% \mathrm{SDS}$ for $15 \mathrm{~min}$ at $24^{\circ} \mathrm{C}$ and for $15 \mathrm{~min}$ at $32.5^{\circ} \mathrm{C}$. Chemiluminescent detection was performed as previously described (Gómez and Pallás, 2007).

\section{Agroinfiltration}

Binary pMOG800 plasmids carrying the HSVd-GFP reporter (Gómez and Pallás, 2007b) were transformed into the Agrobacterium tumefaciens strain C58C1 (Hamilton et al., 1996). The $N b$ plants were agroinfiltrated in basal leaves as previously described (Gómez and Pallás, 2007). Three days after agroinfiltration, leaf discs (3 per leaves) were obtained. The GFP expression was analyzed with a Leica TCS SL confocal laser-scanning microscope, with excitation at $488 \mathrm{~nm}$ and emission at 510 $560 \mathrm{~nm}$ and by western blot assays as previously described (Gómez and Pallás, 2007).

\section{Agroinoculation}

The $\mathrm{Nb}$ plants were agroinoculated with Agrobacterium tumefaciens strain C58C1 transformed with a binary pMOG800 vector carrying a head-to-tail infectious dimeric HSVd cDNA (Gómez and Pallás, 2006) as previously described (Carbonell et $a l ., 2008)$. The agroinfiltrated leaves were eliminated at 6 days post infiltration (dpi). 
The plants were maintained in environmentally controlled growing chamber at $30^{\circ} \mathrm{C}$ for $16 \mathrm{~h}$ with fluorescent light and at $25^{\circ} \mathrm{C}$ for $8 \mathrm{~h}$ in darkness and analyzed at 30 and 45 dpi.

\section{Grafting assays}

Two week-old $W t-N b$ and $r d r 6 i-N b$ scions were cut to a wedge shape that was then inserted into a vertical slit cut into $H S V d-N b / 6$ and Wt- $\mathrm{Nb}$ stocks. The grafting junction was wrapped with Parafilm ${ }^{\mathrm{TM}}$ and grafted plants were kept at $22^{\circ} \mathrm{C}$ for ten days under controlled humidity conditions under plastic cover, and were later moved to environmentally-controlled growth chambers $\left(28^{\circ} \mathrm{C} / 14 \mathrm{~h}\right.$ light $)$. The scion length was measured at 30 and 45 days after grafting (dag). Total RNAs were obtained from the excised scions and stocks as described above.

\section{ACKNOWLEDGMENTS}

We thank Dr D. Baulcombe for providing the seeds of RDR6i-Nb and Drs. C. Llave, S.F. Elena and J.A. Daròs for their valuable contribution in the critical reading of the manuscript. We are indebted to Dr. M.D. Gómez-Jimenez for assistance in the observation of GFP expression with a confocal microscope. We also thank to an anonymous reviewer his/her valuable suggestions. 


\section{LITERATURE CITED}

Adenot X, Elmayan T, Lauressergues D, Boutet S, Bouché N, Gasciolli V, Vaucheret H (2006) DRB4-dependent TAS3 trans-acting siRNAs control leaf morphology through AGO7. Curr Biol 16: 927-932

Allen E, Xie Z, Gustafson AM, Carrington JC (2005) microRNA-directed phasing during trans-acting siRNA biogenesis in plants. Cell 121: 207-221

Baulcombe DC (2002) RNA silencing. Curr Biol 12: 82-84

Brodersen P, Voinnet $\mathbf{O}$ (2006) The diversity of RNA silencing pathways in plants. Trends Genet 22: 268-280

Carbonell A, Martínez de Alba AE, Flores R, Gago S (2008) Double-stranded RNA interferes in a sequence-specific manner with the infection of representative members of the two viroid families. Virology 371: 44-53

Chapman EJ, Carrington JC (2007) Specialization and evolution of endogenous small RNA pathways. Nat Rev Genet 8: 884-896

Chellappan P, Vanitharani R, Ogbe F, Fauquet CM (2005) Effect of temperature on geminivirus-induced RNA silencing in plants. Plant Physiol 138: 1828-1841

Conejero V (2003) in Viroids, eds Hadidi A, Flores R, Randles JW, Semancik JS (CSIRO Publishing, Collingwood, Australia), pp 67-70

Dalmay T, Hamilton A, Rudd S, Angell S, Baulcombe DC (2000) An RNADependent RNA polymerase gene in Arabidopsis is required for posttranscriptional gene silencing mediated by a transgene but not by a virus. Cell 101: 543-553

Daròs JA, Flores R (2002) A chloroplast protein binds a viroid RNA in vivo and facilitates its hammerhead-mediated self-cleavage. EMBO J 21: 749-759

Daròs JA, Elena SF, Flores R (2006) Viroids: an Ariadne's thread into the RNA labyrinth. EMBO Rep 7: 593-598.

Diener TO (1971) Potato spindle tuber "virus" Replicating, low molecular weight RNA. Virology 45:411-428

Diener TO, Smith D, Hammond R, Albanese G, La Rosa R, Davino M (1988) Citrus B viroid identified as a strain of hop stunt viroid. Plant Disease 72: 691-693 
Diener TO (1999) Viroids and the nature of viroid diseases. Arch Virol 15: 203-220

Ding B, Itaya A (2007) Viroid: A useful model for studying the basic principles of infection and RNA biology. Mol Plant-Microbe Interact 20: 7-20

Ding SW, Voinnet O (2007) Antiviral immunity directed by small RNAs. Cell 130: 413-426

Flores R, Delgado S, Gas ME, Carbonell A, Molina D, Gago S, de la Peña M (2004) Viroids: the minimal non-coding RNAs with autonomous replication. FEBS Letters 567: $42-48$

Flores R, Hernández C, Martínez de Alba AE, Daròs JA, Di Serio F (2005) Viroids and viroid-host interactions. Ann Rev Phytopathol 43: 117-139

Flores R, Pallás V (2006) in Handbook of Plant Virology, eds Khan JA, Dijkstra J (The Haworth Press Inc New York), pp 93-104

Gómez G, Pallás V (2001) Identification of an in vitro ribonucleoprotein complex between a viroid RNA and a phloem protein from cucumber plants. Mol Plant-Microbe Interact 14: 910-913

Gómez G, Pallás V (2004) A long-distance translocatable phloem protein from cucumber forms a ribonucleoprotein complex in vivo with Hop stunt viroid RNA. J Virol 78: 10104-10110

Gómez G, Pallás V (2006) Hop stunt viroid is processed and translocated in transgenic N. benthamiana plants. Mol Plant Pathol 7: 511-517

Gómez G, Pallás V (2007) Mature monomeric forms of Hop stunt viroid resist RNA silencing in transgenic plants. Plant J 51: 1041-1049

Gómez G, Pallás V (2007b) A peptide derived from a single-modified viroid-RNA can be used as an "in vivo" nucleolar marker. J Virol Methods 144: 169-171

Gómez G, Torres H, Pallás V (2005) Identification of translocatable RNA-binding phloem proteins from melon, potential components of the long-distance RNA transport system. Plant J 41: 107-116

Gora A, Candresse T, Zagorski W (1996) Use of intramolecular chimeras to map molecular determinants of symptom severity of Potato spindle tuber viroid. Arch Virol 141: $2045-2055$ 
Gruner R, Fels A, Qu F, Zimmat R, Steger G, Riesner D (1995) Interdependence of pathogenicity and replicability with Potato spindle tuber viroid. Virology 209: 60-69

Hamilton CM, Frary A, Lewis C, Tanksley SD (1996) Stable transfer of intact high molecular weight DNA into plant chromosomes. Proc Natl Acad Sci USA 93: 99759979

Himber C, Dunoyer P, Moissiard G, Ritzenthaler C, Voinnet O (2003) Transitivitydependent and -independent cell-to-cell movement of RNA silencing. EMBO J 22: $4523-4533$

Hull R (2002) in Matthews` Plant Virology- Fourth Edition (Academic Press San Diego)

Itaya A, Folimonov A, Matsuda Y, Nelson RS, Ding B (2001) Potato spindle tuber viroid as inducer of RNA silencing in infected tomato. Mol Plant-Microbe Interact 14: $1332-1334$

Itaya A, Zhong X, Bundschuh R, Qi Y, Wang Y, Takeda R, Harris AR, Molina C, Nelson RS, Ding B (2007) A structured viroid RNA Is substrate for Dicer-Like cleavage to produce biologically active small RNAs but is resistant to RISC-mediated degradation. J Virol 81: 2980-2994

Llave C, Kasschau KD, Rector MA, Carrington JC (2002) Endogenous and silencing-associated small RNAs in plants. Plant Cell 14: 1605-1619

Markarian N, Li HW, Ding SW, Semancik JS (2004) RNA silencing as related to viroid induced symptom expression. Arch Virol 149: 397-406

Martín R, Arenas C, Daròs JA, Covarrubias A, Reyes JL, Chua N (2007) Characterization of small RNAs derived from Citrus exocortis viroid in infected tomato plants. Virology 367: 135-146

Martínez de Alba AE, Flores R, Hernández C (2002) Two chloroplastic viroids induce the accumulation of the small RNAs associated with post-transcriptional gene silencing. J Virol 76:13094-13096

Martinez G, Pallás V, Gómez G (2008) Analysis of the symptoms developed in $N$. benthamiana plants expressing dimeric forms of the Hop stunt viroid. J Plant Pathol 90: $121-124$ 
Matoušek J, Kozlová P, Orctová L, Schmitz A, Pesina K, Bannach O, Diermann N, Steger G, Riesner D (2007) Accumulation of viroid-specific small RNAs and increase in nucleolytic activities linked to viroid-caused pathogenesis. Biol Chem 388: 1-13

Mourrain P, Beclin C, Elmayan T, Feuerbach F, Godon C, Morel JB, Jouette D, Lacombe AM, Nikic S, Picault N, Remoue K, Sanial M, Vo TA, Vaucheret H (2000) Arabidopsis SGS2 and SGS3 genes are required for posttranscriptional gene silencing and natural virus resistance. Cell 101: 533-542

Owens RA, Blackburn M, Ding B (2001) Possible involvement of the phloem lectin in long-distance viroid movement. Mol Plant-Microbe Interact 14: 905-909

Papaefthimiou I, Hamilton AJ, Denti MA, Baulcombe DC, Tsagris M, Tabler M (2001) Replicating Potato spindle tuber viroid RNA is accompanied by short RNA fragments that are characteristic of post-transcriptional gene silencing. Nucl Acids Res 29: $2395-2400$

Peragine A, Yoshikawa M, Wu G, Albrecht HL, Poethig RS (2004) SGS3 and SGS2/SDE1/RDR6 are required for juvenile development and the production of transacting siRNAs in Arabidopsis. Genes Dev 18: 2368-2379

Qu F, Ye XH, Hou GC, Sato S, Clemente TE, Morris TJ (2005) RDR6 has a broadspectrum but temperature-dependent antiviral defense role in $\mathrm{N}$. benthamiana. J Virol 79: $15209-15217$

Remington DL, Vision TJ, Guilfoyle TJ, Reed JW (2004) Contrasting modes of diversification in the Aux/IAA and ARF gene families. Plant Physiol 135:1738-1752

Rodio ME, Delgado S, Flores R, Di Serio F (2006) Variants of Peach latent mosaic viroid inducing peach calico: uneven distribution in infected plants and requirements of the insertion containing the pathogenicity determinant. J Gen Virol 87: 231-240

Sano T, Matsuura Y (2004) Accumulation of short interfering RNAs characteristics of RNA silencing precedes recovery of tomato plants from severe symptoms of Potato spindle tuber viroid infection. J Gen Plant Pathol 70: 50-53

Schnölzer M, Haas B, Ramm K, Hofmann H, Sänger HL (1985) Correlation between structure and pathogenicity of Potato spindle tuber viroid (PSTV). EMBO J 4: $2181-2190$

Schwach F, Vaistij FE, Jones L, Baulcombe DC (2005) An RNA-dependent RNA 
polymerase prevents meristem invasion by potato virus $\mathrm{X}$ and is required for the activity but not the production of a systemic silencing signal. Plant Physiol 138: 18421852

Shikata E (1990) New viroids from Japan. Seminars in Virology 1: 107-115

Skoric D, Conerly M, Szychowski JA, Semancik JS (2001) CEVd-induced symptom modification as a response to a host-specific temperature-sensitive reaction. Virology 280: $115-123$

Szittya G, Silhavy D, Molnar A, Havelda Z, Lovas A, Lakatos L, Banfalvi Z, Burgyan J (2003) Low temperature inhibits RNA silencing-mediated defence by the control of siRNA generation. EMBO J 22: 633-640

Tabler M, Tsagris M (2004) Viroids: petite RNA pathogens with distinguished talents. Trends Plant Sci 9: 339-348

Vance V, Vaucheret H (2001) RNA silencing in plants-defense and counterdefense. Science 292: 2277-2280

Vaistij FE, Jones L, Baulcombe DC (2002) Spreading of RNA targeting and DNA methylation in RNA silencing requires transcription of the target gene and a putative RNA-dependent RNA polymerase. Plant Cell 14: 857-867

Vaucheret H (2006) Post-transcriptional small RNA pathways in plants: mechanisms and regulations. Genes Dev 20: 759-771

Vazquez F, Vaucheret H, Rajagopalan R, Lepers C, Gasciolli V, Mallory AC, Hilbert JL, Bartel DP, Crété P (2004) Endogenous trans-acting siRNAs regulate the accumulation of Arabidopsis mRNAs. Mol Cell 16: 69-79

Vogt U, Pelissier T, Putz A, Razvi F, Fischer R, Wassenegger M (2004) Viroidinduced RNA silencing of GFP-viroid fusion transgenes does not induce extensive spreading of methylation or transitive silencing. Plant J 38: 107-118

Wang MB, Bian XY, Wu LM, Liu LX, Smith NA, Isenegger D, Wu RM, Masuta C, Vance VB, Watson JM, Rezaian A, Dennis ES, Waterhouse PM (2004) On the role of RNA silencing in the pathogenicity and evolution of viroids and viral satellites. Proc Natl Acad Sci USA 101: 3275-3280 
Xu L, Yang L, Pi L, Liu Q, Ling Q, Wang H, Poethig RS, Huang H (2006) Genetic interaction between the AS1-AS2 and RDR6-SGS3-AGO7 pathways for leaf morphogenesis. Plant Cell Physiol 47: 853-863 
SUPPLEMENTAL DATA

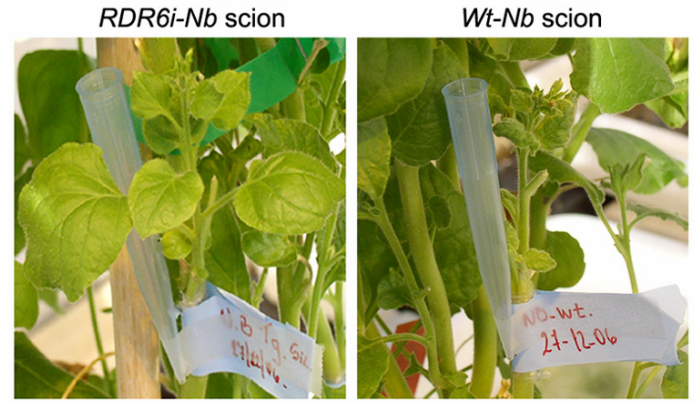

HSVd-Nb (6-1) Stock

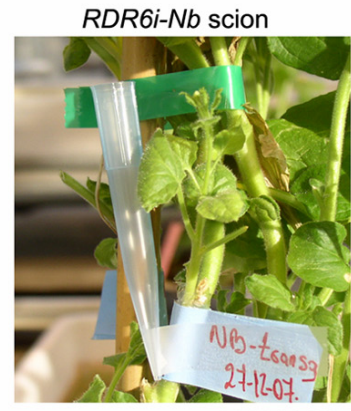

HSVd-Nb (6-3) Stock
RDR6i-Nb scion
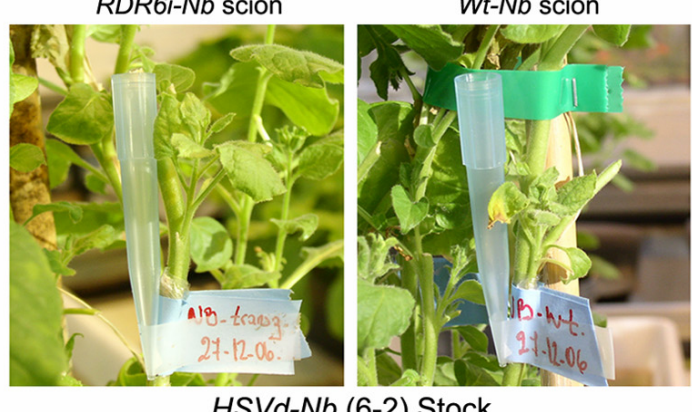

HSVd-Nb (6-2) Stock

Wt-Nb scion

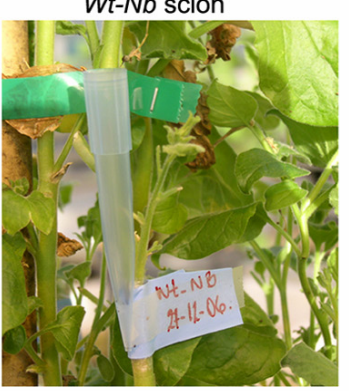

Sin

Supplemental figure1. General view of $\mathrm{Wt}-\mathrm{Nb}$ and rdr6i-Nb scions at 17 days after grafting. Two week-old $\mathrm{Wt}-\mathrm{Nb}$ and rdr6i-Nb scions were grafted onto symptomatic transgenic $\mathrm{HSVd}-\mathrm{Nb}$ stocks, and kept at $28^{\circ} \mathrm{C}$. General symptoms induced by HSVd in diverse $\mathrm{Wt}-\mathrm{Nb}$ scion compared with rdr6i-Nb scions grafted onto identical stocks at 17 days after grafting.

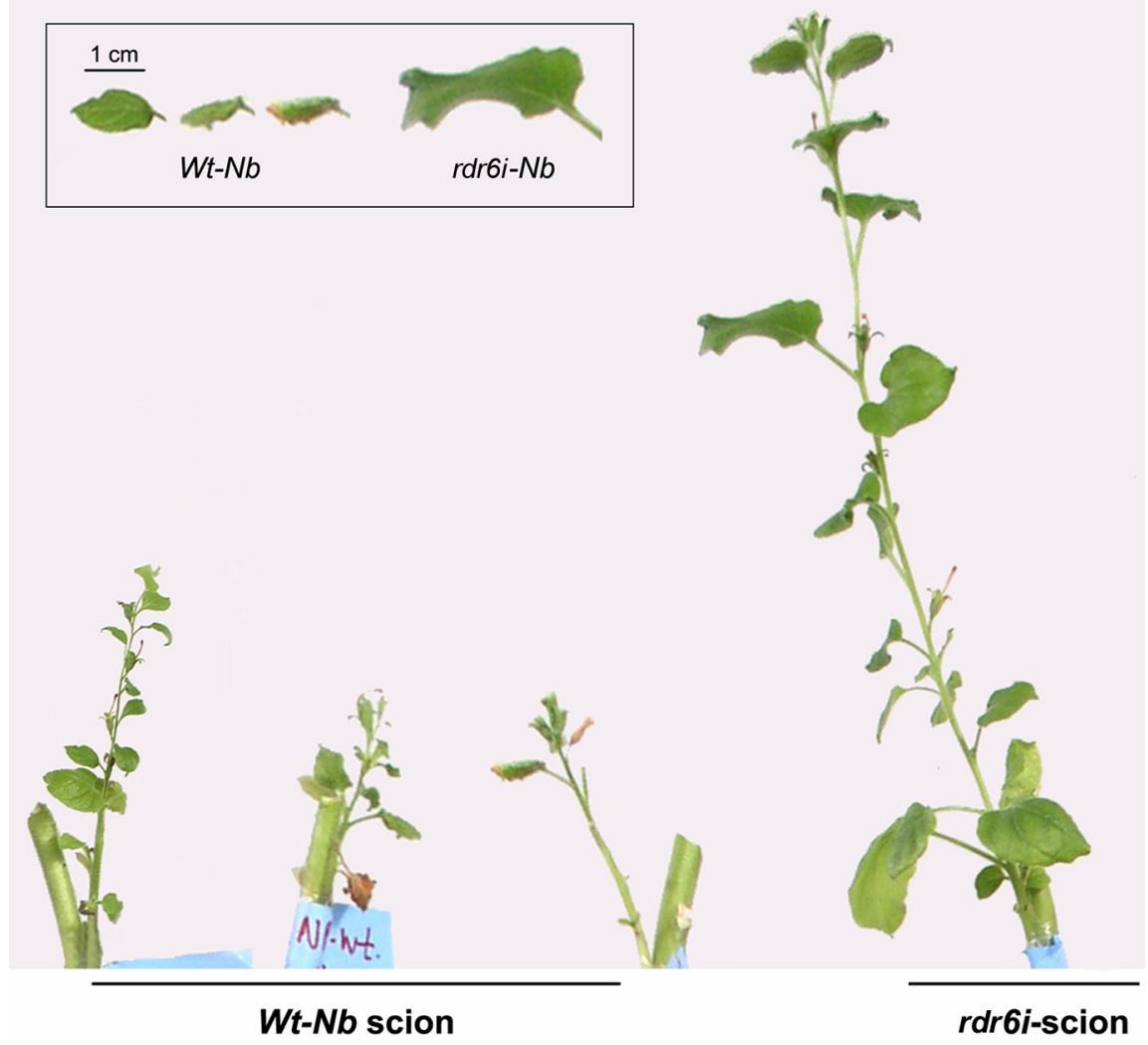

Supplemental figure 2. Symptoms induced by HSVd in diverse Wt-Nb scion compared with a representative rdr6i$\mathrm{Nb}$ scion at 45 days after grafting. The upper panel (B) showed a magnified image of the representative leaves of Wt$\mathrm{Nb}$ and rdr6i-Nb scions. In the leaves of the $\mathrm{Wt}-\mathrm{Nb}$ scion, the size reduction and chlorosis followed by necrosis are seen, as described in the text. 


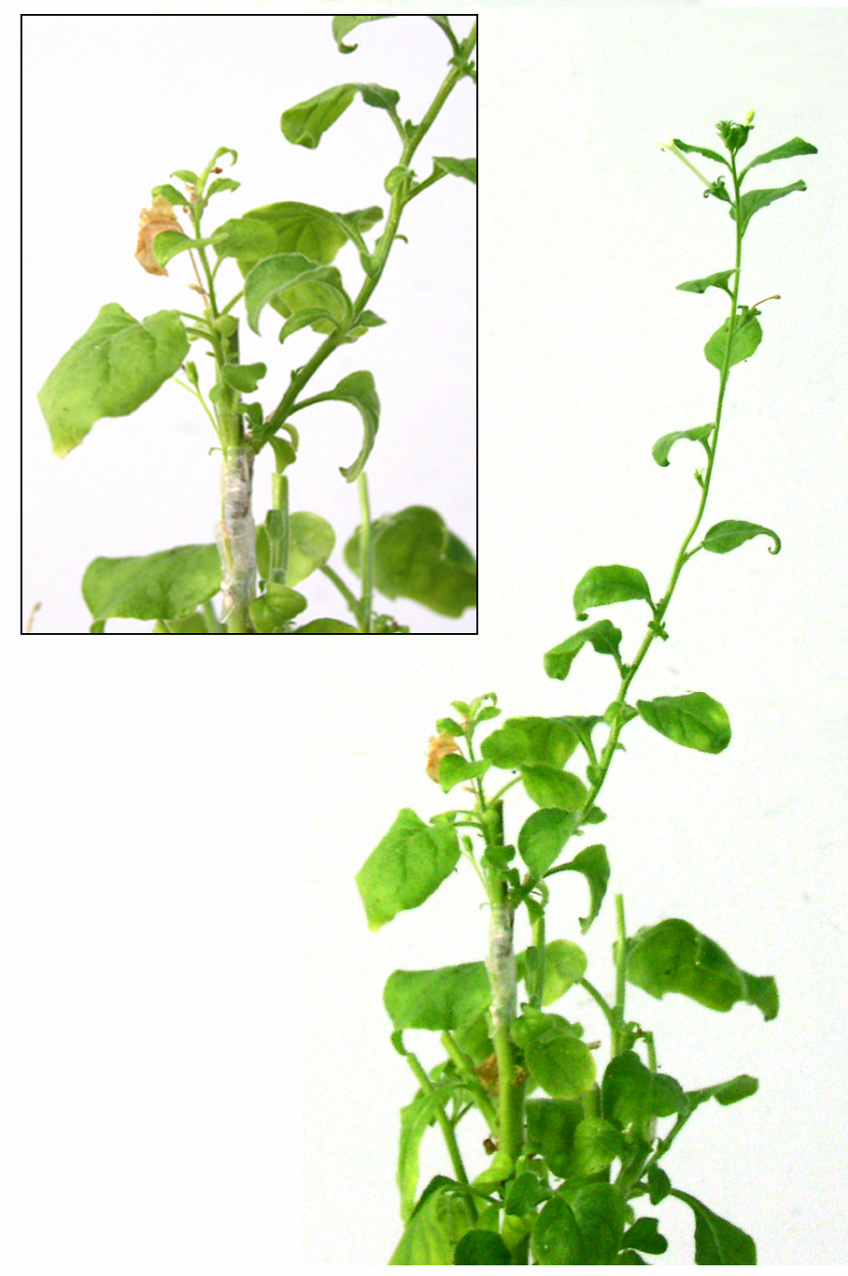

Supplemental figure 3. Symptoms induced by HSVd in a Wt-Nb scion compared with a rdr6i-Nb scion at 45 days after grafting onto the same HSVd-Nb (stock) branch. The insert panel shows a magnified image of the graft; the size reduction and chlorosis followed by necrosis are coincident with those observed in the other grafts described in the text.

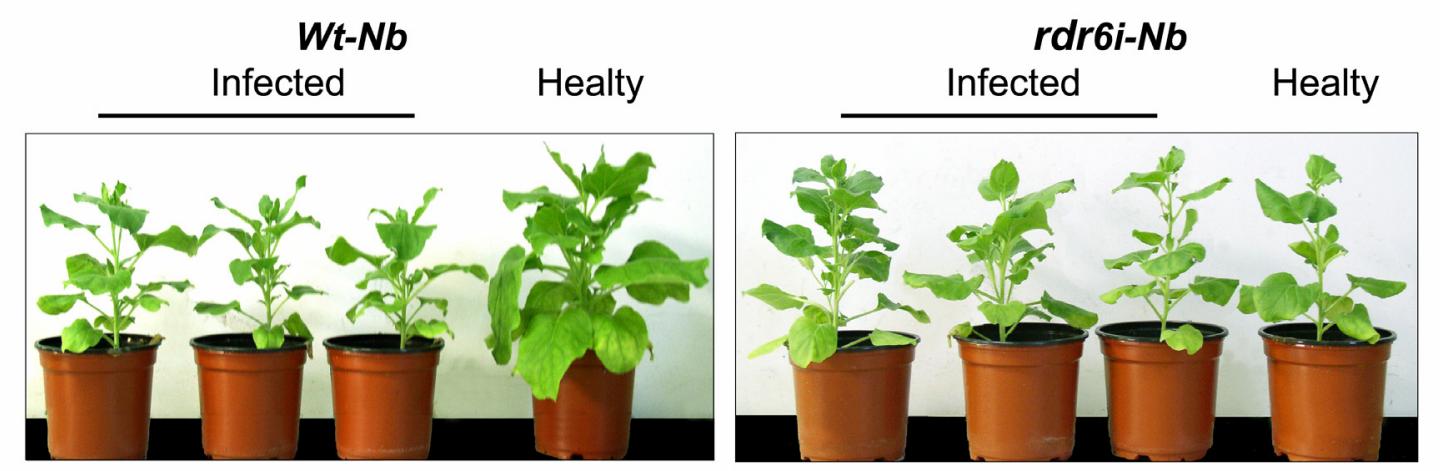

Supplemental figure 4. Stunting and severe leaves size reduction induced by HSVd in Wt-Nb plants compared with asymptomatic infected rdr6i-Nb plants at 45 days post inoculation. 
Capitulo III 


\title{
High-throughput sequencing of Hop stunt viroid-derived small RNAs from cucumber leaves and phloem
}

\author{
Martínez $\mathbf{G}^{\mathbf{1}}$, Donaire $\mathbf{L}^{\mathbf{2}}$, Llave $\mathbf{C}^{\mathbf{2}}$, Pallás $\mathbf{V}^{\mathbf{1}}$ and Gómez $\mathbf{G}^{\mathbf{1}}$. \\ 1. Instituto de Biología Molecular y Celular de Plantas, Consejo Superior de \\ Investigaciones Científicas-UPV, CPI, Edificio 8 E, Av. de los Naranjos s/n, \\ 46022 Valencia, Spain \\ 2. Centro de Investigaciones Biológicas, Consejo Superior de Investigaciones \\ Científicas, Ramiro de Maeztu 9, 28040 Madrid, Spain
}

Molecular Plant Pathology 11 (3), 347-359 (2010)

\begin{abstract}
Small RNA (sRNA)-guided processes, referred to as RNA silencing, regulate endogenous and exogenous gene expression. In plants and some animals, these processes are noncell autonomous and can operate beyond the site of initiation. Viroids, the smallest self-replicating plant pathogens known, are inducers, targets and evaders of this regulatory mechanism and, consequently, the presence of viroid-derived sRNAs (vd-sRNAs) is usually associated with viroid infection. However, the pathways involved in the biogenesis of vd-sRNAs are largely unknown. Here, we analyse, by high-throughput pyrosequencing, the profiling of the Hop stunt viroid (HSVd) vd-sRNAs recovered from the leaves and phloem of infected cucumber (Cucumis sativus) plants. HSVd vd-sRNAs are mostly 21 and 22 nucleotides in length and derived equally from plus and minus HSVd RNA strands. The widespread distribution of vd-sRNAs across the genome reveals that the totality of the HSVd RNA genome contributes to the formation of vd-sRNAs. Our sequence data suggest that viroid-derived double-stranded RNA functions as one of the main precursors of vd-sRNAs. Remarkably, phloem vd-sRNAs accumulated preferentially as 22 -nucleotide species with a consensus sequence over-represented. This bias in size and sequence in the HSVd vd-sRNA population recovered from phloem exudate suggests the existence of a selective trafficking of vd-sRNAs to the phloem tissue of infected cucumber plants.
\end{abstract}




\section{INTRODUCTION}

RNA silencing is a pan-eukaryotic sequence-specific mechanism that plays a relevant role in control of genome stability, development and response to biotic and abiotic stress (Baulcombe, 2004; Vaucheret, 2006). In plants these RNA-dependent regulatory phenomena share four basic steps, $i$ ) double-stranded RNA (dsRNA) generation, ii) cleavage of ds-RNAs into 21- to 24-nt small RNA (sRNAs) duplexes, iii) stabilization of sRNAs by $2^{\prime}$-O-methylation of the 3 '-overhang ends, and $i v$ ) loading of sRNAs into RNA-induced silencing complexes that mediate the association with partial or fully complementary RNA or DNA targets (Ruiz-Ferrer and Voinnet; 2009). The dsRNA can be originated by any of several mechanisms that include intramolecular base-pairing of self-complementary regions from endogenous and/or exogenous RNAs, and transcription of transposons and (sense or inverted-repeat) transgenes. In plants, dsRNA is also synthesized by RNA-dependent RNA polymerases (RDRs) using singlestranded RNAs with aberrant molecular features as templates (Ruiz-Ferrer and Voinnet, 2009; Voinnet, 2008). Arabidopsis encodes six RDRs (RDR1-6), although dsRNA generation activity has been only described or suggested for RDR1, RDR2 and RDR6 (Qi et al., 2009; Schiebel et al., 1998; Wassenegger and Krczal, 2006). Doublestranded RNA is processed into sRNAs by RNase III-type enzymes called Dicer-like proteins (DCLs). In Arabidopsis, four DCLs (DCL1 to 4) act in a hierarchical way to generate 21- to 24-nt sRNAs, the key guide of the regulatory processes mediated by RNA silencing (Ramachandran and Chen, 2008).

In plants, the effects of RNA silencing extend beyond its sites of induction by cell to cell movement (local spreading) and also over longer distances to apical tissues (systemic spreading) due to the movement of the signaling molecules (Brosnan et al., 2007; Dunoyer and Voinnet, 2008). Although it has been established that the systemic movement shows a source-to-sink pattern thorough the phloem (Palauqui et al., 1997), the mechanism underlying long-distance transmission of RNA silencing and the precise identity of the transported signal have remained elusive. The identification of sRNAs in the phloem of cucurbit (Yoo et al., 2004) and brassica (Buhtz et al., 2008) species argues for their long distance mobility, probably mediated by specific RNA-binding proteins (Yoo et al., 2004). Although the accumulation of different sRNAs in vascular tissue leads to suggest that they could be the mobile silencing signals (Aung et al., 2006; Bari et al., 2006; Buhtz et al., 2008; Valoczi et al., 2006) direct evidence of their involvement in long distance RNA silencing spread are still lacking. 
Viroids are the smallest (246-401 nt) self-replicating plant pathogens known to date. Their genome consists of single-stranded, covalently closed, circular and highly structured RNA (Darós et al., 2006; Ding, 2009; Flores et al., 2005; Tsagris et al., 2008). These plant-pathogenic RNAs are unable to code for proteins and therefore, their life cycle is strictly dependent on host factors. Viroids are classified into two families: the Pospiviroidae, whose replication takes place in the nucleus, and the Avsunviroidae, that replicates (and accumulate) in the chloroplast (Darós et al., 2006; Ding, 2009; Flores et al., 2005; Tsagris et al., 2008). The detection of viroid-derived sRNAs (vd-sRNAs) in diverse hosts indicates that viroids are potential activators of RNA silencing in infected plants (Carbonell et al., 2008; Gomez and Pallas, 2007; Itaya et al., 2001; Markarian et al., 2004;- Martinez de Alba et al., 2002; Papaefthimiou et al., 2001; St-Pierre et al., 2009; Vogt et al., 2004; Wang et al., 2004). Moreover, the demonstration that mature forms of Potato spindle tuber viroid (PSTVd) and Hop stunt viroid (HSVd) can simultaneously elicit and resist this plant defense mechanism in tomato (Itaya et al., 2007) and Nicotiana benthamiana (Gomez and Pallas, 2007) plants have provided a unified picture in which these non-coding RNAs are inductors, potential targets, and evaders of RNA silencing at the same time. In addition, the possibility that viroid-induced RNA silencing could be associated with symptom expression in infected plants is currently accepted as a plausible hypothesis to explain the pathogenesis process induced by nuclear viroids (Gomez et al., 2008; Gomez et al., 2009; Markarian et al., 2004; Matousek et al., 2007; Papaefthimiou et al., 2001; Wang et al., 2004). Although it is highly probable that viroid-induced RNA silencing could be translocated systemically through the plant, experimental approaches addressing this question are currently inexistent. Likewise, although the association between diseases induced by nuclear-viroids and accumulation of specific sRNAs has been established for several host-viroid interactions, little is known about how the RNA silencing machinery targets the viroidal genome to produce vd-sRNAs (Ding, 2009).

Here we report the first high-resolution map of sRNAs derived from Hop stunt viroid (HSVd) from leaf and phloem tissue of infected cucumber plants to understand the biogenesis pathways of vd-sRNAs and their potential as signaling molecules of systemic RNA silencing. Deep sequencing analysis of viroid-specific, 21- to 24-nt sRNA species, shows that: a) vd-sRNAs were predominantly $21 \mathrm{nts}$ in length, b) sense and antisense vd-sRNAs accumulated at similar levels in infected plants, and c) vdsRNA reads spread throughout the entire plus and minus HSVd RNA. Remarkably, vd- 
sRNAs of $22 \mathrm{nts}$ were shown to accumulate differentially in the phloem sap of infected cucumber plants, suggesting the existence of a selective trafficking of sRNAs from non-vascular cells to phloem.

\section{RESULTS}

\section{Characterization of vd-sRNAs}

Profiling of vd-sRNAs can help to decipher the mechanisms and components involved in their biogenesis. Consequently, we used a sRNA high-throughput sequencing approach to analyze and characterize the viroid-specific sRNAs population in HSVd-infected cucumber (Cucumis sativus) plants, including leaves and phloem. The interaction HSVd-cucumber was selected because HSVd, previously reported as a RNA silencing inducer in N. benthamiana plants (Gomez et al., 2008; Gomez and Pallas, 2007), infects systemically cucumber plants. In addition, cucumber constitutes a well-known biological model from which analytical quantities of phloem sap can be easily collected (Gomez et al., 2005; Yoo et al., 2004).

Systemically infected (5-6 weeks post inoculation) and healthy cucumber plants were used as the source material for RNA purification and sRNAs library construction. Viroid mature forms were readily detected by Northern blot assays in cucumber leaves and phloem exudates using a HSVd-specific probe (Fig. 1a), suggestive of a widespread distribution of HSVd in infected cucumber plants. RNA hybridization assays also revealed a significant accumulation of HSVd-specific sRNAs in leaves and phloem exudate of infected cucumber plants (Fig. 1b). These results provide evidence that, similar to that previously reported in N. benthamiana (Gomez and Pallas, 2007), HSVd induces an RNA silencing response in infected cucumber plants. The clear detection of vd-sRNAs in phloem exudate indicates that these RNAs accumulate in this plant tissue at sufficient levels to be easily characterized (Fig. 1b). We observed that both viroid RNA and Ribulose Bisphosphate Carboxilase/Oxigenase (rubisco)-specific mRNA accumulated to high levels in leaves (Fig. 1c). In contrast, viroid RNA but not rubisco mRNA accumulated in phloem exudates (Fig. 1c). These controls discarded the possibility that our phloem samples were contaminated with the content of photosynthetic cells unrelated to mature transporting sieve elements. 
A

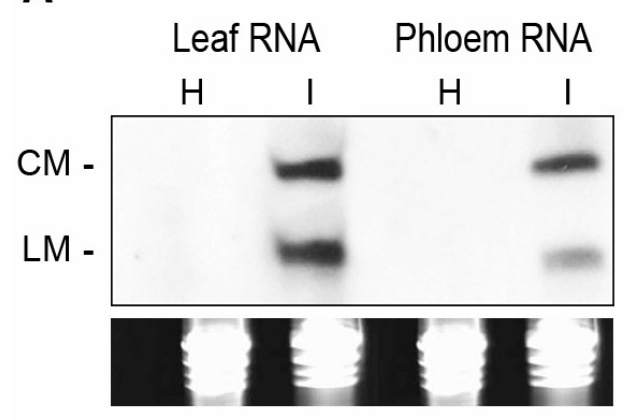

B

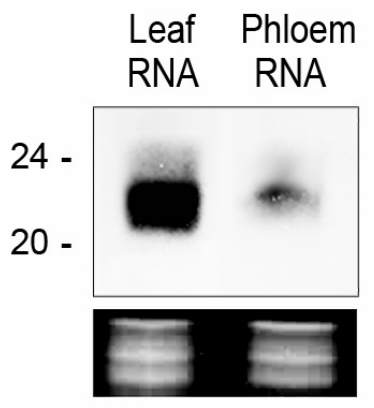

C

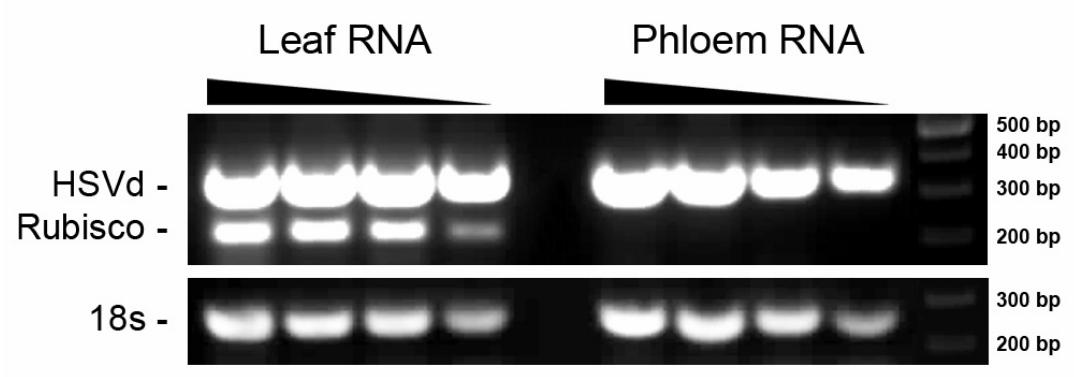

Fig. 1 Analysis of cucumber RNAs.

A) Northern blot assays of total RNA extracted from leaves and phloem exudates of infected plants grown at $30^{\circ} \mathrm{C}$. The circular (CM) and linear (LM) monomeric forms of HSVd were detected in both tissues. B) Small-RNA enriched RNAs extracted from leaves and phloem were analyzed by Northern blot assays to detect HSVd-specific siRNAs. RNAs were quantified by spectrometry and their concentration equalled. EtBr stained gels are shown as RNA load controls (in A and B). C) Total RNAs extracted from cucumber leaves and phloem were analyzed by RT-PCR for the presence of the photosynthetic related mRNA ribulose bisphosphate carboxilase/oxigenase (rubisco) and electrophoresed in 1\% agarose gel. Fragments of $\sim 300 \mathrm{bp}$ of the HSVd and the 18s RNA ( $\sim 200 \mathrm{bp})$ were amplified by RT-PCR in both tissues, whereas the rubisco mRNA (fragment amplified of $\sim 220 \mathrm{bp}$ ) was not amplified in the phloem sample.

A pool of sRNAs enriched from total RNA preparations were extracted from leaves and phloem sap of infected and healthy cucumber plants, ligated to $5^{\prime}$ and 3' adapters, amplified by RT-PCR and subjected to multiplexed pyrosequencing. Adapters were designed to specifically ligate sRNAs containing 5'monophosphate and 3'hydroxyl ends, consistent with DCL-catalyzed cleavage products (Kasschau et al., 2007). A total of 136,592 and 78,374 raw sequences were obtained from infected and healthy cucumbers respectively. Removal of sequence tags with incomplete matching to the $5^{\prime}$ - or $3^{\prime}$ - adapter or resulting from adapter self-ligation yielded a set of 127,347 $(93.23 \%)$ and $72,932(93.05 \%)$ high quality sequence tags, each containing a sRNAs insert with perfectly matched adapters in the expected configuration (Fig. 2a). The retrieving of a low proportion of rRNA-derived ncRNAs was recently suggested as a good indicator of RNA sample quality in conventional sequencing of PLMVd-derived siRNAs (St-Pierre et al., 2009). In consequence, plant-endogenous sRNAs recovered from infected and healthy cucumber were analyzed by pairwise alignment using the 
available database of ribosomal RNA sequences of members of Cucumis genus. The low proportion of unique sRNAs fully homologous to rRNA recovered from infected $(11.80 \%)$ and healthy (7.95\%) cucumber plants (Fig. 2b), was assumed as an indirect indicator of RNA sample integrity.

A

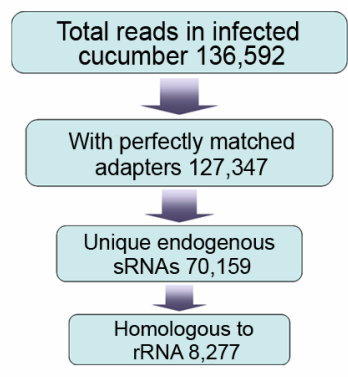

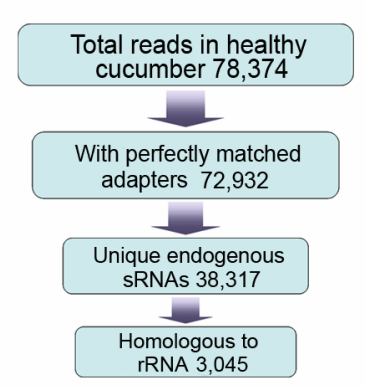

B

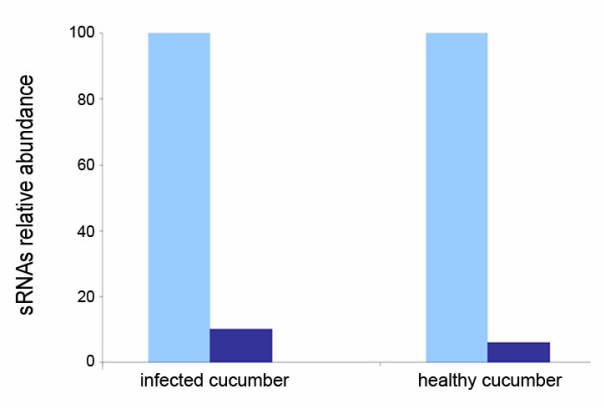

Fig. 2 Analysis of small RNAs retrieved in RNA samples extracted from cucumber leaves and phloem. A) A flowchart showing stepwise computational extraction of unique endogenous sRNAs recovered from leaves and phloem of infected and healthy plants. B) Graphic representation of the relative accumulation of the sequenced small RNAs fully homologous to ribosomal RNA.

A total of $4,343(4.91 \%)$ sequences recovered from infected cucumber leaves dataset (88,321 sequences) were perfectly complementary to HSVd and considered as vd-sRNAs (Fig. 3a and Table S1). Importantly, no HSVd fully homologous sequences were recovered from the healthy cucumber leaves confirming the integrity of the RNA samples. Viroid-derived sRNAs between 17 and 26 nts were recovered from our leaf library, although reads in the range of 20 to $24 \mathrm{nts}$ constituted $95.6 \%(4,154)$ of the total (Fig. 3a). These vd-sRNAs were mainly of 21 (53.1\%) and $22(21.6 \%)$ nts in size (Fig. 3 b), whereas vd-sRNAs of $24-$ nt corresponded to $15.1 \%$ of the total population. vdsRNAs species of $20-, 23-$ and $25-$ nts represented $6.85 \%$ of the reads. The residual fraction including vd-sRNAs of $<20 \mathrm{nts}$ or $>25 \mathrm{nts}$ in length $(\sim 3 \%)$ were discarded for further analysis. The sequenced pool of 20- to 25-nt vd-sRNAs encompassed 90,166 nts, which represented near 300 more nucleotides than the total genomic length (297 nt) of the HSVd used in this study. This observation suggested that our sequence set accurately reflects the entire vd-sRNAs population in the infected tissue and provides a comprehensive scenario to study vd-sRNA biogenesis. In addition, the strong bias in size distribution was consistent with the idea that viroid RNA might be targeted by distinct DCLs in a hierarchical fashion to produce different vd-sRNAs sizes, as described for plant- and virus-derived sRNAs (Ramachandran and Chen, 2008; RuizFerrer and Voinnet, 2009). 
A
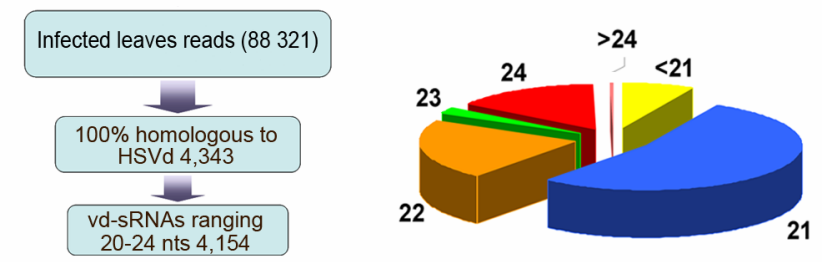

C

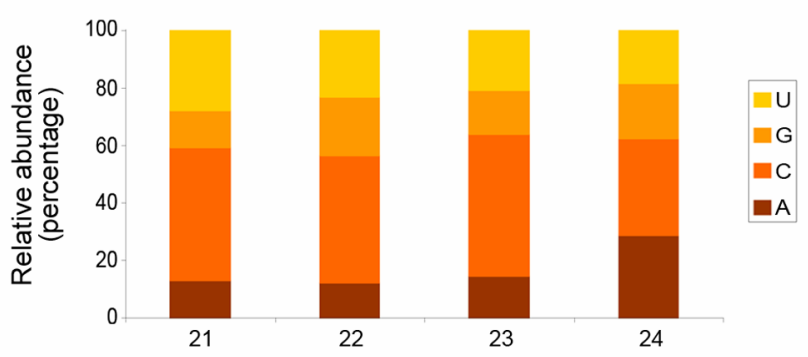

Fig. 3 Characterization of viroid derived small RNAs recovered from HSVd infected cucumber leaves by deep sequencing. A) A flowchart showing stepwise computational extraction of HSVd-derived sRNAs reads from our small RNAs library of infected cucumber leaves. B) Graphic representation of the size distribution of the sequenced viroid-derived sRNAs (vd-sRNAs). C) Histogram illustrating the relative abundance of the four different 5 '-terminal nucleotides in the most representative species of vd-sRNAs.

RNA silencing-associated sRNAs interacts with Argonaute (AGO)-containing RISC complexes to guide them to their target molecules. In the complex, sRNAs are responsible for target specificity whereas AGOs determine the RNA silencing effects (Kim, 2008; Ruiz-Ferrer and Voinnet, 2009). It has been recently reported that, in Arabidopsis, the selective loading of sRNAs into specific AGOs is influenced by their 5' terminal nucleotide (Mi et al., 2008; Montgomery et al., 2008; Takeda et al., 2008). Assuming that in cucumber plants, it exists the corresponding orthologous to the protein family ARGONAUTE (AGO), we analyzed the relative abundance of sequenced vd-sRNAs according to their $5^{\prime}$ terminal nucleotide (Fig. $3 \mathrm{c}$ ) in order to infer potential interactions with distinct AGO complexes. In contrast to the observed for diverse plant virus-specific sRNAs, that display a clear tendency to begin with $U$ or A (Donaire et al., 2009; Qi et al., 2009), vd-sRNAs with a C in the 5'-end were the most abundant $(\sim 45 \%)$, vd-sRNAs with a $5^{\prime}-U$ or A were similarly recovered $(\sim 22 \%$ and $20 \%$ respectively), while those with $5^{\prime}-\mathrm{G}$ were underrepresented $(\sim 11 \%)$ in the sequenced pool. These results suggested that vd-sRNAs could be potentially loaded into diverse AGO-containing silencing complexes in cucumber plants.

\section{ds-RNA plays a relevant role as one of the main precursors of vd-sRNAs}

To examine the genomic distribution of the vd-sRNA set, all sequences recovered from cucumber leaves were mapped along the HSVd genome. The 5'ends of 
the vd-sRNAs (21 to $24 \mathrm{nts}$ ) were plotted against the HSVd sequence according to their polarity and abundance (Fig. 4a and Supplementary Fig. 1). Several features were revealed from this analysis. First, the polarity distribution of the vd-sRNAs indicated that sense $(44.7 \%)$ and antisense $(55.2 \%)$ species were similarly represented in the sequenced pool, providing evidence that the vd-sRNAs were originated from both plus and minus HSVd RNA strands to a similar extent. Our results were in good agreement with the fact that sense and antisense polarities were also equally represented in a population of PSTVd-derived sRNAs (Machida et al., 2007). Interestingly, in a recent work addressed to characterize sRNAs from grape Carra et al. (2009) found that the sense and antisense polarities of the siRNAs recovered from the Grapevine yellow speckle viroid were equally represented. In contrast, previous findings obtained by lowscale sequencing of CEVd and PSTVd-derived sRNAs, showing that the amount of sense vd-sRNAs $(\sim 80 \%)$ was significantly higher than that of antisense vd-sRNAs ( 20\%) (Markarian et al., 2004; Martin et al., 2007). Second, sense and antisense vdsRNAs spread along the entire HSVd genome in an overlapping configuration, with virtually all nucleotide positions in the HSVd RNA being covered by vd-sRNAs in both polarities (Fig. 4a). Third, vd-sRNAs from both polarities displayed a heterogeneous distribution pattern along the HSVd sequence, as observed for most plant viruses (Qi et al., 2009; Donaire et al., 2009).

To gain further insights on vd-sRNA biogenesis, the sequence complexity of HSVd-derived sRNAs were analyzed for different size species. Unique vd-sRNAs from each of the most representative classes (21 to $24 \mathrm{nts}$ ) were individually plotted onto the HSVd genome and their sequence complexity was estimated as the number of unique vd-sRNA sequences that hit each of the single nucleotide position along the HSVd genome. Using a sliding window of 21 , maximum value of sequence complexity would be of 21 , which corresponded to the hypothetical formation of vd-sRNAs starting at any of the 21 nucleotide positions within the window. The highest sequence complexity was observed for the 21-nt size species followed by the 22- and 24-nt size class whereas the 23-nt size presented the lowest sequence complexity (Fig. 4b). 
A

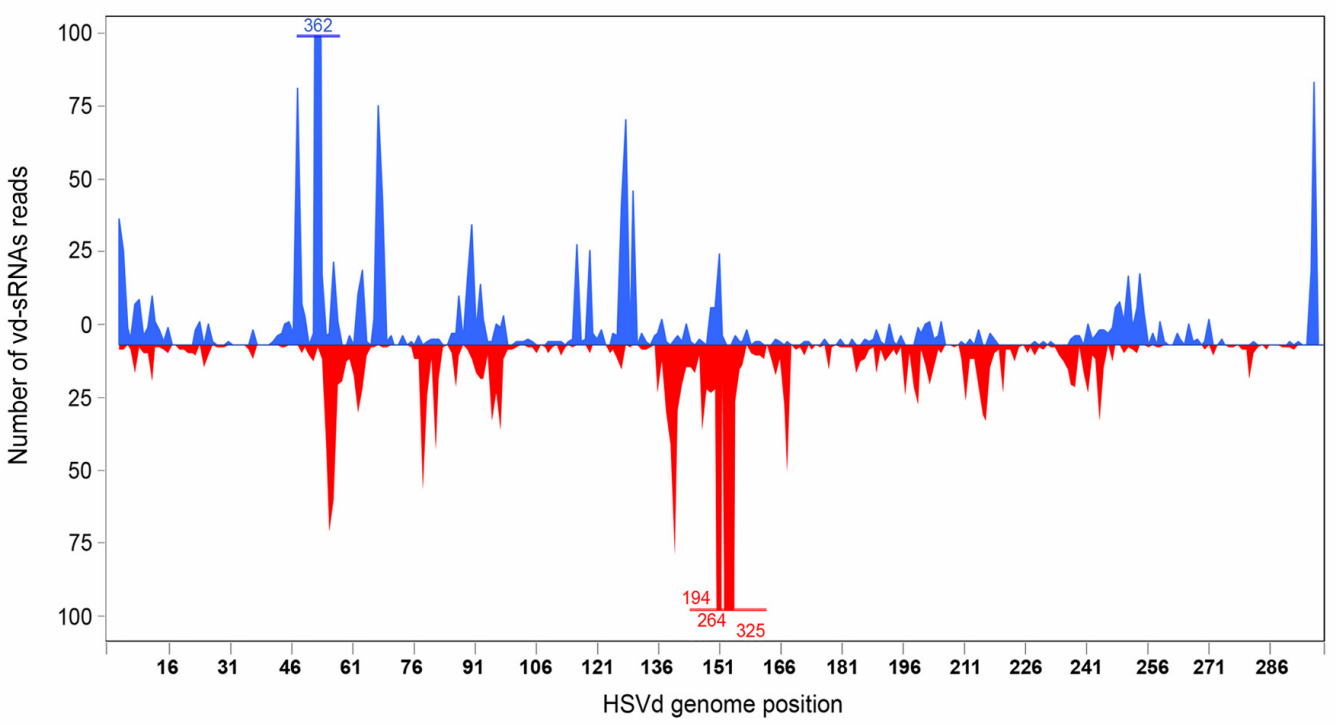

B
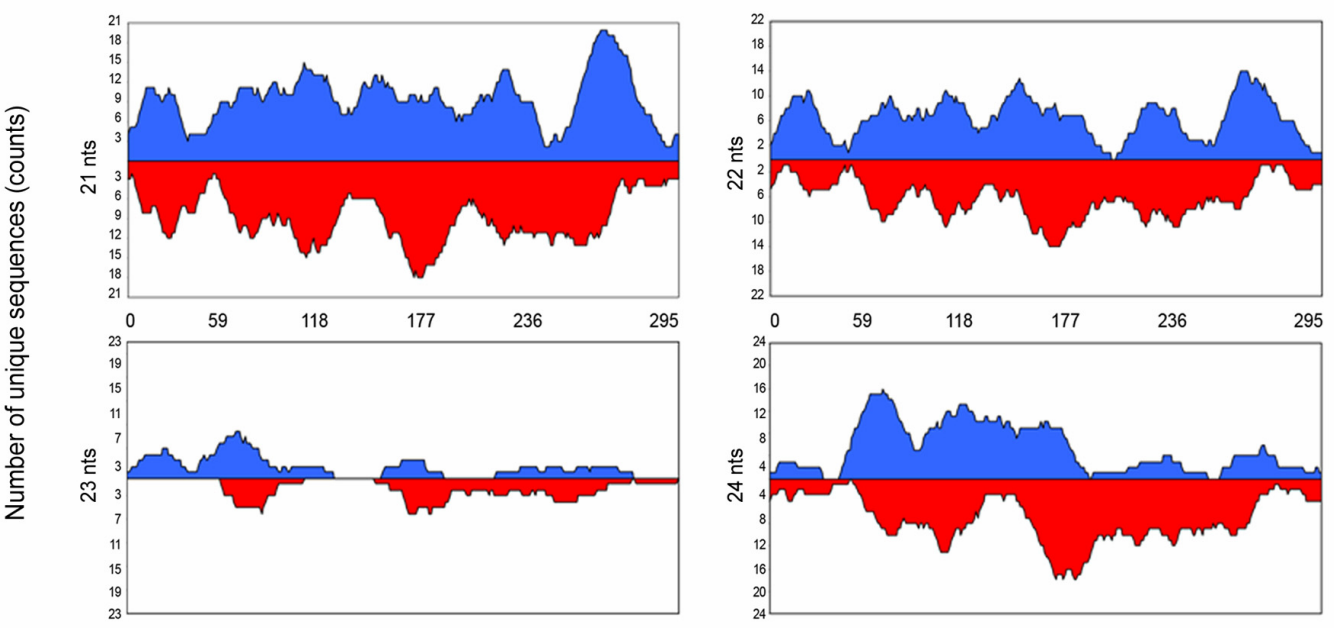

C

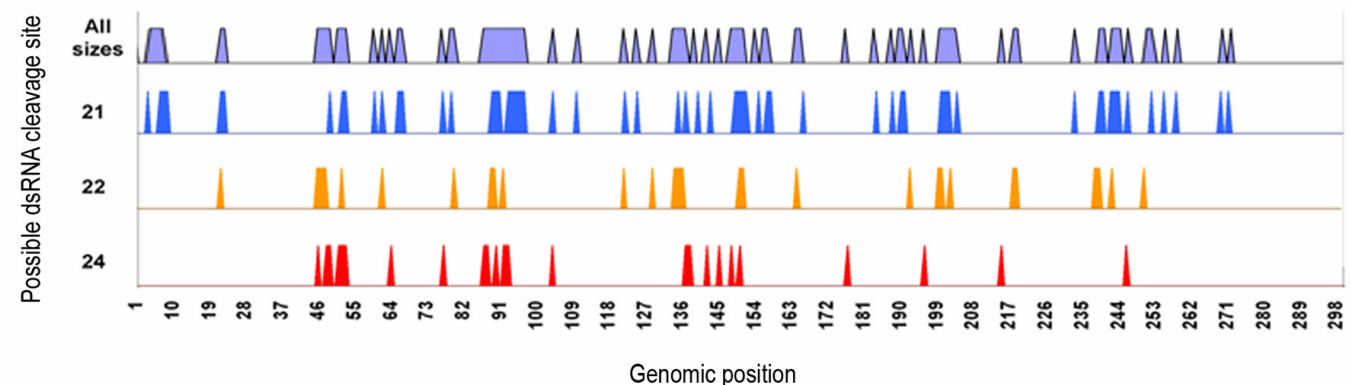

Fig. 4 A genome view of HSVd-derived sRNAs recovered from infected cucumber plants. A) The vd-sRNAs were plotted according the position of their 5 '-extrem onto the sequence of the HSVd-RNA used to infect cucumber plants (Y09352), in either sense (above the X-axis) or antisense (below the X-axis) configuration. The values in the $\mathrm{Y}$-axis represent the abundance of vd-sRNAs in the library. In the X-axis are represented the nucleotide positions 1 to 297 of the HSVd RNA. B) A high resolution view of HSVd-genome showing the number of plotted unique vdsRNAs, classified according size class $(21,22,23$ and 24-nt sizes). In the Y-axis are represented the times that a single HSVd nucleotide was present in a sense (above the X-axis) or antisense (below the X-axis) unique vd-sRNAs. C) The sense and antisense pairs of vd-sRNAs with perfect complementary strands, forming putative DCLs products generated from ds-RNAs substrates were mapped onto HSVd-genome according the size species. 
Interestingly, values near to the highest sequence complexity were found for both sense and antisense 21-nt vd-sRNAs in at least one genomic region. Our data indicated that the viroid genome was not uniformly targeted by the different components of the RNA silencing machinery involved in vd-sRNA biogenesis. Production of 21-nt vd-sRNA species was in general more efficient at any position of the viroid genome compared to that of 22- and 24-nt species. Furthermore, regions with higher sequence diversity for a given size class could be found throughout the HSVd genome. Finally, we tested if our data set contained pair(s) of perfectly complementary vd-sRNA with 2-nt overhangs at their 3' ends. Sense and antisense vd-sRNAs forming a duplex might be diagnostic of a DCL-mediated cleavage event on dsRNA substrates. We observed that a high frequency of sense 21- (54.7\%), 22- (47.0\%) and 24-nt (50.3\%) vd-sRNAs showed perfect complementarity with the antisense counterpart (Fig. 4c), suggesting that dsRNAs might be one of the main precursors for these highly represented vd-sRNAs.

\section{Phloem-derived vd-sRNA accumulated preferentially as 22-nt species}

In order to obtain a comprehensive picture of the vd-sRNAs species present in the phloem tissue, we analyzed independently the 39,026 sequences of sRNAs recovered from phloem sap of infected cucumber plants. A total of 1,278 (3.27\%) vdsRNAs perfectly complementary to HSVd were recovered from phloem exudates (herein refers to as Pvd-sRNAs) (Fig. 5a). Our data indicated that Pvd-sRNAs represented in the sequenced pool were of both sense $(54.2 \%)$ and antisense $(45.8 \%)$ orientation.

A striking feature of vd-sRNA derived from phloem exudates concerns their differential size distribution. While vd-sRNA from leaf tissue was predominately 21-nt long, Pvd-sRNA of 22 nts was the most representative size species (47\%) compared with the 21-nt size class (21.7\%) (Fig. 5b). A similar bias in size distribution was observed when unique 21- and 22-nt vd-sRNA species were analyzed (Fig. 5c). Although the 23- and 24-nt size species were poorly represented in both phloem and leaves libraries, a substantial increased of 23-nt vd-sRNAs and a decreased of 24-nt species was observed in phloem exudates when compared with vd-sRNAs from cucumber leaves (Fig. 5b). In conclusion, we observed a clear bias in the composition of vd-sRNAs from phloem with respect to that observed in infected cucumber leaves. Interestingly, an increase in the relative accumulation of 22-nt class in the phloem 
$(17.62 \%)$ compared to leaves (13.24\%) was observed for endogenous sRNAs in infected plants (Fig. 7a, right panel) whereas this ratio was inverted in healthy plants for which a decrease of the $\sim 50 \%$ in the relative accumulation of 22 -nt sRNAs in the phloem (15.07\%) compared to leaves (32.72\%) was observed (Fig. 7a, left panel).

A

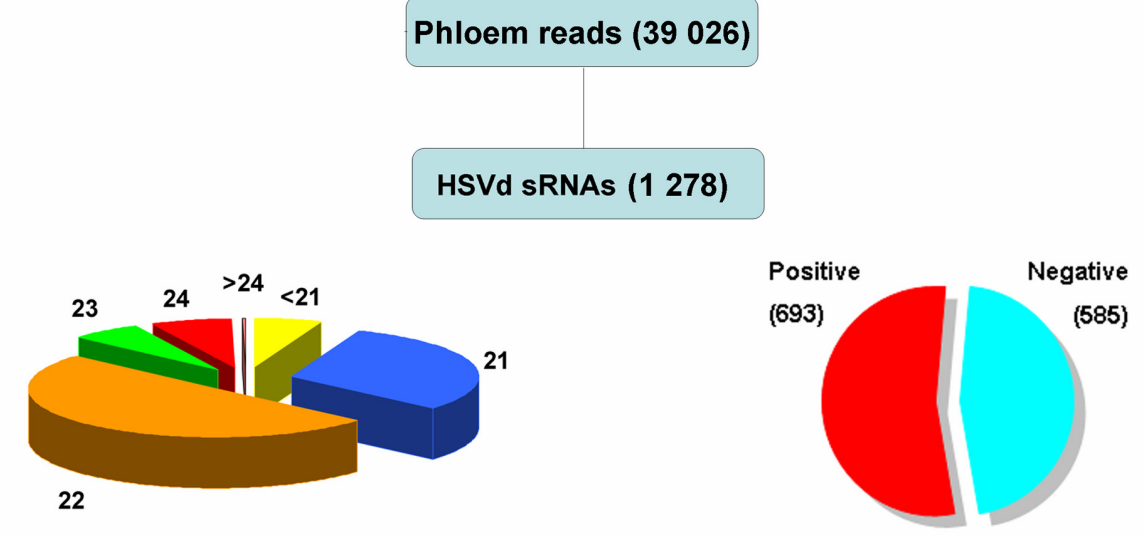

B

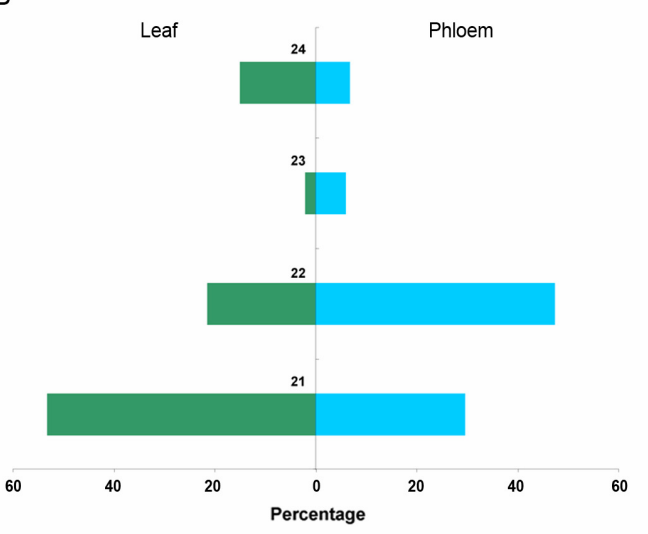

C

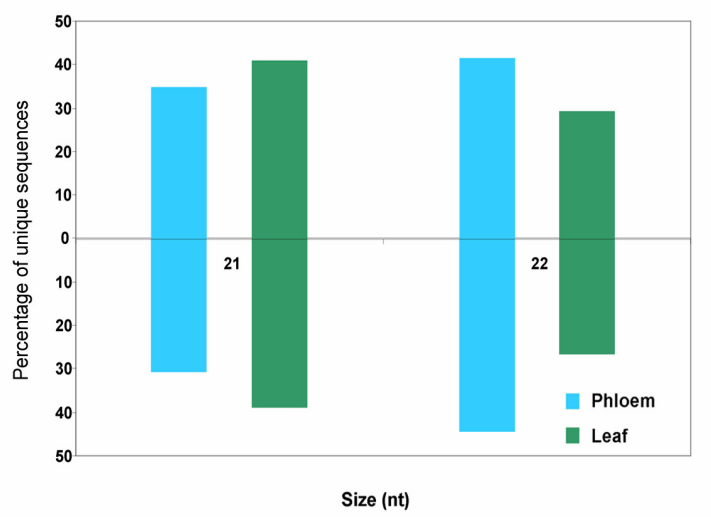

Fig. 5 Analysis of viroid derived small RNAs recovered from the phloem sap of infected cucumber plants. A) Size distribution of vd-sRNAs population detected in the phloem of infected cucumber plants. The proportional accumulation of sense and antisense vd-sRNAs is also illustrated. B) Relative abundance of the most representative size class of sense and antisense vd-sRNAs recovered from leaves (left) and phloem (right). C) Accumulation values in leaves and phloem of unique sense and antisense 21- and 22- nt vd-sRNAs.

\section{A consensus sequence is over-represented in the phloem vd-sRNAs}

Finally, we investigated the genomic distribution and origin of Pvd-sRNAs obtained from phloem exudates. The $5^{\prime}$ end of each Pvd-sRNA (21 to $24 \mathrm{nts}$ ) was plotted against the HSVd sequence according to their polarity and abundance (Fig. 6a and Supplementary Fig. 2). Although Pvd-sRNAs derived from all regions along the HSVd genome in both orientations, a high proportion of Pvd-sRNAs (34.1\%) was restricted around two well-differentiated hot-spots designated as phloem hot-spot 1 (phs-1) and 2 (phs-2) (Fig. 6a and Supplementary Fig. 2). The 5' termini of the 297 (23.3\% of phloem library) Pvd-sRNA reads clustering in phs-1 localized between 
positions 197 and 207 of the HSVd RNA. The phs-2, which encompassed 138 PvdsRNA reads (10.8\% of library), was restricted to position 251 to 255 . Interestingly, as illustrated in Figure 7b, high-resolution mapping revealed that the phs- 1 and 2 did not correlate with any of the remaining vd-sRNA hot spots observed in the dataset obtained from leaves. Furthermore, the phs-1 and 2 co-localized in the HSVd genome with regions of high sequence complexity estimated from unique Pvd-sRNAs (Supplementary Fig. 3), which argued against the possibility that the observed differences could be due to over-representation of specific Pvd-sRNA sequences owing to a bias in the sequencing procedure. Together, our data analysis including size and genome distribution suggested that the population of vd-sRNAs recovered from the phloem is substantially different to that observed in the infected cucumber leaves.

A

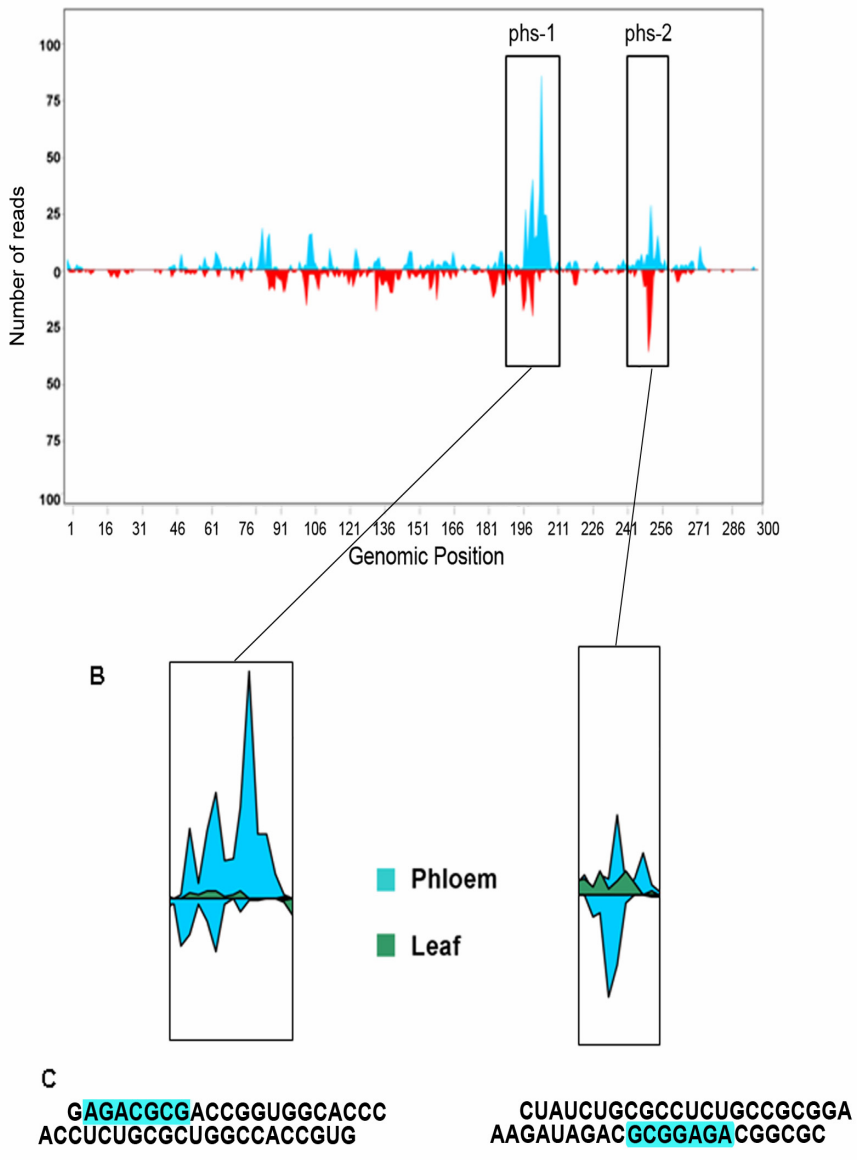

Fig. 6 Sequence analysis of the HSVdderives sRNAs highly accumulated in the phloem tissue. A) The vd-sRNAs recovered from phloem of infected cucumber plants were plotted according the position of their $5^{\prime}$-extrem onto the HSVd-RNA, in either sense (above the Xaxis) or antisense (below the $\mathrm{X}$-axis) configuration. B) High resolution genome view of the vd-sRNAs accumulating hotspot observed in the phloem sRNAs. The maps of the vd-sRNAs recovered from leaves and phloem were overlapped to analyze the relative abundance of each sRNA in the different tissues. C) Two representative Pvd-sRNAs clustering in the hot-spot 1 and 2 respectively were identified and aligned according their sequence. The common sequence signature AGAnGCG conserved in the highly accumulated Pvd-sRNAs is boxed. The Pvd-sRNAs are illustrated according the sequence of the plus strand HSVd-RNA.

A detailed analysis of the sequence composition within the subset of PvdsRNAs from phs- 1 and -2 revealed a common AGAnGCG sequence signature that was not observed for Pvd-sRNAs derived from other regions of the HSVd genome (Fig. 6c 
and Supplementary Fig. 4). This sequence was not exclusive for 22-nt species as the two highest 21-nt vd-sRNAs represented $(\sim 50 \%)$ in the phloem data set contained a AGAnGCG signature (Supplementary Fig. 3). This common sequence signature was also overrepresented in the non viroid-related sRNAs recovered from the infected phloem $(1.87 \%)$ compared to the endogenous sRNAs recovered from the leaves $(0.81 \%)$, (Fig. $7 b)$. These findings suggested the existence, in infected cucumber plants, of a selective predisposition to accumulate in the phloem sRNAs, preferentially 22-nt long, carrying this consensus sequence.
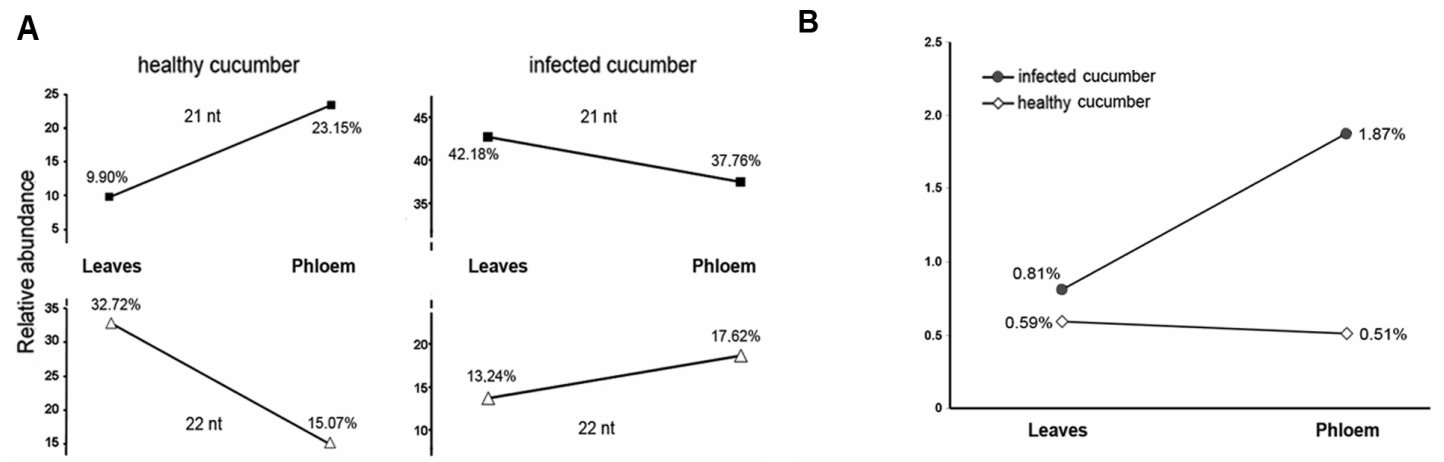

Fig. 7 Comparative analysis of the cucumber endogenous sRNAs accumulated in the leaves and phloem of healthy and infected plants. A pool of sRNAs enriched from total RNA preparations were extracted from phloem of healthy cucumber plants, processed and subjected to multiplexed pyrosequencing, as explained in the material and methods section. A total of 1,783 unique high quality sequences each containing endogenous sRNAs were obtained. A) Graphic shows a comparative analysis of the relative abundance of the two most representative size classes (21 and 22-nts) of endogenous sRNAs recovered from leaves and phloem in healthy (left panel and infected (right panel) cucumber plants. B) Graphic shows a comparative analysis of the relative abundance of the endogenous sRNAs carrying the sequence signature AGAnGCG recovered from leaves and phloem of healthy and infected plants.

\section{DISCUSSION}

Infection by members of the Pospiviroidae family is associated to the presence of vd-sRNAs (e.g. Itaya et al., 2001; Papaefthimiou et al., 2001). However, the mechanisms potentially involved in the biogenesis of vd-sRNAs are still a matter of speculation. Previously it was proposed that dsRNA viroid replication intermediates (Denti et al., 2004; Wang et al., 2004) and/or highly structured regions present in the viroid mature forms (Markarian et al., 2004; Itaya et al., 2007; Martin et al., 2007; StPierre et al., 2009) could serve as potential DCL substrates for the biosynthesis of vdsRNAs. Nevertheless, whether the biogenesis of vd-sRNAs is a DCL-dependent process remains to be experimentally demonstrated. Taking into account these previous data, alternative mechanisms of sRNA biosynthesis such as unprimed RNA synthesis 
directed by RDR activity, as described in Caenorhabditis elegans (Pak and Fire, 2007; Sijen et al., 2007) cannot be excluded.

In this paper, we used deep-sequencing to obtain an exhaustive picture of the viroid-specific sRNAs diversity and abundance in infected tissue. Our sequence analysis represented a high-resolution map for vd-sRNAs derived from a nuclear viroid (HSVd), providing an essential tool to understand the RNA silencing biogenesis pathways involved in their generation.

The profiling of the sequenced vd-sRNAs from infected cucumber plants indicated that the majority of vd-sRNAs could be classified as 21-, 22- and 24-nt size classes, which coincided with the three major classes predicted by the coordinated hierarchical action of DCL4, DCL2 and DCL3 (Bouche et al., 2006; Deleris et al., 2006). The presence of $5^{\prime}$ monophosphate ends in vd-sRNAs, inferred from the initial ligation with T4 RNA ligase, suggest that the majority of the sRNAs reads in our sequenced pool are true DCL products. In addition, the ubiquitous distribution of sense and antisense vd-sRNA species and their similar ratio observed in our libraries can be easily envisioned as a consequence of DCL (or ortologous protein presents in cucumber plants) processing of perfectly complementary viroid-derived dsRNAs. Multiple sense/antisense pairs with 3' overhangs were identified among the sequences in our HSVd dataset suggesting that they corresponded to the complementary strands originating from single DCL-mediated processing events.

Our results about the polarity distribution are in apparent contradiction with previous works reporting a predominant accumulation of sense vd-sRNAs in tomato plants infected with members of the Pospiviroidae family (Itaya et al., 2007; Martin et al., 2007). We believe that this difference is likely due to the relative low number of vdsRNA sequences analyzed in those studies. However, the possibility that differences in polarity distribution could be a consequence of functional differences between the uncharacterized tomato and cucumber RNA silencing mechanisms can not be excluded.

These results together indicate that the entire viroid genome was targeted by the RNA silencing machinery to produce vd-sRNAs, and suggested a model whereby vdsRNAs of both polarities might be mostly produced through DCL-mediated processing of long, viroid-derived dsRNA. This argues therefore against, but not excludes, a model by which local secondary structures within the positive-strand HSVd RNA were the principal precursors of vd-sRNA biosynthesis (Itaya et al., 2007; Martin et al., 2007). The wide spectrum of different vd-sRNAs suggest that the process by which these 
small RNAs are generated is more complex than previously thought, probably involving different biogenesis pathways and sub cellular compartments.

Viroid-derived sRNAs recovered in our libraries showed a strong bias for sequences beginning with a 5'-Cytosine, indicative of sRNAs with high binding affinity for AGO5 in Arabidopsis (Mi et al., 2008; Takeda et al., 2008). The role of AGO5 in RNA silencing remains unclear and their activity in plant defence has never been established (Brodersen and Voinnet, 2006; Chapman and Carrington, 2007; Ruiz-Ferrer and Voinnet, 2009). The potential preference of vd-sRNAs for an AGO without a demonstrated antiviral role is consistent with the recently suggested model by which the loading of vd-sRNAs to AGOs with little or no intrinsic activity in defence mechanism could contribute to prevent the RISC-mediated degradation of the viroid mature forms (Ruiz-Ferrer and Voinnet, 2009). This mechanism, in conjunction with the apparent resistance of structured viroid genomes to RISC activity (Itaya et al., 2007; Gomez and Pallas, 2007), could explain how the viroid mature forms can overcome the RNA silencing-mediated degradation in infected plants.

In plants, RNA silencing spreads systemically to distant tissues traveling through sieves elements following a source to sink pattern (Palauqui et al., 1997; Voinnet et al., 1998 ). Although it is commonly accepted that it should be an RNA molecule (Jorgensen, 2002), the identity of the phloem-transported signal and the mechanism whereby the signal is translocated are currently unknown (Dunoyer and Voinnet, 2008; Kalantidis et al., 2008). To provide a more comprehensive picture of the sRNAs that occur in the plant tissue responsible for long distance communication, we perform a detailed analysis of the vd-sRNAs recovered from the phloem of infected cucumber plants. Unlike that observed in leaves, the phloem sap of infected cucumber appears to contain a preponderant accumulation of 22-nt vd-sRNAs. This divergence in the general profile of the "phloem“ Pvd-sRNAs is more relevant considering that the 21$\mathrm{nt}$ size class is the highest represented species in infected leaves. As a result, the ratio of 21-/22-nts within the pool of vd-sRNAs was inverted from $1.8 / 1$ in leaves to $1 / 2.3$ in phloem. Until now, DCL activity has been not described within the phloem. If this activity would not exist in that tissue, it would be reasonable to assume that Pvd-sRNAs could be generated in the non-vascular tissues and subsequently transported to the sieve elements (Yoo et al., 2004). In consequence, the bias in the relative accumulation of the 22-nt class in phloem of infected plants could be considered as an indirect indicator of selective trafficking of 22- nt vd-sRNAs from their sites of biogenesis to the phloem. 
Interestingly, it was recently reported that 22-nt RNAs are able to direct systemic silencing of a GFP construct from transgenic stocks to wild-type scions in Arabidopsis plants (Brosnan et al., 2007). However, we can not exclude the possibility that this bias in the accumulation of the 22-nt class in the phloem could be due to a differential processing of the $22 \mathrm{nts}$ sRNAs in the companion cells of infected cucumber plants. Further studies providing a detailed analysis of relative accumulation of small RNAs in phloem and non phloem tissues of infected and healthy cucumber plants are required to elucidate this question.

High-resolution mapping of phloem-derived vd-sRNAs revealed a genome distribution that differed from the genome-wide spreading of vd-sRNA recovered from infected leaves. Vd-sRNAs from phloem exudates were mainly clustered in two welldefined regions that did not correlate with any of the conspicuous hot spots of vd-sRNA accumulation identified in the leaf dataset. Interestingly, the most highly represented Pvd-sRNAs possessed a common AGAnGCG sequence signature in the vd-sRNAs. It is therefore tempting to speculate that this sequence signature may favour the translocation of vd-sRNAs into the phloem, possibly by acting as a more efficient target for specific sRNA-binding proteins involved in the sRNAs trafficking from companion cell to sieve elements (Yoo et al., 2004).

In general, our results permit to envision a scenario in which the acummulation of vd-sRNAs in the phloem could be regulated at two different, but complementary levels: size and sequence, with vd-sRNAs of $22 \mathrm{nts}$ that contain the signature sequence being preferentially uploaded into the vascular tissue. Additional studies are necessary to establish the importance and the exact physiological role of this selective trafficking to the phloem and to elucidate if they can be also extended to plant endogenous and/or virus-derived small RNAs.

\section{EXPERIMENTAL PROCEDURES}

\section{Plant Material}

40 cucumber (Cucumis sativus Cv Suyo) plants were agroinoculated with Agrobacterium tumefaciens strain C58C1 transformed with a binary pMOG800 vector carrying a head-to-tail infectious dimeric HSVd cDNA (Y09352) (Gomez and Pallas, 2006) as previously described (Gomez et al., 2008). 10 non infected cucumber plants were used as negative control. Plants were maintained in environmentally controlled 
growing chambers at $30^{\circ} \mathrm{C}$ for $16 \mathrm{~h}$ with fluorescent light and at $25{ }^{\circ} \mathrm{C}$ for $8 \mathrm{~h}$ in darkness, and analyzed at 35 dpi.

\section{RNA isolation}

Pools of leaves ( $\sim 50 \mathrm{~g})$ obtained from different infected (40) and healthy (10) cucumber plants were used. Total RNA was extracted from this pool of infected and healthy cucumber leaves $(\sim 10 \mathrm{~g})$ using the TRI reagent (SIGMA, St. Louis, MO, USA) according to the manufacturer's instructions. Phloem RNA sampling from infected and healthy cucumber plants was performed as described earlier (Gomez and Pallas, 2004; Gomez et al., 2005). Phloem sap $(\sim 100 \mu \mathrm{l})$ was collected from groups of 2 (healthy) or 4 (infected) plants by multiples cuts in petioles or shoots apex directly on $1 \mathrm{ml}$ of TRI reagent (SIGMA, St. Louis, MO, USA) and processed according to the manufacturer's instructions. Pools of approximately $1 \mathrm{ml}$ of phloem sap obtained respectively from healthy and infected cucumber plants were used in this assay. The total RNAs preparations were quantified by spectrometry and their concentration was equalled.

\section{Northern blot assays}

Total RNA was electrophoresed under denaturing conditions in 5\% polyacrylamide gels with $0.25 \times$ TBE and $8 \mathrm{M}$ urea (Pallas et al., 1987). The RNA was blotted to nylon membranes (ROCHE Diagnostics GmbH, Mannheim, Germany), and hybridized as previously described (Gomez and Pallas, 2001). The low-molecular weight RNA ( $<200 \mathrm{nt}$ ) fraction was enriched using total RNA and MIRACLE (miRNA isolation Kit, STRATAGENE) according to the manufacturer's instructions. Approximately $25 \mu \mathrm{g}$ of LMW RNA was loaded onto $20 \%$ polyacrylamide gels with $0.25 \times \mathrm{TBE}$ and $8 \mathrm{M}$ urea. The RNA was transferred to a nylon membrane (ROCHE Diagnostics-GmbH, Mannheim, Germany). Hybridization was performed at $32.5^{\circ} \mathrm{C}$ for 14-16 h, using a Digoxigenin-labelled negative strand HSVd-RNA as a probe. The detection was performed as previously described (Gomez and Pallas, 2007).

\section{vd-RNAs amplification and sequencing}

Total RNAs $(\sim 300 \mu \mathrm{g})$ extracted from leaves and phloem exudates of HSVd infected cucumber plants were used for construction of sRNAs libraries as described (Kasschau et al., 2007) with the following minor modifications. The 3' adapter was $\begin{array}{llllll}\text { replaced } & \text { by } & \text { a } & \text { pre-activated } & \text { adenylated }\end{array}$ 
(5'rAppCTGTAGGCACCATCAAT3ddC 3') (Integrated DNA technologies) to avoid the circularization of sRNAs. The chimeric RNA/DNA oligonucleotide 5' adapters were described previously (Kasschau et al., 2007). A new adapter variant was generated by modification of the four-nucleotide identifier (3-1, ATCGTAGACGCCUGAUA). After each ligation step, sRNA was purified using 17\% denaturing PAGE. The purified-ligated sRNA was reverse transcribed and the cDNA was amplified using Taq DNA polymerase (Perkin Elmer) and 3' PCR FusionB and 5' PCR FusionA primers (Kasschau et al., 2007). PCR primers contained the "A" and "B" tag sequences used by 454 Life Science during sequencing. DNA amplicons were gelpurified using $12 \%$ native polyacrylamide and eluted in $0.3 \mathrm{M} \mathrm{NaCl}$ as described (Donaire et al., 2008). Quantity and quality of DNA amplicons were measured using ND-1000 spectrophotometer (Nanodrop) and Experion Automated Electrophoresis System (BIO-RAD), respectively. Same quantity of DNA amplicon from each library was pooled and sequenced by 454 Life Science technology (Lifesequencing, http://lifesequencing.com).

\section{Data mining of the sRNA pool and sequence analysis}

Library identification, adapters trimming, and cleaning of the reads, as well as library comparison, were performed by Perl scripts locally developed by the Bioinformatics Service at the IBMCP (http://www.ibmcp.upv.es). Eventual identification of HSVd specifics sRNAs, as well as their location in the viroid genome was done using a local installation of BLAST program. Data analysis was done using the STATGRAPHICS plus 5.1 software (http://www.statgraphics.com).

\section{Acknowledgments}

We thank Dr. J. Forment (Bioinformatics Service of the IBMCP) for his valuable contribution in the sequence analysis. This work was supported by grants BIO2008-03528 and BIO2006-13107 to V.P. and C.L., respectively, from the Spanish granting agency DGICYT and by grant GV05-238 from the Generalitat Valenciana to G.G. Martinez, G. and Donaire, L. are the recipients of a fellowship from the Ministry of Science and Innovation. Gomez, G. is the recipient of a contract from the CSIC. 


\section{REFERENCES}

1- Allen, E., Xie, Z., Gustafson, A.M. and Carrington, J.C. (2005) microRNA-directed phasing during trans-acting siRNA biogenesis in plants. Cell 121, 207-221.

2- Aung, K., Lin, S.I., Wu, C.C., Huang, Y. T., Su, C.I. and Chiou, T.J. (2006) pho2, a phosphate over accumulator, is caused by a nonsense mutation in a microRNA399 target gene. Plant Physiol. 141, 1000-1011.

3- Bari, R., Pant, B.D., Stitt, M. and Scheible, W.R. (2006) PHO2, microRNA399, and PHR1 define a phosphate-signaling pathway in plants. Plant Physiol. 141, 988-999.

4- Baulcombe, D. (2004) RNA silencing in plants. Nature 431, 356-363.

5- Bouche, N., Lauressergues, D., Gasciolli, V. and Vaucheret, H. (2006) An antagonistic function for Arabidopsis DCL2 in development and a new function for DCL4 in generating viral siRNAs. EMBO J. 25, 3347-3356.

6- Brodersen, P. and Voinnet, O. (2006) The diversity of RNA silencing pathways in plants. Trends Genet. 22, 268-280.

7- Brosnan, C.A., Mitter, N., Christie, M., Smith, N.A., Waterhouse, P.M. and Carrol, B.J. (2007) Nuclear gene silencing directs reception of long-distance mRNA silencing in Arabidopsis. Proc. Natl. Acad. Sci. USA. 104, 14741-14746.

8- Buhtz, A., Springer, F., Chappell, L., Baulcombe, D. and Kehr, J. (2008) Identification and characterization of small RNAs from the phloem of Brassica napus. Plant J. 53, 739-749.

9- Carbonell, A., Martínez de Alba, A.E., Flores, R. and Gago, S. (2008) Doublestranded RNA interferes in a sequence-specific manner with the infection of representative members of the two viroid families. Virology 371, 44-53.

10- Carra, A., Mica, E., Gambino, G., Pindo, M., Moser, C., Pè, M. and Schubert, A. (2009) Cloning and characterization of small non-coding RNAs from grape. Plant J. 59, 750-753

11- Chapman, E.J. and Carrington, J.C. (2007) Specialization and evolution of endogenous small RNA pathways. Nat. Rev. Genet. 8, 884-896.

12- Daròs, J.A., Elena, S.F. and Flores, R. (2006) Viroids: an Ariadne's thread into the 
RNA labyrinth. EMBO Rep. 7, 593-598.

13- Deleris, A., Gallego-Bartolome, J., Bao, J., Kasschau, K.D., Carrington, J.C. and Voinnet, O. (2006) Hierarchical action and inhibition of plant Dicer-like proteins in antiviral defense. Science 313, 68-71.

14- Denti, M.A., Boutla, A., Tsagris, M. and Tabler, M. (2004) Short interfering RNAs specific for Potato spindle tuber viroid are found in the cytoplasm but not in the nucleus. Plant J. 37, 762-769.

15- Ding, B. (2009) Biology of Viroid-Host interactions. Annu. Rev. Phytopathol. 47, 105-131.

16- Donaire, L., Barajas, D., Martinez-Garcia, B., Martinez-Priego, L., Pagan, I. and Llave, C. (2008). Structural and genetic requirements for the biogenesis of Tobacco rattle virus-derived small interfering RNAs. J. Virol. 82, 5167-5177.

17- Donaire, L., Wang, Y., Gonzalez-Ibeas, D., Mayer, K., Aranda, M. and Llave, C. (2009) Deep-sequencing of plant viral small RNAs reveals effective and widespread targeting of viral genomes. Virology 30, 203-214.

18- Dunoyer, P. and Voinnet, O. (2008) Mixing and matching: the essence of plant systemic silencing? Trends Genet. 24,151-154.

19- Fahlgren, N., Howell, M.D., Kasschau, K.D., Chapman, E.J., Sullivan, C.M., Givan, S.A., Kasschau, K.D. and Carrington, J.C. (2007) High-Throughput Sequencing of Arabidopsis microRNAs: Evidence for Frequent Birth and Death of MIRNA Genes. PLoS ONE 2, e219.

20- Flores, R., Hernández, C., Martínez de Alba, A.E., Daròs, J.A. and Di Serio, F. (2005) Viroids and viroid-host interactions. Ann. Rev. Phytopathol. 43, 117-139.

21- Gómez, G., Martinez, G. and Pallas, V. (2008) Viroid-induced symptoms in Nicotiana benthamiana plants are dependent of RDR6 activity. Plant Physiol. 148, 414423

22- Gómez, G., Martinez, G. and Pallás, V. (2009) Interplay between viroid-induced pathogenesis and RNA silencing pathways. Trends Plant Sci. 14, 264-269.

23- Gómez, G. and Pallás, V. (2001) Identification of an in vitro ribonucleoprotein complex between a viroid RNA and a phloem protein from cucumber plants. Mol. Plant-Microbe Interact. 14, 910-913. 
24- Gómez, G. and Pallás, V. (2004) A long-distance translocatable phloem protein from cucumber forms a ribonucleoprotein complex in vivo with Hop stunt viroid RNA. J. Virol. 78, 10104-10110.

25- Gómez, G. and Pallás, V. (2006) Hop stunt viroid is processed and translocated in transgenic N. benthamiana plants. Mol. Plant Pathol. 7, 511-517.

26- Gómez, G. and Pallás, V. (2007) Mature monomeric forms of Hop stunt viroid resist RNA silencing in transgenic plants. Plant J. 51, 1041-1049.

27- Gómez, G., Torres, H. and Pallás, V. (2005). Identification of translocatable RNAbinding phloem proteins from melon, potential components of the long-distance RNA transport system. Plant J. 41, 107-116.

28- Itaya, A., Folimonov, A., Matsuda, Y., Nelson, R.S. and Ding, B. (2001) Potato spindle tuber viroid as inducer of RNA silencing in infected tomato. Mol. PlantMicrobe Interact. 14, 1332-1334.

29- Itaya, A., Zhong, X., Bundschuh, R., Qi, Y., Wang, Y., Takeda, R., Harris, A.R., Molina, C., Nelson, R.S. and Ding, B. (2007) A structured viroid RNA Is substrate for Dicer-Like cleavage to produce biologically active small RNAs but is resistant to RISC-mediated degradation. J. Virol. 81, 2980-2994.

30- Jorgensen, R.A. (2002) RNA traffics information systemically in plants. Proc. Natl. Acad. Sci. USA. 99, 11561-11563.

31- Kalantidis, K., Schumacher, H.T., Alexiadis, T. and Helm, J.M. (2008) RNA silencing movement in plants. Biol. Cell 100, 13-26.

32- Kasschau, K.D., Fahlgren, N., Chapman, E.J., Sullivan, C.M., Cumbie, J.S., Givan, S.A. and Carrington, J.C. (2007) Genome-wide profiling and analysis of Arabidopsis siRNAs. PLoS Biol. 5, e57.

33- Kim, V.N. (2008) Sorting out small RNAs. Cell 133, 25-26.

34- Machida, S., Yanahata, N., Watanuki, H., Owens, R.A. and Sano, T. (2007) Successive accumulation of two size classes of viroid-specific small RNA in Potato spindle tuber viroid-infected tomato plants. J. Gen. Virol. 88, 3452-3457.

35- Markarian, N., Li, H.W., Ding, S.W. and Semancik, J.S. (2004) RNA silencing as related to viroid induced symptom expression. Arch. Virol. 149, 397-406. 
36- Martín, R., Arenas, C., Daròs, J.A., Covarrubias, A., Reyes, J.L. and Chua, N. (2007) Characterization of small RNAs derived from Citrus exocortis viroid in infected tomato plants. Virology 367, 135-146.

37- Martinez de Alba, A.E., Flores, R. and Hernandez, C. (2002) Two chloroplastic viroids induce the accumulation of the small RNAs associated with post-transcriptional gene silencing. J. Virol. 76, 13094-13096.

38- Matoušek, J., Kozlová, P., Orctová, L., Schmitz, A., Pesina, K., Bannach, O., Diermann, N., Steger, G. and Riesner, D. (2007) Accumulation of viroid-specific small RNAs and increase in nucleolytic activities linked to viroid-caused pathogenesis. Biol. Chem. 388, 1-13.

39- Mi S, Cai, T., Hu, Y., Chen, Y., Hodges, E., Ni, F., Wu, L., Li, S., Zhou, H., Long, C., Chen, S., Hannon, G.J. and Qi, Y. (2008) Sorting of small RNAs into Arabidopsis argonaute complexes is directed by the $5^{\prime}$ terminal nucleotide. Cell 133, 116-127.

40- Montgomery, T.A., Howell, M.D., Cuperus, J.T., Li, D., Hansen, J.E., Alexander, A.L., Chapman, E.J., Fahlgren, N., Allen, E. and Carrington, J.C. (2008) Specificity of ARGONAUTE7-miR390 interaction and dual functionality in TAS3 trans-acting siRNA formation. Cell 133, 128-141.

41- Pak, J. and Fire, A. (2007) Distinct populations of primary and secondary effectors during RNAi in C. elegans. Science 315, 241-244.

42- Palauqui, J.C., Elmayan, T., Pollien, J.M. and Vaucheret, H. (1997) Systemic acquired silencing: transgene-specific post-transcriptional silencing is transmitted by grafting from silenced stocks to non-silenced scions. EMBO J. 16, 4738-4745.

43- Pallás, V., Navarro, A. and Flores, R. (1987) Isolation of a viroid-like RNA from Hop different to Hop stunt viroid. J. Gen. Virol. 68, 3201-3205.

44- Papaefthimiou, I., Hamilton, A.J., Denti, M.A., Baulcombe, D.C., Tsagris, M. and Tabler, M. (2001) Replicating Potato spindle tuber viroid RNA is accompanied by short RNA fragments that are characteristic of post-transcriptional gene silencing. Nucl. Acids Res. 29, 2395-2400.

45- Qi, X., Bao, F.S. and Xie, Z. (2009) Small RNA deep sequencing reveals role for Arabidopsis thaliana RNA-dependent RNA polymerases in viral siRNA biogenesis. PLoS ONE. 4(3), e4971. 
46- Rajagopalan, R., Vaucheret, H., Trejo, J. and Bartel, D.P. (2006) A diverse and evolutionarily fluid set of microRNAs in Arabidopsis thaliana. Genes Dev. 20, 34073425 .

47- Ramachandran, V. and Chen, X. (2008) Small RNA metabolism in Arabidopsis. Trends Plant Sci. 13, 368-374.

48- Ruiz-Ferrer, V. and Voinnet, O. (2009) Roles of plant small RNAs in biotic stress responses. Annu. Rev. Plant Biol. 60, 485-510.

49- Schiebel, W., Pélissier, T., Riedel, L., Thalmeir, S., Schiebel, R., Kempe, D., Lottspeich, F., Sänger, H.L. and Wassenegger, M. (1998) Isolation of an RNA-directed RNA polymerase-specific cDNA clone from tomato. Plant Cell 10, 2087-2101.

50- Sijen, T., Steiner, F.A., Thijssen, K.L. and Plasterk, R.H. (2007) Secondary siRNAs result from unprimed RNA synthesis and form a distinct class. Science 315, 244-247.

51- St-Pierre, P., Hassen, F.I., Thompson, D. and Perreault, J.P. (2009) Characterization of the siRNAs associated with peach latent mosaic viroid infection. Virology 383, 178182.

52 Takeda, A., Iwasaki, S., Watanabe, T., Utsumi, M. and Watanabe, Y. (2008) The mechanism selecting the guide strand from small RNA duplexes is different among argonaute proteins. Plant Cell Physiol. 49, 493-500.

53- Tsagris, M., Martinez de Alba, A.E., Gozmanova, M. and Kalantidis, K. (2008) Viroids. Cell Microbiol. 10, 2168-2179.

54- Válóczi, A., Várallyay, E., Kauppinen, S., Burgyán, J. and Havelda, Z. (2006) Spatio-temporal accumulation of microRNAs is highly coordinated in developing plant tissues. Plant J. 47,140-151.

55- Vaucheret, H. (2006) Post-transcriptional small RNA pathways in plants: mechanisms and regulations. Genes Dev. 20, 759-771.

56- Vogt, U., Pelissier, T., Putz, A., Razvi, F., Fischer, R. and Wassenneger, M. (2004) Viroid-induced RNA silencing of GFP-viroid fusion transgenes does not induce extensive spreading of methylation or transitive silencing. Plant J. 38, 107-118.

57- Voinnet, O. (2008) Use, tolerance and avoidance of amplified RNA silencing by plants. Trends Plant Sci. 13, 317-28. 
58- Voinnet, O., Vain, P., Angel, S. and Baulcombe, D. (1998) Systemic spread of sequence specific transgene RNA degradation in plants is initiated by localized introduction of ectopic promotorless DNA. Cell 95, 177-187.

59- Wang, M.B., Bian, X.Y., Wu, L.M., Liu, L.X., Smith, N.A., Isenegger, D., Wu, R.M., Masuta, C., Vance, V.B., Watson, J.M., Rezaian, A.,. Dennis, E.S and Waterhouse, P.M. (2004) On the role of RNA silencing in the pathogenicity and evolution of viroids and viral satellites. Proc. Natl. Acad. Sci. USA. 101, 3275-3280.

60- Wassenegger, M. and Krczal, G. (2006) Nomenclature and functions of RNAdirected RNA polymerases. Trends Plant Sci. 11, 142-151.

61- Xie, Z., Johansen, L.K., Gustafson, A.M., Kasschau, K.D., Lellis, A.D., Zilberman, D., Jacobsen, S.E. and Carrington, J.C. (2004) Genetic and functional diversification of small RNA pathways in plants. PLoS Biol. 2, e104.

62- Yoo, B.C., Kragler, F., Varkonyi-Gasic, E., Haywood, V., Archer-Evans, S., Lee, Y.M., Lough, T.J. and Lucas, W.J. (2004) A systemic small RNA signaling system in plants. Plant Cell 16, 1979-2000. 


\section{SUPPLEMENTARY MATERIAL}

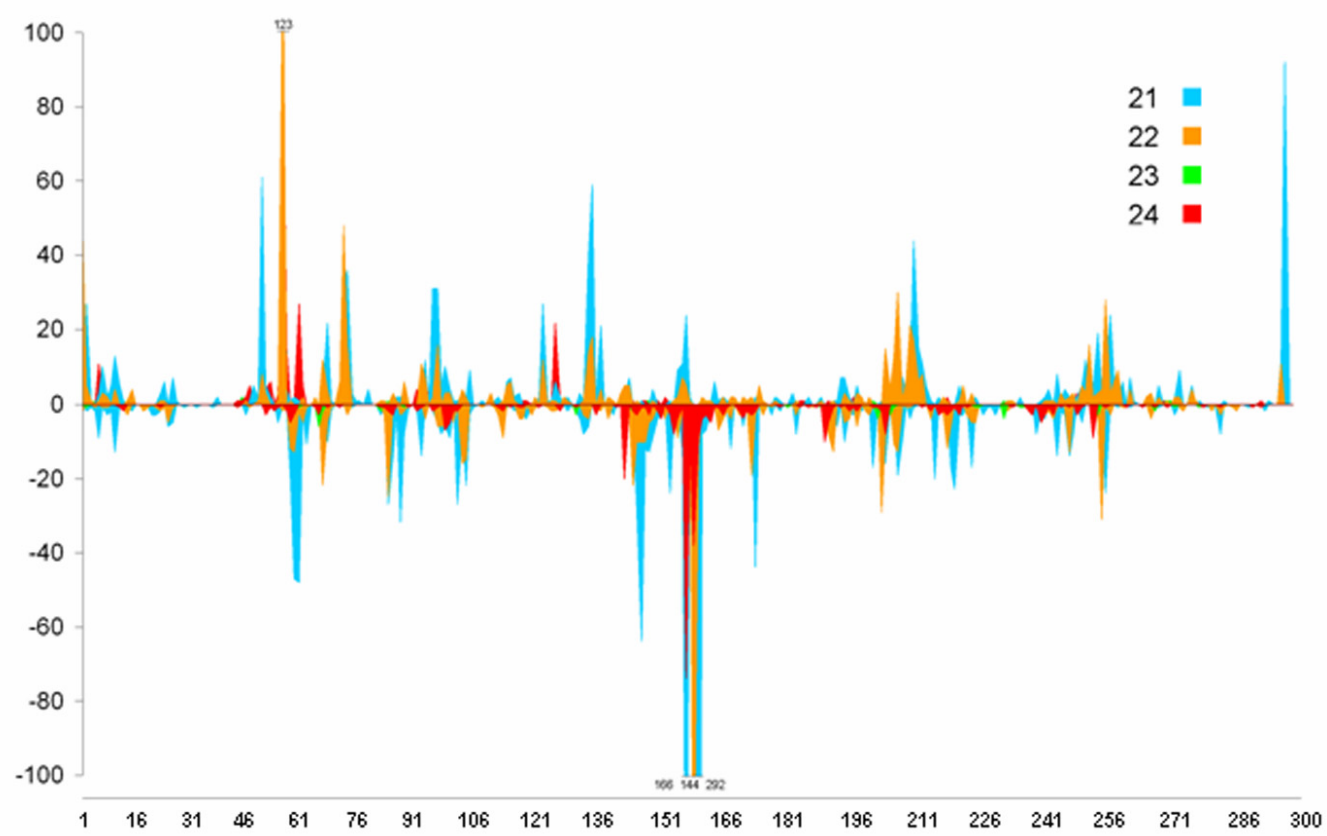

Figure supplementary 1: The most represented vd-sRNAs species (21- to 24- nt) recovered from infected cucumber plants were plotted individually according the position of their 5 '-extrem onto the HSVd-RNA, in either sense (above the $\mathrm{X}$-axis) or antisense (below the $\mathrm{X}$-axis) configuration. The values in the $\mathrm{Y}$-axis represent the abundance of vdsRNAs in the library. In the X-axis are represented the nucleotide positions 1 to 297 of the HSVd.
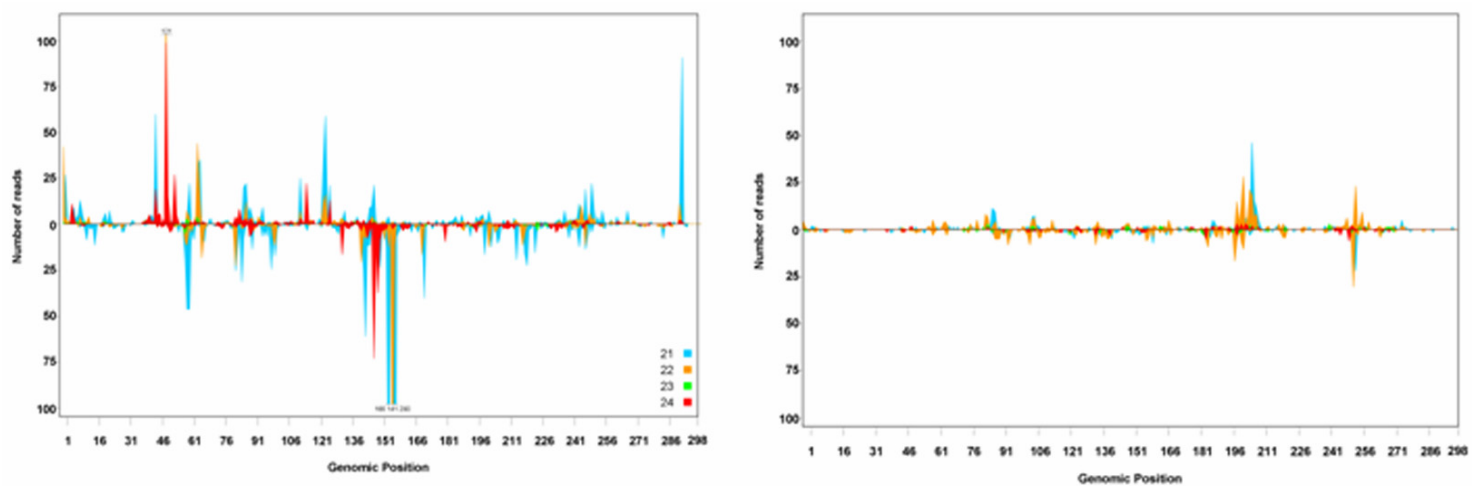

Figure supplementary 2: The sense and antisense vd-sRNAs specifically recovered from leaves (left panel) and phloem exudate (right panel) of infected cucumber plants were classified according their size class and plotted separately onto HSVd-genome. Graphic contents are as described in the figure 3. 
A
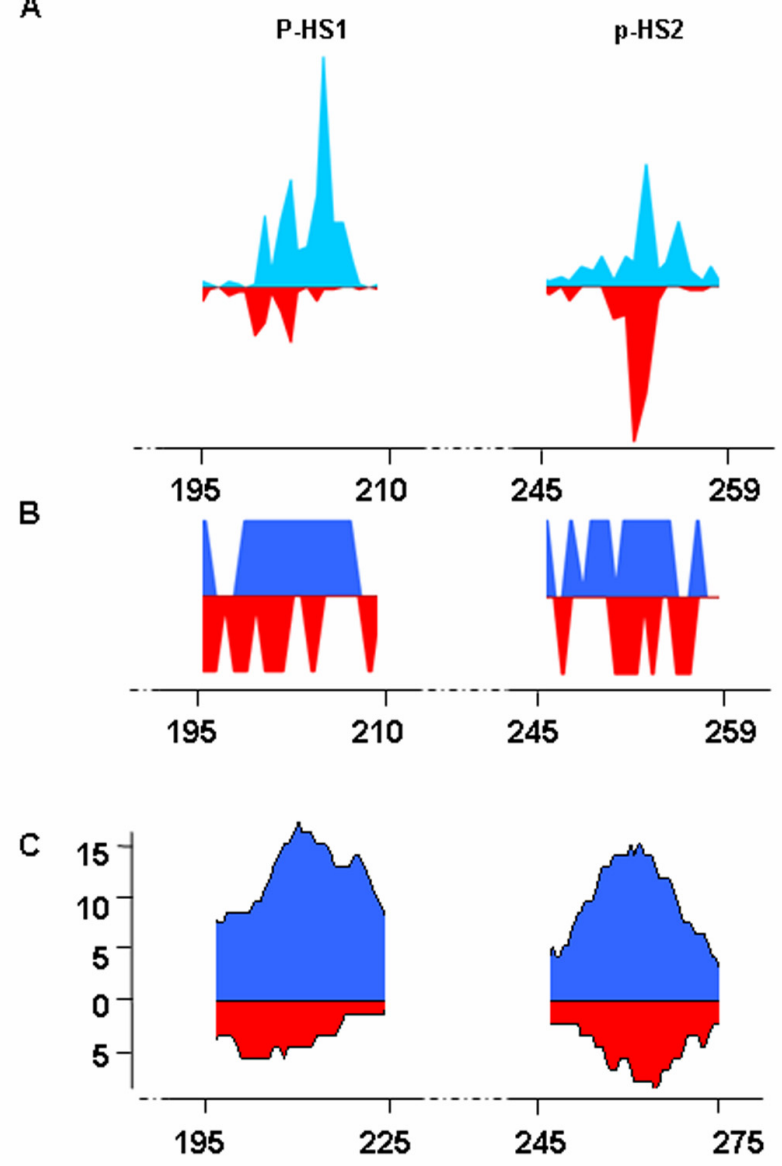

Phloem hot spot 1

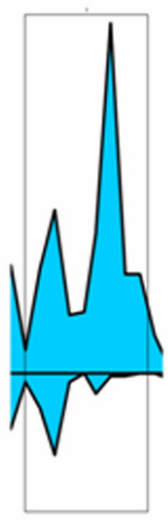

UCUUCUUGGAGACGCGACCGG CGAGAAGAACQUCUGCGOUGG CUCUCUUCUUGGAGACGCGACC GAGAAGAACCUCUGCGCUGGCC GAGAAGAACCUCUGCGCUGGCC UUCUUGGAGACGCGACCGGUG GAAGAACCUCUGCGCUGGCC UCUUGGAGACGCGACCGGUGG GAAGAACOUCUGCGDUGGCCA CUUGGAGACGCGACCGGUGGC AACAACCUCUGCGCUGGCCAC
Phloem hot spot 2

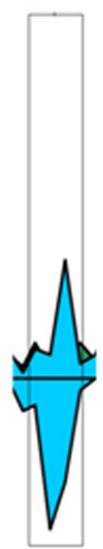

UUUUGUUCUAUCUGCGCCUCUGC UUUUGUUCUAUCUGCGCCUCUGC
CGAAAACAAGAUAGACGCGGAGA UUUGUUCUAUCUGCGCCUCUGC GAAAACAAGAUAGUCGCGGA UUU UUGUUCUAUCUGCGCCUCUGCC AAACAAGAUAGACGCGGAGAC UGUUCUAUCUGCGCCUCUGC AACAAGAUAGACGCGGAGA UGUUCUAUCUGCGCCUCUGCCG AAACAAGAUAGACGCGGAGACG
Figure supplementary 3:

Analysis of the most represented phloem 22- nt vd-sRNAs. A) High resolution viewing of the vd-sRNAs clustering in the sRNAs- accumulating hotspot 1 and 2 (showed above). B) Sense and antisense unique 22- nt vdsRNAs were plotted onto the HSVd genome. C) Sequence complexity of the 22- nt vd-sRNAs in hotspots surrounding regions. The values of sequence complexity were obtained as is explained in the text.
Figure supplementary 4: Identification of the specific signature sequence in the phloem vd-sRNAs. The vd-sRNAs clustering in the sRNAsaccumulating hot-spot 1 and 2 were identified and aligned according their sequence. The common sequence signature AGAnGCG conserved in the highly accumulated phloem vdsRNAs is boxed. The PvdsRNAs are illustrated according the sequence of the plus strand HSVd-RNA. Pvd-sRNAs in black corresponded to the sequenced strand; the vd-sRNAs in grey represent their predicted complementary strand. 
Capitulo IV 


\title{
High-throughput sequencing, characterization and detection of novel and conserved cucumber miRNAs
}

\author{
Martínez $\mathbf{G}^{\mathbf{1}}$, Forment $\mathbf{J}^{\mathbf{1}}$, Llave $\mathbf{C}^{\mathbf{2}}$, Pallás $\mathbf{V}^{\mathbf{1}}$ and $\mathbf{G o ́ m e z} \mathbf{G}^{\mathbf{1}}$. \\ 1. Instituto de Biología Molecular y Celular de Plantas, Consejo Superior de \\ Investigaciones Científicas-UPV, CPI, Edificio $8 \mathrm{E}$, Av. de los Naranjos s/n, \\ 46022 Valencia, Spain \\ 2. Centro de Investigaciones Biológicas, Consejo Superior de Investigaciones \\ Científicas, Ramiro de Maeztu 9, 28040 Madrid, Spain
}

Plos One 6(5):e19523 doi:10.1371/journal.pone.0019523 (2011)

\begin{abstract}
Micro RNAS (miRNAs) are a class of endogenous small non coding RNAs involved in the post-transcriptional regulation of gene expression. In plants, a great number of conserved and specific miRNAs, mainly arising from model species, have been identified to date. However less is known about the diversity of these regulatory RNAs in vegetal species with agricultural and/or horticultural importance.

Here we report a combined approach of bioinformatics prediction, highthroughput sequencing data and molecular methods to analyze miRNAs populations in cucumber (Cucumis sativus) plants. A set of 19 conserved and 6 known but non-conserved miRNA families were found in our cucumber small RNA dataset. We also identified 7 (3 with their miRNA* strand) not previously described miRNAs, candidates to be cucumber-specific. To validate their description these new $C$. sativus miRNAs were detected by northern blot hybridization. Additionally, potential targets for most conserved and new miRNAs were identified in cucumber genome.

In summary, in this study we have identified, by first time, conserved, known non-conserved and new miRNAs arising from an agronomically important species such as $C$. sativus. The detection of this complex population of regulatory small RNAs suggests that similarly to that observe in other plant species, cucumber miRNAs may possibly play an important role in diverse biological and metabolic processes.
\end{abstract}




\section{INTRODUCTION}

The discovery of MicroRNAs (miRNAs) is a milestone in the development of modern biology. MiRNAs are a class of endogenous $\sim 21$ nucleotide (nt) small noncoding RNA (sncRNA) presents in both plants and animals. In plants, mature miRNAs are processed by the DICER-LIKE 1 (DCL1) RNase III-like protein from a longer nuclear-localized RNA transcript that forms a fold-back stem-loop structure of partially complementary double-stranded RNA (dsRNA). miRNAs regulate gene expression in a sequence-specific manner via degradation of target mRNAs or inhibition of protein translation $[1,2]$. Increasing evidence indicates that miRNAs, together with other noncoding RNA families, play major roles in plant development and response to biotic and abiotic stress [3]. Initially, miRNAs were identified by conventional low-scale sequencing of cDNA clones from small RNA libraries prepared from different plant sources.

Subsequent studies showed that a significant subset of plant miRNAs are strictly conserved across different species within the plant kingdom [4]. Alternatively it was also reported that a smaller proportion of miRNAs, often expressed at low levels, were absents in diverse species suggesting that they could have evolved more recently [5]. As a result, non-conserved miRNAs that are rarely retrieved from low-scale sequencing experiments remain poorly characterized in most plant species. However, the recent irruption of high-throughput sequencing technologies has allowed deeper sampling of the small RNA populations enabling the identification of a substantial number of nonconserved miRNAs in diverse vegetal-species [6-11].

At least, two criteria involving expression and biogenesis parameters have been adopted for miRNA annotation $[12,13]$. A primary criterion establishes that candidate miRNAs should be supported by in vivo detection or cloning of the $\sim 21$-nucleotide miRNA/miRNA* duplex that arise from the stem of a single-stranded, stem-loop precursor [13]. Second, the satisfaction of one or more of the follow ancillary criteria can increase the confidence of a miRNA annotation: (i) the fold-back structure should be phylogenetically conserved; (ii) the precursor should be shown to accumulate in organisms with impaired Dicer function; and (iii) the expression of the predicted miRNAs should be validated by Northern blot hybridization and/or PCR amplification [12]. Inspired in these annotation criteria, to date, more than 2,500 conserved and 
recently evolved species-specific miRNAs have been deposited in the miRNA Registry Database (miRBase Release 16.0, September 2010; http://microrna.sanger.ac.uk/).

Cucumber (Cucumis sativus L.) is among the 20 most important vegetable crops worldwide (http://faostat.fao.org), and it has been proposed as a model plant for vascular and sexual development studies $[14,15]$. However, despite of its agronomic and biological importance and the recent publication of their complete genome [16], miRNAs in cucumber have not been reported yet. To take advantage of the recently published sequence data of endogenous small-RNAs recovered from cucumber [17], here we combined bioinformatics with high-throughput sequencing data to provide the first inventory of cucumber miRNAs population. We identified 25 previously described plant-miRNA families as well as 7 additional unknown miRNAs. The accumulation of a representative set of conserved and new cucumber miRNAs was experimentally validated by northern blot assays, using non-isotopic miRNA-specific probes.

\section{RESULTS}

\section{Analysis of $C$. sativus sRNA population}

Starting from a cDNA library of short sRNAs from $C$. sativus containing 209,331 high quality sequences [17] we selected 38,747 non-redundant reads recovered from cucumber leaves with lengths of 18 to $30 \mathrm{nts}$ to analyze the general profile of cucumber sRNAs. This data set was analyzed using the online University of East Anglia plant sRNA toolkit [18].

Size distribution of unique sequences is summarized in Fig. 1. The majority of the reads $(82.62 \%)$ were in the range of 20 to $24 \mathrm{nt}$ in length, with $24 \mathrm{nts}(51.15 \%)$ being the most represented class of non-redundant species followed by 23 (10.40\%), 22 (9.81\%) and $21 \mathrm{nt}(9.08 \%)$. This result was consistent with that previously reported for other plant species such as Arabidopsis, Medicago truncatula, Oriza sativa, Populus spp. and Citrus trifoliate where 24-nt sRNAs dominate the sRNA transcriptome [6-9, 11, 19]. The analysis of the average abundance of total cucumber sRNAs measured by the ratio of raw and unique sequences revealed that the 24-nt class exhibited high sequence diversity consistent with the widespread origins of sRNAs of this size along plant genomes. Surprisingly, the highest level of redundancy (6.68) was found within the 22 nt sRNA subset (Fig. 1, blue bars).This atypical situation, draw a parallel with the 
relatively high number of redundant 22-nt sequences obtained from C. trifoliate by Solexa (Illumina) high-throughput sequencing [11].
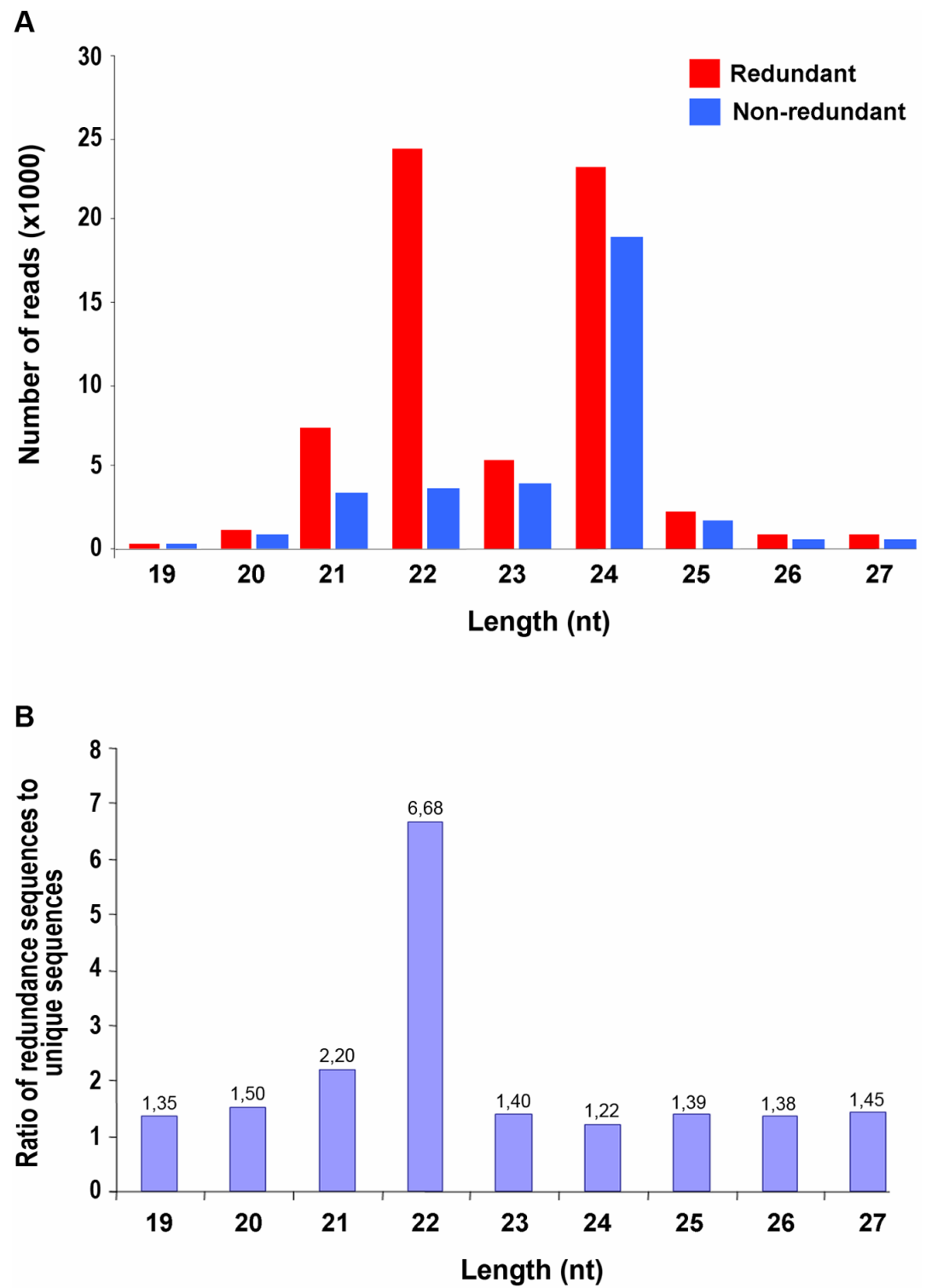

Figure 1. Size distribution of small RNAs (sRNAs) sequences. A) The number of redundant (red bars) and nonredundant (blue bars) sequences recovered from C. sativus sRNA library is expressed as thousand unities. B) Redundancy ratio for cucumber sRNAs.

\section{Identifying known miRNAs in $C$. sativus}

Known miRNAs comprise both conserved and non-conserved miRNA species. In order to identify known miRNAs in our sequenced set of cucumber sRNAs, we compared the sequences recovered from our library with the repository of mature plantmiRNAs in miRBase (Release 16.0, September 2010; http://microrna.sanger.ac.uk) using the miRProf tool of the sRNA tool kit. Based on sequence homology our analysis revealed the presence of 25 known plant-miRNA families in our dataset (Table 1). The 
identified known-miRNAs corresponded to 19 conserved (miR156, miR159, miR160, miR164, miR165, miR166, mi167, miR168, miR169, miR171, miR172, miR319, miR390, miR393, miR396, miR397, miR398, miR398 and miR408) and 6 known but non-conserved (miR170, miR827, miR858, miR894, miR1030 and miR2950) miRNA families. As expected, most of the miRNAs identified in cucumber were highly conserved in diverse plant species [20], suggesting that the ancient regulatory pathways mediated by evolutionary conserved miRNAs are also functional in cucumber plants. The stable expression level of a selected set of conserved miRNAs (miR159, miR167 and miR168) in diverse plant sectors across successive growing phases (Supplementary Fig. S1) strongly supports this idea.

\begin{tabular}{|c|c|c|c|c|c|c|c|c|c|}
\hline \multirow{2}{*}{$\begin{array}{l}\text { miRNA Family } \\
\text { Conserved }\end{array}$} & \multirow[t]{2}{*}{$\underset{\text { range }}{\text { Size }^{a}}$} & \multirow[t]{2}{*}{ miRNA* } & \multirow[t]{2}{*}{5 ' nucleotide } & \multicolumn{6}{|c|}{ Homology by specie } \\
\hline & & & & A. thaliana & O. sativa & P. trichocharpa & R. comunis & M. truncatula & V. vinifera \\
\hline miR156 & $20-23$ & Yes & U (68\%) & Yes & Yes & Yes & Yes & Yes & Yes \\
\hline miR159 & $19-23$ & No & U (77\%) & Yes & Yes & Yes & Yes & Yes & Yes \\
\hline $\operatorname{miR160}$ & $20-21$ & Yes & U (100\%) & Yes & Yes & Yes & Yes & Yes & Yes \\
\hline miR164 & $20-21$ & No & $\cup(67 \%)$ & Yes & Yes & Yes & Yes & Yes & Yes \\
\hline miR165 & 21 & No & U (100\%) & Yes & Yes & No & No & No & No \\
\hline miR166 & $21-22$ & Yes & U (100\%) & Yes & Yes & Yes & Yes & Yes & Yes \\
\hline miR167 & $21-23$ & No & U (87\%) & Yes & Yes & Yes & Yes & Yes & Yes \\
\hline miR168 & $21-22$ & Yes & U (75\%) & Yes & No & Yes & Yes & Yes & Yes \\
\hline miR169 & $21-23$ & Yes & U (75\%) & Yes & No & Yes & No & No & Yes \\
\hline miR171 & $19-23$ & Yes & U $(65 \%)$ & Yes & Yes & Yes & Yes & Yes & Yes \\
\hline miR172 & $19-21$ & Yes & $A / G(50 \%)$ & Yes & Yes & Yes & Yes & Yes & Yes \\
\hline miR319 & $20-21$ & No & U (100\%) & Yes & No & Yes & Yes & Yes & Yes \\
\hline miR390 & $19-21$ & Yes & A $(75 \%)$ & Yes & Yes & Yes & Yes & Yes & Yes \\
\hline miR393 & $21-23$ & No & $\cup(100 \%)$ & Yes & Yes & Yes & Yes & Yes & Yes \\
\hline miR396 & $21-22$ & Yes & $U(100 \%)$ & Yes & Yes & Yes & Yes & Yes & Yes \\
\hline miR397 & 21 & No & C (50\%) & Yes & Yes & Yes & Yes & No & Yes \\
\hline miR398 & $20-21$ & No & U (100\%) & Yes & Yes & Yes & Yes & Yes & Yes \\
\hline miR399 & 21 & No & U ('100\%) & Yes & No & No & No & No & No \\
\hline miR408 & $21-22$ & No & U ('66\%) & Yes & Yes & Yes & Yes & Yes & Yes \\
\hline \multicolumn{10}{|l|}{ Non-conserved } \\
\hline miR170 & $21-22$ & No & $\cup(100 \%)$ & No & No & No & No & No & Yes \\
\hline miR827 & 22 & No & U $(100 \%)$ & No & No & Yes & No & No & No \\
\hline miR858 & 22 & No & U (100\%) & No & No & Yes & Yes & No & No \\
\hline miR894 & $20-21$ & No & $\mathrm{G} / \mathrm{C}(50 \%)$ & No & No & Yes & No & No & No \\
\hline miR1030 & 19 & No & $C(100 \%)$ & No & No & Yes & No & No & No \\
\hline miR2950 & $21-22$ & Yes & $U(100 \%)$ & No & No & No & No & No & Yes \\
\hline
\end{tabular}

Table 1. Known micro RNAs (miRNAs) recovered from our C. sativus sRNA library.

a The column shows the reads encompassing the defined miRNA sequence \pm 2 nts.

Next, potential genomic sources of conserved cucumber miRNAs were identified by Blastn against the cucumber transcript database currently available at http://www.phytozome.net/cucumber.php. Secondary structure analysis revealed that pre-miRNAs holding characteristic secondary structures were predicted for 18 of the 25 miRNA families identified by sequence homology (Supplementary table S1). This finding added robustness to our data obtained by high throughput sequencing. The 
predicted hairpins have a free energy ranging from -37.76 to $-100.91 \Delta \mathrm{G}$ and a predicted length ranging from 85 to 283 nts. The majority (12 out of 18 ) of the conserved miRNA families were composed by more than one member originating from different genomic loci, whereas the totality of the non-conserved known miRNAs arises from a single locus (Fig. 2).

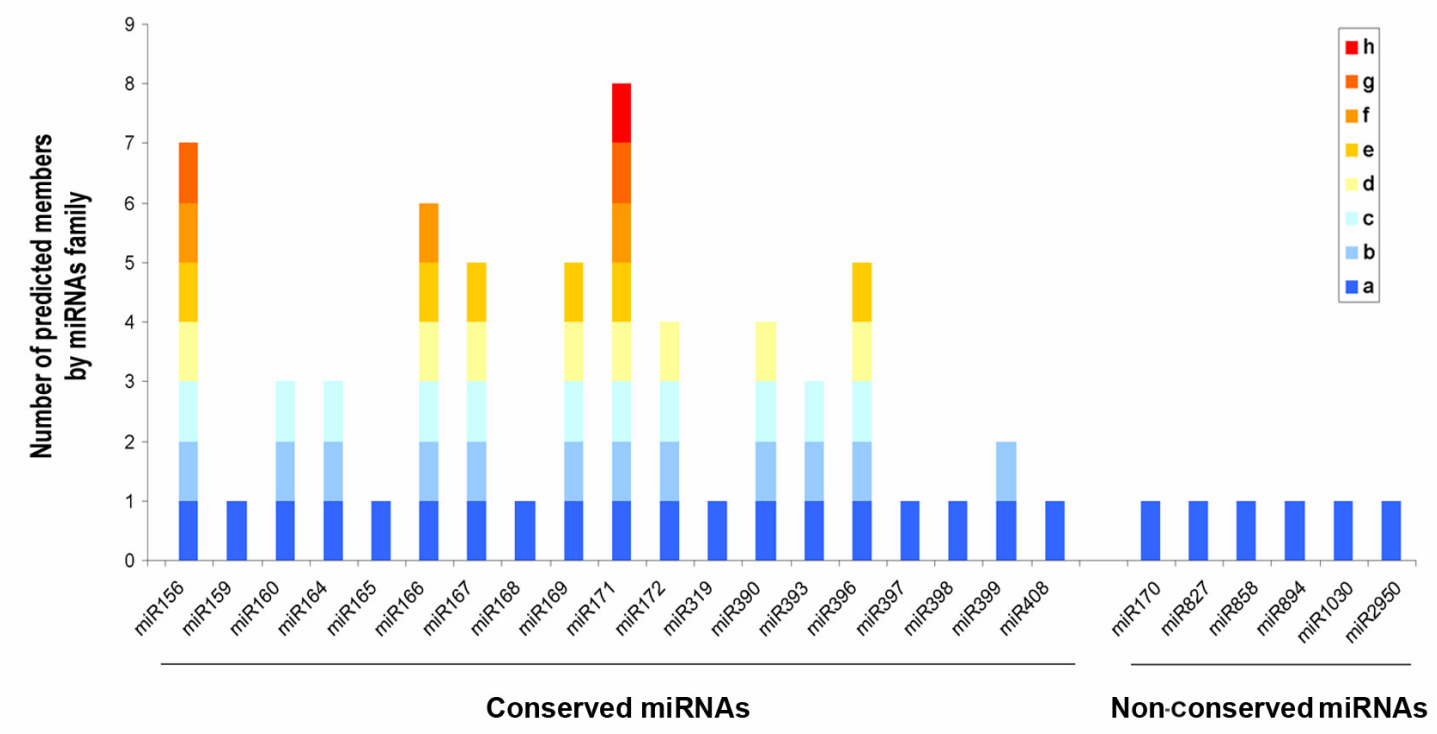

Figure 2. Complexity of the known miRNA families identified in C. sativus. Graphic representation of the different members of each conserved and non conserved miRNA family found in cucumber by sequencing and miRNA precursors prediction (miRCat).

Since high-throughput sRNA sequencing provides the opportunity for quantitative profiling of sRNA populations, sequencing frequencies in our sequenced collection were employed as an estimation of miRNA abundance. Counting of redundant sRNA reads revealed that 14 out of 19 conserved miRNAs were represented with more than 10 reads in the cucumber data set; only miR165, miR399, miR319, miR393 and miR408 had less than ten reads. By contrast, less than 10 reads were counted for most known, non-conserved miRNA families; exceptions were miR858 and 2950 with more than 10 reads in the sequenced set (Fig. 3A). Next, to confirm their expression in cucumber, a representative group of conserved miRNAs were analyzed by Northern blot analysis. As observed in the Fig. 3B, the totality of the tested miRNA were readily detected in the leaves of cucumber plants maintained at two different temperatures (see material and methods) using non-isotopic hybridization techniques, 
suggesting that they were abundant as predicted by their respective sequencing frequencies.

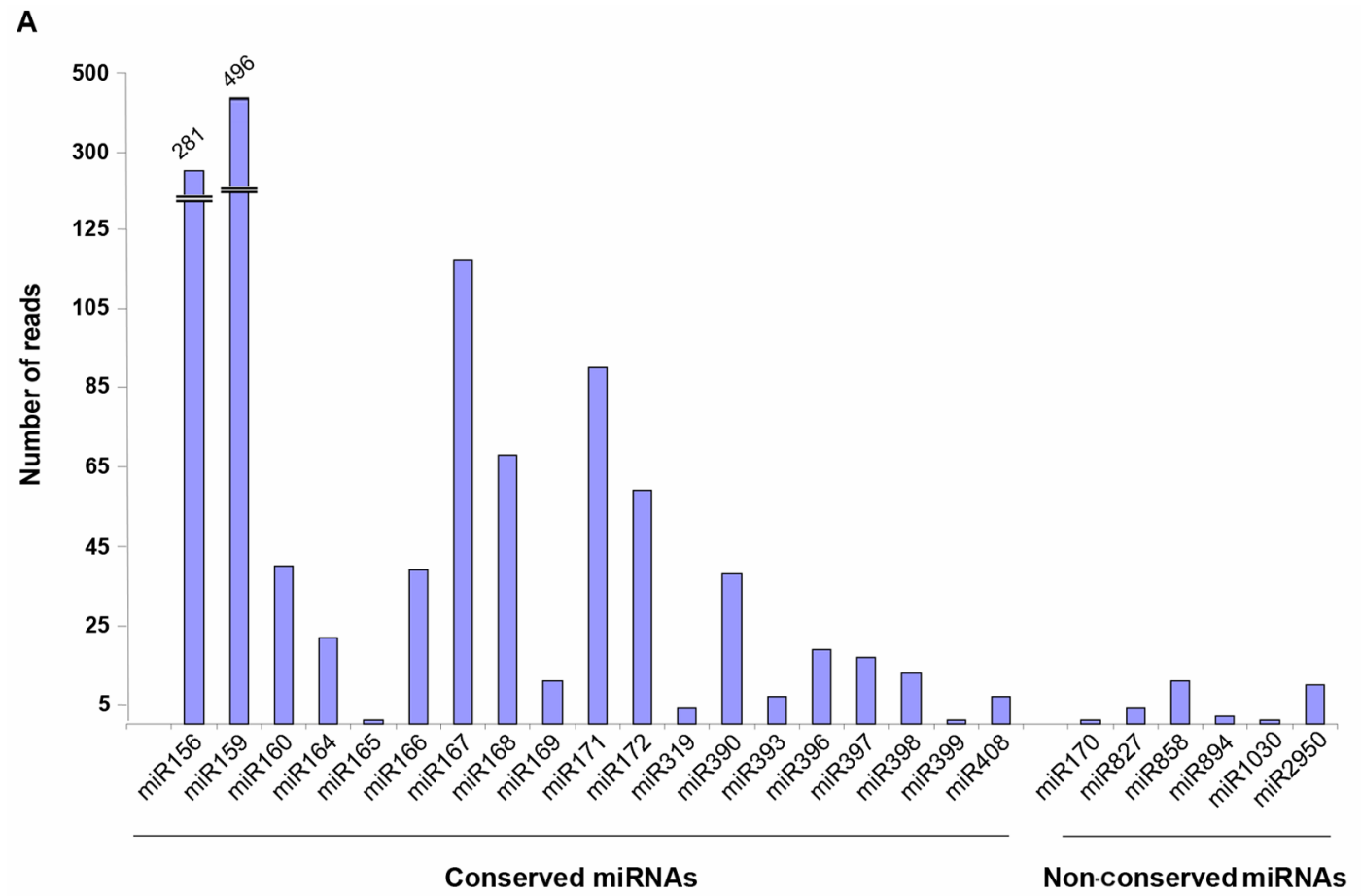

B

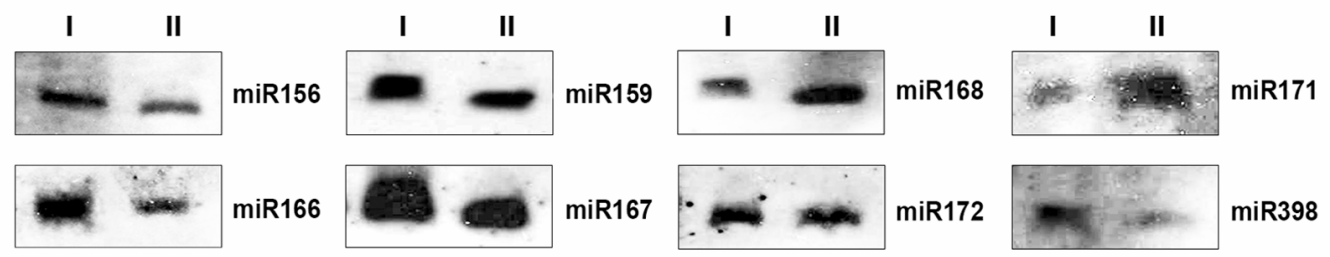

Figure 3. Analysis of known miRNAs found in cucumber.

A) Graphic showing the number of sequences for each (conserved and non-conserved) miRNA family. The values on the $y$-axis represent the abundance of reads in the library.

B) Detection of selected known cucumber miRNAs by Northern blot assays using non isotopic probes. I and II indicate plants maintained at $25^{\circ} \mathrm{C}$ and $30^{\circ} \mathrm{C}$, respectively, resembling the plant growing conditions used for sRNAs library generation.

\section{Identifying new potential miRNAs in $C$. sativus}

To discover additional non-conserved, cucumber-specific miRNA candidates within our sequenced set, unique small RNA species were aligned against the C. sativus genome sequence in order to identify loci that may serve as putative precursors for miRNA. A total of 605 potential candidate new miRNAs were selected for further analysis and classified into three arbitrary categories. Class $\boldsymbol{A}$ comprised sRNAs that had their star counterpart sequenced; class $\boldsymbol{B}$ contained sRNAs that had been sequenced more than 5 times but were not supported by star counterparts; class $\boldsymbol{C}$ included rare 
sRNAs represented by less than five reads in the sequenced set (Fig. 4). Besides, sRNAs that hit the cucumber genome at more than 50 genomic loci were regarded as likely repeat-associated siRNAs and excluded from the analysis.

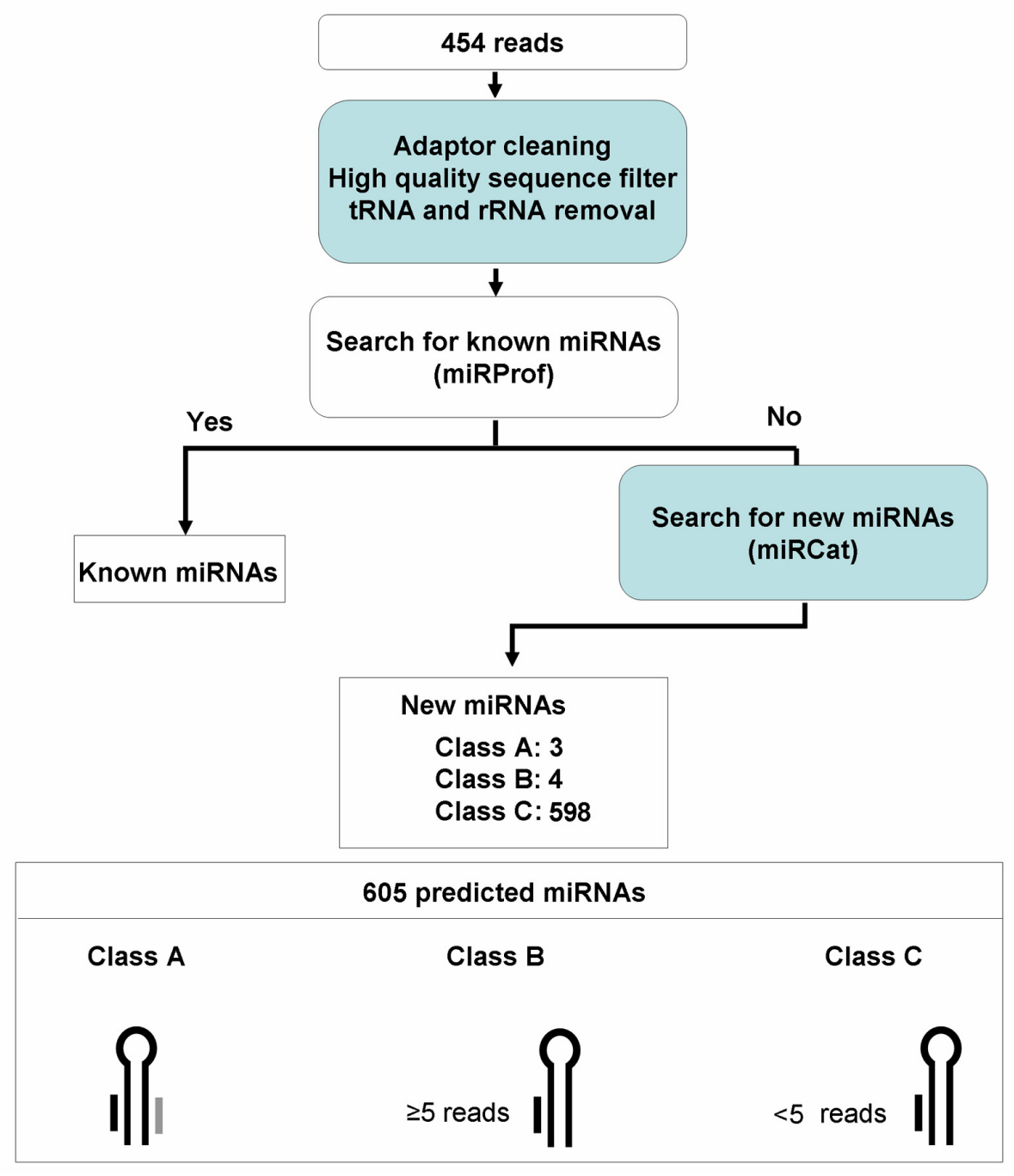

Figure 4. Flowchart for the identification of new miRNAs on C. sativus.

Our analysis revealed 6 possible miRNA sequences deriving from genomic loci with intramolecular folding capacity that resembled the characteristic and predictable local hairpin structures of miRNA precursors (Fig. 5A and Table 2). Three of these candidate miRNAs (csa-miR1, csa-miR2 and csa-miR3) belonged to class $\boldsymbol{A}$, and were considered as authentic miRNAs as they satisfactory fulfilled the expression and biogenesis criteria (sequencing of miRNA* strand) for miRNA annotation. The remaining three sequences belonged to class $\boldsymbol{B}$ (csa-miR4, csa-miR5 and csa-miR6) and were considered as possible candidates because they apparently derived from stem-loop structures and were relatively abundant, but miRNA* species were not sequenced. In 
coincidence with that reported for other plant miRNAs, these newly identified miRNAs derive from predicted hairpin structures ranging from 134 to 230 nts long. The minimum free energies of these pre-miRNA hairpin structures rang from -42.00 to $97.90 \Delta \mathrm{G}$. The described cucumber miRNAs were potentially generated from 7 different loci (Table 2). The new miRNAs included in the class $\boldsymbol{A}$ (csa-miR1, csa-miR2 and csa-miR3) and the candidates (class $\boldsymbol{B}$ ) miRNAs (csa-miR5 and csa-miR6) each arose from a single locus, in good agreement with most species-specific miRNAs detected in other plant species. The candidate csa-miR4 is predicted to be produced from two loci. As expected, none of the new described cucumber-miRNAs was found to be clustered (data not shown), since this organization pattern (common in animals) is infrequent in plants, with the exception of some species like soybean, grapevine or tobacco $[10,21,22]$.

\begin{tabular}{|c|c|c|c|c|c|c|c|c|c|}
\hline csaMiR & Location & Orientation & Abundance & Sequence & $\begin{array}{l}\text { Length } \\
\text { (nt) }\end{array}$ & $\begin{array}{c}\text { Hairpin } \\
\text { Length (nt) }\end{array}$ & $\begin{array}{c}\text { Minimum } \\
\text { Free Energy }\end{array}$ & Class & miRHA* \\
\hline 1 & scaffold03050:42052_42075 & + & 1 & AATTAAGAATATAACAACATTTAA & 24 & 230 & -67.60 & A & AAATGTTGCTATATACTTAATTAT(1) \\
\hline 2 & scaffold04026:144_163 & + & 1 & CCTCATTTTGGTCAACCGGC & 20 & 155 & -49.69 & A & ATCGGTTTACGCACTAATG(1) \\
\hline 3 & scaffold03577:144799_144819 & + & 10 & TGGTCGTCCTGAAAACACATG & 21 & 134 & -42.00 & A & TGTGTTCTCAGGTCGCCCCTG(8) \\
\hline 4_1 & scaffold01087:76_96 & + & 6 & GAAGGCTGTGATGATTATTGA. & 21 & 223 & -97.90 & B & NO \\
\hline 4_2 & scaffold04146:100_120 & + & 6 & GAAGGCTGTGATGATTATTGA & 21 & 225 & -94.50 & B & NO \\
\hline 5 & scaffold02633:580263580284 & - & 10 & TTCCAAGTCCACCCATGCCCGC & 22 & 185 & -72.10 & 8 & NO \\
\hline 6 & scaffold01374:173181_173204 & - & 59 & ATTGAGCTATGCTCGCTTTGGCAA & 24 & 196 & -91.00 & $\theta$ & NO \\
\hline
\end{tabular}

Table 2. Novel miRNAs found in Cucumis sativus

${ }^{a}$ Location of the miRNA sequence on the cucumber genome, indicating the scaffold from which the miRNA derives and the start and end position.

To validate their prediction and examine their expression we analyze leaves of cucumber plants maintained at $25^{\circ} \mathrm{C}$ and $30^{\circ} \mathrm{C}$ temperatures both resembling the plant growing conditions used during the sRNAs library generation. The new cucumber miRNAs were subjected to sRNA hybridization analysis against non-isotopic riboprobes (Fig. 5B). All the Class $\boldsymbol{A}$ cucumber-specific miRNAs (csa-miR1, csa-miR2 and csa-miR3) and 2 out 3 Class $\boldsymbol{B}$ candidate-miRNAs (csa-miR4 and csa-miR6) were detected by Northern blot assays, providing additional robustness at our prediction. The candidate csa-miR5, that shows a low intensity signal at high exposition times, was considered as undetected. 

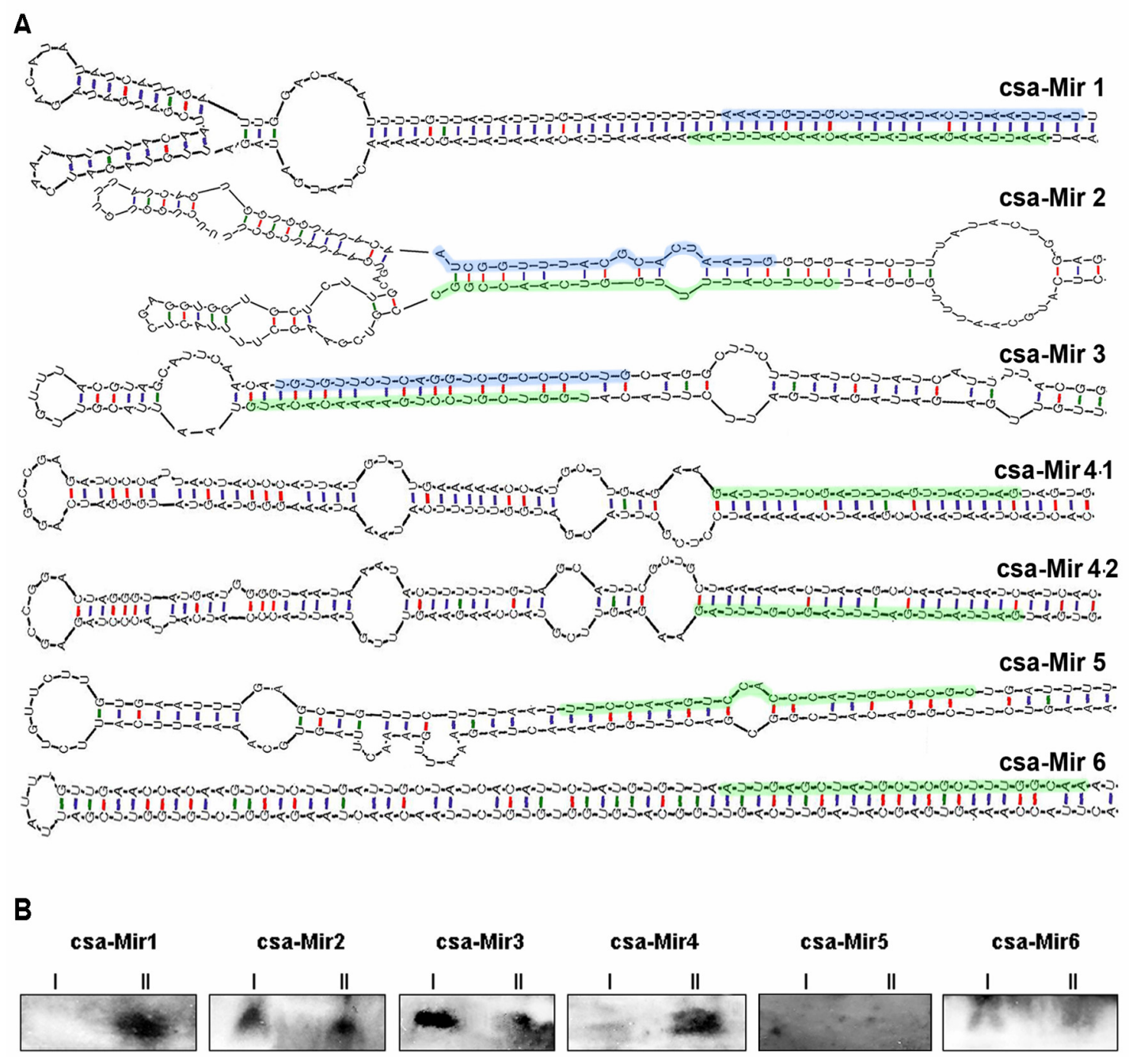

Figure 5. Bioinformatics prediction and Northern blot detection of new C. sativus miRNAs. A) Primary transcripts containing the predicted stem-loop structures precursor of new cucumber miRNAs. The mature miRNAs identified in cucumber sRNAs library are highlighted (green for miRNAs and blue for miRNAs*). The size of the precursors may be slightly longer than represented. B) Low molecular-weight enriched-RNA was extracted from cucumber leaves, electrophoresed and transferred to nylon membranes. The novel cucumber miRNAs were detected by Northern blot assays using non isotopic probes. I and II indicate plants maintained at $25^{\circ} \mathrm{C}$ and $30^{\circ} \mathrm{C}$, respectively, resembling the plant growing conditions used for sRNAs library generation.

\section{Prediction of miRNA targets in $C$. sativus}

With the aim to better understand the biological functions of the newly identified as well as known (conserved and non-conserved) C. sativus miRNAs, we searched for putative target genes by using the plant target prediction tool of the sRNA tools (http://srna-tools.cmp.uea.ac.uk/plant/cgi-bin/srna-tools) and the C. sativus 
transcript database (http://www.phytozome.net/cucumber.php) as the reference set. As a result, we found putative target genes for 1 out of 3 new cucumber miRNAs and for 2 out of 3 candidate cucumber miRNAs (Table 3 ). Since, the recently sequenced cucumber genome has not been functionally annotated yet, we searched for homologous proteins for these cucumber transcripts in the NCBI protein-database (www.ncbi.nlm.nih.gov) in order to infer the biological functions of their predicted targets. The known proteins, homologous to the putative target genes, appear to be involved in a wide variety of biological processes (Table 3 ).

\begin{tabular}{|c|c|c|c|c|}
\hline miRNA & C.sativus target gene accession & start-end position of target & Target translation & Specie \\
\hline 1 & No target found & & & \\
\hline 2 & Cucsa. 328090.2 & $147-166$ & Tetratricopeptide repeat (TPR)-containing protein (AT1G77230) & A.thaliana \\
\hline 3 & No target found & & & \\
\hline 4_1 & Cucsa.250100.1 & $860-876$ & Nodulin MtN21 farnily protein (AT5G64700) & A.thaliana \\
\hline 4_1 & Cucsa.395290.1 & $1435-1448$ & Clathrin binding protein (At5g11710) & A.thaliana \\
\hline 4_2 & Cucsa.250100.1 & $860-876$ & Nodulin MtN21 farmily protein (AT5G64700) & A.thaliana \\
\hline 4_2 & Cucsa. 395290.1 & $1435-1448$ & Clathrin binding protein (At5g11710) & A.thaliana \\
\hline 5 & Cucsa.251930.1 & $592-613$ & R-FOM-2 gene & C.melo \\
\hline 5 & Cucsa. 368410.1 & $733-754$ & r2r3-myb transcription factor, putative & R.communis \\
\hline 6 & No target found & & & \\
\hline
\end{tabular}

Table 3. Predicted targets of new cucumber miRNAs

For example, the predicted csa-miR2 target was a gene coding a tetratricopeptide repeat-containing protein, a kind of proteins involved in protein-protein and/or proteinRNA interactions. Candidate csa-miR4/1 and 4/2 had two predicted targets, a nodulin similar to MtN21 family protein which are related to vascular tissue development, nodule formation and transport functions, and a clathrin binding protein involved in plant endocytosis. Csa-miR5 targets are R-FOM2, a resistance gene to Fussarium oxysporum f.sp. melonis from C. melo, and a r2r3-myb transcription factor which plays important roles in the regulation of many secondary metabolites at the transcriptional level. To obtain more complete information, we blasted against the cucumber draft genome the potential cucumber specific miRNAs with unpredicted target in the coding transcriptome. This analysis revealed that csa-Mir1 and csa-Mir6 posses highly homology ( $>91 \%$ ) with diverse RNA regions no identified as protein coding (data no shown). No homology region (except the corresponding to miRNA precursor) was identified in the cucumber genome for csa-Mir3. 
Next, we explored the $C$. sativus transcript database searching for predicted target genes of the previously known cucumber miRNAs described in this study. Putative targets were found in the cucumber transcriptome for the majority of these conserved and non-conserved known miRNAs (Table 4). Additionally, we compare for a representative set of conserved cucumber miRNAs, the target genes predicted in cucumber with the previously reported targets. As expected, all of these miRNAs share putative target genes with their homologous miRNAs in other plant-species (data not shown), reinforcing the idea that conserved plant-miRNAs are involved in essentials biological processes.

\begin{tabular}{|c|c|c|}
\hline miRNA & Targeted cucumber gene & Targeted inferred protein \\
\hline \multicolumn{3}{|l|}{ Conserved } \\
\hline miR156 & $\begin{array}{c}\text { Cucsa. } 054050.1 \text {.Cucsa. } 113410.2 \text {. Cucsa. } 157230.1 \text {. Cucsa. } 198630.1 \\
\text { Cucsa.242790.1. Cucsa. } 392170.1 \text {. Cucsa. } 349620.1 \text {.Cucsa. } 259800.1 \\
\text { Cucsa. } 291270.1 \\
\text { Cucsa. } 303890.4\end{array}$ & $\begin{array}{l}\text { Squamosa promoter binding protein } \\
\text { Cationic amino acid transporter } \\
\text { Short-chain dehydrogenase }\end{array}$ \\
\hline miR159 & $\begin{array}{c}\text { Cucsa. } 0941801 . \text { Cucsa. } 121070.1 \text {. Cucsa. } 148580.1 \text {. Cucsa. } 364400.1 \\
\text { Cucsa. } 094180.1 \text {. Cucsa. } 121070.1 \text {. Cucsa. } 364400.1 \text {. Cucsa. } 148580.1 \\
\text { Cucsa. } 047860.3 \text {. Cucsa.111880.2 } \\
\text { Cucsa.273670.1 } \\
\text { Cucsa. } 283050.1 \\
\text { Cucsa.283050.1 }\end{array}$ & $\begin{array}{l}\text { R2R3-MYB transcription factor } \\
\text { TCP transcription factor } \\
\text { BRASSINAZOLLE-RESISTANT } 2 \text { protein } \\
\text { ARIADNE-like protein } \\
\text { pre-miRNA 395e }\end{array}$ \\
\hline miR160 & Cucsa.308310.1 & miR160c gene \\
\hline \multirow[t]{2}{*}{ miR164 } & $\begin{array}{r}\text { Cucsa.040380.1 } \\
\text { Cucsa.122890.1 }\end{array}$ & $\begin{array}{l}\text { NAC transcription factor } \\
\text { CUC transcription factor }\end{array}$ \\
\hline & $\begin{array}{c}\text { Cucsa. } 032500.1 \text {. Cucsa. 112890.1. Cucsa. } 158180.2 \text {. } \\
\text { Cucsa. } 197830.1 \text {. Cucsa. } 338700.3\end{array}$ & NAM transcription factor \\
\hline miR165 & $\begin{array}{l}\text { Cucsa. } 048220.1 \\
\text { Cucsa. } 167110.5 \text {. Cucsa. } 385410.3 \text {, Cucsa. } 386080.9\end{array}$ & $\begin{array}{l}\text { PHB transcription factor } \\
\text { Class III HD-Zip protein }\end{array}$ \\
\hline miR166 & Cucsa. 341260.1 & PRA-7 protein \\
\hline miR167 & $\begin{array}{l}\text { Cucsa.047990.2. Cucsa. } 152170.3 \text {. Cucsa.173450.1 } \\
\text { Cucsa.097070.2 } \\
\text { Cucsa. } 139150.1 \\
\text { Cucsa.160570.1 }\end{array}$ & $\begin{array}{l}\text { Auxin response factor } \\
\text { Magnesium } / \text { proton exchanger } \\
\text { CDC6 } \\
\text { MYB transcription factor }\end{array}$ \\
\hline miR168 & No target found & \\
\hline miR169 & Cucsa. 055300.1 & Tubulin gamma complex-associated proteir \\
\hline miR171 & $\begin{array}{l}\text { Cucsa. } 120600.1 \text {. Cucsa. } 201250.1 \\
\text { Cucsa. } 320850.2\end{array}$ & $\begin{array}{l}\text { Scarecrow-like transcription factor } \\
\text { GRAS transcription factor }\end{array}$ \\
\hline miR172 & $\begin{array}{l}\text { Cucsa.065640.1.Cucsa.102550.1.Cucsa. 165940.1.Cucsa. } 307230.1 \\
\text { Cucsa.385890.1 }\end{array}$ & $\begin{array}{l}\text { Apetala } 2 \text { transcription factor } \\
\text { pre-miRNA } 172 a\end{array}$ \\
\hline miR319 & $\begin{array}{l}\text { Cucsa. } 283050.1 \\
\text { Cucsa.302420.2 } \\
\text { Cucsa. } 364400.1\end{array}$ & $\begin{array}{l}\text { miR395e promary transcript } \\
\text { Zinc finger protein } \\
\text { MYB transcription factor }\end{array}$ \\
\hline miR390 & $\begin{array}{l}\text { Cucsa. } 089280.1 \\
\text { Cucsa. } 164200.1\end{array}$ & $\begin{array}{l}\text { ZEITLUPE protein } \\
\text { Lucine-rich repeat receptor-like protein }\end{array}$ \\
\hline miR393 & $\begin{array}{l}\text { Cucsa. } 156100.1 \\
\text { Cucsa. } 196530.1\end{array}$ & $\begin{array}{l}\text { Auxin signaling f-box } 2 \\
\text { Dead box ATP-dependent RNA helicase }\end{array}$ \\
\hline miR396 & No target found & \\
\hline miR397 & $\begin{array}{l}\text { Cucsa. } 066920.1 \text {. Cucsa.067060.1. Cucsa. } 124400.1 \\
\text { Cucsa.146870.1. Cucsa.175530.1. Cucsa. } 176130.1 \\
\text { Cucsa.266970.1 }\end{array}$ & $\begin{array}{l}\text { Laccase } \\
\text { Ubiquitin }\end{array}$ \\
\hline miR398 & No target found & \\
\hline miR399 & No target found & \\
\hline miR408 & $\begin{array}{l}\text { Cucsa.077170.1. Cucsa.033180.1, Cucsa.049510.1 } \\
\text { Cucsa.271070.1 }\end{array}$ & $\begin{array}{l}\text { Cooper ion binding (Plantacyanin) } \\
\text { P1b-ATPase }\end{array}$ \\
\hline \multicolumn{3}{|l|}{ Non-conserved } \\
\hline miR170 & No target found & \\
\hline miR827 & No target found & \\
\hline miR858 & $\begin{array}{l}\text { Cucsa.096800.1, Cucsa.365190.1, Cucsa.340790.2, } \\
\text { Cucsa.107730.1, Cucsa.107740.2, Cucsa.006170.1 }\end{array}$ & R2R3 MYB transcription factor \\
\hline miR894 & $\begin{array}{l}\text { Cucsa. } 302080.1 \\
\text { Cucsa. } 103010.1 \\
\text { Cucsa. } 195680.2\end{array}$ & $\begin{array}{l}\text { Acid invertase } \\
\text { RNA binding protein } \\
\text { Chloroplast protease }\end{array}$ \\
\hline miR1030 & $\begin{array}{l}\text { Cucsa.254940.1 } \\
\text { Cucsa.103950.2, Cucsa.034730.1 } \\
\text { Cucsa.298340.1 }\end{array}$ & $\begin{array}{l}\text { TZP; DNA binding / nucleic acid binding } \\
\text { Chromosome condensation protein-like } \\
\text { Trypsin inhibitor } 5\end{array}$ \\
\hline miR2950 & $\begin{array}{l}\text { Cucsa.010860.2 } \\
\text { Cucsa.022840.1 } \\
\text { Cucsa.253640.1 } \\
\text { Cucsa.271250.1 } \\
\text { Cucsa.310310.1 } \\
\text { Cucsa.097890.1 }\end{array}$ & $\begin{array}{c}\text { APK1A } \\
\text { Acetolactate synthase } \\
\text { DEAD box RNA helicase } \\
\text { F-box family protein } \\
\text { Clathrin assembly protein } \\
\text { WRKY transcription factor }\end{array}$ \\
\hline
\end{tabular}

Table 4. Predicted targets of conserved and non-conserved cucumber miRNAs 


\section{DISCUSSION}

Micro RNAs are key components of most of the regulatory events mediated by RNA silencing in animal and plants [23-25]. Although the development of highthroughput sequencing methods have contributed in detecting new as well as evolutionary conserved miRNAs [26], most of the species-specific miRNAs that frequently have low or tissue specific expression levels remain yet unidentified. By taking advantage of the recent completion of the sequence of the cucumber genome, the aim of this work was to identify the evolutionary conserved and new cucumber-specific miRNAs present in a $C$. sativus sRNAs population recovered from a cDNA library of cucumber sRNAs [17]. Our data indicated that cucumber sRNA of $24 \mathrm{nt}$ dominated the pool of unique species as observed for many other herbaceous species such as $A$. thaliana, M. truncatula and S. Licopersicum where 24 nts length were the most represented sRNAs [6-9, 19]. This high proportion of 24-nt class sRNAs in annual plants could be consequence of an active state of heterochromatin transcriptional silencing (mediated by 24-nt sRNAs) rapidly established at each generation [10]. It has been hypothesized that MIR genes originate by gene duplication events followed by random mutation processes to evolve in multiples imperfectly paired hairpins $[5,27]$. Consequently, ancient evolutionary conserved miRNAs are represented by multiple MIR genes whereas non-conserved miRNAs (believed to be evolutionary recent) are generally originated from a single locus. The search for known miRNAs in cucumber has revealed a total of 25 (19 conserved and 6 non-conserved) miRNA families homologous to miRNAs sequences present on miRBase. Similarly to the commonly reported in other deep sequencing studies [9-11] some of the conserved miRNAs were not found in cucumber sRNAs data set. This situation could be explained keeping in mind that most of the conserved miRNAs reported to date are tissue-specific and thus, not necessarily being represented in our leaf library. As expected, the great majority of the evolutionary conserved miRNAs were represented by more than one member, whereas non-conserved miRNAs identified in this study were represented by a single MIR gene.

In addition, three new cucumber miRNAs (csa-miRNAs), supported by their miRNA* strands have been identified in our $C$. sativus sRNA libraries. Other three miRNAs remains as plausible candidates as their antisense sequences could not be isolated. Moreover, 5 of these csa-miRNAs were validated by northern blot detection, 
which is an important requisite for the identification of new miRNAs. Based in BLASTn search against the cucumber genome and hairpin structure prediction, we identified genomic sources of miRNA and potential precursors for the totality of the new and candidate csa-miRNAs. These miRNAs are potentially generated from 7 loci and, as commonly observed in other plants, do not form transcriptional clusters. Since these miRNAs were not similar to any known miRNAs, they might be involved in more specific processes in cucumber. Unfortunately, we were not able to determine their DCL1 dependence because cucumber $d c l 1$ mutants are currently not available.

The majority of the new cucumber miRNAs identified here showed the canonical size expected for sRNAs derived from DCL1 processing, although sequence variants that possessed shortened or lengthened 5' or 3' ends were also found. For instance, csa-miR3 and csa-miR4 were 21-nt long, consistent with canonical DCL1 products, whereas csa-miR2 (20 nt) and csa-miR5 (22 nt) showed a very little size variation, perhaps due to inaccuracy of DCL1 processing [7]. Only two cucumber miRNAs (cas-miR1 and cas-miR6 - 24nt) showed unexpected sizes. This situation could be similar to that previously observed in Arabidopsis, where diverse miRNA families are also independently processed by DCL3 to generate a new class of bona fide (23 - $25 \mathrm{nt}$ ) miRNAs with no canonical size, called long miRNAs [28]. Additionally, it was also reported that the accumulation of long miRNAs in A. thaliana was inversely proportional to the level of miRNA conservation and exhibit organ-specific expression patterns [28]. A similar situation was recently reported for miRNAs recovered from different grapevine tissues [10]. Future studies are necessary to determine if alternative and tissue-specific DCL processing of miRNA precursors also occur during C. sativus miRNA biogenesis.

Species-specific miRNAs are believed to be recently evolved and, in general, expressed at levels lower than those of strictly conserved miRNAs [5-7, 10, 29]. Our quantitative data obtained from sequencing frequencies of conserved and non-conserved miRNAs accommodates well to this prediction, and indicated that new cucumber miRNAs exhibited residual accumulation in the tissue tested. In comparison to recent reports in other plant species such as grapevine [10], populus [30] or medicago [9] the number the potential specie-specific miRNAs found in cucumber ( 3 specific miRNAs with *miRNA sequence) was considerably low. Although this observation could be assumed as a preliminary evidence that in cucumber the regulatory network mediated by 
specific miRNAs could be less complex that in other species, the tissue-specific nature of our library (leaves of adult plants) can again explain this low number.

Potential targets, with a wide variety of predicted functions, were identified for 4 potential new cucumber miRNAs. In concordance with previous reports most of the targets found in the cucumber transcriptome were plant specific factors related with the transcription machinery, such as the members of the MYB family $(r 2 r 3-m y b)$ or regulatory proteins involved in protein-protein and/or protein-RNA interactions. The biological importance of the potential regulation of these cucumber genes by miRNAs needs further studies. Surprisingly, for 3 new miRNAs (csa-miR1, csa-miR3 and csamiR6) predicted targets in C. sativus transcriptome could not be found. However, homologous regions, candidates to be potential targets for csa-Mir1 and csa-Mir6 were identified in non-coding genomic-regions. This observation opened the possibility that these specific miRNAs could regulate the expression of cucumber non-coding RNAs, and consequently be involved in a more complex regulatory pathways related to epigenetic processes [31]. However, the possibility that the target regions found in the recently sequenced cucumber genome remains to be correctly annotated or that the cucumber transcript dataset was still incomplete can not be ruled out. Future studies are necessary to elucidate the functional importance of these csa-miRNAs. Finally, the highly restrictive algorithms used in this approaches [32] could fail to identify the potential targets for some miRNAs (maybe because the existence of mismatches between the miRNA and their target), resembling the recently observed for the miR398 in Arabidopsis [33].

In summary, in this study we have identified, for the first time, conserved, known non-conserved and new miRNAs in cucumber, using a combined approach of high throughout sequencing and bioinformatics prediction of MIR precursors. In addition, a significant number of these miRNAs were validated by northern blot hybridization fulfilling the requirements necessary to the annotation of new plantmiRNAs $[12,13]$.

\section{MATERIALS AND METHODS}

\section{Small RNA library information}

The sequences used in this work were obtained from a library generated starting from a sRNAs population recovered from leaves and phloem exudate of healthy and 
Hop stunt viroid-infected cucumber (C. sativus) plants and sequenced by 454 Life Science Technology (Lifesequencing, Branfor, CT, USA; www.lifesequencing.com) ([17]-NCBI/SRA accession code SRP001408).

\section{Bioinformatics analysis of sRNA sequences and targets prediction}

Adapter trimming and cleaning of the 454 reads obtained from leaves of noninfected cucumber plants were performed by Perl scripts locally developed by the Bioinformatics Service at the Instituto de Biología Molecular y Celular de Plantas (IBMCP), Valencia, Spain (http://www.ibmcp.upv.es). Next, rRNA, tRNA, snRNA and snoRNA derived sequences were removed from our sRNAs dataset; the remaining sequences were used in this study. The unique sRNA sequences were employed to analyze the sRNAs accumulation profiles and to identify in the miRNA database (miRBase 13.0) known (conserved and non-conserved) miRNAs in cucumber. The sequences ranging the canonical miRNA length \pm 2 nt were considered to be known miRNAs.

To study potential precursor of new cucumber miRNAs, the sRNA sequences recovered from our library were aligned with $C$. sativus transcript database (http://www.phytozome.net/cucumber.php) and then were processed by miRCat of the small RNA toolkit from the University of East Anglia (http://srnatools.cmp.uea.ac.uk/plant/cgi-bin/srna-tools.cgi). The resulting structures, with minimal matched nucleotide pairs of miRNA and miRNA* exceeding $16 \mathrm{nt}$ and with maximal size differences of miRNA and miRNA* up to $4 \mathrm{nt}$, were retained as new miRNA candidates. The sequence of the targets from $C$. sativus were searched against the protein database of the NCBI (National Center for Biotechnology Information, http://www.ncbi.nlm.nih.gov/ ) using the blastx (translated nucleotide search against protein database) option of the blast search.

\section{RNA isolation and Northern blot assays}

Cucumber plants were maintained in environmentally controlled growing chambers at two different temperatures $30^{\circ} \mathrm{C}$ and $25^{\circ} \mathrm{C}$, resembling the growing conditions used for sRNAs library generation [17]. Total RNA was extracted from leaves using TRI reagent (Sigma, St. Louis, MO, USA) according to the manufacturer's instructions. The low-molecular-weight RNA fraction was enriched using the miRNA Isolation Kit MIRACLE (Stratagene, La Jolla, CA, USA). Low molecular-weight 
enriched-RNA was loaded onto $20 \%$ polyacrylamide gels with $0.25 \mathrm{x}$ TBE and $8 \mathrm{M}$ urea. RNA was transferred to a nylon membrane (Roche Diagnostics $\mathrm{GmbH}$ ). Hybridization using different digoxigenin-labelled RNA as a probe was performed as described previously [34]. 


\section{REFERENCES}

1. Llave C, Xie Z, Kasschau KD, Carrington JC (2002) Cleavage of Scarecrow-like mRNA targets directed by a class of Arabidopsis miRNA. Science 297: 2053-2056.

2. Reinhart BJ, Weinstein EG, Rhoades MW, Bartel B, Bartel DP (2002) MicroRNAs in plants. Genes Dev 16: 1616-1626.

3. Xie Z, Khanna K, Ruan S (2010) Expression of microRNAs and its regulation in plants. Seminars in Cell \& Developmental Biology 21: 790-797.

4. Jones-Rhoades MW, Bartel DP, Bartel B (2006) MicroRNAS and their regulatory roles in plants. Annual Review of Plant Biology 57: 19-53.

5. Allen E, Xie Z, Gustafson AM, Sung GH, Spatafora JW, et al. (2004) Evolution of microRNA genes by inverted duplication of target gene sequences in Arabidopsis thaliana. Nature Genetics 36: 1282-1290.

6. Fahlgren N, Howell MD, Kasschau KD, Chapman EJ, Sullivan CM, et al. (2007) High-throughput sequencing of Arabidopsis microRNAs: evidence for frequent birth and death of MIRNA genes. PLoS ONE 2: e219.

7. Rajagopalan R, Vaucheret H, Trejo J, Bartel DP (2006) A diverse and evolutionarily fluid set of microRNAs in Arabidopsis thaliana. Genes \& Development 20: $3407-3425$.

8. Moxon S, Jing R, Szittya G, Schwach F, Rusholme Pilcher RL, et al. (2008) Deep sequencing of tomato short RNAs identifies microRNAs targeting genes involved in fruit ripening. Genome Research 18: 1602-1609.

9. Szittya G, Moxon S, Santos DM, Jing R, Fevereiro MP, et al. (2008) Highthroughput sequencing of Medicago truncatula short RNAs identifies eight new miRNA families. BMC Genomics 9: 593.

10. Pantaleo V, Szittya G, Moxon S, Miozzi L, Moulton V, et al. (2010) Identification of grapevine microRNAs and their targets using high-throughput sequencing and degradome analysis. Plant Journal 62: 960-976.

11. Song C, Wang C, Zhang C, Korir NK, Yu H, et al. (2010) Deep sequencing discovery of novel and conserved microRNAs in trifoliate orange (Citrus trifoliata). BMC Genomics 11: 431.

12. Ambros V, Bartel B, Bartel DP, Burge CB, Carrington JC, et al. (2003) A uniform system for microRNA annotation. RNA 9: 277-279. 
13. Meyers BC, Axtell MJ, Bartel B, Bartel DP, Baulcombe D, et al. (2008) Criteria for annotation of plant MicroRNAs. Plant Cell 20: 3186-3190.

14. Tanurdzic M, Banks JA (2004) Sex-determining mechanisms in land plants. Plant Cell 16 Suppl: S61-71.

15. Lough TJ, Lucas WJ (2006) Integrative plant biology: role of phloem longdistance macromolecular trafficking. Annual Review of Plant Biology 57: 203-232.

16. Huang S, Li R, Zhang Z, Li L, Gu X, et al. (2009) The genome of the cucumber, Cucumis sativus L. Nature Genetics 41: 1275-1281.

17. Martinez G, Donaire L, Llave C, Pallas V, Gomez G (2010) High-throughput sequencing of Hop stunt viroid-derived small RNAs from cucumber leaves and phloem. Molecular Plant Pathology 11: 347-359.

18. Moxon S, Schwach F, Dalmay T, Maclean D, Studholme DJ, et al. (2008) A toolkit for analysing large-scale plant small RNA datasets. Bioinformatics 24: 22522253.

19. Morin RD, Aksay G, Dolgosheina E, Ebhardt HA, Magrini V, et al. (2008) Comparative analysis of the small RNA transcriptomes of Pinus contorta and Oryza sativa. Genome Research 18: 571-584.

20. Sunkar R, Zhou X, Zheng Y, Zhang W, Zhu JK (2008) Identification of novel and candidate miRNAs in rice by high throughput sequencing. BMC Plant Biology 8: 25.

21. Frazier TP, Xie F, Freistaedter A, Burklew CE, Zhang B (2010) Identification and characterization of microRNAs and their target genes in tobacco (Nicotiana tabacum). Planta 232: 1289-1308.

22. Wang Y, Li P, Cao X, Wang X, Zhang A, et al. (2009) Identification and expression analysis of miRNAs from nitrogen-fixing soybean nodules. Biochem Biophys Res Commun 378: 799-803.

23. Poethig RS (2009) Small RNAs and developmental timing in plants. Current Opinion in Genetics \& Development 19: 374-378.

24. Voinnet O (2009) Origin, biogenesis, and activity of plant microRNAs. Cell 136: 669-687.

25. Husbands AY, Chitwood DH, Plavskin Y, Timmermans MC (2009) Signals and prepatterns: new insights into organ polarity in plants. Genes \& Development 23: 1986-1997. 
26. Shabalina SA, Koonin EV (2008) Origins and evolution of eukaryotic RNA interference. Trends in Ecology \& Evolution 23: 578-587.

27. Axtell MJ, Bowman JL (2008) Evolution of plant microRNAs and their targets. Trends in Plant Science 13: 343-349.

28. Vazquez F, Blevins T, Ailhas J, Boller T, Meins F, Jr. (2008) Evolution of Arabidopsis MIR genes generates novel microRNA classes. Nucleic Acids Research 36: 6429-6438.

29. Yao Y, Guo G, Ni Z, Sunkar R, Du J, et al. (2007) Cloning and characterization of microRNAs from wheat (Triticum aestivum L.). Genome Biology 8: R96.

30. Klevebring D, Street NR, Fahlgren N, Kasschau KD, Carrington JC, et al. (2009) Genome-wide profiling of populus small RNAs. BMC Genomics 10: 620.

31. Rymarquis LA, Kastenmayer JP, Huttenhofer AG, Green PJ (2008) Diamonds in the rough: mRNA-like non-coding RNAs. Trends in Plant Science 13: 329-334.

32. Alves L, Jr., Niemeier S, Hauenschild A, Rehmsmeier M, Merkle T (2009) Comprehensive prediction of novel microRNA targets in Arabidopsis thaliana. Nucleic Acids Research 37: 4010-4021.

33. Beauclair L, Yu A, Bouche N (2010) microRNA-directed cleavage and translational repression of the copper chaperone for superoxide dismutase mRNA in Arabidopsis. Plant Journal 62: 454-462.

34. Gomez G, Pallas V (2007) Mature monomeric forms of Hop stunt viroid resist RNA silencing in transgenic plants. Plant Journal 51: 1041-1049. 


\section{SUPPORTING INFORMATION}

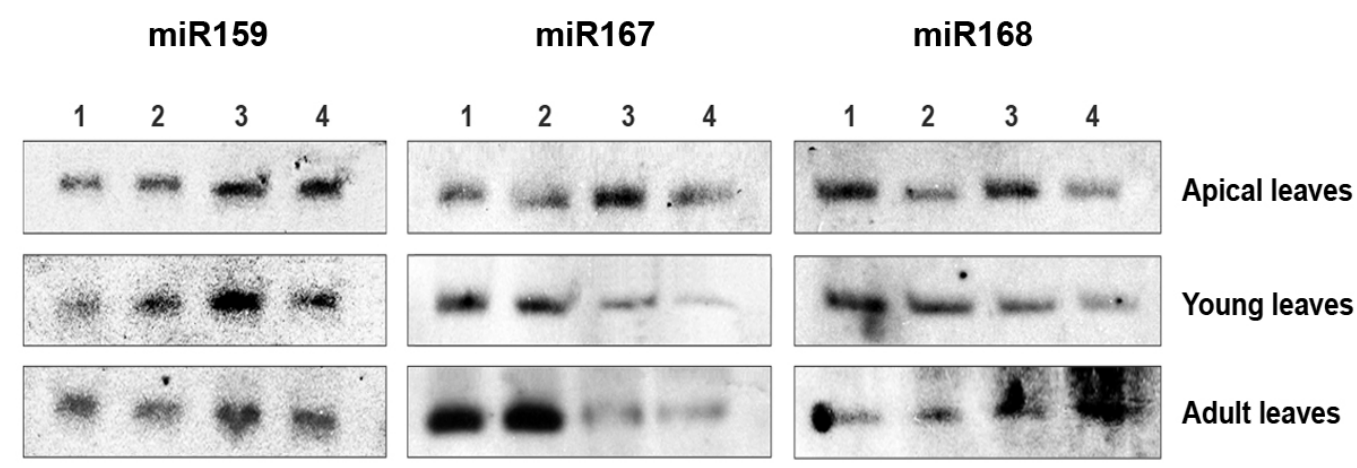

Figure S1. Northern blot detection of miR159, miR167 and miR168 in cucumber plants. The leaves were weekly collected from 4 (one group for week) independent groups of 3 different plants and pooled, before the RNA extraction. The samples were recovered at 5, 6, 7 and 8 weeks after germination (lanes 1 to 4, respectively). The 3 different plant sectors analyzed (apex, young leaves and old leaves) correspond to: first apical leaves (apex), third leaves from the shoot apex (young leaves) and fifth leaves from the shoot apex (old leaves). 
Table S1. Conserved and known but non-conserved miRNA families predicted by miRCat in cucumber transcriptome.

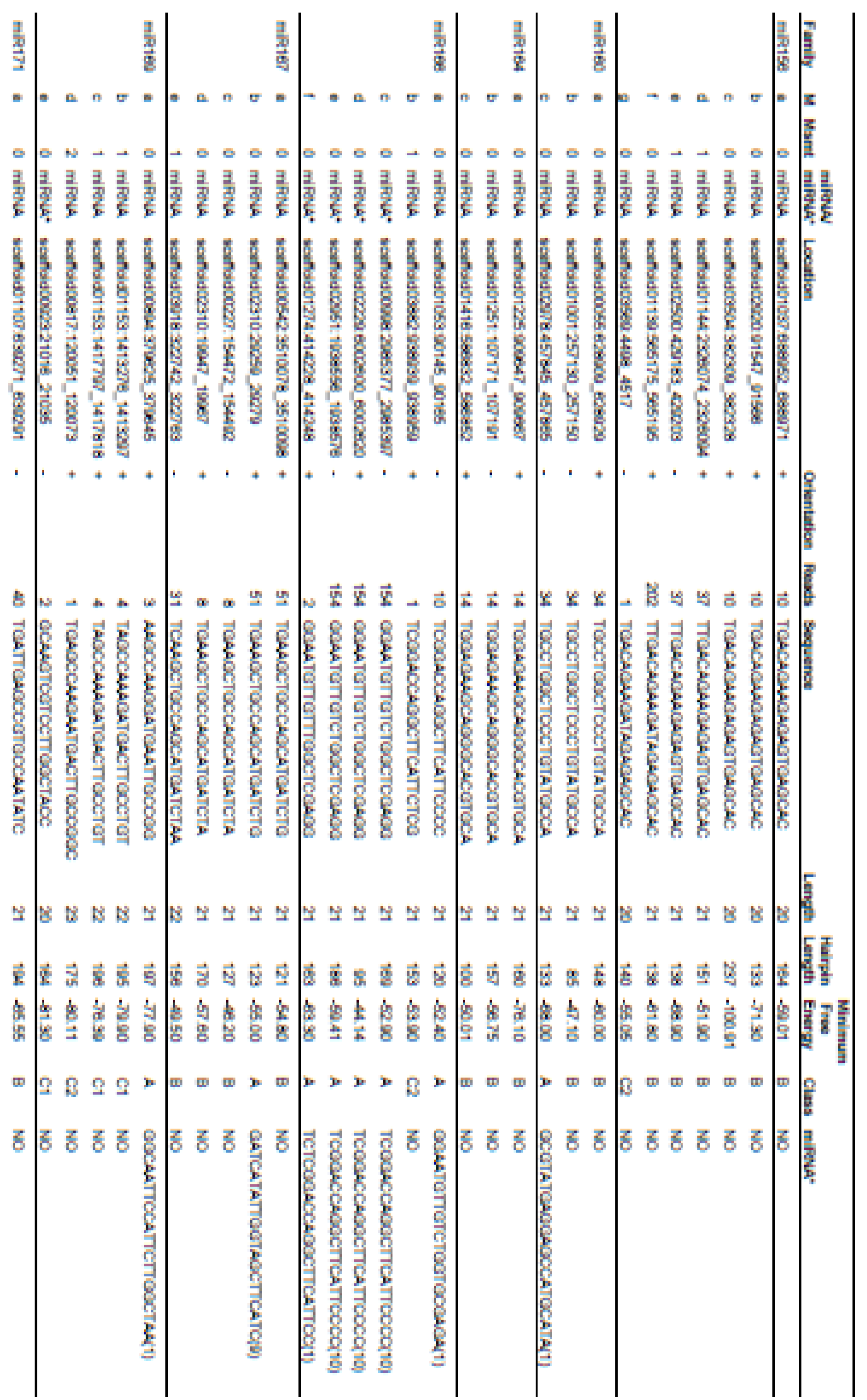




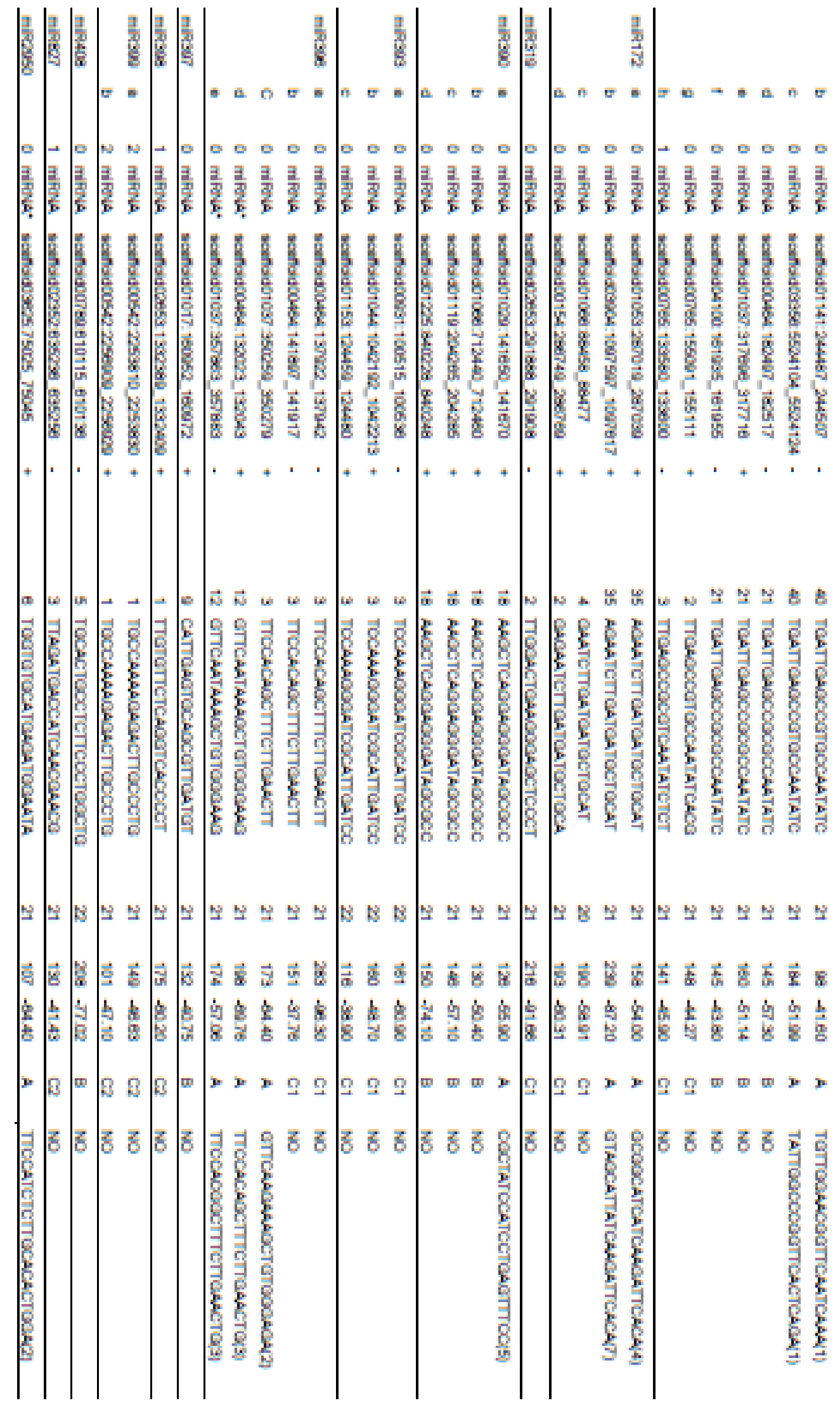


Capitulo V 


\title{
miRNA-mediated regulatory networks affected by Hop stunt viroid infection and prediction of endogenous targets for viroid-derived sRNAs.
}

\author{
Martinez G, Pallás V and Gómez G. \\ Instituto de Biología Molecular y Celular de Plantas, Consejo Superior de \\ Investigaciones Científicas-Universitat Politécnica de València, CPI, Edificio 8 E, Av. \\ Fausto Elio s/n, 46022 Valencia, Spain.
}

\section{To be submitted}

\begin{abstract}
Viroids are plant pathogens with a genome composed by a non-coding RNA, that can potentially trigger a pathogenic response by a cross-talk with the hostendogenous RNA silencing mechanism. This pathogenesis model proposes that viroid-derived sRNAs would silence in trans host mRNAs and hence induce symptoms. Alternatively, plant-symptoms could be a consequence of the alterations caused in the host-endogenous miRNA network by the viroid infection. To go further in the knowledge of the viroid pathogenic process, here we performed an inventory of endogenous sRNAs recovered from HSVd-infected and non-infected cucumber plants, to analyze the potential interference of the viroid infection in the biogenesis and functionality of these small riboregulators. Next, we use bioinformatics to search for potential targets for vd-sRNAs in the cucumber genome.

We observed that the HSVd-infection induces alterations in the cucumber miRNAs map, mainly referred to the processing efficiency and accumulation levels. The HSVd induces a significant decrease in the expression of diverse miRNAs, mainly related to biotic/abiotic stress response. In addition, we observed that the HSVd induces the over expression of five miRNAs, linked to developmental functions and that some miRNA families appear to be specifics of infected tissues. Moreover, a significant number of potential targets for vd-sRNAs were identified in the cucumber transcriptome and predicted to be down-regulated during the infection. The most represented targets were genes involved in developmental processes suggesting that their down-regulation may be related to the symptoms caused by the HSVd infection (stunting, leaf-deformation and flowering-alterations).

In summary, here we demonstrate that two possible scenarios for the interplay between RNA silencing and viroid-induced pathogenesis can exist in cucumber plants: $i$ ) the regulatory miRNAs network affected by HSVd-infection and ii) hostmRNAs susceptible to be silenced by vd-sRNAs.
\end{abstract}




\section{INTRODUCTION}

Non protein-coding RNAs (ncRNAs) constitute an emerging class of riboregulators that are increasingly being involved in the control of gene expression and crucial metabolic pathways in eukaryotic organisms. They comprise a heterogeneous group that fall into several classes based on their length, biogenesis, polarity and functions. According to their size, they have been divided into two different classes: long (>200 nts) and short (<50) ncRNAs. Long non-coding RNAs (lncRNAs), a group poorly studied in plants, have been implicated in the regulation of diverse cellular processes, such as phosphate starvation, nodulation and specific intracellular transport (Campalans et al. 2004; Crespi et al. 1994; Franco-Zorrilla et al. 2007; Gomez and Pallas 2010). In contrast, short non-coding RNAs (sncRNAs) constitute the key components of the RNA silencing phenomenon, a widespread and fundamental regulator of gene expression in eukaryotes (Chen 2009; Ruiz-Ferrer and Voinnet 2009). They arise from a dsRNA precursor processed by an RNase III-like enzyme known as Dicer. In plants, sncRNAs comprise two major groups: micro RNAs (miRNAs) and small interfering RNAs (siRNAs). MiRNAs are endogenous RNAs encoded by genes that despite occupying a small portion of the genome play a pivotal role in the regulation of protein-coding gene expression. They are transcribed, processed and matured in subnuclear compartments and then exported to the cytoplasm where they target mRNAs with homologous sequences (Ruiz-Ferrer and Voinnet 2009). Until now, nearly a thousand miRNA genes have been identified from various plants species (Tang 2010).

According to their evolutionary origin miRNAs can be grouped into two categories: the highly accumulated conserved miRNAs, and the lower accumulated species-specific miRNAs (Cuperus, 2011). While the first class contains mostly the ancient miRNAs that are important in plant development and responses to stress, the latter class might be composed of newly evolved miRNAs with a non-essential function due to their low accumulation. Some miRNAs are induced or repressed by abiotic and biotic stresses (Ruiz-Ferrer and Voinnet 2009; Sanan-Mishra et al. 2009; KatiyarAgarwal and Jin 2010; Lv et al. 2010; Shen et al. 2010; Amin et al. 2011; Frazier et al. 2011; Zhu et al. 2011).

Viroids are non-coding RNAs that infect plants. Their lack of protein-coding capacity makes these pathogenic RNAs strictly dependent of the host factors. 
Consequently, most of their interactions with their hosts biochemical machinery must be mediated by genomic or genome-derived RNAs. Viroids are classified into two families: Pospiviroidae, whose replication takes place in the nucleus, and Avsunviroidae, that replicate (and accumulate) in the chloroplast (Daros et al. 2006; Ding 2009; Flores et al. 2005; Tsagris et al. 2008). The detection of viroid-derived small RNAs (vdsRNAs) in diverse hosts indicates that viroids activate a RNA silencing response in infected plants (Itaya et al. 2001; Papaefthimiou et al. 2001; Martinez de Alba et al. 2002; Markarian et al. 2004; Vogt et al. 2004; Wang et al. 2004; Gomez and Pallas 2007; Carbonell et al. 2008; St-Pierre et al. 2009;). An emergent hypothesis, supported by a large body of evidence, suggests that there is a close interaction between RNA silencing and viroid-induced symptoms. This pathogenicity model proposes that vdsRNA might direct in trans the silencing of physiologically important host mRNAs and hence indirectly, induce the symptom expression (Wang et al., 2004; Gomez et al., 2009; Owens and Hammond 2009). Using microarray analysis, Wang et al (2011) have recently monitored the effects of Potato spindle tuber viroid (PSTVd) infection on the expression levels of $>100$ tomato genes containing potential binding sites for PSTVdderived small RNAs. Remarkably, of 18 such genes down-regulated early in infection, two genes involved in gibberellin or jasmonic acid biosynthesis, contained binding sites for PSTVd derived small RNAs on their respective ORFs. However, the alteration of the plant endogenous miRNAs network induced by viroid replication and processing, can also be considered as an alternative possibility to explain the development of hostsymptoms. Recently, in PSTVd infected plants, Diermann et al (2010) have found that the accumulation of some endogenous miRNAs, which are involved in leaf development via regulation of transcription factors, is supressed, supporting the hypothesis that a miRNA dependent miss-regulation of TFs is caused by viroid infection.

Here we perform an exhaustive inventory of endogenous sRNAs recovered from two different sources (leaves and phloem) of Hop stunt viroid (HSVd)-infected and non-infected Cucumis sativus plants, to analyze the potential interference of a nuclearviroid in the biogenesis and functionality of these small riboregulators. In addition we use a bioinformatic approach to analyze the existence of potential targets in the cucumber genome for HSVd-derived small RNAs, candidates to be regulated in trans during the viroid-infection. 


\section{RESULTS}

\section{Viroid infection alters accumulation profiles of cucumber small RNAs}

To assess if HSVd infection changes the general profiles of host-endogenous sRNAs we compared the size distribution of the total sequence reads from HSVd infected plants with the standards sRNAs levels recently described for cucumber (Martinez et al 2011). As observed in the Figure 1A, $21 \mathrm{nt}$ length sequences showed the highest differential accumulation in infected plants $(>4 \mathrm{x})$, followed by $20 \mathrm{nt}$ size class $(>2 x)$. In contrast, 22 and $24 \mathrm{nt}$ in length classes were the most abundant in mock inoculated cucumber plants. The 23 and $25 \mathrm{nt}$ sequences showed similar accumulation levels in both healthy and HSVd-infected libraries.

To obtain a more detailed picture of the alterations induced by HSVd-infection in the biogenesis pathway of cucumber sRNAs, next we performed a comparative analysis considering the non redundant sequences recovered from both datasets (Figure 1B). In general the variation of the sRNAs profiles were similar to that observed on the total redundant reads with the exception of the $22 \mathrm{nt}$ class that was slightly up-regulated $(\sim 1,3 \mathrm{x})$ in infected plants. These results indicate that in Cucumis sativus plants HSVd infection is associated with a significant alteration of the endogenous sRNAs levels, being $21 \mathrm{nt}$ class the most represented of redundant and non-redundant sequences recovered from infected tissues.

A.

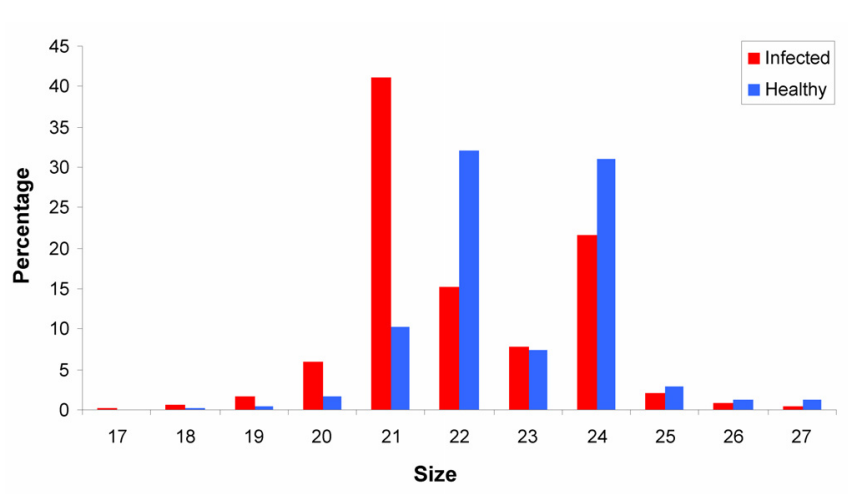

B.

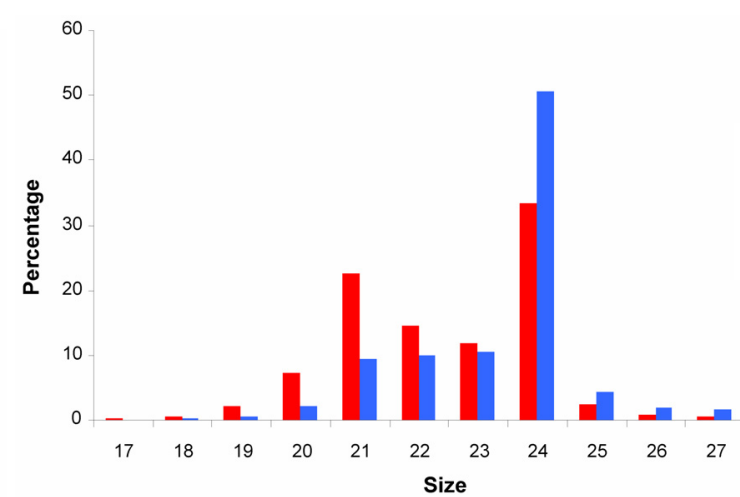

Figure 1. Alteration of sRNAs size distribution dependent of HSVd infection of redundant (A) and nonredundant (B) sRNAs sequences on infected (red bars) and healthy tissues (blue bars). 


\section{HSVd-infection induces differential expression of conserved and non-conserved miRNAs}

In order to clarify if the variation in the profiles of the $21 \mathrm{nt}$ sRNAs observed in the infected plants might be associated with alterations in the biogenesis pathway of endogenous miRNAs induced by the HSVd infection, we analyzed the differential accumulation of cucumber miRNAs in leaves and phloem of infected plants. Although, most of the recently described conserved and non-conserved cucumber miRNAs were recovered from both infected and non-infected libraries, the accumulation ratio of a great number of cucumber miRNAs (taking as significant a 3 fold difference of accumulation) was drastically affected by viroid infection (Figure 2A). A more detailed analysis indicates that the majority (12 out 24) of the miRNAs altered by HSVd were down-regulated whereas only 5 miRNAs were up-regulated in the infected plants.

A.

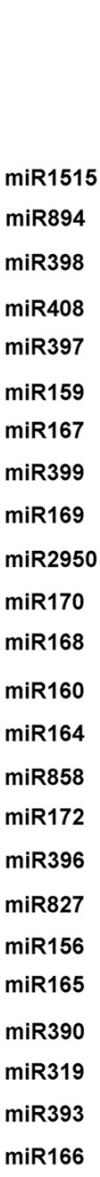

B.

vd-sRNAs

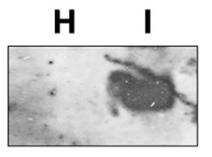

csa-miR398

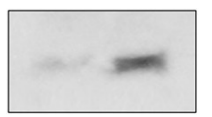

csa-miR167

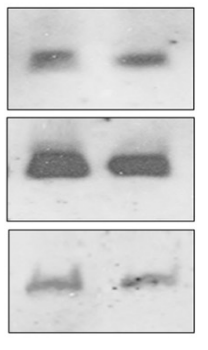

cSa-miR168

csa-miR159

csa-miR172

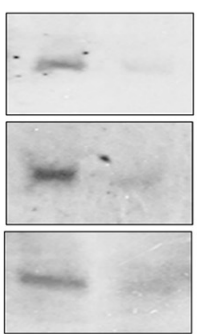

Figure 2. Differential expression of conserved miRNAs during HSVd-infection. A) Histogram of the accumulation ratio (infected/healthy right part, and healthy/infected left part) of conserved miRNAs. B) Northern blot confirmation of over, equally and under-accumulated conserved miRNAs on infected (I) versus healthy $(\mathrm{H})$ tissues. A HSVd probe (vd-sRNAs) was used as a control of infection. 
The comparison of the relative amounts of miRNA families according to the total miRNA accumulation in a specific library revealed that miR166 $\left(25^{\prime} 5 x\right)$, miR393 $\left(19^{\prime} 6 \mathrm{x}\right)$ and miR319 $\left(16^{\prime} 8 \mathrm{x}\right)$ were drastically down-regulated in the HSVd-infected cucumber plants. Interestingly, the down-regulation of the miRNA319 was recently reported in PSTVd-infected tomato plants (Diermann et al. 2010). Lower downregulation levels were observed for the miR390, miR165, miR156, miR827, miR396, miR172, miR858, miR164 and miR160 in infected cucumber plants.

On the other hand, we observed that miR397, miR398, miR408, miR894 and miR1515 were significantly up-regulated in infected tissues. The over expression of miR398 in infected cucumber observed by deep-sequencing was validated by northern blot analysis (Figure 2B). Interestingly, miR398 has also been recently described to be also up-regulated in tomato plants infected with PSTVd (Diermann et al 2010). The remainder cucumber miRNAs showing a differential accumulation rate minor to 3 were considered as similarly recovered from both libraries and classified as non altered by HSVd-infection (Figure 2A). Finally, it was observed an infection-dependent distribution of some $C$. sativus miRNAs. For example miR162, miR394, miR395, miR530, miR1886, miR2111 and miR2916 were found only in infected tissues. In contrast, miR1030 was exclusively found in the library obtained from non-infected plants (Table 1).

In order to identify miRNAS with potential tissue-specific accumulation we individually analyzed the sequences differentially recovered from leaf and phloem of both mock-inoculated and infected cucumber plants. As observed in the supplementary table 1, the miR394, miR395, miR530 and miR1886 were specifically found in HSVdinfected leaves while the miR2111 and miR2916 only were recovered of the phloem of infected cucumber plants. Interestingly miR162 was the unique recovered from both (leaf and phloem) infected tissues. The miR1030 (unique miRNA specific of mockinoculated plants) was found in the library containing sRNAs arising from leaf tissue. 
Table 1. Differential recovering of known miRNAs on infected and healthy tissues. The accumulation of each miRNA is expressed as the percentage of each miRNA from the overall of the miRNAs in the library.

\begin{tabular}{|c|c|c|}
\hline Conserved & Infected & Healthy \\
\hline miR156 & 2,07872326 & 16,1016949 \\
\hline miR159 & 64,0246765 & 29,1525424 \\
\hline miR160 & 0,73090592 & 2,37288136 \\
\hline miR162 & 0,03352779 & 0 \\
\hline $\operatorname{miR} 164$ & 0,33527795 & 1,52542373 \\
\hline $\operatorname{miR} 165$ & 0,00670556 & 0,05649718 \\
\hline miR166 & 0,79796151 & 20,3954802 \\
\hline miR167 & 12,9350231 & 7,34463277 \\
\hline miR168 & 1,63615637 & 4,40677966 \\
\hline $\operatorname{miR} 169$ & 0,44927245 & 0,62146893 \\
\hline $\operatorname{miR172}$ & 0,72420036 & 3,72881356 \\
\hline miR319 & 0,01341112 & 0,2259887 \\
\hline miR390 & 0,227989 & 2,31638418 \\
\hline miR393 & 0,02011668 & 0,39548023 \\
\hline miR394 & 0,00670556 & 0 \\
\hline miR395 & 0,02011668 & 0 \\
\hline miR396 & 0,3419835 & 1,92090395 \\
\hline miR397 & 3,86240193 & 1,01694915 \\
\hline miR398 & 5,77348622 & 0,9039548 \\
\hline miR399 & 0,05364447 & 0,05649718 \\
\hline miR408 & 1,7300342 & 0,4519774 \\
\hline \multicolumn{3}{|c|}{ Non-Conserved } \\
\hline $\operatorname{miR} 170$ & 2,0720177 & 5,19774011 \\
\hline $\operatorname{miR530}$ & 0,02682224 & 0 \\
\hline miR827 & 0,03352779 & 0,2259887 \\
\hline miR858 & 0,12740562 & 0,62146893 \\
\hline miR894 & 0,73761148 & 0,11299435 \\
\hline miR1030 & 0 & 0,05649718 \\
\hline $\operatorname{miR} 1515$ & 0,83819486 & 0,05649718 \\
\hline miR1886 & 0,00670556 & 0 \\
\hline $\operatorname{miR2111}$ & 0,00670556 & 0 \\
\hline miR2916 & 0,02011668 & 0 \\
\hline $\operatorname{miR2950}$ & 0,32857239 & 0,73446328 \\
\hline
\end{tabular}

\section{HSVd induces the differential accumulation of Cucumber specific miRNAs}

Viroid-induced pathogenesis is a specific process dependent of strictly interactions between these pathogenic-RNAs and the biochemical machinery of their hosts. Consequently, it is reasonable to assume that the biogenesis of species-specific miRNAs could be significantly affected during viroid infection. To address this issue we analyzed the accumulation profiles of our previously reported 7 species-specific miRNA candidates (Martínez et al, 2011). As observed in table 2, most of the $C$. sativus-specific miRNAs (csa-Mir1, csa-Mir2, csa-Mir3 and csa-Mir6) were not found in the sRNAs dataset recovered from HSVd-infected plants. On the other hand, csaMir4_1 and csa-Mir4_2 accumulated similarly in both healthy and infected tissues. 
Only csa-Mir 5 increases its accumulation (6-fold) during viroid infection. Intriguingly, following the criteria established for the annotation of new miRNAs, in HSVd-infected plants wue found 2 miRNAs (csa-Mir7 and Csa-Mir8, both with miRNA* strand) and 2 potential miRNAs (csa-Mir 9 and csa-Mir 10) candidates to be cucumber-specific that were not recovered from our previously reported healthy leaf library. In addition, these news miRNAs seem to be tissue specific, since were exclusively recovered from phloem (csa-Mir7 and Csa-Mir8) and leaf (csa-Mir 9 and csa-Mir 10) libraries.

Table 2. Accumulation of previously described miRNAs in Cucumis sativus and novel miRNAs on infected tissues.

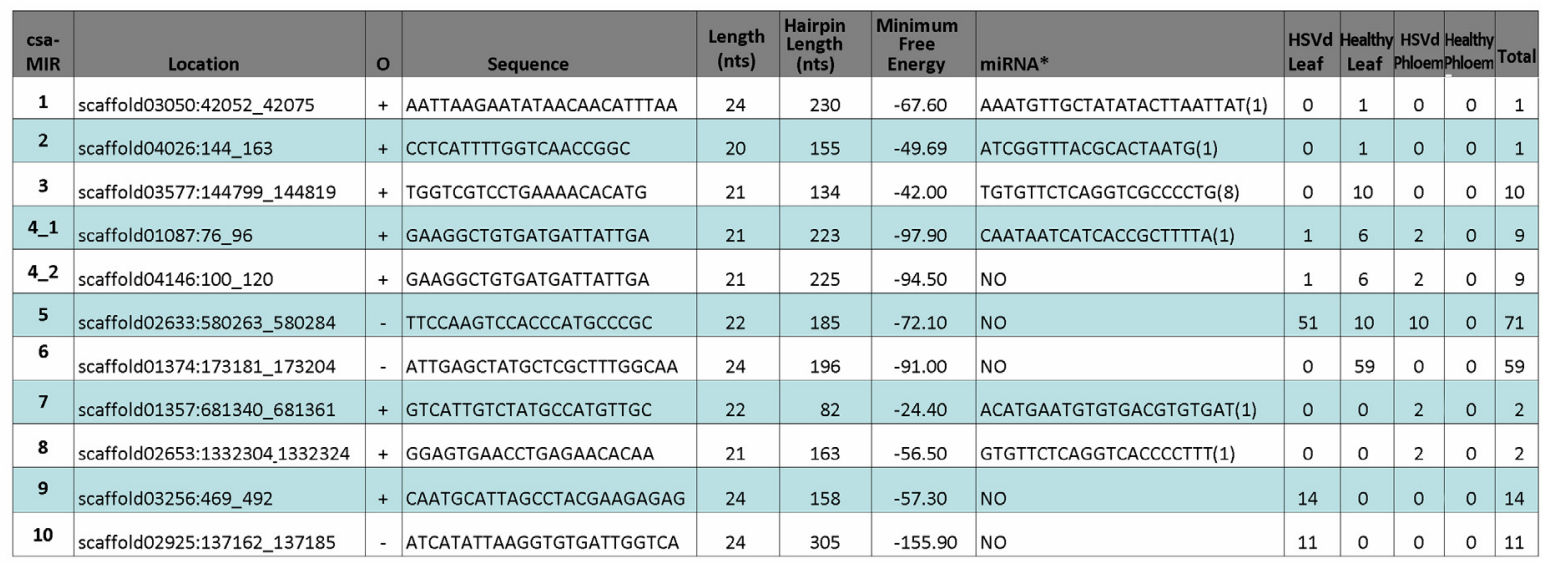

\section{Precision of the miRNA-processing is affected by viroid infection}

The cleavage of plant miRNAs from stem-loop RNA precursors is not a precise process for some miRNA families. Less conserved miRNA families in A. thaliana are processed imprecisely, maybe due to the implication of DCL4 in their biogenesis (Rajagopalan et al. 2006). In order to determine if HSVd infection influences the accuracy of the miRNA processing in $C$. sativus, we analysed the processing precision percentage for each miRNA family defined as the abundance of reads corresponding exactly to the mature miRNA or miRNA* divided by the total abundance of reads mapping to the hairpin (Ma et al. 2010). The obtained results indicate that viroid infection seems to affect dramatically miRNA processing. As observed in figure 3 healthy tissues have a processing precision of 95.45\% (Fig. 3A) while HSVd infection induce the decreasing of this percentage to $80.07 \%$ (Fig. 3B). 
A.

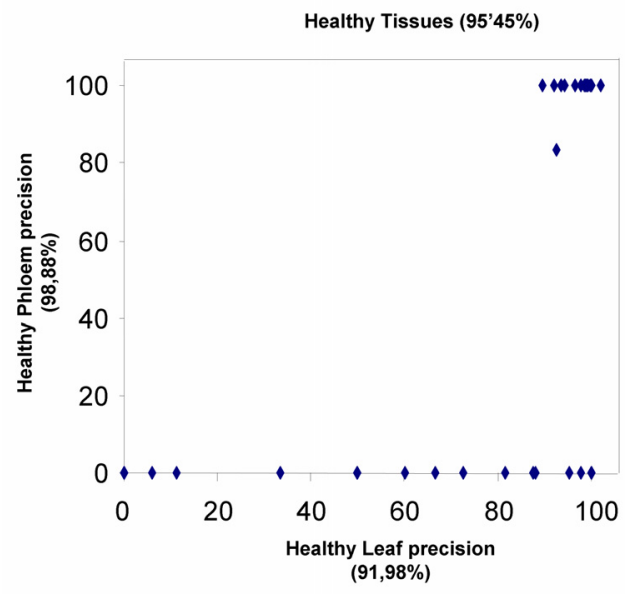

C.

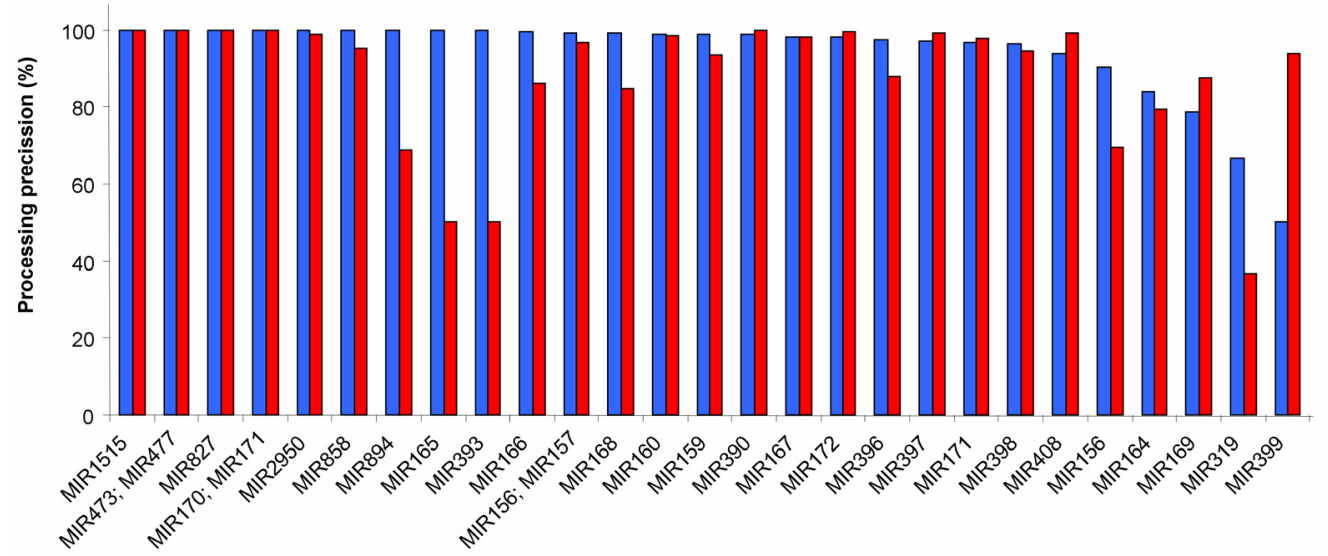

Figure 3. Scatter plot of phloem versus leaf miRNA processing precisions in healthy (A) and infected (B) tissues and histogram $(\mathrm{C})$ of the processing precisions for each miRNA family in healthy tissues (blue bars) and infected tissues (red bars).

This reduction was strongly evident for miR165 and miR393 ( $\sim 50 \%$ of altered processing), miR319 ( 40\%) and miR894 ( 30\%). The opposite situation was observed for miR399 that showed a more acurate processing in infected plants (Figure 3C). In order to analyze if these results were buffered by the tissue origin of the miRNAs, we studied miRNA processing precision within specific tissues. Healthy tissues have the highest precision, 98.88 and $91.98 \%$ (in phloem and leaves respectively), while infected tissues have the lowest percentage, 81.52 and $78.62 \%$ (in infected leaves and phloem) (Figures 3A and 3B).

\section{Potential cucumber targets for vd-sRNAs}

In their cross-talk with a host, pathogens interact with the RNA silencing machinery at two different levels: (1) by promoting the production of sRNAs derived from their genome and (2) by altering the profiles of the endogenous sRNAs (Ruiz- 
Ferrer and Voinnet 2009). The recent sequencing of the Cucumis sativus genome, a HSVd natural host, allowed the bioinformatic prediction of potential host targets for vdsRNAs, similar to that used for endogenous miRNAs (Fahlgren et al. 2007).

We have employed the target finder script developed by the Computational Biology Group of the UEA, included on the online sRNA tools package, to check if the 986 unique vd-sRNAs recovered from HSVd-infected cucumber plants (Martinez et al. 2010) can potentially act as miRNA-like or siRNA-like able to regulate Cucumis sativus gene expression. 334 vd-sRNAs from our set have potential targets on the Cucumis sativus genome, corresponding to 218 different loci. The most abundant size of the vdsRNAs with a predicted target in cucumber is 21-nt followed by 22-nt class, ranging consequently in the canonical size of functional endogenous miRNAs and/or tasi-RNAs. Interestingly these vd-sRNAs have a clear tendency to begin with a $\mathrm{C}(38 \%$ ' $\%), \mathrm{U}$ $\left(31^{\prime} 6 \%\right)$ and $\mathrm{A}\left(15^{\prime} 2 \%\right)$ (Figure 4A). This situation is coincident with previous reports indicating that $\mathrm{AGO}$ proteins exhibit preferred binding affinities for small RNAs having 5' terminal $\mathrm{C}$ (AGO5), $\mathrm{U}$ (AGO1) and $\mathrm{A}$ (AGO2 and AGO4) (Mi et al. 2008; Montgomery et al. 2008; Takeda et al. 2008). Considering the 5' selective loading into AGO complexes of sRNAs, 75 vd-sRNAs could be potentially loaded in AGO1 (involved in the cleavage of target mRNAs or inhibition of mRNA translation), with 203 potential targets and $36 \mathrm{vd}-\mathrm{sRNAs}$ being potentially loaded in AGO4 (involved in DNA methylation and transcriptional gene silencing at specific genomic loci) with 65 predicted targets. As the association of sRNAs to a concrete AGO protein is independent of the sRNA biogenesis pathway (Mi et al. 2008) it is possible that these vd-sRNAs bearing the appropriate 5' sequence may be selectively loaded into active AGO complexes. The analysis of the tissue distribution of the vd-sRNAs was consistent with our previous data (Martinez et al. 2010), since the $22 \mathrm{nt}$ size vd-sRNAs showed preferential accumulation in the phloem (figure 4B), while $21 \mathrm{nt}$ vd-sRNAs accumulate preferentially on leaves (figure 4C).

The identified predicted targets belong to different functional categories. According to the gene ontology categorization for annotated genes in Arabidopsis, the 218 targets in cucumber belong to different biological processes (Figure 5A). The most represented are genes involved in developmental processes, response to biotic and abiotic stimulus, protein metabolism, response to stress and transcription. Among them, the mRNAs with a higher number of targets corresponded to an uncharacterized conserved protein that contains WD40 repeats, a transmembrane amino acid transporter 
protein, an aldehyde dehydrogenase, a transducin family protein / WD-40 repeat family protein and emb2444 gene (Table 3). According to their molecular function, the most represented categories are: kynase activity, transferase activity, nucleotide binding, hydrolase activity, DNA or RNA binding, transcription factor activity and protein binding (Figure 5B). Our analysis suggests that there are an elevated number of transcripts in the cucumber genome that can potentially be targeted by the vd-sRNAs generated during viroid infection. This analysis is the stepping stone to determine the extent of these functional interactions between vd-sRNAs and this identified targets.

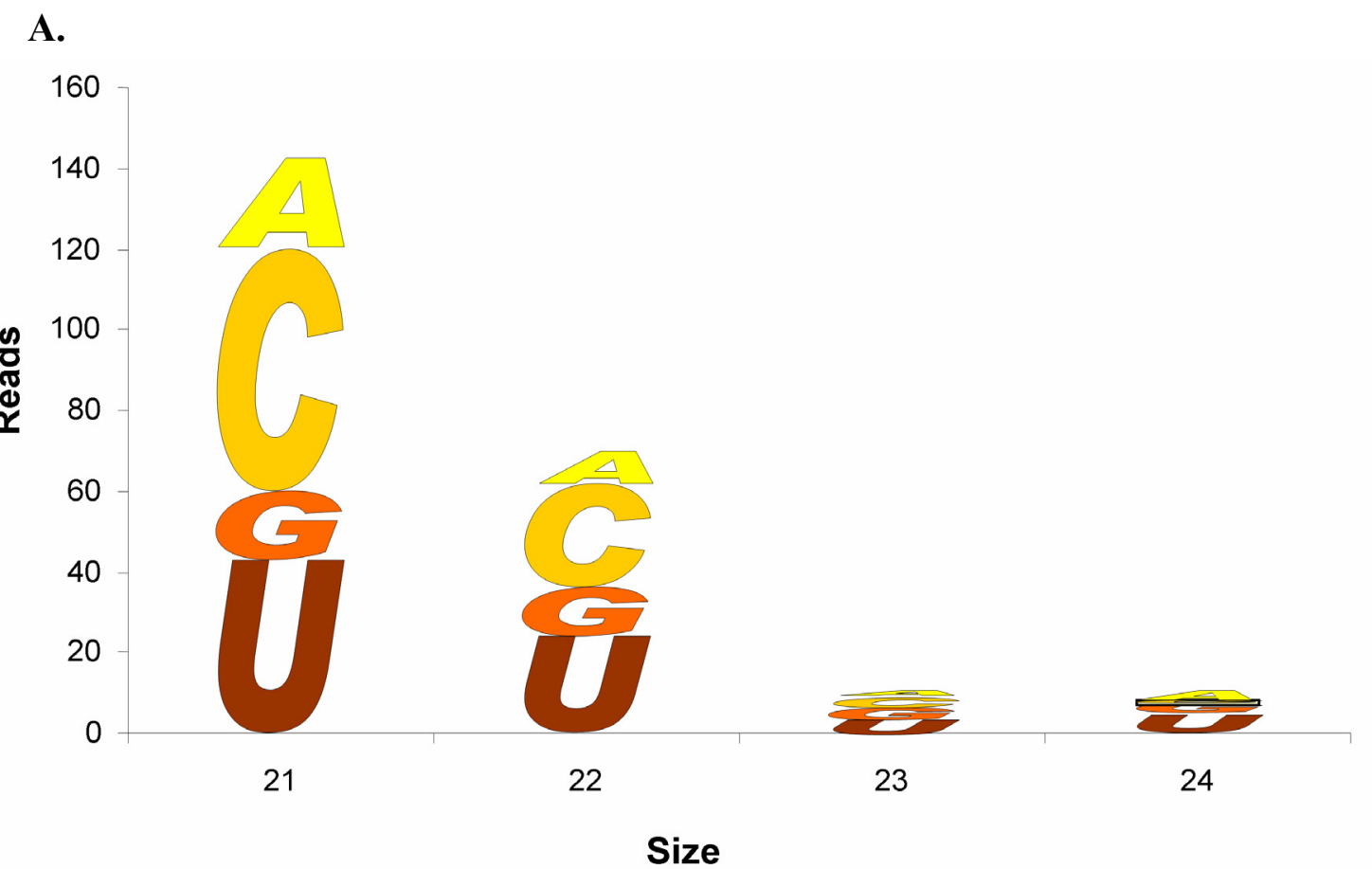

B.

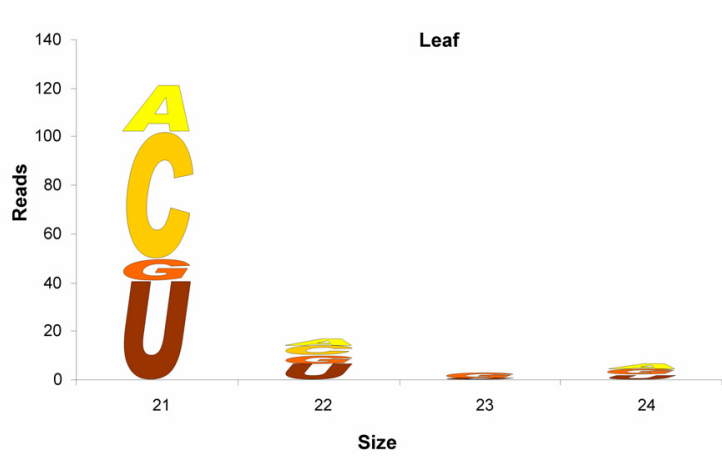

C.

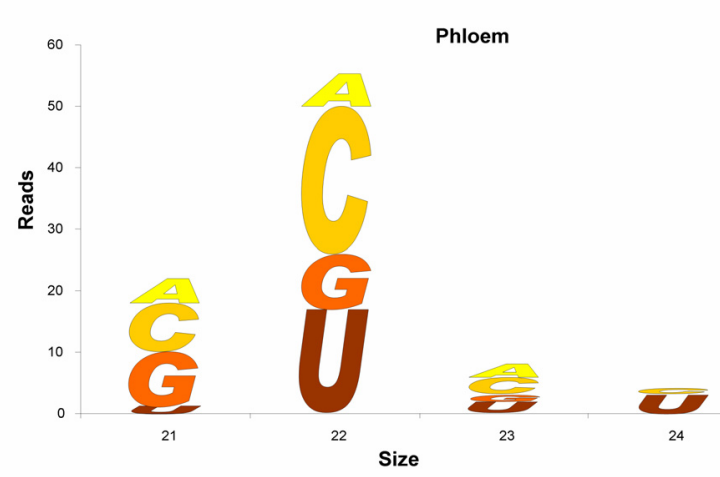

Figure 4. Overall of vd-sRNA with predicted targets accumulation by size and 5'nucleotide (A) and vdsRNA accumulation by library, according to size and 5' nucleotide in (B) leaf and (C)phloem. 
A.

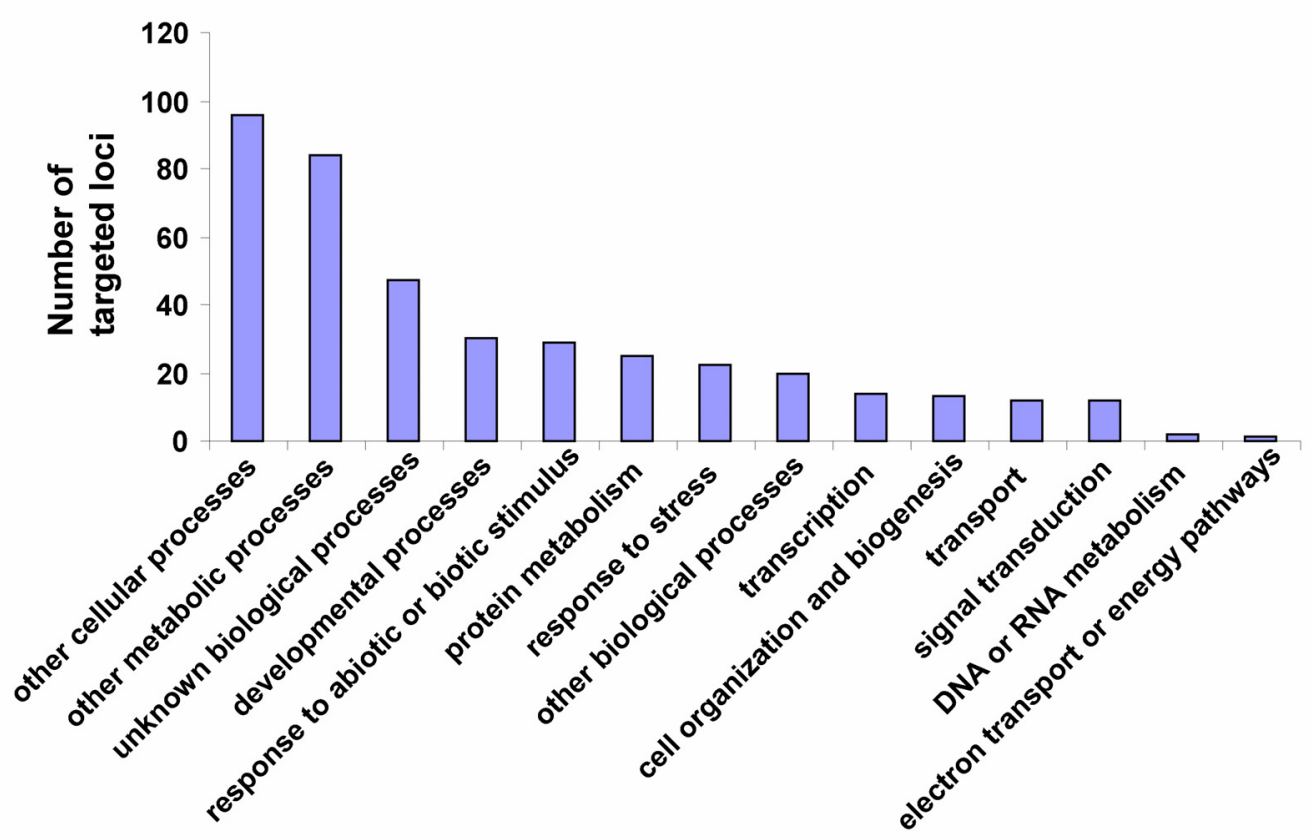

B.

Molecular Function

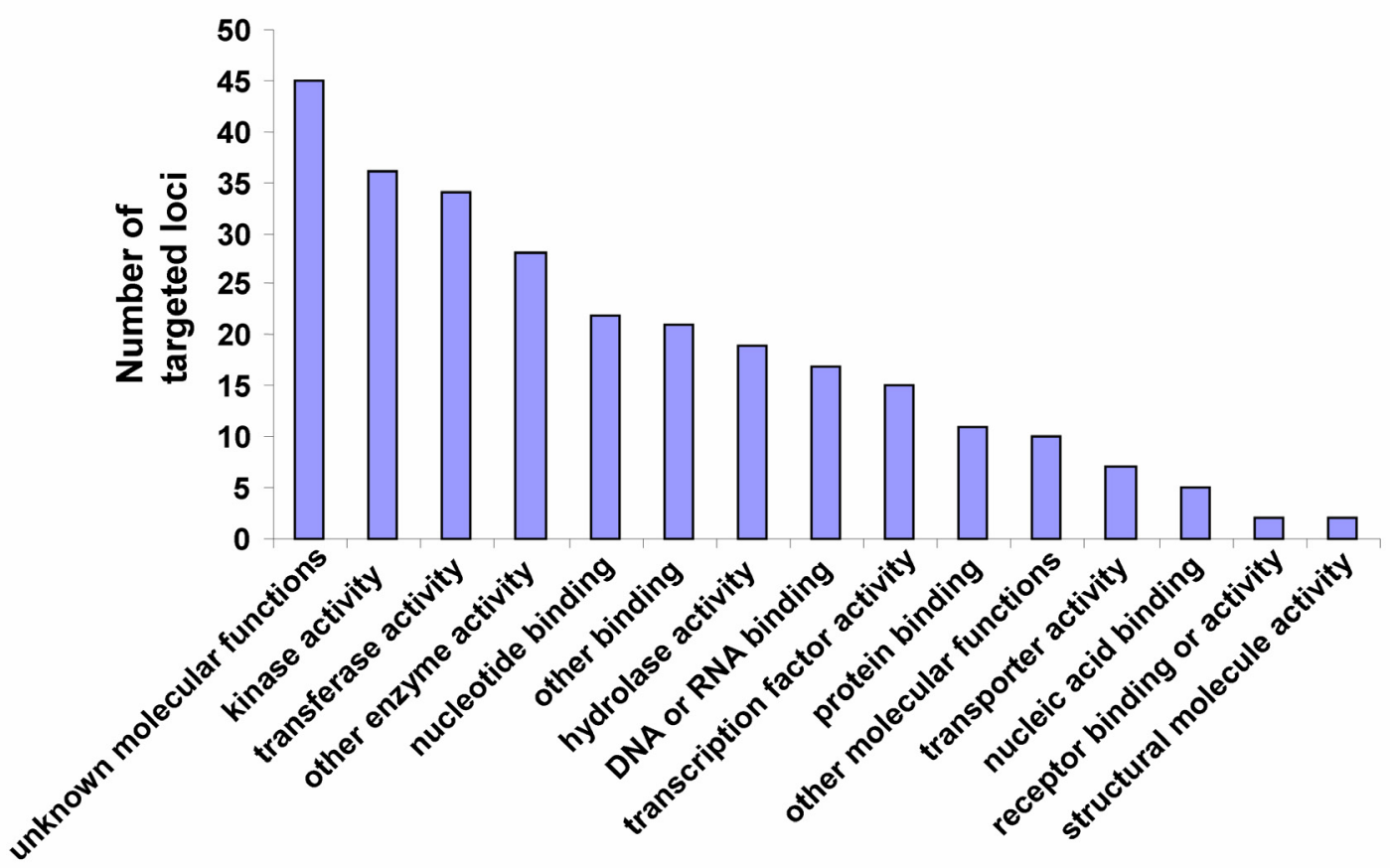

Figure 5. Histogram of the gene ontology of the potential vd-sRNA targets grouped by biological process (A) and molecular function (B). 
Table 3. Description of the vd-sRNA targets with the highest number of different vd-sRNA hits.

\begin{tabular}{|c|c|c|c|}
\hline $\begin{array}{l}\text { Number of } \\
\text { vd-sRNA hits }\end{array}$ & $\begin{array}{l}\text { Target gene } \\
\text { accession }\end{array}$ & Target description & $\begin{array}{l}\text { Arabidopsis } \\
\text { homolog }\end{array}$ \\
\hline 7 & Cucsa.025420.2 & Uncharacterized conserved protein, contains WD40 repeats & No \\
\hline 7 & Cucsa.137530.3 & Transmembrane amino acid transporter protein & No \\
\hline 6 & Cucsa.125400.2 & Aldehyde dehydrogenase & No \\
\hline 5 & Cucsa.192490.1 & transducin family protein / WD-40 repeat family protein & AT4G01860.1 \\
\hline 5 & Cucsa.251850.1 & $\begin{array}{l}\text { emb2444 (embryo defective } 2444 \text { ); } \\
\text { RNA binding / nucleic acid binding / nucleotide binding }\end{array}$ & AT2G18510.1 \\
\hline 5 & Cucsa. 373400.1 & unknown protein & AT3G19895.1 \\
\hline 4 & Cucsa.043800.1 & metal ion binding & AT5G66110.1 \\
\hline 4 & Cucsa.101020.1 & HEC3 (HECATE 3); DNA binding / transcription factor & AT5G09750.1 \\
\hline 4 & Cucsa.144040.4 & $\mathrm{K}+$ potassium transporter & No \\
\hline 4 & Cucsa.254240.1 & PSAD-1 (photosystem I subunit D-1) & AT4G02770.1 \\
\hline 4 & Cucsa.291770.1 & trihelix DNA-binding protein, putative & AT5G28300.1 \\
\hline 4 & Cucsa.339440.1 & bromo-adjacent homology (BAH) domain-containing protein & AT3G48060.1 \\
\hline 3 & Cucsa. 045150.3 & Rhamnogalacturonate lyase family & No \\
\hline 3 & Cucsa.084770.1 & ankyrin repeat family protein & AT5G60070.1 \\
\hline 3 & Cucsa.087450.1 & GRX480; electron carrier/ protein disulfide oxidoreductase & AT1G28480.1 \\
\hline 3 & Cucsa.088520.3 & MEMBRANE PROTEIN CH1 RELATED & No \\
\hline 3 & Cucsa.116150.1 & leucine-rich repeat transmembrane protein kinase, putative & AT2G26730.1 \\
\hline 3 & Cucsa.118530.1 & glyceraldehyde-3-phosphate dehydrogenase & AT1G16300.1 \\
\hline 3 & Cucsa.165300.4 & $\begin{array}{l}\text { GTP-binding protein SEC4, small G protein superfamily, } \\
\text { and related Ras family GTP-binding proteins }\end{array}$ & No \\
\hline 3 & Cucsa.166120.1 & FRO2 (FERRIC REDUCTION OXIDASE 2); ferric-chelate reductase & AT1G01580.1 \\
\hline 3 & Cucsa.179720.1 & ATGSTU19 (GLUTATHIONE S-TRANSFERASE TAU 19) & AT1G78380.1 \\
\hline 3 & Cucsa.193910.4 & ARID/BRIGHT DNA binding domain & No \\
\hline 3 & Cucsa.318530.1 & No anotated & No \\
\hline 3 & Cucsa.321200.4 & VEFS-Box of polycomb protein & No \\
\hline 3 & Cucsa.352470.1 & $\begin{array}{l}\text { CEJ1 (COOPERATIVELY REGULATED BY ETHYLENE } \\
\text { AND JASMONATE 1); DNA binding / transcription factor }\end{array}$ & AT3G50260.1 \\
\hline 3 & Cucsa.358680.1 & PSRP5 (PLASTID-SPECIFIC 50S RIBOSOMAL PROTEIN 5) & AT3G56910.1 \\
\hline 3 & Cucsa.360600.1 & unknown protein & AT1G17665.1 \\
\hline 3 & Cucsa.385350.1 & $\begin{array}{l}\text { PD1 (PREPHENATE DEHYDRATASE 1) } \\
\text { arogenate dehydratase/ prephenate dehydratase }\end{array}$ & AT2G27820.1 \\
\hline
\end{tabular}

\section{DISCUSSION}

The interplay between viroid infection and RNA silencing as a major pathway mediating viroid pathogenesis has been proposed to explain the, still unknown, pathogenic response induced by viroids (Wang, 2004; Gomez, 2008; Gomez, 2009; Owens, 2009). This pathogenesis model is particularly consistent with the infective process induced by members of the Pospiviroidae family, that replicate in the nucleus, 
the cellular compartment where most of the endogenous RNA silencing pathways are carried out (Gomez et al. 2009).

The general picture of the cross-talk between viroid-induced pathogenesis and RNA silencing comprise two different possible scenarios: i) viroid-derived small RNAs might act as endogenous sRNAs to down regulate the expression of host genes and ii) viroid replication in the nucleus could interfere with the biogenesis pathway of endogenous miRNAs involved in the plant development regulation.

To evaluate both fundamental questions in this work we have employed the pathogenic interaction between HSVd (a member of the Pospiviroidae family) and Cucumis sativus (a symptomatic host whose genome has been recently sequenced). First, we analyzed by deep sequencing the influence of the viroid replication and processing in the general profiles of endogenous sRNAs in the infected plant. Next, we search for potential targets of recently sequenced HSVd-specific sRNAs in the cucumber genome, in order to predict host gene candidates to be regulated in trans by viroid-derived small RNAs.

\section{Variations in the miRNA profiles associated with HSVd infection}

The profiling of the endogenous sRNAs recovered from infected plants indicated that the 21-nt length class was the most affected by the HSVd infection. The deregulation of the 21-nt class was observed considering both redundant and non redundant reads, suggesting that viroid-infection alters indistinctly the diversity and the accumulation of this sRNA size class. Keeping in mind that 21-nt is the canonical size of miRNAs and that it has been reported that the profiles of these riboregulators could be altered in response to biotic stress, next we analyzed if the distortion observed for 21-nt class in infected plants could be linked with the modification in the expression level of Cucumis sativus miRNAs. The obtained results indicate that the HSVd infection is associated with a significant unbalance in the expression level of conserved and nonconserved miRNAs in cucumber plants. This general observation although is in contrast with the previous data obtained by northern blot hybridization in CEVd-infected tomato plants (Martin et al. 2007) is consistent with the recent reports (supported by high throughput sequencing) showing that the level of several endogenous miRNAs is altered upon the PSTVd -infection in tomato plants (Diermann et al. 2010).

According to our results, the HSVd induces in the infected cucumber plants a drastic down-regulation of diverse miRNAs. As it is represented in Figure 6, the 
majority of the predicted targets for down-regulated miRNAs are genes involved in plant growth and development such as transcription factors, auxin receptors and tasiRNAs precursors that probably play relevant roles in stress response (Jones-Rhoades and Bartel 2004; Sunkar and Zhu 2004; Zhou et al. 2010). Thus, it is plausible to assume that the decrease of this miRNAs during the viroid infection would induce the over-expression of the corresponding regulatory factors in order to activate genes involved in the plant response to stress induced by pathogens, in a similar way to the observed in rice plants under abiotic stress (Zhou et al. 2010). In this aspect, it is worthy to note that the down-regulation of miR319 induced by a severe strain of PSTVd in tomato was recently reported as associated with the over accumulation of their putative target (the TCP4 mRNA) in infected plants, suggesting a clear interrelation between viroid infection and this miRNA-mediated regulatory pathway (Diermann et al. 2010). Alternatively, these observations allow us to speculate about the existence of possible links between the unbalance of this miRNAs and the physiological alteration induced in the host during the viroid infection. This assumption could be associated with the down regulation of the miRNAs 165/166 observed in the infected cucumber plants. In maize, the adaxial/abaxial (dorsoventral) leaf polarity is established by an abaxial gradient of miR166/miR165, which spatially restricts the expression domain of class III homeodomain leucine zipper (HDZIPIII) transcription factors that specifies adaxial/upper fate (Juarez et al. 2004). Therefore, it is plausible to speculate that the miR166/mir165 down regulation observed during the viroid infection plants might mimic the effects of the (HDZIPIII) gain-of-function mutants and consequently be associated with the leaves development alterations induced by the HSVd in the infected cucumber plants (Fig. 6). Furthermore, the possibility that specific plant regulatory factors dependent of miRNAs activity might be involved in symptoms development was previously postulated to occur in host-virus interactions (Bazzini et al. 2009; Zhang et al. 2006).

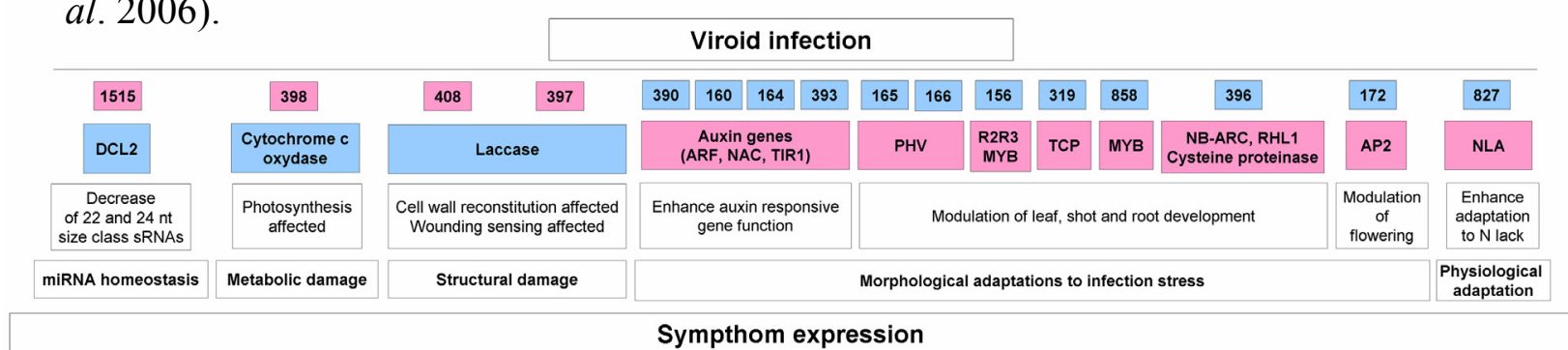

Figure 6. Potential regulatory network of viroid infection-responsive miRNAs in cucumber plants. 
In contrast to the general tendency observed in this work, a reduced group of 5 miRNAs was highly over-represented in the infected plants. According to our results, miR1515 was the most drastically up-regulated miRNA in infected plants. It has been recently demonstrated that the over expression of this miRNA in soybean regulates the expression of a Dicer-like protein which closest Arabidopsis homolog is DCL2. As DCL2 is known to regulate the processing of 22-nt secondary siRNAs involved in endogenous RNA silencing amplification and the biogenesis of the 24-nt natural antisense siRNAs in plants under biotic stresses, it seems reasonable to propose that the over expression of miR1515 associated to HSVd-induced pathogenesis may be responsible of the down-regulation of both 22-nt and 24-nt sRNAs size class observed in infected plants (Figure 1A). MiR398 and miR408 were also up-regulated in HSVdinfected plants. Interestingly, these conserved riboregulators were found to be coordinately over expressed in Medicago truncatula plants in response to water deficit, suggesting the existence of a regulatory link between both miRNAs in the control of the plant response to abiotic stress (Trindade et al. 2010). In addition, have been recently demonstrated that miR398 was also over expressed in tomato plants infected with a lethal PSTVd strain (Diermann et al. 2010). The remainder up regulated miRNAs (miR397 and miR894) has been previously reported to be induced by drought stress in plants (Kantar et al. 2011; Zhou et al. 2010). Remarkably, both miR397 and miR398 it has been recently described as ancient miRNAs acquired in the common ancestors of all spermatophytes (Cuperus et al., 2011).

In coincidence with the observed for conserved miRNAs, most of the $C$. sativusspecific miRNA candidates were also affected during HSVd infection. In our analysis we found a complex scenario with miRNAs specifically recovered from healthy or infected plants and miRNAs up-regulated during the infection. In addition miRNAs associated to infection were specifically recovered from different infected tissues (leaf and phloem), suggesting the existence in cucumber of a complex regulatory network being potentially affected by HSVd infection. Unfortunately, the recently sequenced $C$. sativus genome has not been functionally annotated yet and the targets for speciesspecific miRNAs predicted by bioinformatics approaches remain to be validated. Consequently, we were unable to infer the potential relation between the unbalance of cucumber-specific miRNAs and the pathogenic process induced by HSVd in infected plants. 
Another aspect related to the alteration in the miRNA biogenesis associated to HSVd-infection was, with a few exceptions, the inefficient processing of endogenous miRNAs observed in infected plants. This phenomenon has been associated with the implication of DCL4 in the miRNAs biogenesis (Rajagopalan et al. 2006) and has not been previously reported as induced by other pathogenic RNAs in plants. Although we speculate that the up-regulation of the 21-nt sRNAs observed in the infected plants could be closely related with this inaccurate processing of miRNAs, we cannot currently explain how HSVd could promote this alteration.

In general, the picture emerging of our results supports the idea that in coincidence with the recently reported for PSTVd-infected tomato plants (Diermann et al. 2010), HSVd infection is associated with a significant endogenous-miRNA unbalance in cucumber plants possibly linked to plant-response to disease and/or development alterations currently recognized as symptoms. Further characterization of these affected miRNAs and their potential targets in cucumber will unearth novel features of the interplay between viroid-induced pathogenesis and RNA silencing mechanism.

\section{Potential targets for HSVd-derived sRNAs}

The need to identify potential targets in host genomes that could be regulated in trans by viroid derived sRNAs, is the major criticism to the emerging view that these sRNAs arising from the viroid genome may guide the post-transcriptional silencing of physiologically important host genes and thereby induce disease symptoms. Moreover it still lacks the experimental confirmation of the interaction between vd-sRNAs and host mRNAs that could confirm this hypotesis. Recent indirect demonstration has revealed that of 18 genes down-regulated early in PSTVd-infected tomato plants, two genes involved in giberellin or jasmonic acid biosynthesis contained binding sites for PSTVd derived sRNAs in their respective ORFs (Wang et al. 2011).

Here, we have employed the recently sequenced Cucumis sativus genome and our previously reported vd-sRNAs to predict potential targets. Surprisingly, our results demonstrate that there is a significant number of genes that could be potentially targeted in trans by HSVd-derived sRNAs. Moreover, these vd-sRNAs with a predicted target accumulate all along the viroid genome and not only over the previously reported pathogenic region (figure 7). Nevertheless, it still lacks the confirmation of these vdsRNAs as biologically active in silencing host mRNAs. This preliminary inventory of 
Cucumis sativus transcripts constitute a valuable tool to perform future studies focused in determining their involvement in viroid-induced pathogenesis. Interestingly, the clasification of the Arabidopsis thaliana gene homologs of these potential targets according to their biological functions revealed that the most represented genes are involved in developmental processes.

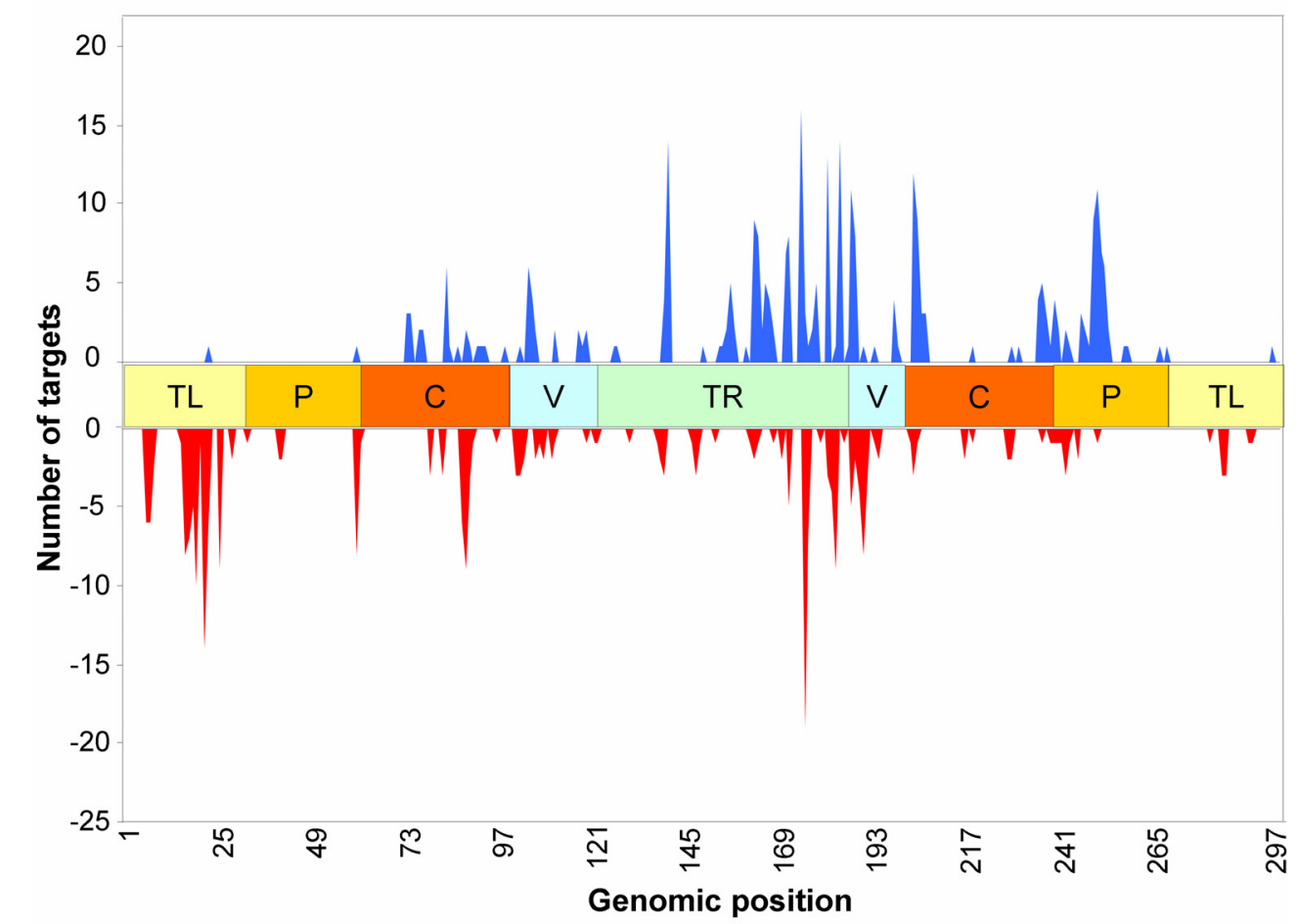

Figure 7. Distribution of positive (blue) and negative (red) polarity HSVd vd-sRNA with a predicted target over HSVd linearized genome.

Consequently, it is plausible to speculate that their down-regulation may be related with the most representative symptoms associated to HSVd infection, stunting, leaf deformation and flowering alterations. Although our results provide evidence consistent with the RNA-silencing mediated pathogenesis model for viroids(Gomez and Pallas 2007; Itaya et al. 2007; Wang et al. 2004), there is still a need to conduct additional analysis to test whether vd-sRNAs indeed silence the expression of any of these potential targets and the contribution of this phenomenon directly to symptom expression (Ding 2009). 


\section{MATERIALS AND METHODS}

\section{Small RNA library information}

The sequences used in this work were obtained from a small RNA library generated starting from a sRNAs population recovered from leaves and phloem exudate of healthy and Hop stunt viroid-infected cucumber (C. sativus) plants and sequenced by 454 Life Science Technology (Lifesequencing, Branfor, CT, USA; www.lifesequencing.com) ((Martinez et al. 2010)-NCBI/SRA accession code SRP001408).

\section{Bioinformatics analysis of sRNA sequences and targets prediction}

Adapter trimming and cleaning of the 454 reads were performed by Perl scripts locally developed by the Bioinformatics Service at the Instituto de Biología Molecular y Celular de Plantas (IBMCP), Valencia, Spain (http://www.ibmcp.upv.es). Next, rRNA, tRNA, snRNA and snoRNA derived sequences were removed from our sRNAs dataset; the remaining sequences were used in this study. The unique sRNA sequences were employed to analyze the sRNAs accumulation profiles and to identify in the miRNA database (miRBase 13.0) known (conserved and non-conserved) miRNAs in cucumber. The sequences ranging the canonical miRNA length \pm 2 nt were considered to be known miRNAs.

To study potential precursor of novel cucumber miRNAs, the sRNA sequences recovered from our library were aligned with $C$. sativus transcript database (http://www.phytozome.net/cucumber.php) and then were processed by miRCat of the small RNA toolkit from the University of East Anglia (http://srnatools.cmp.uea.ac.uk/plant/cgi-bin/srna-tools.cgi). The resulting structures, with minimal matched nucleotide pairs of miRNA and miRNA* exceeding $16 \mathrm{nt}$ and with maximal size differences of miRNA and miRNA* up to $4 \mathrm{nt}$, were retained as new miRNA candidates. The sequences of the targets from C. sativus were searched against the protein database of the NCBI (National Center for Biotechnology Information, http://www.ncbi.nlm.nih.gov/) using the blastx algorithm (translated nucleotide search against protein database).

Our previously reported 986 unique viroid sRNAs (Martinez et al. 2010), were used to search possible targets against the Cucumis sativus transcriptome with the target prediction tool of the small RNA toolkit from the University of East Anglia (http://srna- 
tools.cmp.uea.ac.uk/plant/cgi-bin/srna-tools.cgi). Specifically miRNA/target duplexes must obey the following rules: No more than four mismatches between sRNA \& target (G-U bases count as 0.5 mismatches), no more than two adjacent mismatches in the miRNA/target duplex, no adjacent mismatches in in positions 2-12 of the miRNA/target duplex (5' of miRNA), no mismatches in positions 10-11 of miRNA/target duplex, no more than 2.5 mismatches in positions $1-12$ of the of the miRNA/target duplex ( $5^{\prime}$ of miRNA) and the minimum free energy (MFE) of the miRNA/target duplex should be $>=74 \%$ of the MFE of the miRNA bound to it's perfect complement.

\section{RNA isolation and Northern blot assays}

Cucumber plants were maintained in environmentally controlled growing chambers at two different temperatures $30^{\circ} \mathrm{C}$ and $25^{\circ} \mathrm{C}$, resembling the growing conditions used for sRNAs library generation (16). Total RNA was extracted from leaves using TRI reagent (Sigma, St. Louis, MO, USA) according to the manufacturer's instructions. The low-molecular-weight RNA fraction was enriched using the miRNA Isolation Kit MIRACLE (Stratagene, La Jolla, CA, USA). Low molecular-weight enriched-RNA was loaded onto $20 \%$ polyacrylamide gels with $0.25 \mathrm{x}$ TBE and $8 \mathrm{M}$ urea. RNA was transferred to a nylon membrane (Roche Diagnostics $\mathrm{GmbH}$ ) and crosslinked using 1-Ethyl-3-[3-dimethylaminopropyl] carbodiimide hydrochloride (EDC) as previously described (Pall et al. 2007). Hybridization using different digoxigeninlabelled RNA as a probe was performed as previously described (Gomez and Pallas 2007). 


\section{SUPPLEMENTARY MATERIAL}

Supplementary table 1. Differential recovering of known miRNAs on each library. The accumulation of miRNAs is expressed as the percentage of each miRNA from the overall of the miRNAs in the library.

\begin{tabular}{|c|c|c|c|c|}
\hline Conserved & Infected Leaf & Healthy Leaf & Infected Phloem & Healthy Phloem \\
\hline $\operatorname{miR} 156$ & 2,07 & 16,68 & 2,36 & 1,47 \\
\hline $\operatorname{miR} 159$ & 65,41 & 29,14 & 4,14 & 29,41 \\
\hline $\operatorname{miR} 160$ & 0,59 & 2,41 & 6,8 & 1,47 \\
\hline $\operatorname{miR} 162$ & 0,006 & 0 & 1,18 & 0 \\
\hline $\operatorname{miR} 164$ & 0,32 & 1,29 & 0,59 & 7,35 \\
\hline $\operatorname{miR} 165$ & 0,006 & 0,05 & 0 & 0 \\
\hline $\operatorname{miR} 166$ & 0,58 & 20,62 & 10,05 & 14,70 \\
\hline $\operatorname{miR} 167$ & 12,49 & 7,10 & 31,95 & 13,23 \\
\hline $\operatorname{miR} 168$ & 1,42 & 4,11 & 10,94 & 11,76 \\
\hline $\operatorname{miR} 169$ & 0,35 & 0,64 & 4,43 & 0 \\
\hline $\operatorname{miR} 172$ & 0,53 & 3,81 & 8,87 & 1,47 \\
\hline $\operatorname{miR} 319$ & 0,006 & 0,23 & 0,29 & 0 \\
\hline $\operatorname{miR} 390$ & 0,16 & 2,23 & 2,95 & 4,41 \\
\hline $\operatorname{miR} 393$ & 0,02 & 0,41 & 0 & 0 \\
\hline miR394 & 0,006 & 0 & 0 & 0 \\
\hline $\operatorname{miR} 395$ & 0,02 & 0 & 0 & 0 \\
\hline $\operatorname{miR} 396$ & 0,31 & 1,93 & 1,47 & 1,47 \\
\hline miR397 & 3,95 & 0,99 & 0 & 1,47 \\
\hline $\operatorname{miR} 398$ & 5,71 & 0,76 & 8,28 & 4,41 \\
\hline miR399 & 0,04 & 0,05 & 0,29 & 0 \\
\hline $\operatorname{miR} 408$ & 1,76 & 0,41 & 0,29 & 1,47 \\
\hline \multicolumn{5}{|c|}{ Non-Conserved } \\
\hline $\operatorname{miR} 170$ & 2,12 & 5,4 & 0 & 0 \\
\hline $\operatorname{miR530}$ & 0,02 & 0 & 0 & 0 \\
\hline $\operatorname{miR} 827$ & 0,02 & 0,23 & 0,29 & 0 \\
\hline $\operatorname{miR} 858$ & 0,13 & 0,64 & 0 & 0 \\
\hline miR894 & 0,74 & 0,11 & 0,59 & 0 \\
\hline $\operatorname{miR} 1030$ & 0 & 0,05 & 0 & 0 \\
\hline $\operatorname{miR} 1515$ & 0,85 & 0 & 0 & 1,47 \\
\hline $\operatorname{miR} 1886$ & 0,006 & 0 & 0 & 0 \\
\hline $\operatorname{miR} 2111$ & 0 & 0 & 0,29 & 0 \\
\hline $\operatorname{miR} 2916$ & 0 & 0 & 0,88 & 0 \\
\hline $\operatorname{miR} 2950$ & 0,26 & 0,58 & 2,95 & 4,41 \\
\hline
\end{tabular}




\section{REFERENCES}

Amin, I., Patil, B. L., Briddon, R. W., Mansoor, S., and Fauquet, C. M. (2011), 'A common set of developmental miRNAs are upregulated in Nicotiana benthamiana by diverse begomoviruses', Virology Journal, 8, 143.

Bazzini, A. A., Almasia, N. I., Manacorda, C. A., Mongelli, V. C., Conti, G., Maroniche, G. A., Rodriguez, M. C., Distefano, A. J., Hopp, H. E., del Vas, M., and Asurmendi, S. (2009), 'Virus infection elevates transcriptional activity of miR164a promoter in plants', BMC Plant Biology, 9, 152.

Boss, I. W. and Renne, R. (2010), 'Viral miRNAs: tools for immune evasion', Current Opinion in Microbiology, 13 (4), 540-5.

Campalans, A., Kondorosi, A., and Crespi, M. (2004), 'Enod40, a short open reading frame-containing mRNA, induces cytoplasmic localization of a nuclear RNA binding protein in Medicago truncatula', Plant Cell, 16 (4), 1047-59.

Carbonell, A., Martinez de Alba, A. E., Flores, R., and Gago, S. (2008), 'Doublestranded RNA interferes in a sequence-specific manner with the infection of representative members of the two viroid families', Virology, 371 (1), 44-53.

Crespi, M. D., Jurkevitch, E., Poiret, M., d'Aubenton-Carafa, Y., Petrovics, G., Kondorosi, E., and Kondorosi, A. (1994), 'enod40, a gene expressed during nodule organogenesis, codes for a non-translatable RNA involved in plant growth', EMBO Journal, 13 (21), 5099-112.

Cuperus, J. T., Fahlgren, N., and Carrington, J. C. (2011), 'Evolution and Functional Diversification of MIRNA Genes', Plant Cell, 23 (2), 431-42.

Chen, X. (2009), 'Small RNAs and their roles in plant development', Annual Review of Cell and Developmental Biology, 25, 21-44.

Daros, J. A., Elena, S. F., and Flores, R. (2006), 'Viroids: an Ariadne's thread into the RNA labyrinth', EMBO Reports, 7 (6), 593-8.

Diermann, N., Matousek, J., Junge, M., Riesner, D., and Steger, G. (2010), 'Characterization of plant miRNAs and small RNAs derived from potato spindle tuber viroid (PSTVd) in infected tomato', Biological Chemistry, 391 (12), 137990.

Ding, B. (2009), 'The biology of viroid-host interactions', Annual Review of Phytopathology, 47, 105-31.

Fahlgren, N., Howell, M. D., Kasschau, K. D., Chapman, E. J., Sullivan, C. M., Cumbie, J. S., Givan, S. A., Law, T. F., Grant, S. R., Dangl, J. L., and Carrington, J. C. (2007), 'High-throughput sequencing of Arabidopsis microRNAs: evidence for frequent birth and death of MIRNA genes', Plos One, 2 (2), e219.

Flores, R., Hernandez, C., Martinez de Alba, A. E., Daros, J. A., and Di Serio, F. (2005), 'Viroids and viroid-host interactions', Annual Review of Phytopathology, 43, 117-39.

Franco-Zorrilla, J. M., Valli, A., Todesco, M., Mateos, I., Puga, M. I., Rubio-Somoza, I., Leyva, A., Weigel, D., Garcia, J. A., and Paz-Ares, J. (2007), 'Target mimicry provides a new mechanism for regulation of microRNA activity', Nature Genetics, 39 (8), 1033-7.

Frazier, T. P., Sun, G., Burklew, C. E., and Zhang, B. (2011), 'Salt and Drought Stresses Induce the Aberrant Expression of microRNA Genes in Tobacco', Molecular Biotechnology.

Gomez, G. and Pallas, V. (2007), 'Mature monomeric forms of Hop stunt viroid resist RNA silencing in transgenic plants', Plant Journal, 51 (6), 1041-9. 
Gomez, G. and Pallas, V. (2010), 'Noncoding RNA mediated traffic of foreign mRNA into chloroplasts reveals a novel signaling mechanism in plants', PLoS ONE, 5 (8), e12269.

Gomez, G., Martinez, G., and Pallas, V. (2008), 'Viroid-induced symptoms in Nicotiana benthamiana plants are dependent on RDR6 activity', Plant Physiology, 148 (1), 414-23.

Gomez, G., Martinez, G., and Pallas, V. (2009), 'Interplay between viroid-induced pathogenesis and RNA silencing pathways', Trends in Plant Science, 14 (5), 264-9.

Itaya, A., Folimonov, A., Matsuda, Y., Nelson, R. S., and Ding, B. (2001), 'Potato spindle tuber viroid as inducer of RNA silencing in infected tomato', Molecular Plant-Microbe Interactions, 14 (11), 1332-4.

Itaya, A., Zhong, X., Bundschuh, R., Qi, Y., Wang, Y., Takeda, R., Harris, A. R., Molina, C., Nelson, R. S., and Ding, B. (2007), 'A structured viroid RNA serves as a substrate for dicer-like cleavage to produce biologically active small RNAs but is resistant to RNA-induced silencing complex-mediated degradation', J Virol, 81 (6), 2980-94.

Jones-Rhoades, M. W. and Bartel, D. P. (2004), 'Computational identification of plant microRNAs and their targets, including a stress-induced miRNA', Molecular Cell, 14 (6), 787-99.

Juarez, M. T., Kui, J. S., Thomas, J., Heller, B. A., and Timmermans, M. C. (2004), 'microRNA-mediated repression of rolled leafl specifies maize leaf polarity', Nature, 428 (6978), 84-8.

Kantar, M., Lucas, S. J., and Budak, H. (2011), 'miRNA expression patterns of Triticum dicoccoides in response to shock drought stress', Planta, 233 (3), 471-84.

Katiyar-Agarwal, S. and Jin, H. (2010), 'Role of small RNAs in host-microbe interactions', Annual Review of Phytopathology, 48, 225-46.

Lv, D. K., Bai, X., Li, Y., Ding, X. D., Ge, Y., Cai, H., Ji, W., Wu, N., and Zhu, Y. M. (2010), 'Profiling of cold-stress-responsive miRNAs in rice by microarrays', Gene, 459 (1-2), 39-47.

Ma, Z., Coruh, C., and Axtell, M. J. (2010), 'Arabidopsis lyrata small RNAs: transient MIRNA and small interfering RNA loci within the Arabidopsis genus', Plant Cell, 22 (4), 1090-103.

Markarian, N., Li, H. W., Ding, S. W., and Semancik, J. S. (2004), 'RNA silencing as related to viroid induced symptom expression', Archives of Virology, 149 (2), 397-406.

Martin, R., Arenas, C., Daros, J. A., Covarrubias, A., Reyes, J. L., and Chua, N. H. (2007), 'Characterization of small RNAs derived from Citrus exocortis viroid (CEVd) in infected tomato plants', Virology, 367 (1), 135-46.

Martinez de Alba, A. E., Flores, R., and Hernandez, C. (2002), 'Two chloroplastic viroids induce the accumulation of small RNAs associated with posttranscriptional gene silencing', Journal of Virology, 76 (24), 13094-96.

Martinez, G., Donaire, L., Llave, C., Pallas, V., and Gomez, G. (2010), 'Highthroughput sequencing of Hop stunt viroid-derived small RNAs from cucumber leaves and phloem', Mol Plant Pathol, 11 (3), 347-59.

Mi, S., Cai, T., Hu, Y., Chen, Y., Hodges, E., Ni, F., Wu, L., Li, S., Zhou, H., Long, C., Chen, S., Hannon, G. J., and Qi, Y. (2008), 'Sorting of small RNAs into Arabidopsis argonaute complexes is directed by the 5' terminal nucleotide', Cell, $133(1), 116-27$. 
Montgomery, T. A., Howell, M. D., Cuperus, J. T., Li, D., Hansen, J. E., Alexander, A. L., Chapman, E. J., Fahlgren, N., Allen, E., and Carrington, J. C. (2008), 'Specificity of ARGONAUTE7-miR390 interaction and dual functionality in TAS3 trans-acting siRNA formation', Cell, 133 (1), 128-41.

Owens, R. A. and Hammond R.W. (2009). 'Viroid Pathogenicity: One Process, Many Faces. ' Viruses-Basel 1(2): 298-316.

Pall, G. S., Codony-Servat, C., Byrne, J., Ritchie, L., and Hamilton, A. (2007), 'Carbodiimide-mediated cross-linking of RNA to nylon membranes improves the detection of siRNA, miRNA and piRNA by northern blot', Nucleic Acids Research, 35 (8), e60.

Papaefthimiou, I., Hamilton, A., Denti, M., Baulcombe, D., Tsagris, M., and Tabler, M. (2001), 'Replicating potato spindle tuber viroid RNA is accompanied by short RNA fragments that are characteristic of post-transcriptional gene silencing', Nucleic Acids Res, 29 (11), 2395-400.

Rajagopalan, R., Vaucheret, H., Trejo, J., and Bartel, D. P. (2006), 'A diverse and evolutionarily fluid set of microRNAs in Arabidopsis thaliana', Genes \& Development, 20 (24), 3407-25.

Ruiz-Ferrer, V. and Voinnet, O. (2009), 'Roles of plant small RNAs in biotic stress responses', Annu Rev Plant Biol, 60, 485-510.

Sanan-Mishra, N., Kumar, V., Sopory, S. K., and Mukherjee, S. K. (2009), 'Cloning and validation of novel miRNA from basmati rice indicates cross talk between abiotic and biotic stresses', Molecular Genetics and Genomics, 282 (5), 463-74.

Shen, J., Xie, K., and Xiong, L. (2010), 'Global expression profiling of rice microRNAs by one-tube stem-loop reverse transcription quantitative PCR revealed important roles of microRNAs in abiotic stress responses', Molecular Genetics and Genomics, 284 (6), 477-88.

St-Pierre, P., Hassen, I. F., Thompson, D., and Perreault, J. P. (2009), 'Characterization of the siRNAs associated with peach latent mosaic viroid infection', Virology, 383 (2), 178-82.

Sunkar, R. and Zhu, J. K. (2004), 'Novel and stress-regulated microRNAs and other small RNAs from Arabidopsis', Plant Cell, 16 (8), 2001-19.

Takeda, A., Iwasaki, S., Watanabe, T., Utsumi, M., and Watanabe, Y. (2008), 'The mechanism selecting the guide strand from small RNA duplexes is different among argonaute proteins', Plant and Cell Physiology, 49 (4), 493-500.

Tang, G. (2010), 'Plant microRNAs: an insight into their gene structures and evolution', Seminars in Cell \& Developmental Biology, 21 (8), 782-9.

Trindade, I., Capitao, C., Dalmay, T., Fevereiro, M. P., and Santos, D. M. (2010), 'miR398 and miR408 are up-regulated in response to water deficit in Medicago truncatula', Planta, 231 (3), 705-16.

Tsagris, E. M., Martinez de Alba, A. E., Gozmanova, M., and Kalantidis, K. (2008), 'Viroids', Cellular Microbiology, 10 (11), 2168-79.

Vogt, U., Pelissier, T., Putz, A., Razvi, F., Fischer, R., and Wassenegger, M. (2004), 'Viroid-induced RNA silencing of GFP-viroid fusion transgenes does not induce extensive spreading of methylation or transitive silencing', Plant J, 38 (1), 10718.

Wang, M. B., Bian, X. Y., Wu, L. M., Liu, L. X., Smith, N. A., Isenegger, D., Wu, R. M., Masuta, C., Vance, V. B., Watson, J. M., Rezaian, A., Dennis, E. S., and Waterhouse, P. M. (2004), 'On the role of RNA silencing in the pathogenicity and evolution of viroids and viral satellites', Proc Natl Acad Sci U S A, 101 (9), 3275-80. 
Wang Y, Shibuya M, Taneda A, Kurauchi T, Senda M, Owens RA and Sano T (2011). 'Accumulation of Potato spindle tuber viroid-specific small RNAs is accompanied by specific changes in gene expression in two tomato cultivars', Virology, 413(1):72-83.

Zhang, X., Yuan, Y. R., Pei, Y., Lin, S. S., Tuschl, T., Patel, D. J., and Chua, N. H. (2006), 'Cucumber mosaic virus-encoded 2b suppressor inhibits Arabidopsis Argonaute1 cleavage activity to counter plant defense', Genes \& Development, 20 (23), 3255-68.

Zhou, L., Liu, Y., Liu, Z., Kong, D., Duan, M., and Luo, L. (2010), 'Genome-wide identification and analysis of drought-responsive microRNAs in Oryza sativa', Journal of Experimental Botany, 61 (15), 4157-68.

Zhu, C., Ding, Y., and Liu, H. (2011), 'MiR398 and plant stress responses', Physiologia Plantarum. 142: no. doi: 10.1111/j.1399-3054.2011.01477. 


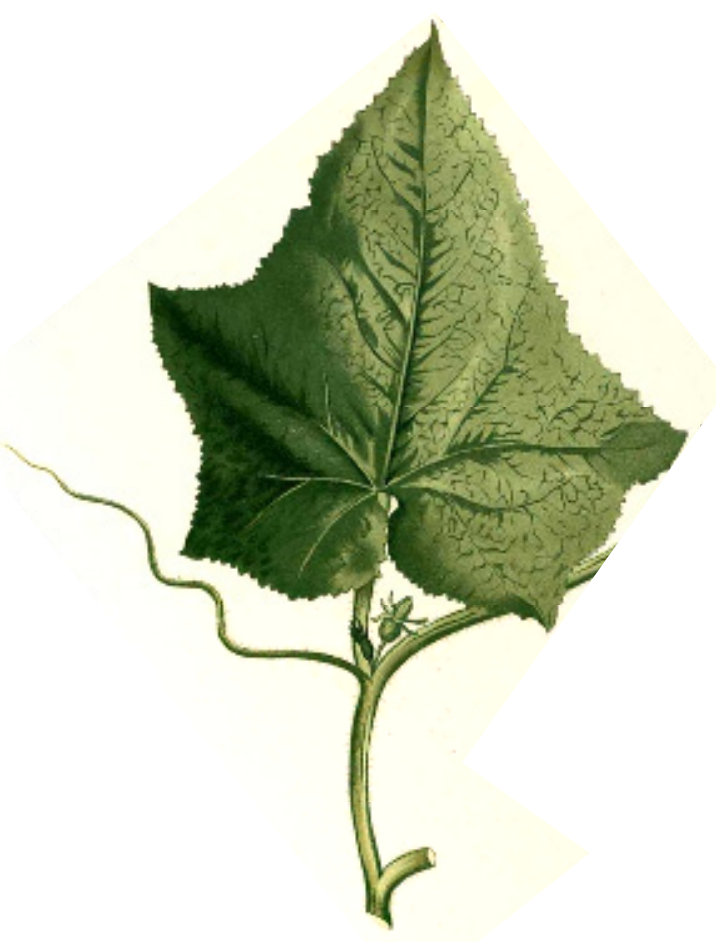

Discusión general 


\section{La patogénesis viroidal. Antecedentes}

Los viroides son patógenos de plantas con una baja complejidad biológica capaces de infectar un gran numero de especies vegetales (tanto herbáceas como leñosas). Aparte del interés agroeconómico que pueden aportar, los viroides constituyen el modelo más simple para estudiar las interacciones entre patógenos de RNA y sus huéspedes (Ding y Itaya, 2007).

Los viroides no poseen capacidad descrita para codificar proteínas, por lo tanto, todas las fases de su ciclo vital así como la respuesta patogénica inducida durante su infección son estrictamente dependientes de su interacción con factores del huésped.

La visión clásica del proceso de patogénesis viroidal asume que las alteraciones inducidas en la planta durante la infección son consecuencia de la competencia huéspedpatógeno por factores celulares implicados en la trascripción, el movimiento célula a célula y/o el movimiento sistémico del viroide. Si esta fuera la principal causa del proceso patogénico cabría esperar una relación directa entre el título del viroide y la gravedad de la sintomatología y este no es el caso (Tabler y Tsagris, 2004; Flores et al., 2005; Owens y Hammond, 2009). Es por ello que la inducción o represión de genes endógenos de la planta tanto a nivel transcripcional como post-transcripcional, $\mathrm{o}$ modificaciones traduccionales de los productos génicos por la interacción entre el RNA viroidal y su huésped emergen como algunas de las posibles causas de las alteraciones bioquímicas inducidas en el huésped durante la patogénesis viroidal (Conejero, 2003; Ding, 2009; Owens y Hammond, 2009). Además, una serie de resultados obtenidos en estudios previos sugieren que posiblemente la respuesta de silenciamiento de RNA del huésped frente a estos patógenos sea la responsable del proceso de patogénesis asociado con la infección viroidal (Wang et al., 2004).

El silenciamiento de RNA es un mecanismo de regulación de la expresión génica conservado en eucariotas, implicado en procesos fundamentales tales como el mantenimiento de la integridad del genoma, la regulación del desarrollo o la defensa frente a patógenos (Ruiz-Ferrer y Voinnet, 2009). Existen distintas rutas de silenciamiento de RNA en plantas y todas constan de 4 pasos conservados: 1) inducción del silenciamiento por un RNA de doble cadena (dsRNA), 2) procesamiento de dicho dsRNA en moléculas de sRNAs de entre 18 y 25 nucleótidos (nt), 3) metilación 2'-O del sRNA y finalmente 4) incorporación en el complejo efector que se asocia con un RNA o DNA con una homología total o parcial (Ruiz-Ferrer y Voinnet, 2009). 
En general, la interacción planta-patógeno activa la maquinaria del silenciamiento de RNA a dos niveles: 1) mediante la producción de sRNAs derivados del genoma del patógeno y 2) modificando el patrón de sRNAs celulares causando la modificación de la expresión de reguladores o efectores de las rutas de defensa del hospedador (Ruiz-Ferrer y Voinnet, 2009).

Diversos trabajos indican que los viroides acumulan sRNAs derivados de su genoma de entre 20 y 25 nts (Itaya et al., 2001; Papaefthimiou et al., 2001; Martinez de Alba et al., 2002; Markarian et al., 2004; Gomez y Pallas, 2007; Martin et al., 2007; StPierre et al., 2009). Esta es la evidencia inequívoca de que los viroides interaccionan con la maquinaria de silenciamiento en alguna medida y es una evidencia indirecta de la acción de DCL sobre los viroides. Además, estos vd-sRNAs tienen un grupo fosfato en su extremo 5' (evidencia de la acción de las enzimas Dicer-Like [DCL]) y están metilados en su extremo 3' (Martin et al., 2007). No obstante, se desconocen cuales son los actores de la maquinaria de silenciamiento responsables de la biogénesis de vdsRNAs, así como las formas biológicas del viroide de las cuales derivan.

Los estudios directos (secuenciación) de vd-sRNAs realizados a fecha del inicio de esta tesis doctoral arrojaban datos confusos sobre los componentes y los precursores implicados en su biogénesis, generando en consecuencia explicaciones contradictorias. Para los viroides miembros de la familia Pospiviroidae (objeto de estudio en la presente tesis doctoral), las moléculas maduras del viroide podrían actuar como sustratos de DCL4/DCL2 para dar lugar a vd-sRNAs primarios en su tránsito por el citoplasma. Pero también los intermediarios replicativos o la molécula madura podrían dar lugar a estos vd-sRNAs en el núcleo por la acción de DCL1. También podría ocurrir que los vdsRNAs primarios sirvieran como cebadores para, a partir de los intermediarios replicativos de simple cadena, ser amplificados en el citoplasma por la RNA polimerasa dependiente de RNA 6 (RDR6) generando dsRNAs que servirían como sustratos para DCLs citoplásmicas.

Según nuestra visión, este inmenso cúmulo de incógnitas ponía de manifiesto la necesidad de realizar un profundo estudio sobre la naturaleza de las relaciones existentes entre el ciclo biológico de los viroides nucleares y la maquinaria de silenciamiento de RNA del huésped, con el objetivo de identificar los posibles precursores de los sRNAs derivados del viroide así como las enzimas implicadas en su procesamiento y tratar de definir las relaciones existentes entre el proceso de 
patogénesis inducido por estos RNAs y la maquinaria de silenciamiento de RNA endógena de la planta.

\section{Búsqueda de un modelo para el estudio de la interacción patogénesis- silenciamiento de RNA.}

Un organismo modelo es aquel que sirve como elemento de estudio de fenómenos biológicos que son difíciles de estudiar directamente en otros organismos. Esto es posible debido al parentesco existente entre todos los organismos, y a la conservación durante el proceso evolutivo de rutas de desarrollo, rutas metabólicas y material genético. Algunas de las características preferentes al escoger un organismo modelo son: facilidad de manipulación experimental, ciclo vital corto y fácil manipulación genética (Muller y Grossniklaus, 2010). En biología molecular de plantas el organismo modelo por excelencia es Arabidopsis thaliana debido a su pequeño tamaño, corto ciclo de vida, reducido genoma y facilidad de trabajo (Pang y Meyerowitz, 1987). No obstante, en virología de plantas el sistema modelo más utilizado ha sido Nicotiana benthamiana debido a que es huésped potencial de un gran numero de virus de plantas (Goodin et al., 2008). Además, es un modelo atractivo para el estudio de silenciamiento masivo de RNA (Lu et al., 2003), expresión transitoria de proteínas fluorescentes por agroinfiltración (Bendahmane et al., 2000; Goodin et al., 2002; Escobar et al., 2003) y estudios de genómica funcional (Senthil et al., 2005).

La mayoría de componentes de la maquinaria de silenciamiento de RNA se han identificado por genética reversa en Arabidopsis thaliana (Eamens et al., 2008). Para el mejor estudio de las funciones de algunos de ellos se han realizado mutantes en Nicotiana benthamiana, como es el caso del mutante silenciado para la expresión de la RDR6. Desafortunadamente, ni A.thaliana ni $N$. benthamiana se encuentran dentro de la gama de huéspedes naturales o experimentales que infectan los viroides, por lo que era necesaria la implementación de estrategias alternativas para su estudio. En este sentido la generación de modelos transgénicos emergía como la opción mas adecuada.

Teniendo en cuenta que en estudios previos se había demostrado la incapacidad de inducir una infección sistémica por viroides miembros de la familia Pospiviroidae mediante transgénesis en Arabidopsis (Daros y Flores, 2004), se optó en nuestro laboratorio por generar un modelo transgénico $\mathrm{HSVd} / N$. benthamiana en el que oportunamente se demostró que las formas biológicas del viroide eran correctamente procesadas y transportadas sistémicamente a través de injertos (Gomez y Pallas, 2006). 
HSVd es un viroide miembro de la familia Pospiviroidae descrito en una amplia gama de huéspedes (al menos 5 familias: Cannobaceae, Rosaceae, Rutaceae, Vitaceae and Cucurbitaceae). Infecta de manera latente algunos de estos huéspedes como vid (Shikata, 1990; Polivka et al., 1996), albaricoquero (Astruc et al., 1996) y almendro (Cañizares et al., 1999). En otras especies se ha asociado la infección por HSVd con desordenes específicos como enanismo en lúpulo (Shikata, 1990), el manchado de la fruta en melocotonero y ciruelo (Sano et al., 1989) y cachexia en cítricos (Diener et al., 1988; Semancik et al., 1988).

Si bien se había demostrado que en $N$. benthamiana el viroide era capaz de inducir infección sistémica mediada por transgénesis (Gomez y Pallas, 2006), no existía un conocimiento detallado de las alteraciones fenotípicas (síntomas) inducidas por HSVd en este sistema modelo lo que condicionaba su potencial uso para el estudio de las relaciones entre silenciamiento de RNA y expresión de síntomas.

Por esta razón se determinó como primer objetivo de esta tesis el caracterizar las alteraciones en el desarrollo inducidas por $\mathrm{HSVd}$ en plantas transgénicas de $N$. benthamiana. De forma general, el análisis de las alteraciones fenotípicas en plantas de $N$. benthamiana que expresaban formas diméricas de HSVd confirmó su similitud con los síntomas asociados a la infección del viroide en sus huéspedes naturales. Estas líneas, mostraban una disminución clara del tamaño ( $70 \%$ del control de transformación), acortamiento de los entrenudos, retardo de la floración ( 7 días), severa disminución en el número $(\sim 45 \%)$ y tamaño de las flores $(\sim 19 \%)$ (Martínez et al., 2008, Capítulo I). Estas afecciones en la floración causaban además aborto de los frutos antes de la madurez, disminución de la producción de semillas y un moderado nivel de infertilidad. Todas estas alteraciones en el desarrollo coincidían con las previamente descritas para el HSVd en sus huéspedes naturales, disminución del tamaño (Shikata, 1990), reducción del tamaño de las flores (Sano, 2003) y las deficiencias en la calidad del fruto y la viabilidad de las semillas (Singh, 2003). Esta observación nos permitió determinar que en nuestro sistema modelo el HSVd reproduce, al menos a nivel fenotípico, los desordenes observados en una infección convencional lo que permite emplear el sistema HSVd/Nicotiana benthamiana como modelo para el estudio del proceso de patogénesis inducido por los viroides nucleares. 


\section{La patogénesis viroidal es dependiente de RDR6 en Nicotiana benthamiana.}

Uno de las visiones más atractivas acerca del proceso de patogénesis asociado a infecciones viroidales liga este fenómeno con la respuesta de silenciamiento de RNA inducida por estos patógenos en el huésped (Wang et al., 2004). Esta idea es consistente con la observación de que algunos viroides acumulan sRNAs derivados de sus genomas de forma correlativa a la gravedad de sus síntomas (Itaya et al., 2001; Papaefthimiou et al., 2001; Denti et al., 2004; Markarian et al., 2004; Matousek et al., 2007). No obstante, en otras combinaciones no se ha descrito una clara correlación entre intensidad de síntomas y acumulación de vd-sRNAs (Itaya et al., 2001; Papaefthimiou et al., 2001; Martinez de Alba et al., 2002; Markarian et al., 2004; Vogt et al., 2004; Matousek et al., 2007). Al contrario de lo que ocurre en virus la acumulación de vd-sRNAs no impide a los viroides acumularse en altas cantidades (Itaya et al., 2001). Esto puede relacionarse con su alta tasa de replicación, una compartimentalizacion en orgánulos celulares aislados de la maquinaria de silenciamiento o por asociación con proteínas del huésped (Chang et al., 2003; Vogt et al., 2004; Flores et al., 2005). No obstante, este hecho junto con la incapacidad de los viroides de codificar proteínas supresoras del silenciamiento ha llevado a varios grupos (Wang et al., 2004; Gomez y Pallas, 2007; Itaya et al., 2007) a considerar la hipótesis de que la estructura secundaria del viroide sería responsable de su resistencia a la degradación, al igual que ocurre con ciertos virus animales (Gitlin et al., 2005; Westerhout et al., 2005). La resistencia de los viroides al silenciamiento podría explicarse por dos motivos: 1) los vd-sRNAs no son funcionales silenciando al propio viroide o 2) el viroide es susceptible al corte por DCLs pero resistente a la degradación por RISC (Ding, 2009; Owens y Hammond, 2009).

Los datos en ambos sentidos parecen de nuevo contradictorios. Se ha demostrado que vd-sRNAs derivados de PSTVd son activos en la degradación de secuencias de RNA introducidas artificialmente con secuencias diana para esos vdsRNAs (Vogt et al., 2004). Además, secuencias derivadas de PSTVd simulan la sintomatología de una infección viroidal (Wang et al., 2004). También se ha demostrado que ciertos dominios del viroide son susceptibles al corte por DCLs (Landry y Perreault, 2005). Por otra parte, la resistencia de las formas maduras del viroide a la degradación por RISC ha sido experimentalmente demostrada en plantas de tomate y N. benthamiana infectadas con PSTVd (Itaya et al., 2007) y HSVd (Gomez y Pallas, 2007), respectivamente. Además, al menos en el caso de HSVd, se ha demostrado que las formas maduras del viroide, no solo escapaban al silenciamiento 
sino que eran capaces de transportarse sistémicamente a través de injerto e inducir infección sistémica en el tejido injertado (Gomez and Pallas, 2007).

Sin embargo, en estudios posteriores se observó que altas concentraciones de pequeños ( 22nt) RNAs artificiales de doble cadena derivados de secuencias de PSTVd, CEVd y CChMVd en el inóculo viroidal inducían un ligero retraso en el proceso de infección (Carbonell et al., 2008). Además plantas transgénicas para una secuencia tipo horquilla derivada de PSTVd mostraban resistencia parcial a la infección por este viroide (Schwind et al., 2009). A este respecto es importante destacar que en ninguno de estos trabajos se demostró que esta interferencia en el proceso de infección estuviera relacionada con la susceptibilidad de las formas maduras de los viroides al silenciamiento de RNA.

Ante esta serie de resultados contradictorios consideramos necesario aportar nuevas evidencias que permitieran arrojar luz sobre la relación existente entre la maquinaria de silenciamiento de RNA y la patogénesis viroidal de una manera directa, esto es, estudiando la interacción entre componentes fundamentales de la maquinaria de silenciamiento de RNA y los viroides.

Para realizar este análisis enfocamos nuestro interés en dos variables que afectan al silenciamiento de RNA, una bioquímica, la RNA polimerasa RNA dependiente 6 (RDR6), y otra ambiental, la temperatura. La RDR6 es un componente esencial del silenciamiento de RNA inducido por transgenes y virus, además de uno de los componentes básicos del fenómeno de la transitividad (Dalmay et al., 2000; Mourrain et al., 2000; Vance y Vaucheret, 2001; Vaistij et al., 2002). Además, RDR6 está implicada en el proceso de biogénesis de los ta-siRNAs y siRNAs derivados de transcritos antisentido (Peragine et al., 2004; Chapman y Carrington, 2007). Por otra parte, la temperatura es un factor ambiental que actúa como regulador del silenciamiento de RNA. Se ha descrito que temperaturas altas activan la maquinaria de silenciamiento mientras que temperaturas bajas inhiben este mecanismo (Szittya et al., 2003; Qu et al., 2005).

Nuestra hipótesis de trabajo era pues que, si la infección viroidal es dependiente del silenciamiento de RNA, la inhibición de la actividad del silenciamiento de RNA debería reducir la intensidad de los síntomas. Además, plantas con deficiencias en las rutas de silenciamiento deberían ser asintomáticas o al menos mostrar una reducción en la gravedad de sus síntomas. Para ello empleamos nuestro modelo transgénico $\mathrm{HSVd} / N$. 
benthamiana y plantas de $N$. benthamiana defectivas para la expresión de RDR6 (rdr6inb) (Schwach et al., 2005).

Primero observamos que los síntomas expresados por las plantas HSVd-Nb a una temperatura óptima para el silenciamiento $\left(28^{\circ} \mathrm{C}\right)$ eran similares a los descritos en la caracterización de este modelo. Sin embargo, la expresión de síntomas decrecía de manera significativa cuando estas plantas se mantenían a temperaturas anteriormente descritas como sub-óptimas para el silenciamiento de RNA $\left(20\right.$ y $\left.14^{\circ} \mathrm{C}\right)$. Por otra parte, y pese a las modificaciones de temperatura, la acumulación de formas circulares y lineales del viroide se mantenía constante, indicando una clara falta de relación entre la acumulación de formas maduras del viroide y la expresión de síntomas (Gómez et al., 2008, capítulo II).

En otra aproximación experimental y usando estas plantas crecidas a 28 y $14^{\circ} \mathrm{C}$ como fondo para expresar de manera transitoria una construcción que llevaba el gen reportero de la proteína de fluorescencia verde (GFP) fusionado al RNA del HSVd, se comprobó la existencia de una relación directa entre el nivel de silenciamiento de RNA y la expresión de síntomas .

No obstante, no podíamos descartar la posibilidad de que a bajas temperaturas $\left(14^{\circ} \mathrm{C}\right)$ se inhibiese la interacción del viroide con algún factor del huésped implicado en la sintomatología viroidal. Estas dudas quedaron totalmente despejadas cuando a la misma temperatura $\left(28^{\circ} \mathrm{C}\right)$ se analizó la infección sistémica por injerto de plantas de $N$. benthamiana control y plantas $r d r 6 i-N b$. En estos ensayos se demostró que los injertos rdr6i-Nb no desarrollaban síntomas pese a que acumulaban altas concentraciones de formas maduras de HSVd. Además, estos injertos $r d r 6 i-N b$ acumulaban una menor cantidad de vd-sRNAs derivados de HSVd. Esos resultados indicaban de manera robusta que en la interacción HSVd-N.benthamiana la expresión de síntomas era un proceso estrictamente ligado al silenciamiento de RNA mediado por RDR6 y totalmente independiente de los niveles de acumulación del patógeno en la planta, aportando la primera evidencia experimental directa sobre la existencia de una estrecha relación entre la patogénesis viroidal y el silenciamiento de RNA específico de viroides, que había sido previamente sugerida por diversos autores (Papaefthimiou et al., 2001; Markarian et al., 2004; Wang et al., 2004) (figura 15). 


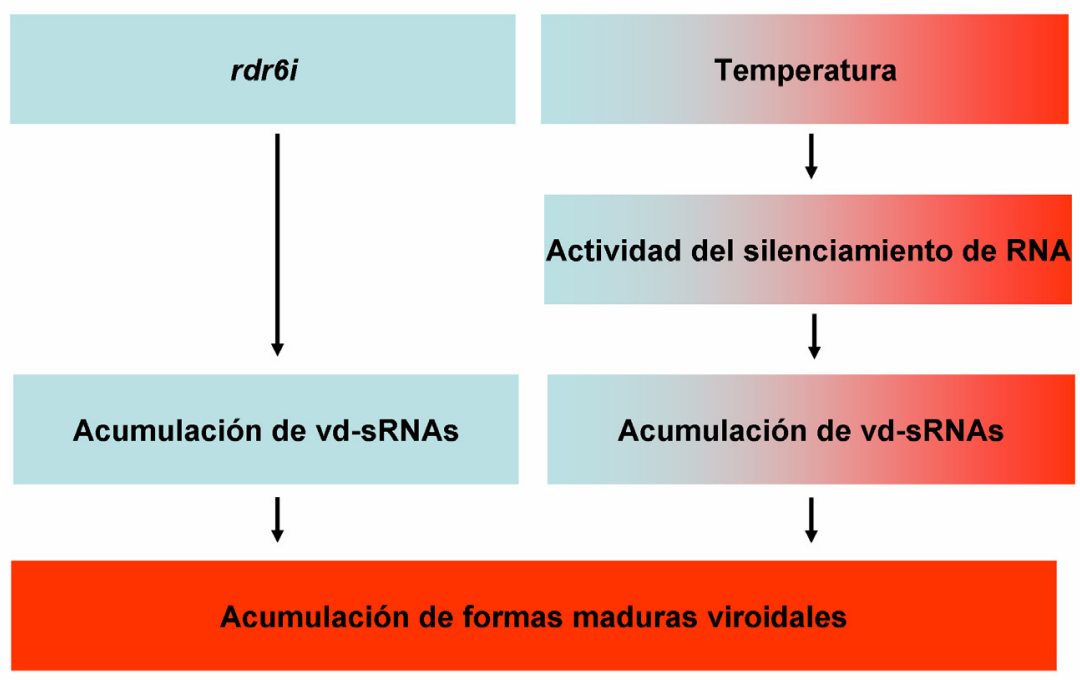

Sintomatología

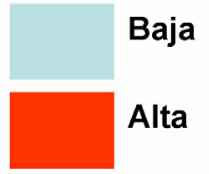

Figura 15. La sintomatología viroidal es dependiente de la actividad del silenciamiento de RNA y de la acumulación de los vd-sRNAs, y no de la acumulación de formas maduras de HSVd en Nicotiana benthamiana. El estudio de la influencia de dos factores (la acción de RDR6 y de la actividad del silenciamiento de RNA, dependiente de la temperatura) indica que en una infección de HSVd sobre Nicotiana benthamiana la sintomatología depende de la acumulación de vd-sRNAs y no de la acumulación de formas maduras, que es alta tanto en las plantas mutantes rdr6i como a bajas temperaturas, situaciones en las que no se da una respuesta sintomatológica, o ésta es más atenuada.

\section{Un modelo de patogénesis para los viroides de la familia Pospiviroidae}

Una de las cuestiones que surgen inmediatamente de las conclusiones de nuestro trabajo anterior es en cual de las vías de silenciamiento de RNA dependientes de RDR6 estaría implicada en el proceso de patogénesis inducido por los viroides nucleares. Varias observaciones previas nos llevaron a especular que el proceso patogénico inducido por la infección viroidal podría estar asociado con el proceso de biogénesis de trans acting siRNAs (tasiRNAs) (Tabla 2).

Los tasiRNAs son una clase de sRNAs endógenos que intervienen en la regulación de diversos procesos de desarrollo de la planta (Peragine et al., 2004; Adenot et al., 2006; Vaucheret, 2006). Al igual que los miRNAs, sus precursores provienen de loci definidos y son sintetizados por la misma maquinaria que estos (Vaucheret, 2006). 
Estos genes TAS se transcriben en RNAs primarios largos que no codifican proteínas y únicamente actúan como precursores para la producción de tasiRNAs (Peragine et al., 2004; Vazquez et al., 2004; Allen et al., 2005).

\begin{tabular}{|c|c|}
\hline Biogénesis de los ta-siRNAs & Ciclo de vida de los Pospiviroidae \\
\hline Precursores de los ta-siRNAs & Intermediarios replicativos de polaridad+ \\
\hline $\begin{array}{l}\text { Transcritos a partir de genes TAS específicos por } \\
\text { la RNA Polimerasa II }\end{array}$ & $\begin{array}{l}\text { Transcritos a partir de un RNA complementario } \\
\text { (negativo) por la RNA Polimerasa II }\end{array}$ \\
\hline RNAs de simple cadena, nucleares y no codificantes. & RNAs de simple cadena, nucleares y no codificantes. \\
\hline $\begin{array}{l}\text { Contienen sitios de unión específicos para el corte } \\
\text { guiado por miRNAs que da lugar a RNAs con } \\
\text { extremos definidos, que son cruciales para la precisión } \\
\text { de la generación en fase de dsRNAs y ta-siRNAs } \\
\text { maduros. }\end{array}$ & $\begin{array}{l}\text { Los intermediarios replicativos son cortados en RNAs } \\
\text { monoméricos lineales en posiciones específicas, dando } \\
\text { lugar a RNAs con extremos bien definidos que son } \\
\text { potenciales generadores de dsRNAs en fase y ta- } \\
\text { siRNAs derivados del viroide (vd)ta-siRNAs. }\end{array}$ \\
\hline $\begin{array}{l}\text { La biogénesis de ta-siRNAs se inicia por la formación } \\
\text { de un dsRNA por RDR6. }\end{array}$ & $\begin{array}{l}\text { La sintomatología del HSVd en N.benthamiana es } \\
\text { dependiente del silenciamiento de RNA mediado por } \\
\text { RDR6. }\end{array}$ \\
\hline $\begin{array}{l}\text { El reclutamiento de RDR6 por el transcrito precursor } \\
\text { de los ta-siRNAs puede deberse a la falta de extremos } \\
\text { 5' cap y/o 3'poliadenilado. }\end{array}$ & $\begin{array}{l}\text { El monomero lineal positivo del viroide carece de } \\
\text { extremo 5'cap y cola poliadenilada en 3'. }\end{array}$ \\
\hline ta-siRNAs maduros & (vd)siRNAs \\
\hline Son activos en el citoplasma. & $\begin{array}{l}\text { La acumulación de vd-siRNAs de PSTVd tiene lugar } \\
\text { principalmente en el citoplasma. }\end{array}$ \\
\hline $\begin{array}{l}\text { Median el corte de transcritos celulares endógenos } \\
\text { parcialmente homólogos. }\end{array}$ & $\begin{array}{l}\text { En el modelo patogénico viroidal mediado por } \\
\text { silenciamiento de RNA, los vd-siRNAs median el corte } \\
\text { de transcritos homólogos del huésped. }\end{array}$ \\
\hline $\begin{array}{l}\text { Los ta-siRNAs funcionan como reguladores de } \\
\text { transcritos relacionados con el crecimiento, la floración } \\
\text { y el desarrollo de la planta. }\end{array}$ & $\begin{array}{l}\text { Las infecciones viroidales se describen como } \\
\text { enfermedades del desarrollo. Los síntomas más } \\
\text { comunes son enanismo, alteraciones en la floración y } \\
\text { deficiencias en el desarrollo de la planta. }\end{array}$ \\
\hline
\end{tabular}

Tabla 2. Similaridades entre la biogénesis de los ta-siRNA y el ciclo de vida de los miembros de la familia Pospiviroidae.

Esta producción de tasiRNAs viene mediada por el corte de dichos transcritos primarios por miRNAs. Una vez cortados, son reconocidos por el complejo RDR6/SGS3 para servir de molde para la síntesis de dsRNA que es cortado por DCL4 para producir siRNAs de $21 \mathrm{nts}$ en fase, denominados tasiRNAs (Peragine et al., 2004; Vazquez et al., 2004; Gasciolli et al., 2005; Yoshikawa et al., 2005). Las dianas de estos tasiRNAs son genes (distintos al precursor) que codifican, entre otros, factores de trascripción implicados en la respuesta a auxinas (ARF3-4), proteínas de la familia de repeticiones de pentatricopeptidos (PPR), factores de transcripción MYB y proteínas 
cuya función es aún hoy desconocida (Adenot et al., 2006; Fahlgren et al., 2006; Garcia et al., 2006; Rajagopalan et al., 2006). La biogénesis de los tasiRNAs y el proceso de replicación de los miembros de la familia Pospiviroidae comparten ciertas similitudes bioquímicas (tabla 2). Ambos son RNAs de cadena única no codificantes, sintetizados por la RNA polimerasa II y se acumulan específicamente en el núcleo. Estas evidencias estructurales junto con la implicación de RDR6, tanto en la biogénesis de tasiRNAs como en la producción de síntomas, nos llevaron a proponer un modelo para explicar la interacción entre el silenciamiento de RNA y el proceso de patogénesis asociado a las infecciones por viroides nucleares (Figura 16).

En este modelo (Gómez et al., 2009) proponemos que durante la infección por miembros de la familia Pospiviroidae, los monómeros lineales de polaridad positiva serían reconocidos (al igual que ocurre con los pre-tasiRNAs) por RDR6 (posiblemente debido a la carencia de extremo 5' cap o 3' poli-A) y usados como moldes para generar un dsRNA derivado del viroide, que servirían como sustrato para DCL4 en la generación de vd-sRNAs. Los vd-sRNAs producidos de este modo serían transportados al citoplasma donde una vez incorporados en RISC actuarían de manera similar a los tasiRNAs regulando en trans mRNAs endógenos de la planta, homólogos a las secuencias viroidales. Las formas maduras del viroide, resistentes a RISC (Gomez y Pallas, 2007; Itaya et al., 2007) serían capaces de evadir la degradación mediada por estos complejos. Además, nuestro modelo ofrece una explicación a la compartimentalización diferencial en el nucleolo de los multímeros positivos (susceptibles a la actividad RISC) durante el proceso de replicación (Qi y Ding, 2003). Según nuestra visión, para evitar su degradación en el nucleoplasma, estas formas lineales multiméricas se acumularían en el nucleolo (donde encontrarían refugio del silenciamiento de RNA) para ser procesadas y ligadas. Estas formas circulares (resistentes al silenciamiento) podrían entonces salir del nucleolo y circular por el resto del núcleo y el citoplasma. Es importante destacar que este modelo trata de aportar un marco conceptual para explicar las bases moleculares de la sintomatología asociada a infecciones por viroides nucleares y la dependencia de la patogénesis de la actividad de RDR6. Aunque la implicación de la maquinaria de silenciamiento de RNA en la patogénesis viroidal es una idea plausible y elegante, somos conscientes de que son necesarias todavía más evidencias que soporten de manera robusta esta conclusión. 


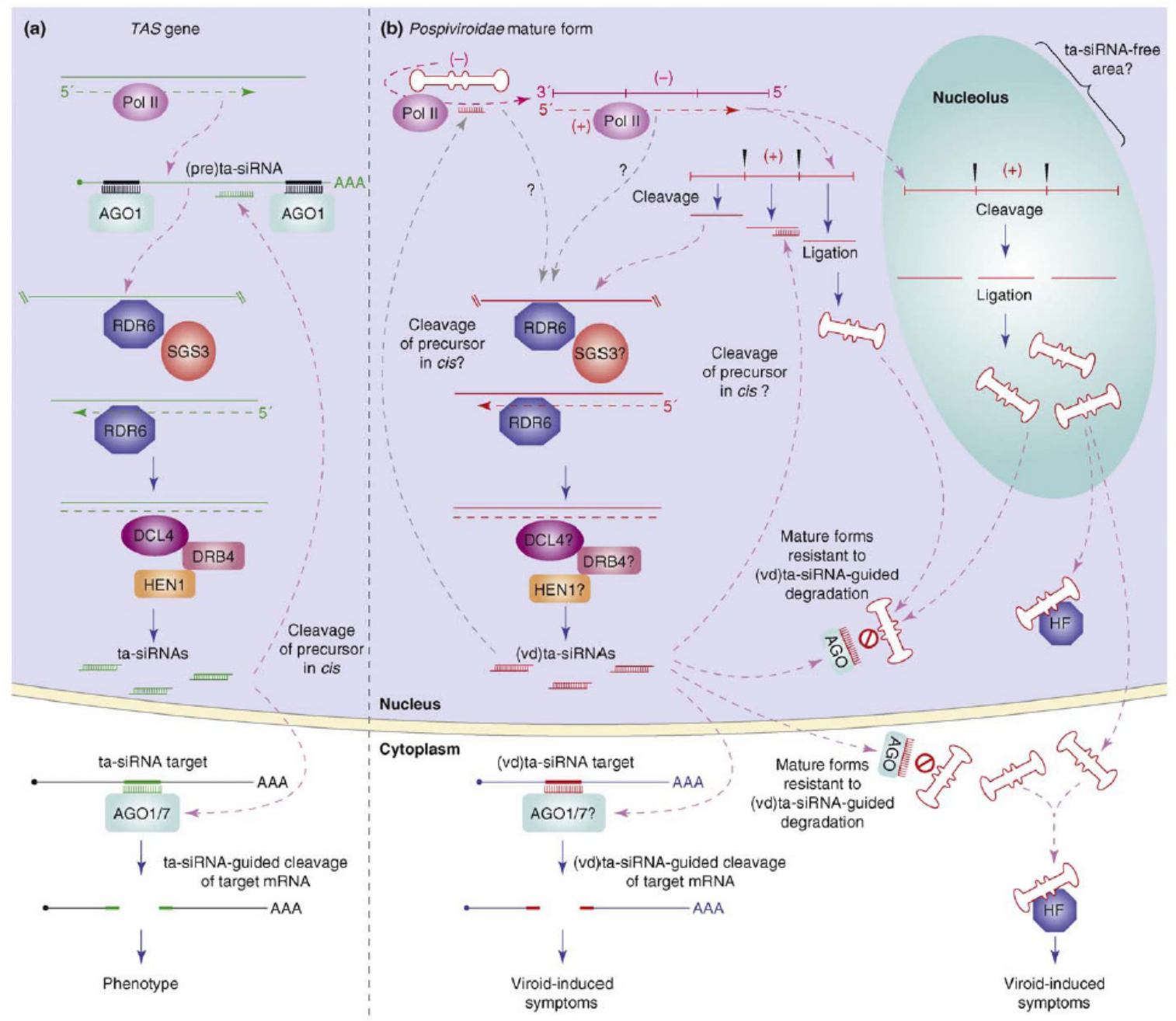

Figura 16: Modelo propuesto para el papel de la ruta de biogénesis de los ta-siRNAs en el proceso patogénico inducido por viroides nucleares. La replicación de los miembros de la familia Pospiviroidae genera RNAs monoméricos de polaridad positiva que son cortados por factores del huésped desconocidos, con extremos 3' y 5' bien definidos. El procesamiento de los oligómeros de RNA de polaridad positiva en monómeros circulares ocurre principalmente en el nucleolo. No obstante, en una ruta alternativa los RNAs multiméricos de polaridad positiva se cortarían y circularizarían en el nucleoplasma. Los monómeros de simple cadena acumulados en el nucleoplasma (que carecen de extremos 5'cap o cola 3' poliadenilada) podrían actuar como moldes para RDR6, induciendo la producción de sRNAs derivados del viroide. Los vd-sRNAs producidos en fase podrían entonces incorporarse a la ruta de biogénesis de los ta-siRNAs para generar ta-siRNAs derivados del viroide (vd)ta-siRNAs. Los (vd)ta-siRNAs maduros podrían ser transportados al citoplasma donde podrían guiar el corte de mRNAs del huésped parcialmente homólogos que inducirían una respuesta sintomática. Además, los (vd)ta-siRNAs podrían actuar potencialmente sobre sus precursores, forzando el tráfico de los intermediarios replicativos (susceptibles a la degradación mediada por el silenciamiento de RNA) al nucleolo para completar su ciclo replicativo. Los viroides maduros, resistentes al silenciamiento de RNA podrían evadir esta ruta regulatoria. La ruta de biogénesis de ta-siRNAs se muestra en el panel izquierdo. Alternativamente, la respuesta sintomática podría darse debido a la interacción entre el RNA genómico del viroide y factores del huésped desconocidos. Pol II: RNA polymerasa II, RDR6: RNA polimerasa RNA dependiente 6, SGS3: Suppressor of Gene Silencing 3, DCL4: Dicer-like Protein 4, DRB4: dsRNA-binding Protein 4; HEN1: Hua Enhancer 1 (miRNA metiltransferasa), HF: Factor del huésped desconocido. 
Sería necesario analizar la implicación de componentes aguas abajo de RDR6 en la sintomatología viroidal o encontrar en el transcriptoma del huésped los posibles mRNAs diana de los vd-sRNAs. No se puede descartar, no obstante, que en algunas interacciones los viroides induzcan síntomas por mecanismos alternativos y tal vez independientes de la actividad de RDR6 (Di Serio et al., 2010).

Por otra parte, nuestro modelo también contempla el hecho de que los viroides produzcan sRNAs derivados de su genoma a través de varias rutas de biogénesis, como lo demuestra el que detectemos sRNAs derivados del HSVd en plantas rdr6i. El clonado mediante secuenciación masiva de estos vd-sRNAs se antoja pues como una herramienta necesaria para poder conocer de primera mano la naturaleza de los sRNAs específicos del viroide. Esta aproximación constituye la imagen más precisa de la acción de los componentes de la maquinaria de silenciamiento sobre los viroides en un escenario donde no es posible emplear plantas mutantes para las distintas DCLs.

\section{Caracterización de los SRNAs derivados de HSVd durante el proceso de infección}

Los mecanismos que regulaban la biogénesis de los pequeños RNAs derivados de los viroides constituían al momento de inicio de esta tesis una cuestión que permanecía sin repuesta. Este desconocimiento estaba originado principalmente en el hecho de que Arabidopsis (organismo para el cual se dispone de la totalidad de mutantes de las diferentes DCLs) no fuese un huésped para infecciones viroidales.

En estudio previos realizados mediante técnicas de clonaje a baja escala se había determinado que los sRNAs derivados del genoma viroidal presentan el tamaño típico de los sRNAs producto de DCL, entre 20 y 24 nts (Itaya et al., 2007; Machida et al., 2007; Martin et al., 2007; St-Pierre et al., 2009), y que además de poseer un grupo fosfato en su extremo 5' (evidencia de la acción de DCL), están metilados en su extremo 3' (Martin et al., 2007). Esta serie de evidencias indirectas sustentaban la idea de que el RNA genómico del viroide podría ser un potencial sustrato para el procesamiento mediado por DCLs.

Las formas biológicas del los viroides son moléculas circulares con una compleja estructura secundaria generando, por tanto, dsRNAs potenciales sustratos de DCL. No obstante, podrían también serlo sus intermediarios replicativos o dsRNAs generados a partir de las formas lineales por la acción de RDRs celulares. Estas presunciones fueron subsecuentemente reforzadas por una serie de trabajos que demostraron que una región estructurada de PLMVd y el RNA genómico del PSTVd 
podían, al ser incubados con extractos de germen de trigo y Arabidopsis respectivamente, actuar como sustratos para la acción de una o más DCLs (Landry y Perreault, 2005; Itaya et al., 2007).

Por otra parte, los primeros ensayos de secuenciación a baja escala de sRNAs derivados de distintos viroides aportaron datos en algunos casos contradictorios acerca de los potenciales precursores de los vd-sRNAs y sobre las enzimas de la maquinaria de silenciamiento de RNA implicadas en su procesamiento (Itaya et al., 2007; Machida et al., 2007; Martin et al., 2007; St-Pierre et al., 2009). Tomados en conjunto, estos trabajos dibujaron un difuso retrato sobre la biogénesis de vd-sRNAs sugiriendo la existencia de diversos escenarios posibles. Para la familia Pospiviroidae, las moléculas maduras del viroide podrían actuar como sustrato de DCL4/DCL2 generando vd-sRNAs primarios en su tránsito por el citoplasma. Pero también los intermediarios replicativos o la molécula madura, mediante la acción de DCL1, podrían ser precursores de estos vd-sRNAs en el núcleo. Por otra parte, sería posible que los vd-sRNAs primarios iniciaran a partir de intermediarios replicativos (en un proceso mediado por RDRs celulares) la síntesis de dsRNAs que serían potenciales sustratos para las DCLs citoplásmicas. Los vd-sRNAs derivados de los miembros de la familia Avsunviroidae deberían ser originados por la acción de DCLs citoplásmicas, ya que no se han descrito DCLs con localización cloroplástica.

Sin lugar a dudas, uno de los puntos en el que todos los trabajos de clonado y secuenciación de baja escala llegaban a coincidir era en lo limitadas que podían ser este tipo de aproximaciones para inferir el proceso de biogénesis de los vd-sRNA y en la necesidad de futuros estudios basados en el uso de técnicas más sensibles y masivas de secuenciación. La secuenciación del "sRNAoma" ha sido el objetivo de muchos laboratorios, incluso desde las primeras fases del descubrimiento de los sRNAs, con el propósito de entender su biogénesis y función (Lee et al., 1993). El desarrollo de las nuevas técnicas de secuenciación masiva ha ayudado enormemente a aumentar la cantidad de secuencias de sRNAs a analizar (Hafner et al., 2008). La secuenciación masiva emergía pues como una herramienta indispensable en nuestro esfuerzo de caracterizar la población de pequeños RNAs derivados de un viroide nuclear.

Ante estas circunstancias decidimos emplear la interacción de HSVd con su huésped natural Cucumis sativus para intentar generar mediante estudios de secuenciación masiva, un retrato más exacto acerca de qué componentes de la 
maquinaria de silenciamiento y formas precursoras del viroide podrían estar implicados en la producción de vd-sRNAs. Para ello empleamos dos tejidos diferentes de pepino, hoja y exudado floemático, este último con la intención de obtener las primeras pistas sobre la naturaleza de la señal sistémica del silenciamiento de RNA.

El primer análisis de las secuencias recuperadas en la librería de sRNAs obtenida a partir de hoja indicó que la mayoría de los sRNAs derivados del viroide correspondían a lecturas de 21, 22 y 24 nts, coincidiendo con una posible producción jerarquizada coordinada de DCL4, DCL2 y DCL3 (Bouche et al., 2006; Deleris et al., 2006). Por otra parte, la distribución de secuencias de polaridad positiva y negativa a un ratio similar a lo largo del genoma viroidal, indicaba que estos vd-sRNAs estaban originados por la acción de DCL sobre un dsRNA perfectamente complementario generado a partir de un precursor lineal. El hecho de que recuperásemos de nuestra librería múltiples pares de vd-sRNAs con dos extremos “colgantes” en 3', servía como evidencia adicional de la acción de DCL sobre dsRNAs de origen viroidal (Martínez et al., 2010; capítulo III).

Es importante destacar que nuestros resultados relativos a la distribución (a lo largo de todo el genoma) y polaridad (similar número de secuencias positivas y negativas) se encuentran en aparente contradicción con todos los ensayos de secuenciación a baja escala mencionados anteriormente. Nuestros resultados (reforzados por observaciones similares realizadas durante el transcurso de esta tesis con otros viroides en estudios de secuenciación masiva [Di Serio et al., 2009; Navarro et al., 2009; Bolduc et al., 2010; Diermann et al., 2010]) indican que todo el genoma viroidal es diana de la maquinaria de silenciamiento, soportando un modelo en el cual el grueso de los vd-sRNAs se originaría a partir de precursores de doble cadena generados por RDRs celulares procesados por diferentes DCLs, tanto nucleares como citoplasmáticas (figura 17). Sin embargo, no podemos excluir la posibilidad de que ciertos sRNAs específicos de HSVd deriven de regiones concretas del viroide con una alta estructura secundaria que pudieran, por ejemplo, servir como sustratos para la actividad de DCL1. Posiblemente, el proceso por el cual se generan los vd-sRNAs es más complejo de lo esperado e involucre distintas rutas de biogénesis y compartimentos celulares.

Los vd-sRNAs de nuestra librería contienen preferentemente un residuo citosina en posición 5' lo cual sugiere una alta afinidad de unión a AGO5, al menos en Arabidopsis (Mi et al., 2008; Takeda et al., 2008). El papel de AGO5 en el silenciamiento de RNA no está claro y su actividad en defensa antiviral o contra 
patógenos no se ha establecido nunca (Brodersen y Voinnet, 2006; Chapman y Carrington, 2007; Ruiz-Ferrer y Voinnet, 2009).

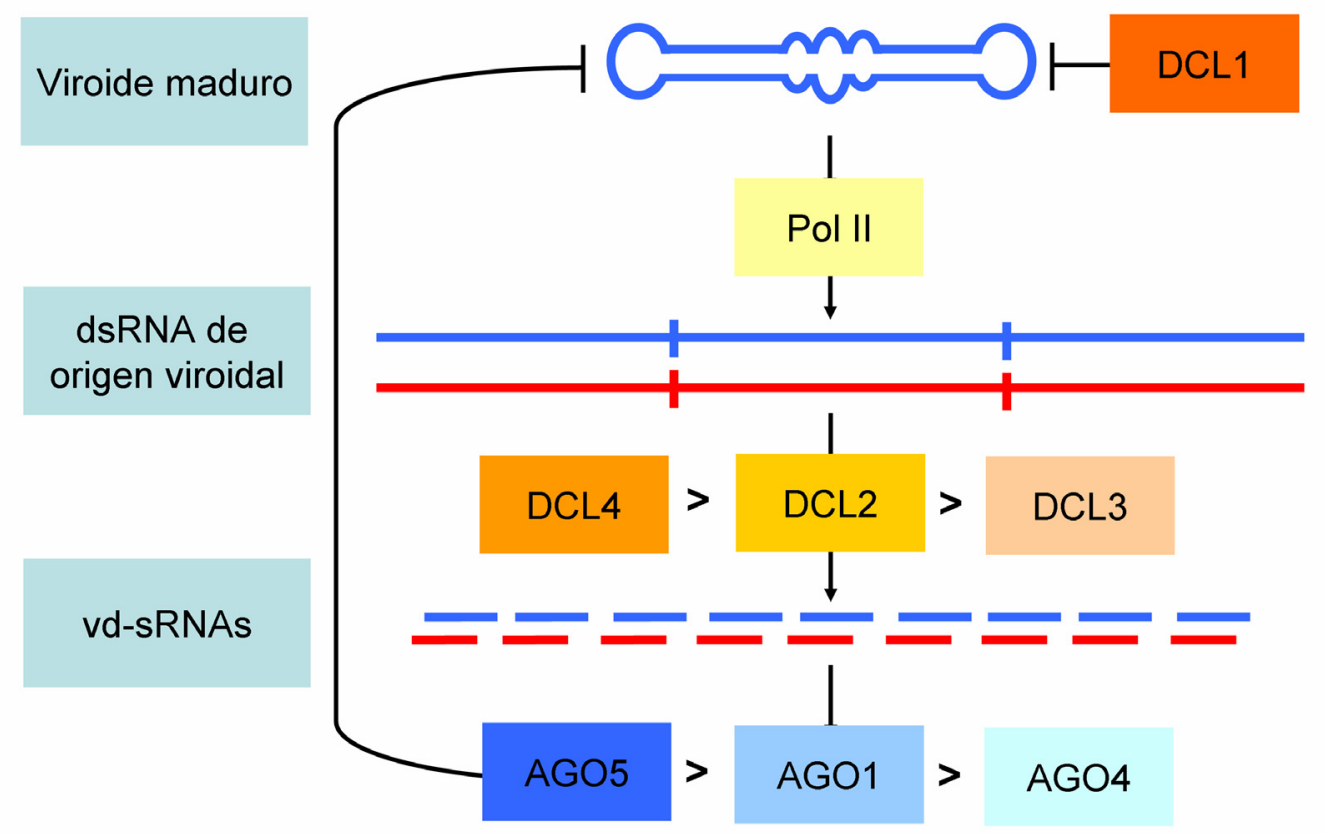

Figura 17. Resumen de los resultados obtenidos sobre la posible biogénesis de vd-sRNAs derivados del HSVd en hojas de pepino. Los vd-sRNAs de HSVd provienen en su mayoría de un dsRNA de origen viroidal y al parecer no de la molécula madura. Las encimas Dicer-like implicadas en su biogénesis serían por orden decreciente DCL4, 2 y 3. Además serían cargados preferencialmente en AGO5 (no involucrada en silenciamiento de RNA antiviral), lo que podía explicar la resistencia al silenciamiento de las formas maduras del HSVd.

Como apuntan Ruiz-Ferrer y Voinnet (2009), es posible que la unión de sRNAs a AGOs sin una actividad antiviral demostrada pueda prevenir la degradación mediada por RISC de los ácidos nucleicos de los que derivan. Esta situación podría estar ocurriendo en nuestro sistema, y por ello las formas maduras viroidales no serían cortadas por los vd-sRNAs cargados en RISC, lo que aportaría una explicación alternativa a la resistencia de éstas al silenciamiento de RNA (Gomez y Pallas, 2007; Itaya et al., 2007).

En este trabajo, además de la secuenciación masiva de sRNAs derivados de hojas llevamos a cabo la preparación de otra librería a partir del exudado floemático de plantas de pepino infectadas con HSVd, con el objetivo de alcanzar una visión global de la infección viroidal y estudiar la translocación de los vd-sRNAs a través del floema y su imposible implicación en el proceso de patogénesis. 
Para nuestra sorpresa en el floema se acumulaban preferentemente vd-sRNAs de $22 \mathrm{nts}$, invirtiendo totalmente el ratio obtenido en hojas donde predominan los de $21 \mathrm{nts}$. En base a esta observación, y considerando que hasta el momento no se ha descrito actividad DCL en el floema, es coherente especular que este cambio en los patrones de distribución vd-sRNAs entre estos tejidos estaría originado por la existencia de un transporte diferencial y selectivo de sRNAs de 22 nts desde tejidos no vasculares hacia el floema. Un aspecto interesante de esta observación es el reciente descubrimiento del papel de los sRNAs de $22 \mathrm{nts}$ como precursores de la amplificación del silenciamiento mediada por RDR6 en el fenómeno de la transitividad (Cuperus et al., 2010; Chen et al., 2010). Ante esto, es posible teorizar que el transporte diferencial de sRNAs de $22 \mathrm{nts}$ al floema pueda actuar como un mecanismo endógeno de protección de la planta, en el que la translocación especifica de sRNAs de 22 nts viroidales y endógenos a zonas dístales de la misma serviría para iniciar en estas zonas la producción de sRNAs secundarios que prevengan la invasión sistémica de ácidos nucleicos extraños (tanto endógenos como exógenos) o para controlar a larga distancia diversos aspectos del desarrollo. La observación de que también en planta no infectada exista una acumulación diferencial de sRNAs de 22 nts en el floema provee robustez conceptual a esta idea.

Otra particularidad de los vd-sRNAs floemáticos fue que, en su gran mayoría, provenían de dos zonas bien definidas del genoma de HSVd que no mostraban una acumulación preponderante en hoja. En estas regiones, encontramos una secuencia común altamente representada: AGAnGCG, que estaba consecuentemente presente en la gran mayoría de los vd-sRNAs recuperados del floema. Estos resultados sugieren que tal vez esta secuencia podría ser una "etiqueta" que mediara la interacción con algún factor de la planta para favorecer el transporte diferencial de sRNAs al sistema vascular. Al igual que lo ocurrido con el tamaño, los sRNAs endógenos de pepino que poseen esta "etiqueta" se encuentran sobrerrepresentados en el exudado floemático. Por tanto, el análisis de los vd-sRNAs recuperados del floema dibujan un escenario donde tal vez el transporte de sRNAs al sistema vascular sea un proceso regulado a dos niveles diferentes: tamaño y secuencia.

Cabe destacar, que paralelamente al desarrollo y publicación de este trabajo se han publicado una serie de trabajos de secuenciación masiva de vd-sRNAs para distintos viroides tanto nucleares como cloroplásticos: PLMVd (Di Serio et al., 2009; Bolduc et al., 2010), HSVd (Navarro et al., 2009), GYSVd1 (Navarro et al., 2009) y PSTVd (Di Serio et al., 2010). En todas las secuenciaciones se aprecia una distribución 
de vd-sRNAs similar, cubriendo todo el genoma del viroide, con una acumulación diferencial en puntos específicos del genoma y con una acumulación similar de secuencias positivas y negativas. En ninguna secuenciación se ha logrado relacionar la acumulación en estos puntos específicos con una mayor estructura secundaria en esas zonas del genoma viroidal. La distribución de tamaños de los vd-sRNAs en todas las secuenciaciones parece mostrar una preferencia de acumulación de los vd-sRNAs de 21-22 nts, seguidos de los de 24 (HSVD, GYSVd y PSTVd) o 20 nts (PLMVd), siendo los menos acumulados 23 y 24 nts (PLMVd) o 23 y 20 nts (HSVd, GYSVd y PSTVd). Esto indica que varias DCLs están implicadas en la síntesis de estos sRNAs viroidales. Al provenir principalmente de un dsRNA las DCLs mayoritariamente implicadas serían DCL4, DCL2 y DCL3.

Todos estos datos corroboran nuestras observaciones y proveen evidencias experimentales que refuerzan nuestro modelo de patogénesis. Sin embargo, no resultan categóricos para determinar de qué manera los vd-sRNAs están implicados en la inducción de síntomas ni descartar la posibilidad de que las alteraciones fisiológicas inducidas en el huésped durante la infección pudieran estar relacionadas con la desregulación de diversos sRNAs endógenos de la planta con importantes funciones reguladoras de desarrollo como los miRNAs. Para analizar esta posibilidad debíamos primero conocer y caracterizar la población de sRNAs (principalmente miRNAs) endógenos del huésped C. sativus, desconocida hasta el momento.

\section{Alteraciones inducidas por la infección viroidal en el metabolismo de sRNAs endógenos del huésped}

La interacción planta-patógeno puede inducir una respuesta de la maquinaria de silenciamiento endógena de la planta de dos maneras distintas. Por una parte, actúa sobre el genoma del patógeno generando sRNAs derivados de su genoma y, por otra, modifica la expresión de reguladores o efectores de las rutas de defensa del hospedador (Ruiz-Ferrer y Voinnet, 2009). La alteración en los niveles de acumulación de determinados miRNAs ha sido descrita en procesos de infección inducidos por patógenos no virales tales como Pseudomonas syringae (Navarro et al., 2006; Fahlgren et al., 2007; Jagadeeswaran et al., 2009) y Agrobacterium (Pruss et al., 2008). Por otra parte, se han asociado también diversas infecciones virales con alteraciones en los niveles de miRNAs en la planta. Tal es el caso de plantas de Nicotiana benthamiana en las que el proceso de infección por diferentes virus (TMV, virus del mosaico del tomate 
[ToMV], virus del grabado del tabaco [TEV], virus Y de la patata [PVY] y virus X de la patata $[\mathrm{PVX}]$ ) correlaciona con la acumulación de los varios miRNAs (miR156, 160, 164,166, 169 y 171), sugiriendo que los virus podrían explotar la vía de los miRNAs durante su proceso de patogénesis (Bazzini et al., 2007).

Además, dos miRNAs específicos de Brassica rapa (bra-miR158 y bramiR1885) se sobreacumulan en infecciones del virus del mosaico del nabo (TuMV). La sobre-expresión de estos miRNAs es además muy específica ya que ni la infección por los virus del mosaico del pepino (CMV) y del mosaico del tabaco (TMV) o el hongo Sclerotinia sclerotiorum afectaron a los niveles de acumulación de estos dos miRNAs (He et al., 2008). Recientemente, se ha asociado un incremento en el nivel de actividad transcripcional del promotor del miRNA 164a con la infección del virus del mosaico de la colza (ORMV) (Bazzini et al., 2009). Además, la infección con CMV induce en plantas de tomate la sobreacumulación de una serie de miRNAs (miR162, 164, 165 y 168) que es específica de cepa viral (Cillo et al., 2009). Los supresores del silenciamiento de RNA de virus de plantas también alteran por sí mismos los niveles de miRNAs endógenos, lo cual provoca cambios en la acumulación de mRNAs (Kasschau et al., 2003; Dunoyer et al., 2004; Zhang et al., 2006).

Pese a todos los trabajos existentes acerca de cómo diversos patógenos afectan el balance de miRNAs en la planta no existen estudios dedicados a analizar en profundidad cómo el proceso de infección viroidal altera los niveles este tipo de RNAs reguladores en el huésped. Los únicos datos existentes derivan de un análisis preeliminar realizado mediante hibridación sobre algunos miRNAs en plantas de tomate infectadas con CEVd (Martin et al., 2007) y un reciente trabajo de secuenciación masiva que analiza la variación en los niveles de acumulación de diversos miRNAs en plantas de tomate infectadas con PSTVd (Diermann et al., 2010).

Ante esta falta de conocimientos previos y considerando que la alteración del balance de miRNAs en la planta podría constituir otra de las posibles relaciones existentes entre el proceso de patogénesis inducido por los viroides nucleares y el silenciamiento de RNA, decidimos investigar cómo HSVd afectaba el metabolismo de los miRNAs en pepino. Teniendo en cuenta que no existían trabajos sobre sRNAs en esta especie, nuestro primer objetivo fue realizar un inventario de los sRNAs endógenos de pepino así como una caracterización de los miRNAs encontrados y sus potenciales precursores. 
El análisis del perfil general de sRNAs únicos recuperados de pepino no infectado muestra que la clase más frecuente es la de $24 \mathrm{nt}$. Este dato, que se repite de manera reiterada en las especies anuales, podría estar ligado con la regulación de distintas etapas del desarrollo mediante la inducción de metilación (Pantaleo et al., 2010). Al considerar las secuencias totales de la librería, la clase predominante es $22 \mathrm{nts,}$ observación relevante no descrita aún en ninguna otra especie vegetal. Los sRNAs de 22 nt constituyen una familia poco estudiada a nivel de sRNAs endógenos, aunque como mencionamos antes, trabajos recientes han revelado su implicación en el proceso de generación de siRNAs secundarios, responsables del efecto de transitividad (Cuperus et al., 2010; Chen et al., 2010). Está observación, sumado a la acumulación diferencial de este tipo de sRNAs en el floema, sugiere que $C$. sativus podría convertirse en una planta modelo con un gran potencial para el estudio de este tipo de mecanismos reguladores relacionados con el silenciamiento de RNA.

El análisis de la población de miRNAs en Cucumis sativus exigía, en primer lugar, realizar una serie de agrupaciones. En plantas, los miRNAs comunes a distintas especies pueden agruparse en dos grupos, conservados y no conservados. Los miRNAs conservados están presentes en todas las especies y en general están asociados a funciones básicas del desarrollo vegetal; los no conservados en cambio son miRNAs relativamente comunes pero que su distribución entre especies es diferente (Voinnet, 2009; Gong et al., 2010; Cuperus et al., 2011). A partir de nuestra librería se recuperaron un total de 14.572 lecturas que tenían correspondencia con las secuencias depositadas en la base de datos de miRNAs miRBase. Estas lecturas correspondían a miRNAs que pertenecían a 25 familias diferentes, 19 conservadas y 6 no conservadas (Martínez et al., 2011, capítulo IV).

La regulación de procesos biológicos por miRNAs no es función exclusiva de los miRNAs comunes, sino que existen miRNAs de reciente origen evolutivo que son específicos de especie y que comunmente se acumulan a niveles muy bajos o tienen una expresión diferencial dependiente de estrés o tejido (Voinnet, 2009). En un intento por profundizar nuestro conocimiento de la población de miRNAs en pepino y valiéndonos de la reciente secuenciación de su genoma (Huang et al., 2009), abordamos la búsqueda y caracterización de miRNAs potencialmente específicos de especie en pepino. Este análisis nos permitió identificar, en plantas no infectadas, 7 nuevos miRNAs (csa-miR1, csa-miR2, csa-miR3, csa-miR4-a, csa-miR4-b, csa-miR5, csa-miR6) candidatos a ser específicos de Cucumis sativus (Martínez et al., 2011). Mediante predicción 
bioinformática fue posible identificar en el genoma de pepino dianas potenciales para 3 de estos ribo-reguladores, csa-miR2, csa-miR4 y csa-miR5. Debido al condicionante de que el genoma de pepino no posee aun anotaciones funcionales, no estamos en condiciones de identificar con certeza la función de los genes diana de estos miRNAs. El hecho de que no hayamos sido capaces de identificar potenciales dianas para todos los nuevos miRNAs descritos puede estar relacionado con estos errores en la anotación de las secuencias (solo es la primera aproximación) o a que la variedad empleada en este estudio (variedad Suyo) no coincide con la secuenciada. Además, el uso de herramientas bioinformáticas para la predicción de mRNAs diana es limitada. Recientemente se han identificado nuevas dianas para el miR398 en Arabidopsis que no habían sido predichas bioinformaticamente, poniendo así de manifiesto la existencia de limitaciones en el uso de estas herramientas (Beauclair et al., 2010).

Una vez determinado el perfil característico de los sRNAs endógenos de pepino, disponíamos de un marco de referencia para poder analizar las alteraciones en este grupo de ribo-reguladores asociadas al proceso infeccioso inducido por el HSVd.

Los resultados obtenidos nos permitieron identificar cinco tipos diferentes de alteraciones inducidas por el HSVd durante la infección (Martínez et al., 2011, capítulo V): a) alteración del perfil general de sRNAs, siendo la familia de 21 nts la de mayor acumulación en planta infectada b) represión de un grupo de miRNAs conocidos c) sobrexpresión de un grupo de miRNAs conocidos d) expresión diferencial en planta infectada de un grupo de miRNAs específicos de pepino y e) alteración en la eficiencia de procesamiento de los miRNAs de planta enferma en general (Figura 18). En principio podríamos asumir una interrelación entre las situaciones a y c, ya que un aumento significativo en los niveles de expresión de los miRNAs durante la infección podría ser responsable de que los sRNAs de $21 \mathrm{nt}$ se convirtieran en la formas mayoritaria en planta enferma. El análisis de nuestra librería indicó que el número de secuencias de miRNAs en plantas infectadas es más de 10 veces superior a lo observado en plantas sanas $(1,96 \%$ del total de sRNAs en plantas sanas y $22,6 \%$ del total de sRNAs en plantas infectadas). Una aproximación mas especifica nos permitió identificar que HSVd induce en plantas infectadas la sobrexpresión, pero sobre todo, la represión drástica de diversos miRNAs. La mayoría de las dianas de los miRNAs reprimidos son genes relacionados con el crecimiento y el desarrollo de la planta como factores de transcripción, receptores de auxinas y precursores de los ta-siRNAs (JonesRhoades y Bartel, 2004; Sunkar y Zhu, 2004; Zhou et al., 2010). 


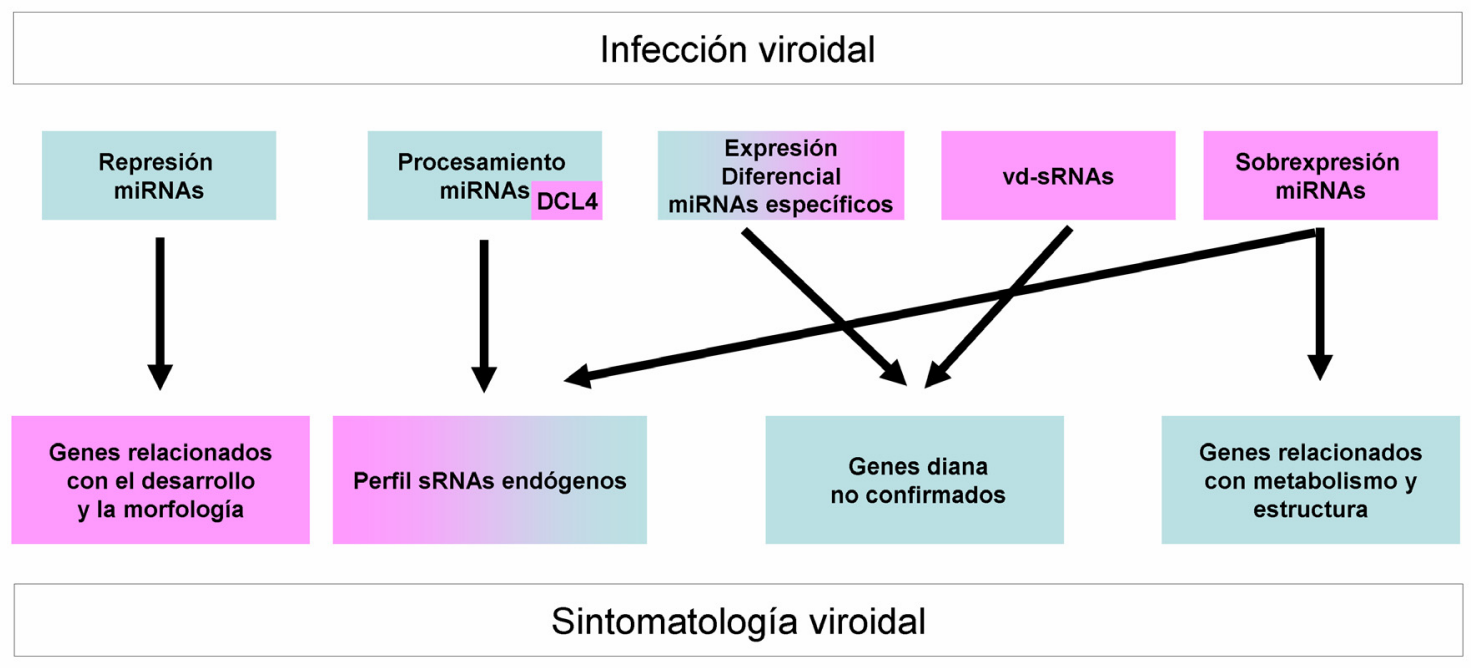

Represión

Sobrexpresión

Figura 18. Diagrama conceptual sobre la posible explicación de la sintomatología viroidal con respecto a la expresión diferencial y biogénesis de los miRNAs de pepino (tanto conocidos como específicos) y de la represión de las potenciales dianas de vd-sRNAs. Las cajas coloreadas en azul indican represión y las coloreadas en rojo sobrexpresión. La sintomatología viroidal podría explicarse como la afección tanto en la biogénesis como en la expresión de tanto los miRNAs conocidos como los específicos de pepino, por la represión/sobrexpresión de sus respectivos genes diana. Además se añade al conjunto la potencial interferencia de los vd-sRNAs con sus genes diana.

Este resultado nos lleva a pensar que la disminución en la acumulación de estos miRNAs durante la infección viroidal induciría la sobrexpresión de sus correspondientes dianas activando genes relacionados con la respuesta a estrés inducido por patógenos, de manera similar a lo observado en plantas de arroz sometidas a estrés abiótico (Zhou et al., 2010). En este sentido la represión del miR319 inducida por una raza severa de PSTVd en tomate ha sido recientemente asociada a la acumulación de su diana (el gen TCP4) en plantas infectadas por PSTVd, indicando una relación entre la infección viroidal y la ruta regulatoria mediada por este miRNA (Diermann et al., 2010). Esta observación nos lleva a especular sobre la existencia de una relación entre la infección viroidal y las alteraciones fisiológicas que se dan en el huésped. En nuestro trabajo la represión de los miRNAs 165/166, cuyo gradiente controla la polaridad adaxial/abaxial a través de la represión del factor de transcripción de clase III homeodominio zipper de leucina (HDZip III) en maíz (Juarez et al., 2004b), en plantas de pepino infectadas por el HSVd podría estar mimetizando este efecto. De hecho, la posibilidad de que factores de la planta regulados por miRNAs fueran afectados por una 
infección viral y que esto estuviera relacionado directamente con la expresión de síntomas ya ha sido propuesto (Zhang et al., 2006; Bazzini et al., 2009).

En contra de esta tendencia de represión, encontramos cinco miRNAs (miR1515, 398, 408, 397 y 894) con un nivel significativo de acumulación (mas de 3 veces) en planta enferma. Basándonos en homología con otras especies vegetales pudimos inferir que en general estos miRNAs actuarían como reguladores de funciones de desarrollo y repuesta a estrés biótico y abiótico. El miR1515 ha sido recientemente descrito en Medicago truncatula como un regulador de la actividad del homologo de DCL2 en esta especie, enzima implicada en la generación de sRNAs endógenos de 22 y 24 nts (Cuperus et al., 2010; Chen et al., 2010). En consecuencia, su sobrexpresión en plantas infectadas debería estar acompañada por una disminución en los niveles de actividad de DCL2 y por consiguiente de su productos. De manera interesante, los niveles de acumulación de sRNAs de 22 y 24 nts disminuyen considerablemente en planta enferma, sugiriendo que esta situación podría estar siendo inducida por HSVd en pepino. Además, los miRNAs 398 y 408 también se encuentran sobrexpresados en plantas infectadas. De manera interesante ambos miRNAs se sobrexpresan también en plantas de Medicago truncatula sometidas a estrés hídrico (Trindade et al., 2010). Además, la respuesta de sobrexpresión del miRNA 398 podría ser general en infecciones viroidales ya que también se sobreacumulan en plantas de tomate infectadas con una raza severa de PSTVd (Diermann et al., 2010). El resto de miRNAs sobreacumulados (miR397 y miR894) se han relacionado también con el estrés hídrico en plantas (Zhou et al., 2010; Kantar et al., 2011). En su conjunto, todos nuestros datos sugieren que durante la infección se desencadenarían una serie de acontecimientos que alterarían de manera considerable la biogénesis de estos miRNAs. Resultados similares se han descrito recientemente de manera paralela para la interacción PSTVd-tomate (Diermann et al., 2010). En este trabajo los autores describen también que el proceso de infección viroidal tiene un efecto en la población de miRNAs ya que observan tanto disminución como aumento de la acumulación de diversos miRNAs.

Los efectos del proceso de infección en el metabolismo de los miRNAs se observa también a nivel de los miRNAs específicos de pepino. Este es el caso de csaMir7, csaMir8, csaMir9 y csaMir10, que se recuperaron exclusivamente de las librerías de planta enferma, sugiriendo que podrían estar regulados específicamente como repuesta a la infección. Otro hecho a tener en cuenta es que estos miRNAs mostraron también una expresión específica dependiendo del tejido infectado analizado, 
ya que csaMir7 y csaMir8 se recuperaron a partir de floema y csaMir9 y csaMir10 a partir de hoja.

Otra observación que pone de manifiesto que la infección viroidal está afectando de alguna manera a la maquinaria de producción endógena de miRNAs tiene que ver con la fidelidad de la capacidad de procesamiento de los miRNAs. El procesamiento de los miRNAs no es preciso para todas las clases de familias de miRNAs. Generalmente las familias de miRNAs conservadas tienen una fidelidad de precisión mayor que las no conservadas (Ma et al., 2010). Además, la bajada en la fidelidad del procesamiento de miRNAs ha sido asociada a la implicación de DCL4 en la biogénesis de éstos (Rajagopalan et al., 2006). El análisis de la capacidad de procesamiento de los miRNAs descritos en $C$. sativus muestra que en plantas infectadas por HSVd la fidelidad en el procesamiento se encuentra drásticamente alterada, pasando de una eficiencia de $92,56 \%$ en tejidos sanos a $77,76 \%$ en infectados. En base a estos resultados podemos especular que la sobreacumulación de sRNAs de $21 \mathrm{nt}$ en planta infectada podría estar indicando la implicación de DCL4 en el procesamiento de los miRNAs, dando lugar a la generación de miRNAs incorrectamente procesados.

En general, estos resultados si bien preeliminares y pendientes de confirmación a nivel funcional, sugieren que al igual que lo observado en diversas infecciones virales, los viroides podrían también afectar el metabolismo de los miRNAs de la planta y quizás regular mediante esta vía algunos aspectos del proceso de patogénesis inducido en el huésped (figura 18).

\section{Los sRNAs derivados del viroide, posibles efectores del proceso de patogénesis}

Uno de los aspectos fundamentales de la hipótesis de patogénesis viroidal mediada por silenciamiento de RNA sostiene que los vd-sRNAs podrían tener la capacidad de regular, mediante el silenciamiento en trans, la expresión de genes endógenos de la planta (Wang et al., 2004; Gomez et al., 2009). Esta hipótesis está fundamentada en que la carga de los vd-sRNAs en distintos complejos AGO puede facilitar la interacción funcional con los mRNAs del huésped y la cromatina (Mi et al., 2008). En este sentido, se ha demostrado que en ciertas plantas los siRNAs derivados de virus recombinantes pueden inhibir en trans la expresión de transcritos celulares homólogos (Takeda et al., 2008). El uso de códigos informáticos aplicados a la predicción de dianas ha permitido deducir múltiples mRNAs que servirían como posibles dianas para vsiRNAs (Brodersen y Voinnet, 2009; Zhang et al., 2010). No 
obstante, la interacción funcional entre vsiRNAs y mRNAs del huésped solamente ha sido validada experimentalmente para unas cuantas dianas, para las que además no se ha podido determinar ninguna relación con el ciclo infectivo del virus (Moissiard y Voinnet, 2006; Qi et al., 2009). Recientemente, dos trabajos simultaneos han relacionado por primera vez la interferencia de un sRNA derivado del genoma del RNA satélite Y del virus del mosaico del pepino (CMV) con el RNA mensajero de la subunidad I de la Mg protoporfirín quelatasa de su huesped natural Nicotiana tabacum (Shimura et al., 2011; Smith et al., 2011).

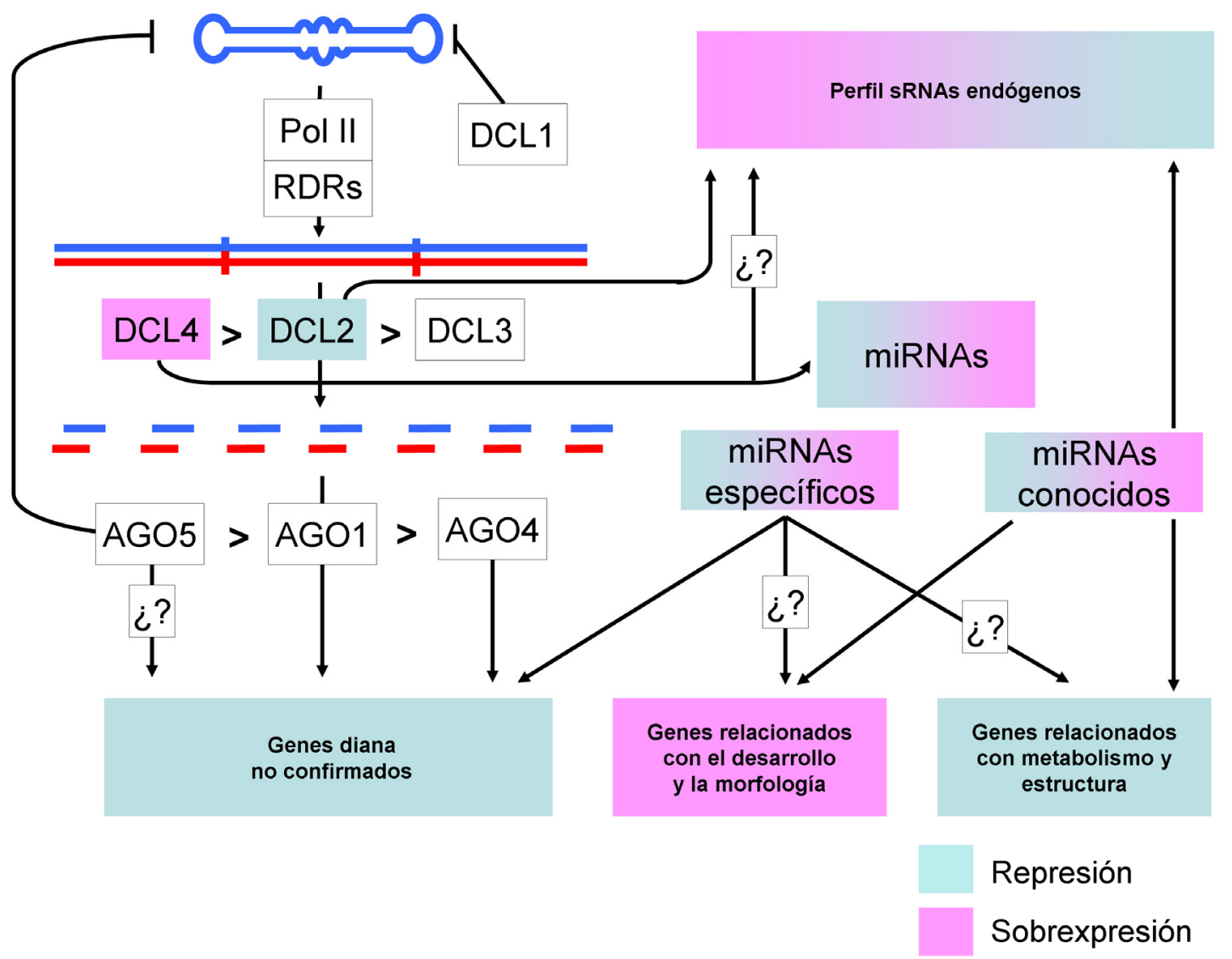

Figura 19. Diagrama del resumen conceptual de la posible relación de la infección viroidal con la maquinaria de silenciamiento de RNA.

En lo que respecta a viroides, la imposibilidad de contar con modelos en los que tanto el genoma del huésped como la población de sRNAs derivados del patógeno estuvieran descritos ha impedido que se realizaran este tipo de aproximaciones, absolutamente necesarias para demostrar la posible relación entre silenciamiento de RNA y la patogénesis inducida por viroides. 
Teniendo en cuenta que nos encontrábamos en la situación ideal de disponer de las dos herramientas necesarias para este tipo de aproximaciones, el genoma de pepino recientemente secuenciado y nuestro conjunto de secuencias de sRNAs derivados del HSVd, decidimos analizar el transcriptoma de pepino en busca de potenciales dianas para nuestros vd-sRNAs, empleando las mismas herramientas bioinformáticas que se emplean en la predicción de dianas para sRNAs endógenos (Moxon et al., 2008). Para nuestra sorpresa encontramos en el genoma de pepino un gran número de potenciales dianas para sRNAs específicos de HSVd, divididos en 219 loci diferentes. Utilizando como referencia homólogos funcionalmente anotados en otras especies vegetales, pudimos inferir el aspecto funcional de los genes de pepino potenciales dianas para los vd-sRNAs. En general, en su gran mayoría las potenciales dianas coincidían con genes relacionados con procesos de desarrollo, metabolismo de proteínas, respuesta a estrés, regulación de la trascripción y biogénesis celular, lo que permitía especular sobre la existencia de una relación directa en la regulación negativa de algunos de estos genes mediada por los vd-sRNAs y los síntomas comúnmente observados en una planta infectada (enanismo, acortamiento de entrenudos, alteración del desarrollo foliar y floral, etc).

Es importante aclarar que reconocemos que este mapa de potenciales dianas para vd-sRNAs en el genoma del huésped no constituye "per se" un hecho probatorio de la existencia de regulación en trans mediada por el viroide. Aún así, este inventario emerge como una valiosa herramienta que posibilitará el paso inicial en el proceso de búsqueda de mRNAs del huésped que podrían estar siendo regulados de manera diferencial por el viroide durante la infección y ser, consecuentemente, los responsables de las alteraciones fenotípicas inducidas en el huésped y reconocidas como síntomas característicos del proceso de patogénesis (figura 19). 


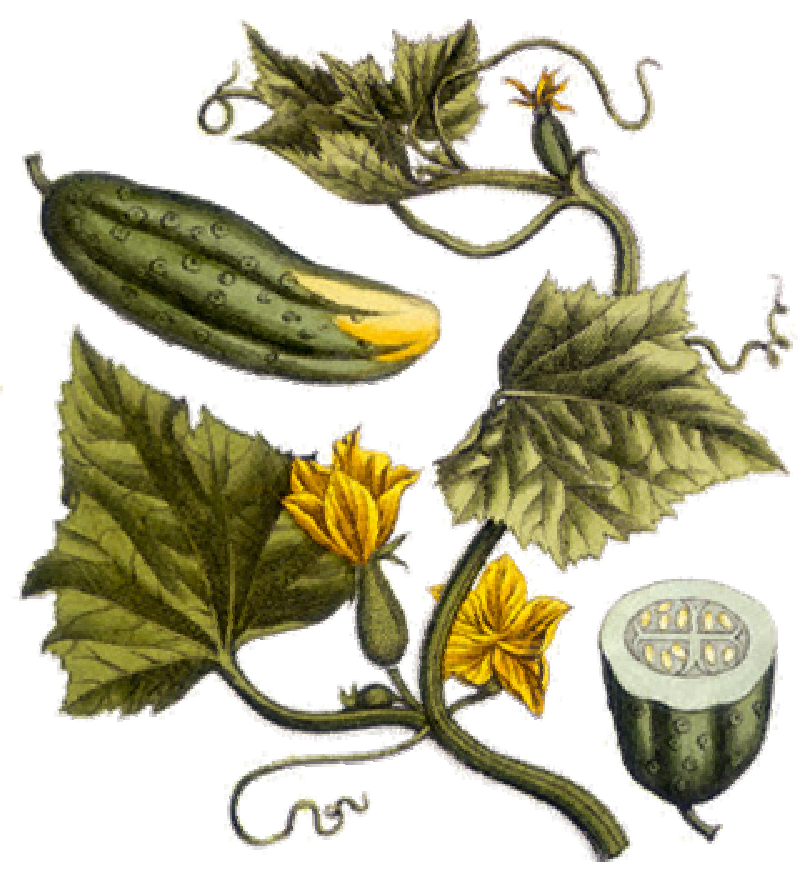

Conclusiones 
En el transcurso de este trabajo de tesis doctoral hemos intentado estudiar la relación existente entre el silenciamiento de RNA y el proceso de patogénesis asociado a una infección viroidal. Partiendo de una serie de datos previos teóricos, hemos aportado evidencia experimental que nos ha permitido enunciar un nuevo modelo de patogénesis, que relaciona la actividad de RDR6 con la expresión de síntomas, aportando las primeras evidencias bioquímicas sobre este tema. Por otra parte y según se desprende de este trabajo los sRNAs derivados del HSVd son originados a partir de un RNA de doble cadena, y no a partir de la forma madura del viroide como se creía hasta este momento, a través de una ruta de biogénesis en la que estaría implicada RDR6 junto con diversas DCLs. Además, la aproximación bioinformática final evidencia la potencialidad de los sRNAs derivados del viroide para actuar en trans contra mRNAs endógenos del huésped, lo que aporta aún más consistencia a la visión global de este modelo de patogénesis. Por otra parte, hemos estudiado además la influencia del viroide sobre la desestabilización en la ruta de biogénesis de miRNAs afectando tanto a la fidelidad de su procesamiento como a la represión o sobrexpresión de éstos. Somos conscientes de que la predicción de potencial targets para vd-sRNAs realizadas en la última parte de este trabajo es solo el punto de partida para continuar avanzando hacia la comprobación total de nuestro modelo de patogénesis. En resumen, las principales conclusiones que se pueden extraer de la presente tesis doctoral son:

1. Se ha comprobado el fenotipo patogénico inducido por el HSVd mediante transgénesis en el huésped experimental $N$. benthamiana, validando de esta manera su empleo como sistema para el estudio del proceso de patogénesis asociado a la infección viroidal.

2. Se ha demostrado que en $N$. benthamiana la expresión de síntomas está asociada con los niveles de silenciamiento de RNA y con la actividad de RDR6 y que es independiente de la acumulación del HSVd en la planta.

3. La obtención de un número similar de secuencias de polaridad positiva y negativa derivadas del viroide, obtenidas por secuenciación masiva a partir de pepino infectado con HSVd, indica que la molécula precursora de la gran mayoría de los vd-sRNAs debe ser un RNA de doble cadena y no la molécula madura como se pensaba al comienzo de esta tesis. Este dsRNA podría ser un intermediario de 
replicación o una molécula generada por la acción de RDRs celulares (posiblemente RDR6, como se ha señalado en el apartado anterior).

4. La distribución de tamaños y la naturaleza del residuo 5' de los vd-sRNAs secuenciados sugieren que DCL4, DCL2 y DCL3 (o los potenciales homólogos existentes en pepino) actuando de forma jerárquica están implicados en su biogénesis.

5. Se ha encontrado una distribución diferencial de vd-sRNAs de 22 nts en el floema de $C$. sativus. Por otra parte, estos sRNAs poseen en su mayoría una secuencia consenso AGAnGCG, lo que sugiere un tráfico diferencial de vd-sRNAs hacia el floema posiblemente dependiente de tamaño y secuencia.

6. Se ha establecido la población de miRNAs conservados y no conservados en $C$. sativus. Además hemos descrito 10 nuevos miRNAs posiblemente específicos de especie.

7. Se ha observado que la infección de HSVd en Cucumis sativus induce un incremento en el número de secuencias de sRNAs de 21 nucleótidos, la disminución de la acumulación de los miRNAs 166, 393, 319, 390, 165, 156, 827, 396, 172, 858, 164 y 160 y un aumento en la acumulación de los miRNAs 398, 408, 397, 894 y 1515 y de los miRNAs específicos de pepino csa-miR5, 7 y 8. Además, se ha observado una reducción en la fidelidad de la precisión de procesamiento de miRNAs en plantas infectadas, hecho posiblemente relacionado con la implicación de DCL4 en el procesado de estos, lo que sugiere que de alguna manera el proceso de infección altera las redes reguladoras mediadas por estos sRNAs endógenos.

8. Se ha demostrado la potencialidad de los vd-sRNAs de HSVd de actuar en trans sobre mRNAs endógenos de C. sativus. En concreto se han identificado en el transcriptoma de pepino 218 posibles dianas susceptibles de ser silenciadas por sRNAs derivados del viroide durante la infección, que podrían explicar la aparición de síntomas en la planta. 


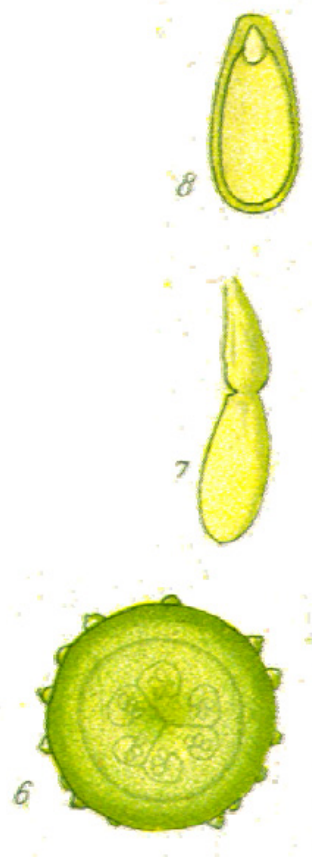

Bibliografía 
Adenot, X., T. Elmayan, D. Lauressergues, S. Boutet, N. Bouche, V. Gasciolli y H. Vaucheret (2006). "DRB4-dependent TAS3 trans-acting siRNAs control leaf morphology through AGO7." Current Biology 16(9): 927-932.

Allen, E., Z. Xie, A. M. Gustafson y J. C. Carrington (2005). "microRNA-directed phasing during trans-acting siRNA biogenesis in plants." Cell 121(2): 207-221.

Amari, K., G. Gomez, A. Myrta, B. Di Terlizzi y V. Pallas (2001). "The molecular characterization of 16 new sequence variants of Hop stunt viroid reveals the existence of invariable regions and a conserved hammerhead-like structure on the viroid molecule." Journal of General Virology 82(Pt 4): 953-962.

Ambros, S., C. Hernandez, J. C. Desvignes y R. Flores (1998). "Genomic structure of three phenotypically different isolates of peach latent mosaic viroid: implications of the existence of constraints limiting the heterogeneity of viroid quasispecies." Journal of Virology 72(9): 7397-7406.

Ambros, S., C. Hernandez y R. Flores (1999). "Rapid generation of genetic heterogeneity in progenies from individual cDNA clones of peach latent mosaic viroid in its natural host." Journal of General Virology 80 ( Pt 8): 2239-2252.

Ambros, V. (2004). "The functions of animal microRNAs." Nature 431(7006): 350-355.

Anandalakshmi, R., G. J. Pruss, X. Ge, R. Marathe, A. C. Mallory, T. H. Smith y V. B. Vance (1998). "A viral suppressor of gene silencing in plants." Proceedings of the National Academy of Sciences USA 95(22): 13079-13084.

Astruc, N., J. F. Marcos, G. Macquaire, T. Candresse y V. Pallas (1996). "Studies on the diagnosis of hop stunt viroid in fruit trees: Identification of new hosts and application of a nucleic acid extraction procedure based on non-organic solvents." European Journal of Plant Pathology 102(9): 837-846.

Aukerman, M. J. y H. Sakai (2003). "Regulation of flowering time and floral organ identity by a MicroRNA and its APETALA2-like target genes." Plant Cell 15(11): 2730-2741.

Bagasra, O. y K. R. Prilliman (2004). "RNA interference: the molecular immune system." Journal of Molecular Histology 35(6): 545-553.

Bagga, S., J. Bracht, S. Hunter, K. Massirer, J. Holtz, R. Eachus y A. E. Pasquinelli (2005). "Regulation by let-7 and lin-4 miRNAs results in target mRNA degradation." Cell 122(4): 553-563.

Baker, C. C., P. Sieber, F. Wellmer y E. M. Meyerowitz (2005). "The early extra petals1 mutant uncovers a role for microRNA miR164c in regulating petal number in Arabidopsis." Current Biology 15(4): 303-315.

Bartel, D. P. (2004). "MicroRNAs: genomics, biogenesis, mechanism, and function." Cell 116(2): 281-297.

Baulcombe, D. (2004). "RNA silencing in plants." Nature 431(7006): 356-363.

Bazzini, A. A., N. I. Almasia, C. A. Manacorda, V. C. Mongelli, G. Conti, G. A. Maroniche, M. C. Rodriguez, A. J. Distefano, H. E. Hopp, M. del Vas y S. 
Asurmendi (2009). "Virus infection elevates transcriptional activity of miR164a promoter in plants." BMC Plant Biology 9: 152.

Bazzini, A. A., H. E. Hopp, R. N. Beachy y S. Asurmendi (2007). "Infection and coaccumulation of tobacco mosaic virus proteins alter microRNA levels, correlating with symptom and plant development." Proceedings of the National Academy of Sciences USA 104(29): 12157-12162.

Beauclair, L., A. Yu y N. Bouche (2010). "microRNA-directed cleavage and translational repression of the copper chaperone for superoxide dismutase mRNA in Arabidopsis." Plant Journal 62(3): 454-462.

Bendahmane, A., M. Querci, K. Kanyuka y D. C. Baulcombe (2000). "Agrobacterium transient expression system as a tool for the isolation of disease resistance genes: application to the Rx2 locus in potato." Plant Journal 21(1): 73-81.

Bernstein, E., A. A. Caudy, S. M. Hammond y G. J. Hannon (2001). "Role for a bidentate ribonuclease in the initiation step of RNA interference." Nature 409(6818): 363-366.

Blevins, T., R. Rajeswaran, P. V. Shivaprasad, D. Beknazariants, A. Si-Ammour, H. S. Park, F. Vazquez, D. Robertson, F. Meins, Jr., T. Hohn y M. M. Pooggin (2006). "Four plant Dicers mediate viral small RNA biogenesis and DNA virus induced silencing." Nucleic Acids Research 34(21): 6233-6246.

Bolduc, F., C. Hoareau, P. St-Pierre y J. P. Perreault (2010). "In-depth sequencing of the siRNAs associated with peach latent mosaic viroid infection." BMC Molecular Biology 11: 16.

Bonfiglioli, R. G., D. R. Webb y R. H. Symons (1996). "Tissue and intra-cellular distribution of coconut cadang cadang viroid and citrus exocortis viroid determined by in situ hybridization and confocal laser scanning and transmission electron microscopy." Plant Journal 9(4): 457-465.

Borsani, O., J. Zhu, P. E. Verslues, R. Sunkar y J. K. Zhu (2005). "Endogenous siRNAs derived from a pair of natural cis-antisense transcripts regulate salt tolerance in Arabidopsis." Cell 123(7): 1279-1291.

Bouche, N., D. Lauressergues, V. Gasciolli y H. Vaucheret (2006). "An antagonistic function for Arabidopsis DCL2 in development and a new function for DCL4 in generating viral siRNAs." EMBO Journal 25(14): 3347-3356.

Branch, A. D. y E. Dickson (1980). "Tomato DNA contains no detectable regions complementary to potato spindle tuber viroid as assayed by Southern hybridization." Virology 104(1): 10-26.

Branch, A. D. y H. D. Robertson (1984). "A replication cycle for viroids and other small RNAs." Science 223(4635): 450-455.

Brigneti, G., O. Voinnet, W. X. Li, L. H. Ji, S. W. Ding y D. C. Baulcombe (1998). "Viral pathogenicity determinants are suppressors of transgene silencing in Nicotiana benthamiana." EMBO Journal 17(22): 6739-6746. 
Brodersen, P., L. Sakvarelidze-Achard, M. Bruun-Rasmussen, P. Dunoyer, Y. Y. Yamamoto, L. Sieburth y O. Voinnet (2008). "Widespread translational inhibition by plant miRNAs and siRNAs." Science 320(5880): 1185-1190.

Brodersen, P. y O. Voinnet (2006). "The diversity of RNA silencing pathways in plants." Trends in Genetics 22(5): 268-280.

Brodersen, P. y O. Voinnet (2009). "Revisiting the principles of microRNA target recognition and mode of action." Nature Reviews Molecular Cell Biology 10(2): 141-148.

Brosnan, C. A., N. Mitter, M. Christie, N. A. Smith, P. M. Waterhouse y B. J. Carroll (2007). "Nuclear gene silencing directs reception of long-distance mRNA silencing in Arabidopsis." Proceedings of the National Academy of Sciences USA 104(37): 14741-14746.

Bussiere, F., J. Lehoux, D. A. Thompson, L. J. Skrzeczkowski y J. Perreault (1999). "Subcellular localization and rolling circle replication of peach latent mosaic viroid: hallmarks of group A viroids." Journal of Virology 73(8): 6353-6360.

Cañizares, M. C., J. F. Marcos y V. Pallás (1999). "Molecular Characterization of an Almond Isolate of Hop Stunt Viroid (HSVd) and Conditions for Eliminating Spurious Hybridization in its Diagnosis in Almond Samples." European Journal of Plant Pathology 105(6): 553-558.

Caplen, N. J., S. Parrish, F. Imani, A. Fire y R. A. Morgan (2001). "Specific inhibition of gene expression by small double-stranded RNAs in invertebrate and vertebrate systems." Proceedings of the National Academy of Sciences USA 98(17): 97429747.

Carbonell, A., A. E. Martinez de Alba, R. Flores y S. Gago (2008). "Double-stranded RNA interferes in a sequence-specific manner with the infection of representative members of the two viroid families." Virology 371(1): 44-53.

Cillo, F., T. Mascia, M. M. Pasciuto y D. Gallitelli (2009). "Differential effects of mild and severe Cucumber mosaic virus strains in the perturbation of MicroRNAregulated gene expression in tomato map to the 3' sequence of RNA 2." Molecular Plant-Microbe Interactions 22(10): 1239-1249.

Coetzee, B., M. J. Freeborough, H. J. Maree, J. M. Celton, D. J. Rees y J. T. Burger (2010). "Deep sequencing analysis of viruses infecting grapevines: Virome of a vineyard." Virology 400(2): 157-163.

Conejero, V. (2003). "Viroids and gene silencing". En: Viroids. Ed. Hadidi A., Flores R., Randles JW., Semancik JS. CSIRO Publising, Collingwood, 67-70.

Cullen, B. R. (2006). "Viruses and microRNAs." Nature Genetics 38 Suppl: S25-30.

Cuperus, J. T., A. Carbonell, N. Fahlgren, H. Garcia-Ruiz, R. T. Burke, A. Takeda, C. M. Sullivan, S. D. Gilbert, T. A. Montgomery y J. C. Carrington (2010). "Unique functionality of 22-nt miRNAs in triggering RDR6-dependent siRNA biogenesis 
from target transcripts in Arabidopsis." Nature Structural \& Molecular Biology 17(8): 997-1003.

Cuperus, J. T., N. Fahlgren y J. C. Carrington (2011). "Evolution and functional diversification of MIRNA genes." Plant Cell 23(2): 431-442.

Curaba, J. y X. Chen (2008). "Biochemical activities of Arabidopsis RNA-dependent RNA polymerase 6." Journal of Biological Chemistry 283(6): 3059-3066.

Chang, J., P. Provost y J. M. Taylor (2003). "Resistance of human hepatitis delta virus RNAs to dicer activity." Journal of Virology 77(22): 11910-11917.

Chapman, E. J. y J. C. Carrington (2007). "Specialization and evolution of endogenous small RNA pathways." Nature Reviews Genetics 8(11): 884-896.

Chellappan, P., R. Vanitharani, J. Pita y C. M. Fauquet (2004). "Short interfering RNA accumulation correlates with host recovery in DNA virus-infected hosts, and gene silencing targets specific viral sequences." Journal of Virology 78(14): 7465-7477.

Chen, H. M., L. T. Chen, K. Patel, Y. H. Li, D. C. Baulcombe y S. H. Wu (2010). "22Nucleotide RNAs trigger secondary siRNA biogenesis in plants." Proceedings of the National Academy of Sciences USA 107(34): 15269-15274.

Chen, X. (2004). "A microRNA as a translational repressor of APETALA2 in Arabidopsis flower development." Science 303(5666): 2022-2025.

Chen, X. (2005). "MicroRNA biogenesis and function in plants." FEBS Letters 579(26): 5923-5931.

Chen, X. (2009). "Small RNAs and their roles in plant development." Annual Review of Cell and Developmental Biology 25: 21-44.

Dalmay, T., A. Hamilton, S. Rudd, S. Angell y D. C. Baulcombe (2000). "An RNAdependent RNA polymerase gene in Arabidopsis is required for posttranscriptional gene silencing mediated by a transgene but not by a virus." Cell 101(5): 543-553.

Daros, J. A. y R. Flores (2004). "Arabidopsis thaliana has the enzymatic machinery for replicating representative viroid species of the family Pospiviroidae." Proceedings of the National Academy of Sciences USA 101(17): 6792-6797.

Daros, J. A., J. F. Marcos, C. Hernandez y R. Flores (1994). "Replication of avocado sunblotch viroid: evidence for a symmetric pathway with two rolling circles and hammerhead ribozyme processing." Proceedings of the National Academy of Sciences USA 91(26): 12813-12817.

De la Peña, M. y R. Flores (2002). "Chrysanthemum chlorotic mottle viroid RNA: dissection of the pathogenicity determinant and comparative fitness of symptomatic and non-symptomatic variants." Journal of Molecular Biology 321(3): 411-421.

De la Peña, M., B. Navarro y R. Flores (1999). "Mapping the molecular determinant of pathogenicity in a hammerhead viroid: a tetraloop within the in vivo branched 
RNA conformation." Proceedings of the National Academy of Sciences USA 96(17): 9960-9965.

Deleris, A., J. Gallego-Bartolome, J. Bao, K. D. Kasschau, J. C. Carrington y O. Voinnet (2006). "Hierarchical action and inhibition of plant Dicer-like proteins in antiviral defense." Science 313(5783): 68-71.

Delgado, S., A. E. Martinez de Alba, C. Hernandez y R. Flores (2005). "A short doublestranded RNA motif of Peach latent mosaic viroid contains the initiation and the self-cleavage sites of both polarity strands." Journal of Virology 79(20): 1293412943.

Denti, M. A., A. Boutla, M. Tsagris y M. Tabler (2004). "Short interfering RNAs specific for potato spindle tuber viroid are found in the cytoplasm but not in the nucleus." Plant Journal 37(5): 762-769.

Di Serio, F., A. Gisel, B. Navarro, S. Delgado, A. E. Martinez de Alba, G. Donvito y R. Flores (2009). "Deep sequencing of the small RNAs derived from two symptomatic variants of a chloroplastic viroid: implications for their genesis and for pathogenesis." PLoS ONE 4(10): e7539.

Di Serio, F., A. E. Martinez de Alba, B. Navarro, A. Gisel y R. Flores (2010). "RNAdependent RNA polymerase 6 delays accumulation and precludes meristem invasion of a viroid that replicates in the nucleus." Journal of Virology 84(5): 2477-2489.

Diaz-Pendon, J. A., F. Li, W. X. Li y S. W. Ding (2007). "Suppression of antiviral silencing by cucumber mosaic virus $2 b$ protein in Arabidopsis is associated with drastically reduced accumulation of three classes of viral small interfering RNAs." Plant Cell 19(6): 2053-2063.

Diener, T. O. (1971a). "Potato spindle tuber "virus". IV. A replicating, low molecular weight RNA." Virology 45(2): 411-428.

Diener, T. O. (1971b). "Potato spindle tuber virus: a plant virus with properties of a free nucleic acid. 3. Subcellular location of PSTV-RNA and the question of whether virions exist in extracts or in situ." Virology 43(1): 75-89.

Diener, T. O. (1981). "Are viroids escaped introns?" Proceedings of the National Academy of Sciences USA 78(8): 5014-5015.

Diener, T. O. (1989). "Circular RNAs: relics of precellular evolution?" Proceedings of the National Academy of Sciences USA 86(23): 9370-9374.

Diener, T. O. (2001). "The viroid: biological oddity or evolutionary fossil?" Advances in Virus Research 57: 137-184.

Diener, T. O. y R. H. Lawson (1973). "Chrysanthemum stunt: a viroid disease." Virology 51(1): 94-101.

Diener, T. O. y W. B. Raymer (1967). "Potato spindle tuber virus: a plant virus with properties of a free nucleic acid." Science 158(799): 378-381. 
Diener, T. O., D. R. Smith, R. H. Hammond, G. Albanese, R. Larosa y M. Davino (1988). "Citrus-B viroid identified as a strain of hop stunt viroid." Plant Disease 72(8): 691-693.

Diermann, N., J. Matousek, M. Junge, D. Riesner y G. Steger (2010). "Characterization of plant miRNAs and small RNAs derived from potato spindle tuber viroid (PSTVd) in infected tomato." Biological Chemistry 391(12): 1379-1390.

Ding, B. (2009). "The biology of viroid-host interactions." Annual Review of Phytopathology 47: 105-131.

Ding, B. y A. Itaya (2007). "Viroid: a useful model for studying the basic principles of infection and RNA biology." Molecular Plant-Microbe Interactions 20(1): 7-20.

Ding, S. W. y O. Voinnet (2007). "Antiviral immunity directed by small RNAs." Cell 130(3): 413-426.

Dlakic, M. (2006). "DUF283 domain of Dicer proteins has a double-stranded RNAbinding fold." Bioinformatics 22(22): 2711-2714.

Donaire, L., D. Barajas, B. Martinez-Garcia, L. Martinez-Priego, I. Pagan y C. Llave (2008). "Structural and genetic requirements for the biogenesis of tobacco rattle virus-derived small interfering RNAs." Journal of Virology 82(11): 5167-5177.

Donaire, L., Y. Wang, D. Gonzalez-Ibeas, K. F. Mayer, M. A. Aranda y C. Llave (2009). "Deep-sequencing of plant viral small RNAs reveals effective and widespread targeting of viral genomes." Virology 392(2): 203-214.

Du, T. y P. D. Zamore (2005). "microPrimer: the biogenesis and function of microRNA." Development 132(21): 4645-4652.

Dunoyer, P., C. A. Brosnan, G. Schott, Y. Wang, F. Jay, A. Alioua, C. Himber y O. Voinnet (2010b). "An endogenous, systemic RNAi pathway in plants." EMBO Journal 29(10): 1699-1712.

Dunoyer, P., C. Himber y O. Voinnet (2005). "DICER-LIKE 4 is required for RNA interference and produces the 21-nucleotide small interfering RNA component of the plant cell-to-cell silencing signal." Nature Genetics 37(12): 1356-1360.

Dunoyer, P., C. H. Lecellier, E. A. Parizotto, C. Himber y O. Voinnet (2004). "Probing the microRNA and small interfering RNA pathways with virus-encoded suppressors of RNA silencing." Plant Cell 16(5): 1235-1250.

Dunoyer, P., G. Schott, C. Himber, D. Meyer, A. Takeda, J. C. Carrington y O. Voinnet (2010a). "Small RNA duplexes function as mobile silencing signals between plant cells." Science 328(5980): 912-916.

Dunoyer, P. y O. Voinnet (2005). "The complex interplay between plant viruses and host RNA-silencing pathways." Current Opinion in Plant Biology 8(4): 415-423.

Eamens, A., M. B. Wang, N. A. Smith y P. M. Waterhouse (2008). "RNA silencing in plants: yesterday, today, and tomorrow." Plant Physiology 147(2): 456-468. 
Elbashir, S. M., J. Harborth, W. Lendeckel, A. Yalcin, K. Weber y T. Tuschl (2001). "Duplexes of 21-nucleotide RNAs mediate RNA interference in cultured mammalian cells." Nature 411(6836): 494-498.

Elena, S. F., G. Gomez y J. A. Daros (2009). "Evolutionary Constraints to Viroid Evolution." Viruses-Basel 1(2): 241-254.

Emery, J. F., S. K. Floyd, J. Alvarez, Y. Eshed, N. P. Hawker, A. Izhaki, S. F. Baum y J. L. Bowman (2003). "Radial patterning of Arabidopsis shoots by class III HD-ZIP and KANADI genes." Current Biology 13(20): 1768-1774.

Escobar, C., L. E. Hernandez, A. Jimenez, G. Creissen, M. T. Ruiz y P. M. Mullineaux (2003). "Transient expression of Arabidopsis thaliana ascorbate peroxidase 3 in Nicotiana benthamiana plants infected with recombinant potato virus X." Plant Cell Reports 21(7): 699-704.

Fadda, Z., J. A. Daros, R. Flores y N. Duran-Vila (2003). "Identification in eggplant of a variant of citrus exocortis viroid (CEVd) with a 96 nucleotide duplication in the right terminal region of the rod-like secondary structure." Virus Research 97(2): 145-149.

Fahlgren, N., M. D. Howell, K. D. Kasschau, E. J. Chapman, C. M. Sullivan, J. S. Cumbie, S. A. Givan, T. F. Law, S. R. Grant, J. L. Dangl y J. C. Carrington (2007). "High-throughput sequencing of Arabidopsis microRNAs: evidence for frequent birth and death of MIRNA genes." PLoS ONE 2(2): e219.

Fahlgren, N., T. A. Montgomery, M. D. Howell, E. Allen, S. K. Dvorak, A. L. Alexander y J. C. Carrington (2006). "Regulation of AUXIN RESPONSE FACTOR3 by TAS3 ta-siRNA affects developmental timing and patterning in Arabidopsis." Current Biology 16(9): 939-944.

Fang, Y. y D. L. Spector (2007). "Identification of nuclear dicing bodies containing proteins for microRNA biogenesis in living Arabidopsis plants." Current Biology 17(9): 818-823.

Fernandez-Calvino, L., Faulkner, C., y A.Maule (2011). "Plasmodesmata as active conduits for virus cell-to-cell movement". En: Recent Advances in Plant Virology. Ed. Caranta, C., Aranda, MA., Tepfer, M. and JJ. López-Moya. Caister Academic Press, Norfolk.

Fire, A., S. Xu, M. K. Montgomery, S. A. Kostas, S. E. Driver y C. C. Mello (1998). "Potent and specific genetic interference by double-stranded RNA in Caenorhabditis elegans." Nature 391(6669): 806-811.

Flores, R., C. Hernandez, A. E. Martinez de Alba, J. A. Daros y F. Di Serio (2005). "Viroids and viroid-host interactions." Annual Review of Phytopathology 43: 117139.

Fusaro, A. F., L. Matthew, N. A. Smith, S. J. Curtin, J. Dedic-Hagan, G. A. Ellacott, J. M. Watson, M. B. Wang, C. Brosnan, B. J. Carroll y P. M. Waterhouse (2006). 
"RNA interference-inducing hairpin RNAs in plants act through the viral defence pathway." EMBO Reports 7(11): 1168-1175.

Garcia, D., S. A. Collier, M. E. Byrne y R. A. Martienssen (2006). "Specification of leaf polarity in Arabidopsis via the trans-acting siRNA pathway." Current Biology 16(9): 933-938.

Gasciolli, V., A. C. Mallory, D. P. Bartel y H. Vaucheret (2005). "Partially redundant functions of Arabidopsis DICER-like enzymes and a role for DCL4 in producing trans-acting siRNAs." Current Biology 15(16): 1494-1500.

Gitlin, L., J. K. Stone y R. Andino (2005). "Poliovirus escape from RNA interference: short interfering RNA-target recognition and implications for therapeutic approaches." Journal of Virology 79(2): 1027-1035.

Gomez, G., G. Martinez y V. Pallas (2009). "Interplay between viroid-induced pathogenesis and RNA silencing pathways." Trends in Plant Science 14(5): 264269.

Gomez, G., G. Martinez y V. Pallas (2008). "Viroid-induced symptoms in Nicotiana benthamiana plants are dependent on RDR6 activity." Plant Physiology 148(1): 414-423.

Gomez, G. y V. Pallas (2007). "Mature monomeric forms of Hop stunt viroid resist RNA silencing in transgenic plants." Plant Journal 51(6): 1041-1049.

Gomez, G. y V. Pallas (2006). "Hop stunt viroid is processed and translocated in transgenic Nicotiana benthamiana plants." Molecular Plant Pathology 7(6): 511517.

Gong, P., F. Xie, B. Zhang y E. J. Perkins (2010). "In silico identification of conserved microRNAs and their target transcripts from expressed sequence tags of three earthworm species." Computational Biology and Chemistry 34(5-6): 313-319.

Goodin, M. M., R. G. Dietzgen, D. Schichnes, S. Ruzin y A. O. Jackson (2002). "pGD vectors: versatile tools for the expression of green and red fluorescent protein fusions in agroinfiltrated plant leaves." Plant Journal 31(3): 375-383.

Goodin, M. M., D. Zaitlin, R. A. Naidu y S. A. Lommel (2008). "Nicotiana benthamiana: its history and future as a model for plant-pathogen interactions." Molecular Plant-Microbe Interactions 21(8): 1015-1026.

Grill, L. K. y J. S. Semancik (1978). "RNA sequences complementary to citrus exocortis viroid in nucleic acid preparations from infected Gynura aurantiaca." Proceedings of the National Academy of Sciences USA 75(2): 896-900.

Gross, H. J., H. Domdey, C. Lossow, P. Jank, M. Raba, H. Alberty y H. L. Sanger (1978). "Nucleotide sequence and secondary structure of potato spindle tuber viroid." Nature 273(5659): 203-208.

Guo, H. S., Q. Xie, J. F. Fei y N. H. Chua (2005). "MicroRNA directs mRNA cleavage of the transcription factor NAC1 to downregulate auxin signals for arabidopsis lateral root development." Plant Cell 17(5): 1376-1386. 
Hafner, M., P. Landgraf, J. Ludwig, A. Rice, T. Ojo, C. Lin, D. Holoch, C. Lim y T. Tuschl (2008). "Identification of microRNAs and other small regulatory RNAs using cDNA library sequencing." Methods 44(1): 3-12.

Hamilton, A., O. Voinnet, L. Chappell y D. Baulcombe (2002). "Two classes of short interfering RNA in RNA silencing." EMBO Journal 21(17): 4671-4679.

Han, M. H., S. Goud, L. Song y N. Fedoroff (2004). "The Arabidopsis double-stranded RNA-binding protein HYL1 plays a role in microRNA-mediated gene regulation." Proceedings of the National Academy of Sciences USA 101(4): 1093-1098.

Harders, J., N. Lukacs, M. Robert-Nicoud, T. M. Jovin y D. Riesner (1989). "Imaging of viroids in nuclei from tomato leaf tissue by in situ hybridization and confocal laser scanning microscopy." EMBO Journal 8(13): 3941-3949.

Hassan, M., G. Gomez, V. Pallas, A. Myrta y P. Rysanek (2009). "Simultaneous detection and genetic variability of stone fruit viroids in the Czech Republic." European Journal of Plant Pathology 124(2): 363-368.

He, X. F., Y. Y. Fang, L. Feng y H. S. Guo (2008). "Characterization of conserved and novel microRNAs and their targets, including a TuMV-induced TIR-NBS-LRR class R gene-derived novel miRNA in Brassica." FEBS Letters 582(16): 24452452.

Herr, A. J. y D. C. Baulcombe (2004). "RNA silencing pathways in plants." Cold Spring Harbor Symposia on Quantitative Biology 69: 363-370.

Herr, A. J., M. B. Jensen, T. Dalmay y D. C. Baulcombe (2005). "RNA polymerase IV directs silencing of endogenous DNA." Science 308(5718): 118-120.

Himber, C., P. Dunoyer, G. Moissiard, C. Ritzenthaler y O. Voinnet (2003). "Transitivity-dependent and -independent cell-to-cell movement of RNA silencing." EMBO Journal 22(17): 4523-4533.

Hiraguri, A., R. Itoh, N. Kondo, Y. Nomura, D. Aizawa, Y. Murai, H. Koiwa, M. Seki, K. Shinozaki y T. Fukuhara (2005). "Specific interactions between Dicer-like proteins and HYL1/DRB-family dsRNA-binding proteins in Arabidopsis thaliana." Plant Molecular Biology 57(2): 173-188.

Ho, T., H. Wang, D. Pallett y T. Dalmay (2007). "Evidence for targeting common siRNA hotspots and GC preference by plant Dicer-like proteins." FEBS Letters 581(17): 3267-3272.

Hoffer, P., S. Ivashuta, O. Pontes, A. Vitins, C. Pikaard, A. Mroczka, N. Wagner y T. Voelker (2011). "Posttranscriptional gene silencing in nuclei." Proceedings of the National Academy of Sciences USA 108(1): 409-414.

Hsu, Y. H., W. Chen y R. A. Owens (1995). "Nucleotide-sequence of a Hop stunt viroid variant isolated from citrus growing in Taiwan." Virus Genes 9(2): 193-195.

Huang, S., R. Li, Z. Zhang, L. Li et al. (2009). "The genome of the cucumber, Cucumis sativus L." Nature Genetics 41(12): 1275-1281. 
Hutchins, C. J., P. Keese, J. E. Visvader, P. D. Rathjen, J. L. McInnes y R. H. Symons (1985). "Comparison of multimeric plus and minus forms of viroids and virusoids." Plant Molecular Biology 4(5): 293-304.

Hutvagner, G. y M. J. Simard (2008). "Argonaute proteins: key players in RNA silencing." Nature Reviews Molecular Cell Biology 9(1): 22-32.

Ishikawa, M., T. Meshi, T. Ohno, Y. Okada, T. Sano, I. Ueda y E. Shikata (1984). "A revised replication cycle for viroids: the role of longer than unit length RNA in viroid replication." Molecular and General Genetics 196(3): 421-428.

Itaya, A., A. Folimonov, Y. Matsuda, R. S. Nelson y B. Ding (2001). "Potato spindle tuber viroid as inducer of RNA silencing in infected tomato." Molecular PlantMicrobe Interactions 14(11): 1332-1334.

Itaya, A., X. Zhong, R. Bundschuh, Y. Qi, Y. Wang, R. Takeda, A. R. Harris, C. Molina, R. S. Nelson y B. Ding (2007). "A structured viroid RNA serves as a substrate for dicer-like cleavage to produce biologically active small RNAs but is resistant to RNA-induced silencing complex-mediated degradation." Journal of Virology 81(6): 2980-2994.

Jagadeeswaran, G., A. Saini y R. Sunkar (2009). "Biotic and abiotic stress downregulate miR398 expression in Arabidopsis." Planta 229(4): 1009-1014.

Jamalkandi, S. A. y A. Masoudi-Nejad (2009). "Reconstruction of Arabidopsis thaliana fully integrated small RNA pathway." Functional \& Integrative Genomics 9(4): 419-432.

Jin, H., V. Vacic, T. Girke, S. Lonardi y J. K. Zhu (2008). "Small RNAs and the regulation of cis-natural antisense transcripts in Arabidopsis." BMC Molecular Biology 9: 6.

Jones-Rhoades, M. W. y D. P. Bartel (2004). "Computational identification of plant microRNAs and their targets, including a stress-induced miRNA." Molecular Cell 14(6): 787-799.

Juarez, M. T., J. S. Kui, J. Thomas, B. A. Heller y M. C. Timmermans (2004a). "microRNA-mediated repression of rolled leafl specifies maize leaf polarity." Nature 428(6978): 84-88.

Juarez, M. T., R. W. Twigg y M. C. Timmermans (2004b). "Specification of adaxial cell fate during maize leaf development." Development 131(18): 4533-4544.

Kalantidis, K. (2004). "Grafting the way to the systemic silencing signal in plants." PLoS Biology 2(8): E224.

Kalantidis, K., H. T. Schumacher, T. Alexiadis y J. M. Helm (2008). "RNA silencing movement in plants." Biologie Cellulaire 100(1): 13-26.

Kantar, M., S. J. Lucas y H. Budak (2011). "miRNA expression patterns of Triticum dicoccoides in response to shock drought stress." Planta 233(3): 471-484.

Kasschau, K. D. y J. C. Carrington (1998). "A counterdefensive strategy of plant viruses: suppression of posttranscriptional gene silencing." Cell 95(4): 461-470. 
Kasschau, K. D., N. Fahlgren, E. J. Chapman, C. M. Sullivan, J. S. Cumbie, S. A. Givan y J. C. Carrington (2007). "Genome-wide profiling and analysis of Arabidopsis siRNAs." PLoS Biology 5(3): e57.

Kasschau, K. D., Z. Xie, E. Allen, C. Llave, E. J. Chapman, K. A. Krizan y J. C. Carrington (2003). "P1/HC-Pro, a viral suppressor of RNA silencing, interferes with Arabidopsis development and miRNA unction." Developmental Cell 4(2): 205-217.

Katiyar-Agarwal, S., S. Gao, A. Vivian-Smith y H. Jin (2007). "A novel class of bacteria-induced small RNAs in Arabidopsis." Genes \& Development 21(23): 3123-3134.

Katiyar-Agarwal, S., R. Morgan, D. Dahlbeck, O. Borsani, A. Villegas, Jr., J. K. Zhu, B. J. Staskawicz y H. Jin (2006). "A pathogen-inducible endogenous siRNA in plant immunity." Proceedings of the National Academy of Sciences USA 103(47): 18002-18007.

Keese, P. y R. H. Symons (1985). "Domains in viroids: evidence of intermolecular RNA rearrangements and their contribution to viroid evolution." Proceedings of the National Academy of Sciences USA 82(14): 4582-4586.

Kidner, C. A. y R. A. Martienssen (2003). "Macro effects of microRNAs in plants." Trends in Genetics 19(1): 13-16.

Kidner, C. A. y R. A. Martienssen (2005). "The developmental role of microRNA in plants." Current Opinion in Plant Biology 8(1): 38-44.

Kim, V. N. (2005a). "MicroRNA biogenesis: coordinated cropping and dicing." Nature Reviews Molecular Cell Biology 6(5): 376-385.

Kim, V. N. (2005b). "Small RNAs: classification, biogenesis, and function." Molecules and Cells 19(1): 1-15.

Kini, H. K. y S. P. Walton (2007). "In vitro binding of single-stranded RNA by human Dicer." FEBS Letters 581(29): 5611-5616.

Kofalvi, S. A., J. F. Marcos, M. C. Canizares, V. Pallas y T. Candresse (1997). "Hop stunt viroid (HSVd) sequence variants from Prunus species: evidence for recombination between HSVd isolates." Journal of General Virology 78 ( Pt 12): 3177-3186.

Kurihara, Y., Y. Takashi y Y. Watanabe (2006). "The interaction between DCL1 and HYL1 is important for efficient and precise processing of pri-miRNA in plant microRNA biogenesis." RNA 12(2): 206-212.

Kurihara, Y. y Y. Watanabe (2004). "Arabidopsis micro-RNA biogenesis through Dicer-like 1 protein functions." Proceedings of the National Academy of Sciences USA 101(34): 12753-12758.

Landry, P. y J. P. Perreault (2005). "Identification of a peach latent mosaic viroid hairpin able to act as a Dicer-like substrate." Journal of Virology 79(10): 65406543. 
Lee, R. C., R. L. Feinbaum y V. Ambros (1993). "The C. elegans heterochronic gene lin-4 encodes small RNAs with antisense complementarity to lin-14." Cell 75(5): 843-854.

Lim, L. P., N. C. Lau, P. Garrett-Engele, A. Grimson, J. M. Schelter, J. Castle, D. P. Bartel, P. S. Linsley y J. M. Johnson (2005). "Microarray analysis shows that some microRNAs downregulate large numbers of target mRNAs." Nature 433(7027): 769-773.

Lima, M. I., M. E. Fonseca, R. Flores y E. W. Kitajima (1994). "Detection of avocado sunblotch viroid in chloroplasts of avocado leaves by in situ hybridization." Archives of Virology 138(3-4): 385-390.

Lin, B., Z. Wang, A. P. Malanoski, E. A. O'Grady, C. F. Wimpee, V. Vuddhakul, N. Alves Jr, F. L. Thompson, B. Gomez-Gil y G. J. Vora (2010). "Comparative genomic analyses identify the Vibrio harveyi genome sequenced strains BAA1116 and HY01 as Vibrio campbellii." Environmental Microbiology Reports 2(1): 81-89.

Lindbo, J. A., L. Silva-Rosales, W. M. Proebsting y W. G. Dougherty (1993). "Induction of a Highly Specific Antiviral State in Transgenic Plants: Implications for Regulation of Gene Expression and Virus Resistance." Plant Cell 5(12): 17491759.

Lippman, Z. y R. Martienssen (2004). "The role of RNA interference in heterochromatic silencing." Nature 431(7006): 364-370.

Liu, C., F. Lu, X. Cui y X. Cao (2010). "Histone methylation in higher plants." Annual Review of Plant Biology 61: 395-420.

Liu, Q., Y. Feng y Z. Zhu (2009). "Dicer-like (DCL) proteins in plants." Functional \& Integrative Genomics 9(3): 277-286.

Lu, C., S. S. Tej, S. Luo, C. D. Haudenschild, B. C. Meyers y P. J. Green (2005). "Elucidation of the small RNA component of the transcriptome." Science 309(5740): 1567-1569.

Lu, R., I. Malcuit, P. Moffett, M. T. Ruiz, J. Peart, A. J. Wu, J. P. Rathjen, A. Bendahmane, L. Day y D. C. Baulcombe (2003). "High throughput virus-induced gene silencing implicates heat shock protein 90 in plant disease resistance." EMBO Journal 22(21): 5690-5699.

Luo, Z. y Z. Chen (2007). "Improperly terminated, unpolyadenylated mRNA of sense transgenes is targeted by RDR6-mediated RNA silencing in Arabidopsis." Plant Cell 19(3): 943-958.

Llave, C. (2010). "Virus-derived small interfering RNAs at the core of plant-virus interactions." Trends in Plant Science 15(12): 701-707.

Llave, C., K. D. Kasschau y J. C. Carrington (2000). "Virus-encoded suppressor of posttranscriptional gene silencing targets a maintenance step in the silencing 
pathway." Proceedings of the National Academy of Sciences USA 97(24): 1340113406.

Llave, C., Z. Xie, K. D. Kasschau y J. C. Carrington (2002). "Cleavage of Scarecrowlike mRNA targets directed by a class of Arabidopsis miRNA." Science 297(5589): 2053-2056.

Ma, Z., C. Coruh y M. J. Axtell (2010). “Arabidopsis lyrata Small RNAs: Transient MIRNA and Small Interfering RNA Loci within the Arabidopsis Genus." Plant Cell; 22(4): 1090-1103.

Macrae, I. J., F. Li, K. Zhou, W. Z. Cande y J. A. Doudna (2006). "Structure of Dicer and mechanistic implications for RNAi." Cold Spring Harbor Symposia on Quantitative Biology 71: 73-80.

Machida, S., N. Yamahata, H. Watanuki, R. A. Owens y T. Sano (2007). "Successive accumulation of two size classes of viroid-specific small RNA in potato spindle tuber viroid-infected tomato plants." Journal of General Virology 88(Pt 12): 34523457.

Makeyev, E. V. y J. M. Grimes (2004). "RNA-dependent RNA polymerases of dsRNA bacteriophages." Virus Research 101(1): 45-55.

Malfitano, M., F. Di Serio, L. Covelli, A. Ragozzino, C. Hernandez y R. Flores (2003). "Peach latent mosaic viroid variants inducing peach calico (extreme chlorosis) contain a characteristic insertion that is responsible for this symptomatology." Virology 313(2): 492-501.

Mallory, A. C., L. Ely, T. H. Smith, R. Marathe, R. Anandalakshmi, M. Fagard, H. Vaucheret, G. Pruss, L. Bowman y V. B. Vance (2001). "HC-Pro suppression of transgene silencing eliminates the small RNAs but not transgene methylation or the mobile signal." Plant Cell 13(3): 571-583.

Mandic, B., M. Al Rwahnih, A. Myrta, G. Gomez y V. Pallas (2008). "Incidence and genetic diversity of Peach latent mosaic viroid and Hop stunt viroid in stone fruits in Serbia." European Journal of Plant Pathology 120(2): 167-176.

Margis, R., A. F. Fusaro, N. A. Smith, S. J. Curtin, J. M. Watson, E. J. Finnegan y P. M. Waterhouse (2006). "The evolution and diversification of Dicers in plants." FEBS Letters 580(10): 2442-2450.

Markarian, N., H. W. Li, S. W. Ding y J. S. Semancik (2004). "RNA silencing as related to viroid induced symptom expression." Archives of Virology 149(2): 397-406.

Martin, R., C. Arenas, J. A. Daros, A. Covarrubias, J. L. Reyes y N. H. Chua (2007). "Characterization of small RNAs derived from Citrus exocortis viroid (CEVd) in infected tomato plants." Virology 367(1): 135-146.

Martínez, G., L. Donaire, C. Llave, V. Pallás y G. Gómez (2010). “High-throughput sequencing of Hop stunt viroid-derived small RNAs from cucumber leaves and phloem”. Molecular Plant Pathology 11: 347-359. 
Martínez, G., J. Forment, C. Llave, V. Pallás y G. Gómez (2011). "High-throughput sequencing, characterization and detection of new and conserved cucumber miRNAs". PLoS One 6(5).e19523

Martinez G., Pallas V y Gomez G (2008). "Analysis of symptoms developed in Nicotiana benthamiana plants expressing dimeric forms of Hop stunt viroid". Journal of Plant Pathology 90: 121-124.

Martinez de Alba, A. E., R. Flores y C. Hernandez (2002). "Two chloroplastic viroids induce the accumulation of small RNAs associated with posttranscriptional gene silencing." Journal of Virology 76(24): 13094-13096.

Matousek, J., P. Kozlova, L. Orctova, A. Schmitz, K. Pesina, O. Bannach, N. Diermann, G. Steger y D. Riesner (2007). "Accumulation of viroid-specific small RNAs and increase in nucleolytic activities linked to viroid-caused pathogenesis." Biological Chemistry 388(1): 1-13.

Maule, A., V. Leh y C. Lederer (2002). "The dialogue between viruses and hosts in compatible interactions." Current Opinion in Plant Biology 5(4): 279-284.

Mi, S., T. Cai, Y. Hu, Y. Chen, E. Hodges, F. Ni, L. Wu, S. Li, H. Zhou, C. Long, S. Chen, G. J. Hannon y Y. Qi (2008). "Sorting of small RNAs into Arabidopsis argonaute complexes is directed by the 5' terminal nucleotide." Cell 133(1): 116127.

Mlotshwa, S., G. J. Pruss, A. Peragine, M. W. Endres, J. Li, X. Chen, R. S. Poethig, L. H. Bowman y V. Vance (2008). "DICER-LIKE2 plays a primary role in transitive silencing of transgenes in Arabidopsis." PLoS ONE 3(3): e1755.

Mlotshwa, S., O. Voinnet, M. F. Mette, M. Matzke, H. Vaucheret, S. W. Ding, G. Pruss y V. B. Vance (2002). "RNA silencing and the mobile silencing signal." Plant Cell 14 Suppl: S289-301.

Mohamed, N. A. y W. Thomas (1980). "Viroid-like properties of an RNA species associated with the sunblotch disease of avocados." Journal of General Virology 46(JAN): 157-167.

Moissiard, G., E. A. Parizotto, C. Himber y O. Voinnet (2007). "Transitivity in Arabidopsis can be primed, requires the redundant action of the antiviral Dicerlike 4 and Dicer-like 2, and is compromised by viral-encoded suppressor proteins." RNA 13(8): 1268-1278.

Moissiard, G. y O. Voinnet (2006). "RNA silencing of host transcripts by cauliflower mosaic virus requires coordinated action of the four Arabidopsis Dicer-like proteins." Proceedings of the National Academy of Sciences USA 103(51): 1959319598.

Molnar, A., T. Csorba, L. Lakatos, E. Varallyay, C. Lacomme y J. Burgyan (2005). "Plant virus-derived small interfering RNAs originate predominantly from highly structured single-stranded viral RNAs." Journal of Virology 79(12): 7812-7818. 
Molnar, A., C. W. Melnyk, A. Bassett, T. J. Hardcastle, R. Dunn y D. C. Baulcombe (2010). "Small silencing RNAs in plants are mobile and direct epigenetic modification in recipient cells." Science 328(5980): 872-875.

Mourrain, P., C. Beclin, T. Elmayan, F. Feuerbach, C. Godon, J. B. Morel, D. Jouette, A. M. Lacombe, S. Nikic, N. Picault, K. Remoue, M. Sanial, T. A. Vo y H. Vaucheret (2000). "Arabidopsis SGS2 and SGS3 genes are required for posttranscriptional gene silencing and natural virus resistance." Cell 101(5): 533542.

Moxon, S., F. Schwach, T. Dalmay, D. Maclean, D. J. Studholme y V. Moulton (2008). "A toolkit for analysing large-scale plant small RNA datasets." Bioinformatics 24(19): 2252-2253.

Muller, B. y U. Grossniklaus (2010). "Model organisms--A historical perspective." Journal of Proteomics 73(11): 2054-2063.

Navarro, B. y R. Flores (1997). "Chrysanthemum chlorotic mottle viroid: unusual structural properties of a subgroup of self-cleaving viroids with hammerhead ribozymes." Proceedings of the National Academy of Sciences USA 94(21): 11262-11267.

Navarro, B., V. Pantaleo, A. Gisel, S. Moxon, T. Dalmay, G. Bisztray, F. Di Serio y J. Burgyan (2009). "Deep sequencing of viroid-derived small RNAs from grapevine provides new insights on the role of RNA silencing in plant-viroid interaction." PLoS ONE 4(11): e7686.

Navarro, L., P. Dunoyer, F. Jay, B. Arnold, N. Dharmasiri, M. Estelle, O. Voinnet y J. D. Jones (2006). "A plant miRNA contributes to antibacterial resistance by repressing auxin signaling." Science 312(5772): 436-439.

Onodera, Y., J. R. Haag, T. Ream, P. C. Nunes, O. Pontes y C. S. Pikaard (2005). "Plant nuclear RNA polymerase IV mediates siRNA and DNA methylation-dependent heterochromatin formation." Cell 120(5): 613-622.

Owens, R. A. y R. W. Hammond (2009). "Viroid Pathogenicity: One Process, Many Faces." Viruses-Basel 1(2): 298-316.

Palatnik, J. F., E. Allen, X. Wu, C. Schommer, R. Schwab, J. C. Carrington y D. Weigel (2003). "Control of leaf morphogenesis by microRNAs." Nature 425(6955): 257263.

Palauqui, J. C., T. Elmayan, J. M. Pollien y H. Vaucheret (1997). "Systemic acquired silencing: transgene-specific post-transcriptional silencing is transmitted by grafting from silenced stocks to non-silenced scions." EMBO Journal 16(15): 4738-4745.

Pallás, V., Genovés, A., Sánchez-Pina, MA. y JA. Navarro (2011). "Systemic movement of viruses via the plant phloem". En: Recent Advances in Plant Virology. Ed. Caranta, C., Aranda, MA., Tepfer, M. and JJ. López-Moya. Caister Academic Press, Norfolk. 
Pang, P. P. y E. M. Meyerowitz (1987). "Arabidopsis Thaliana: A Model System for Plant Molecular Biology." Nature Biotechnology 5(11): 1177-1181.

Pant, B. D., A. Buhtz, J. Kehr y W. R. Scheible (2008). "MicroRNA399 is a longdistance signal for the regulation of plant phosphate homeostasis." Plant Journal 53(5): 731-738.

Pantaleo, V., G. Szittya y J. Burgyan (2007). "Molecular bases of viral RNA targeting by viral small interfering RNA-programmed RISC." Journal of Virology 81(8): 3797-3806.

Pantaleo, V., G. Szittya, S. Moxon, L. Miozzi, V. Moulton, T. Dalmay y J. Burgyan (2010). "Identification of grapevine microRNAs and their targets using highthroughput sequencing and degradome analysis." Plant Journal 62(6): 960-976.

Papaefthimiou, I., A. Hamilton, M. Denti, D. Baulcombe, M. Tsagris y M. Tabler (2001). "Replicating potato spindle tuber viroid RNA is accompanied by short RNA fragments that are characteristic of post-transcriptional gene silencing." Nucleic Acids Research 29(11): 2395-2400.

Papp, I., M. F. Mette, W. Aufsatz, L. Daxinger, S. E. Schauer, A. Ray, J. van der Winden, M. Matzke y A. J. Matzke (2003). "Evidence for nuclear processing of plant micro RNA and short interfering RNA precursors." Plant Physiology 132(3): 1382-1390.

Park, M. Y., G. Wu, A. Gonzalez-Sulser, H. Vaucheret y R. S. Poethig (2005). "Nuclear processing and export of microRNAs in Arabidopsis." Proceedings of the National Academy of Sciences USA 102(10): 3691-3696.

Park, W., J. Li, R. Song, J. Messing y X. Chen (2002). "CARPEL FACTORY, a Dicer homolog, and HEN1, a novel protein, act in microRNA metabolism in Arabidopsis thaliana." Current Biology 12(17): 1484-1495.

Pelchat, M., D. Levesque, J. Ouellet, S. Laurendeau, S. Levesque, J. Lehoux, D. A. Thompson, K. C. Eastwell, L. J. Skrzeczkowski y J. P. Perreault (2000). "Sequencing of peach latent mosaic viroid variants from nine North American peach cultivars shows that this RNA folds into a complex secondary structure." Virology 271(1): 37-45.

Pelissier, T. y M. Wassenegger (2000). "A DNA target of $30 \mathrm{bp}$ is sufficient for RNAdirected DNA methylation." RNA 6(1): 55-65.

Peragine, A., M. Yoshikawa, G. Wu, H. L. Albrecht y R. S. Poethig (2004). "SGS3 and SGS2/SDE1/RDR6 are required for juvenile development and the production of trans-acting siRNAs in Arabidopsis." Genes \& Development 18(19): 2368-2379.

Polivka, H., U. Staub y H. J. Gross (1996). "Variation of viroid profiles in individual grapevine plants: novel grapevine yellow speckle viroid 1 mutants show alterations of hairpin I." Journal of General Virology 77 ( Pt 1): 155-161. 
Pruss, G. J., E. W. Nester y V. Vance (2008). "Infiltration with Agrobacterium tumefaciens induces host defense and development-dependent responses in the infiltrated zone." Molecular Plant-Microbe Interactions 21(12): 1528-1538.

Qi, X., F. S. Bao y Z. Xie (2009). "Small RNA deep sequencing reveals role for Arabidopsis thaliana RNA-dependent RNA polymerases in viral siRNA biogenesis." PLoS ONE 4(3): e4971.

Qi, Y. y B. Ding (2003). "Differential subnuclear localization of RNA strands of opposite polarity derived from an autonomously replicating viroid." Plant Cell 15(11): 2566-2577.

Qu, F., X. Ye, G. Hou, S. Sato, T. E. Clemente y T. J. Morris (2005). "RDR6 has a broad-spectrum but temperature-dependent antiviral defense role in Nicotiana benthamiana." Journal of Virology 79(24): 15209-15217.

Raja, P., B. C. Sanville, R. C. Buchmann y D. M. Bisaro (2008). "Viral genome methylation as an epigenetic defense against geminiviruses." Journal of Virology 82(18): 8997-9007.

Rajagopalan, R., H. Vaucheret, J. Trejo y D. P. Bartel (2006). "A diverse and evolutionarily fluid set of microRNAs in Arabidopsis thaliana." Genes \& Development 20(24): 3407-3425.

Randles, J. W., G. Steger y D. Riesner (1982). "Structural transitions in viroid-like RNAs associated with cadang-cadang disease, velvet tobacco mottle virus, and Solanum nodiflorum mottle virus." Nucleic Acids Research 10(18): 5569-5586.

Reinhart, B. J., F. J. Slack, M. Basson, A. E. Pasquinelli, J. C. Bettinger, A. E. Rougvie, H. R. Horvitz y G. Ruvkun (2000). "The 21-nucleotide let-7 RNA regulates developmental timing in Caenorhabditis elegans." Nature 403(6772): 901-906.

Reinhart, B. J., E. G. Weinstein, M. W. Rhoades, B. Bartel y D. P. Bartel (2002). "MicroRNAs in plants." Genes \& Development 16(13): 1616-1626.

Rhoades, M. W., B. J. Reinhart, L. P. Lim, C. B. Burge, B. Bartel y D. P. Bartel (2002). "Prediction of plant microRNA targets." Cell 110(4): 513-520.

Rivas, F. V., N. H. Tolia, J. J. Song, J. P. Aragon, J. Liu, G. J. Hannon y L. Joshua-Tor (2005). "Purified Argonaute 2 and an siRNA form recombinant human RISC." Nature Structural \& Molecular Biology 12(4): 340-349.

Rodio, M. E., S. Delgado, A. De Stradis, M. D. Gomez, R. Flores y F. Di Serio (2007). "A viroid RNA with a specific structural motif inhibits chloroplast development." Plant Cell 19(11): 3610-3626.

Rodio, M. E., S. Delgado, R. Flores y F. Di Serio (2006). "Variants of Peach latent mosaic viroid inducing peach calico: uneven distribution in infected plants and requirements of the insertion containing the pathogenicity determinant." Journal of General Virology 87(Pt 1): 231-240.

Ruiz-Ferrer, V. y O. Voinnet (2009). "Roles of plant small RNAs in biotic stress responses." Annual Review of Plant Biology 60: 485-510. 
Sanger, H. L., G. Klotz, D. Riesner, H. J. Gross y A. K. Kleinschmidt (1976). "Viroids are single-stranded covalently closed circular RNA molecules existing as highly base-paired rod-like structures." Proceedings of the National Academy of Sciences USA 73(11): 3852-3856.

Sano, T., Ed. (2003). "Hop stunt viroid in cucumber". En: Viroids. Ed. Hadidi A., Flores R., Randles JW., Semancik JS. CSIRO Publising, Collingwood, 67-70.

Sano, T., T. Candresse, R. W. Hammond, T. O. Diener y R. A. Owens (1992). "Identification of multiple structural domains regulating viroid pathogenicity." Proceedings of the National Academy of Sciences USA 89(21): 10104-10108.

Sano, T., T. Hataya, Y. Terai y E. Shikata (1989). "Hop stunt viroid strains from dapple fruit disease of plum and peach in Japan." Journal of General Virology 70 ( Pt 6): 1311-1319.

Sasaki, M. y E. Shikata (1977). "Some properties of hop stunt disease agent, a viroid." Proceedings of the Japan Academy Series B-Physical and Biological Sciences 53(3): 109-112.

Schiebel, W., B. Haas, S. Marinkovic, A. Klanner y H. L. Sanger (1993). "RNAdirected RNA polymerase from tomato leaves. II. Catalytic in vitro properties." Journal of Biological Chemistry 268(16): 11858-11867.

Schnell, R. J., C. T. Olano y D. N. Kuhn (2001). "Detection of avocado sunblotch viroid variants using fluorescent single-strand conformation polymorphism analysis." Electrophoresis 22(3): 427-432.

Schnolzer, M., B. Haas, K. Raam, H. Hofmann y H. L. Sanger (1985). "Correlation between structure and pathogenicity of potato spindle tuber viroid (PSTV)." EMBO Journal 4(9): 2181-2190.

Schwach, F., F. E. Vaistij, L. Jones y D. C. Baulcombe (2005). "An RNA-dependent RNA polymerase prevents meristem invasion by potato virus $\mathrm{X}$ and is required for the activity but not the production of a systemic silencing signal." Plant Physiology 138(4): 1842-1852.

Schwind, N., M. Zwiebel, A. Itaya, B. Ding, M. B. Wang, G. Krczal y M. Wassenegger (2009). "RNAi-mediated resistance to Potato spindle tuber viroid in transgenic tomato expressing a viroid hairpin RNA construct." Molecular Plant Pathology 10(4): 459-469.

Semancik, J. S., C. N. Roistacher, R. Riverabustamante y N. Duranvila (1988). "Citrus cachexia viroid, a new viroid of citrus- relationship to viroids of the exocortis disease complex." Journal of General Virology 69: 3059-3068.

Semancik, J. S., J. A. Szychowski, A. G. Rakowski y R. H. Symons (1994). "A stable 463 nucleotide variant of citrus exocortis viroid produced by terminal repeats." Journal of General Virology 75 ( Pt 4): 727-732. 
Semancik, J. S., D. Tsuruda, L. Zaner, J. L. Geelen y J. G. Weathers (1976). "Exocortis disease: subcellular distribution of pathogenic (viroid) RNA." Virology 69(2): 669-676.

Semancik, J. S. y L. G. Weathers (1972). "Exocortis disease: evidence for a new species of "infectious" low molecular weight RNA in plants." Nature New Biology 237(77): 242-244.

Senthil, G., H. Liu, V. G. Puram, A. Clark, A. Stromberg y M. M. Goodin (2005). "Specific and common changes in Nicotiana benthamiana gene expression in response to infection by enveloped viruses." Journal of General Virology 86(Pt 9): 2615-2625.

Serra, P., S. Gago y N. Duran-Vila (2008). "A single nucleotide change in Hop stunt viroid modulates citrus cachexia symptoms." Virus Research 138(1-2): 130-134.

Shikata, E. (1990). "New viroids from Japan." Seminars in Virology 1: 107-115.

Shimura, H., V. Pantaleo, T. Ishihara, N. Myojo, J.-i. Inaba, K. Sueda, J. Burgyán y C. Masuta (2011). "A Viral Satellite RNA Induces Yellow Symptoms on Tobacco by Targeting a Gene Involved in Chlorophyll Biosynthesis using the RNA Silencing Machinery." PLoS Pathogens 7(5): e1002021.

Singh, R.P. (2003).”Biology". En: Viroids. Ed. Hadidi A., Flores R., Randles JW., Semancik JS. CSIRO Publising, Collingwood, 67-70.

Slotkin, R. K., M. Vaughn, F. Borges, M. Tanurdzic, J. D. Becker, J. A. Feijo y R. A. Martienssen (2009). "Epigenetic reprogramming and small RNA silencing of transposable elements in pollen." Cell 136(3): 461-472.

Smith, N.A., A.L. Eamens y M.B. Wang (2011). "Viral Small Interfering RNAs Target Host Genes to Mediate Disease Symptoms in Plants." PLoS Pathogens 7(5):e1002022.

Sogo, J. M., T. Koller y T. O. Diener (1973). "Potato spindle tuber viroid. X. Visualization and size determination by electron microscopy." Virology 55(1): 7080.

St-Pierre, P., I. F. Hassen, D. Thompson y J. P. Perreault (2009). "Characterization of the siRNAs associated with peach latent mosaic viroid infection." Virology 383(2): 178-182.

Sunkar, R. y J. K. Zhu (2004). "Novel and stress-regulated microRNAs and other small RNAs from Arabidopsis." Plant Cell 16(8): 2001-2019.

Symons, R. H. (1981). "Avocado sunblotch viroid: primary sequence and proposed secondary structure." Nucleic Acids Research 9(23): 6527-6537.

Szittya, G., A. Molnar, D. Silhavy, C. Hornyik y J. Burgyan (2002). "Short defective interfering RNAs of tombusviruses are not targeted but trigger post-transcriptional gene silencing against their helper virus." Plant Cell 14(2): 359-372. 
Szittya, G., S. Moxon, V. Pantaleo, G. Toth, R. L. Rusholme Pilcher, V. Moulton, J. Burgyan y T. Dalmay (2010). "Structural and functional analysis of viral siRNAs." PLoS Pathogens 6(4): e1000838.

Szittya, G., D. Silhavy, A. Molnar, Z. Havelda, A. Lovas, L. Lakatos, Z. Banfalvi y J. Burgyan (2003). "Low temperature inhibits RNA silencing-mediated defence by the control of siRNA generation." EMBO Journal 22(3): 633-640.

Tabler, M. y M. Tsagris (2004). "Viroids: petite RNA pathogens with distinguished talents." Trends in Plant Science 9(7): 339-348.

Takeda, A., S. Iwasaki, T. Watanabe, M. Utsumi y Y. Watanabe (2008). "The mechanism selecting the guide strand from small RNA duplexes is different among argonaute proteins." Plant and Cell Physiology 49(4): 493-500.

Tolia, N. H. y L. Joshua-Tor (2007). "Slicer and the argonautes." Nature Chemical Biology 3(1): 36-43.

Tomari, Y., C. Matranga, B. Haley, N. Martinez y P. D. Zamore (2004). "A protein sensor for siRNA asymmetry." Science 306(5700): 1377-1380.

Trindade, I., C. Capitao, T. Dalmay, M. P. Fevereiro y D. M. Santos (2010). "miR398 and miR408 are up-regulated in response to water deficit in Medicago truncatula." Planta 231(3): 705-716.

Tsagris, E. M., A. E. Martinez de Alba, M. Gozmanova y K. Kalantidis (2008). "Viroids." Cellular Microbiology 10(11): 2168-2179.

Vaistij, F. E., L. Jones y D. C. Baulcombe (2002). "Spreading of RNA targeting and DNA methylation in RNA silencing requires transcription of the target gene and a putative RNA-dependent RNA polymerase." Plant Cell 14(4): 857-867.

Vance, V. y H. Vaucheret (2001). "RNA silencing in plants--defense and counterdefense." Science 292(5525): 2277-2280.

Vaucheret, H. (2006). "Post-transcriptional small RNA pathways in plants: mechanisms and regulations." Genes \& Development 20(7): 759-771.

Vazquez, F., V. Gasciolli, P. Crete y H. Vaucheret (2004). "The nuclear dsRNA binding protein HYL1 is required for microRNA accumulation and plant development, but not posttranscriptional transgene silencing." Current Biology 14(4): 346-351.

Vazquez, F., H. Vaucheret, R. Rajagopalan, C. Lepers, V. Gasciolli, A. C. Mallory, J. L. Hilbert, D. P. Bartel y P. Crete (2004). "Endogenous trans-acting siRNAs regulate the accumulation of Arabidopsis mRNAs." Molecular Cell 16(1): 69-79.

Visvader, J. E. y R. H. Symons (1985). "Eleven new sequence variants of citrus exocortis viroid and the correlation of sequence with pathogenicity." Nucleic Acids Research 13(8): 2907-2920.

Vogt, U., T. Pelissier, A. Putz, F. Razvi, R. Fischer y M. Wassenegger (2004). "Viroidinduced RNA silencing of GFP-viroid fusion transgenes does not induce extensive spreading of methylation or transitive silencing." Plant Journal 38(1): 107-118. 
Voinnet, O. (2008). "Use, tolerance and avoidance of amplified RNA silencing by plants." Trends in Plant Science 13(7): 317-328.

Voinnet, O. (2009). "Origin, biogenesis, and activity of plant microRNAs." Cell 136(4): 669-687.

Voinnet, O. y D. C. Baulcombe (1997). "Systemic signalling in gene silencing." Nature 389(6651): 553.

Voinnet, O., P. Vain, S. Angell y D. C. Baulcombe (1998). "Systemic spread of sequence-specific transgene RNA degradation in plants is initiated by localized introduction of ectopic promoterless DNA." Cell 95(2): 177-187.

Wang, M. B., X. Y. Bian, L. M. Wu, L. X. Liu, N. A. Smith, D. Isenegger, R. M. Wu, C. Masuta, V. B. Vance, J. M. Watson, A. Rezaian, E. S. Dennis y P. M. Waterhouse (2004). "On the role of RNA silencing in the pathogenicity and evolution of viroids and viral satellites." Proceedings of the National Academy of Sciences USA 101(9): 3275-3280.

Wassenegger, M., S. Heimes y H. L. Sanger (1994). "An infectious viroid RNA replicon evolved from an in vitro-generated non-infectious viroid deletion mutant via a complementary deletion in vivo." EMBO Journal 13(24): 6172-6177.

Wassenegger, M. y G. Krczal (2006). "Nomenclature and functions of RNA-directed RNA polymerases." Trends in Plant Science 11(3): 142-151.

Westerhout, E. M., M. Ooms, M. Vink, A. T. Das y B. Berkhout (2005). "HIV-1 can escape from RNA interference by evolving an alternative structure in its RNA genome." Nucleic Acids Research 33(2): 796-804.

Xie, Z., E. Allen, N. Fahlgren, A. Calamar, S. A. Givan y J. C. Carrington (2005a). "Expression of Arabidopsis MIRNA genes." Plant Physiology 138(4): 2145-2154.

Xie, Z., E. Allen, A. Wilken y J. C. Carrington (2005b). "DICER-LIKE 4 functions in trans-acting small interfering RNA biogenesis and vegetative phase change in Arabidopsis thaliana." Proceedings of the National Academy of Sciences USA 102(36): 12984-12989.

Xie, Z., L. K. Johansen, A. M. Gustafson, K. D. Kasschau, A. D. Lellis, D. Zilberman, S. E. Jacobsen y J. C. Carrington (2004). "Genetic and functional diversification of small RNA pathways in plants." PLoS Biology 2(5): E104.

Xie, Z., K. D. Kasschau y J. C. Carrington (2003). "Negative feedback regulation of Dicer-Like1 in Arabidopsis by microRNA-guided mRNA degradation." Current Biology 13(9): 784-789.

Xie, Z. y X. Qi (2008). "Diverse small RNA-directed silencing pathways in plants." Biochimica et Biophysica Acta 1779(11): 720-724.

Yekta, S., I. H. Shih y D. P. Bartel (2004). "MicroRNA-directed cleavage of HOXB8 mRNA." Science 304(5670): 594-596. 
Yoshikawa, M., A. Peragine, M. Y. Park y R. S. Poethig (2005). "A pathway for the biogenesis of trans-acting siRNAs in Arabidopsis." Genes \& Development 19(18): 2164-2175.

Yu, B., L. Bi, B. Zheng, L. Ji, D. Chevalier, M. Agarwal, V. Ramachandran, W. Li, T. Lagrange, J. C. Walker y X. Chen (2008). "The FHA domain proteins DAWDLE in Arabidopsis and SNIP1 in humans act in small RNA biogenesis." Proceedings of the National Academy of Sciences USA 105(29): 10073-10078.

Yu, B., Z. Yang, J. Li, S. Minakhina, M. Yang, R. W. Padgett, R. Steward y X. Chen (2005). "Methylation as a crucial step in plant microRNA biogenesis." Science 307(5711): 932-935.

Zaitlin, M., C. L. Niblett, E. Dickson y R. B. Goldberg (1980). "Tomato DNA contains no detectable regions complementary to potato spindle tuber viroid as assayed by solution and filter hybridization." Virology 104(1): 1-9.

Zhang, B., X. Pan, G. P. Cobb y T. A. Anderson (2006). "Plant microRNA: a small regulatory molecule with big impact." Developmental Biology 289(1): 3-16.

Zhang, B., X. Pan y E. J. Stellwag (2008). "Identification of soybean microRNAs and their targets." Planta 229(1): 161-182.

Zhang, X., Y. R. Yuan, Y. Pei, S. S. Lin, T. Tuschl, D. J. Patel y N. H. Chua (2006). "Cucumber mosaic virus-encoded 2b suppressor inhibits Arabidopsis Argonaute1 cleavage activity to counter plant defense." Genes \& Development 20(23): 32553268.

Zhang, Y., S. Dorey, M. Swiderski y J. D. Jones (2004). "Expression of RPS4 in tobacco induces an AvrRps4-independent HR that requires EDS1, SGT1 and HSP90." Plant Journal 40(2): 213-224.

Zhang, Z., J. Yu, D. Li, F. Liu, X. Zhou, T. Wang, Y. Ling y Z. Su (2010). "PMRD: plant microRNA database." Nucleic Acids Research 38(Database issue): D806813.

Zhao, B., R. Liang, L. Ge, W. Li, H. Xiao, H. Lin, K. Ruan y Y. Jin (2007). "Identification of drought-induced microRNAs in rice." Biochemical and Biophysical Research Communications 354(2): 585-590.

Zhong, X., N. Leontis, S. Qian, A. Itaya, Y. Qi, K. Boris-Lawrie y B. Ding (2006). "Tertiary structural and functional analyses of a viroid RNA motif by isostericity matrix and mutagenesis reveal its essential role in replication." Journal of Virology 80(17): 8566-8581.

Zhou, L., Y. Liu, Z. Liu, D. Kong, M. Duan y L. Luo (2010). "Genome-wide identification and analysis of drought-responsive microRNAs in Oryza sativa." Journal of Experimental Botany 61(15): 4157-4168.

Zhou, X., G. Wang y W. Zhang (2007). "UV-B responsive microRNA genes in Arabidopsis thaliana." Molecular Systems Biology 3: 103. 
Zhu, Y., Y. Qi, Y. Xun, R. Owens y B. Ding (2002). "Movement of potato spindle tuber viroid reveals regulatory points of phloem-mediated RNA traffic." Plant Physiology 130(1): 138-146. 
